\title{
Louisiana Barrier Island Comprehensive Monitoring (BICM) Program Summary Report: Data and Analyses 2006 through 2010
}

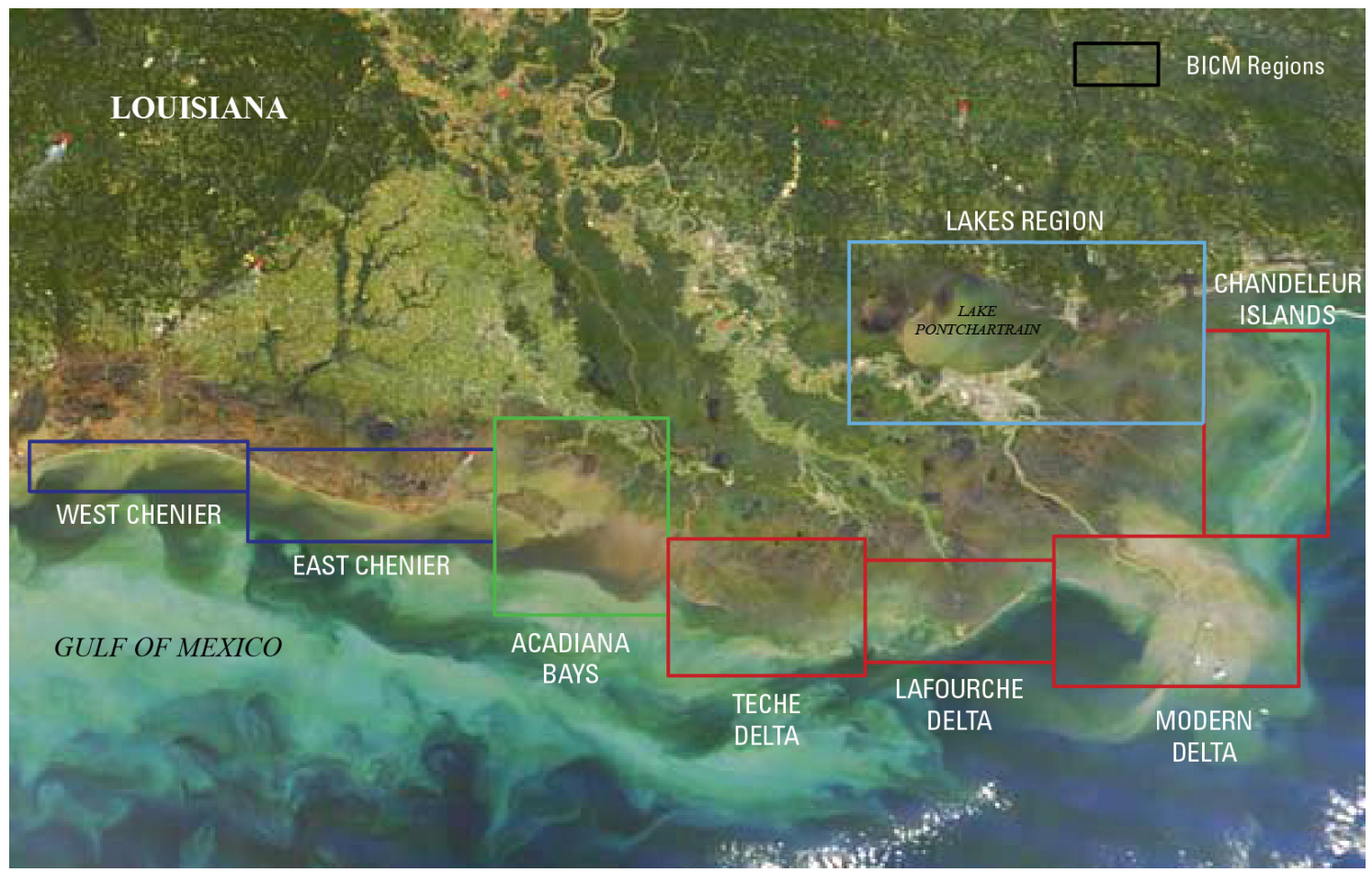

By Jack L. Kindinger, Noreen A. Buster, James G. Flocks, Julie C. Bernier, and Mark A. Kulp

Open-File Report 2013-1083

U.S. Department of the Interior

U.S. Geological Survey 
Cover: The eight BICM study regions in Louisiana displayed with a 2008 NASA Terra satellite image after Hurricane Ike passed inland. 


\section{Louisiana Barrier Island Comprehensive Monitoring (BICM) Program Summary Report: Data and Analyses 2006 through 2010}

By Jack L. Kindinger, Noreen A. Buster, James G. Flocks, Julie C. Bernier, and Mark A. Kulp

Open-File Report 2013-1083

U.S. Department of the Interior

U.S. Geological Survey 


\section{U.S. Department of the Interior}

Ken Salazar, Secretary

\section{U.S. Geological Survey \\ Suzette M. Kimball, Acting Director}

U.S. Geological Survey, Reston, Virginia 2013

For product and ordering information:

World Wide Web: http://Www.usgs.gov/pubprod

Telephone: 1-888-ASK-USGS

For more information on the USGS - the Federal source for science about the Earth, its natural and living resources, natural hazards, and the environment:

World Wide Web: http://WwW.usgs.gov

Telephone: 1-888-ASK-USGS

Suggested citation:

Kindinger, J.L., Buster, N.A., Flocks, J.G., Bernier, J.C., and Kulp, M.A., 2013, Louisiana Barrier Island Comprehensive Monitoring (BICM) Program Summary Report: Data and Analyses 2006 through 2010: U.S. Geological Survey Open-File Report 2013-1083, 86 p.

Any use of trade, product, or firm names is for descriptive purposes only and does not imply endorsement by the U.S. Government.

Although this report is in the public domain, permission must be secured from the individual copyright owners to reproduce any copyrighted material contained within this report. 


\section{Contents}

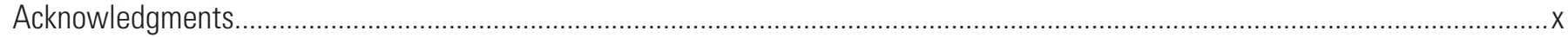

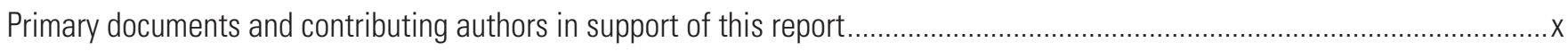

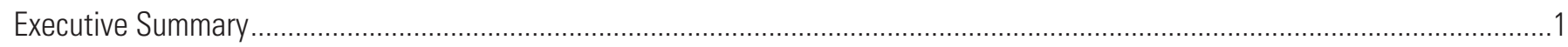

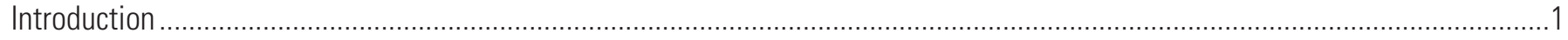

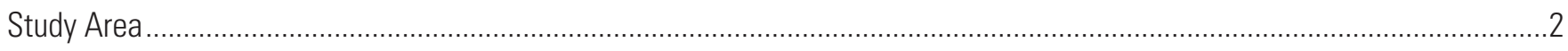

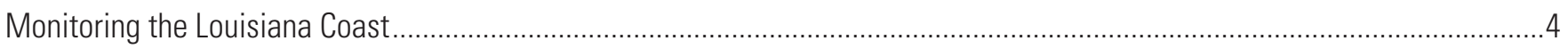

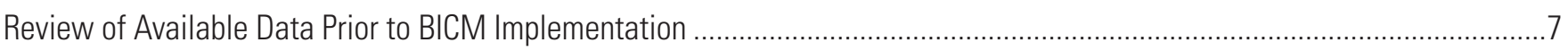

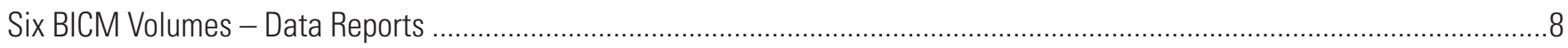

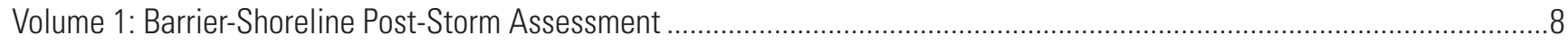

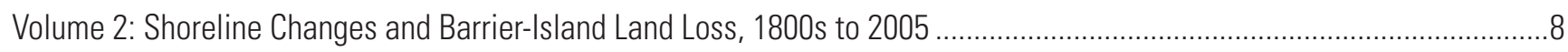

Volume 3: Bathymetry and Historical Seafloor Change, 1869-2007 ........................................................................

Volume 4: Accuracy of EAARL Lidar Ground Elevations Using a Bare-Earth Algorithm in Marsh and Beach Grasses on the

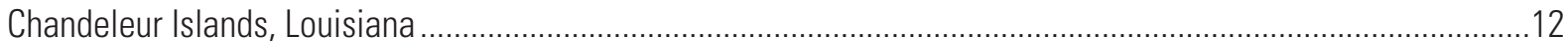

Volume 5: Chenier Plain, South-Central Louisiana, and Chandeleur Islands Habitat Mapping and Change Analysis 1996 to

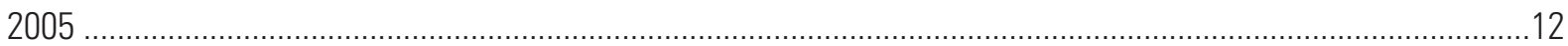

Volume 6: Characterization of Louisiana Coastal Sediment Samples: Back-Barrier through Offshore Samples of the Chenier Plain, South-Central Barrier-Island Systems, and Chandeleur Islands .........................................................12

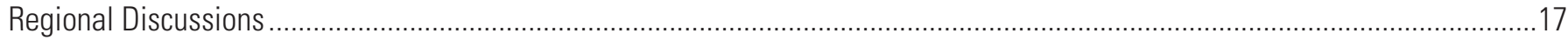

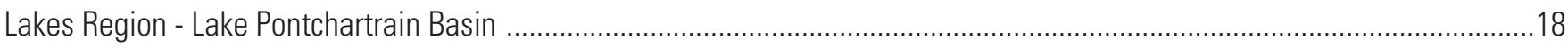

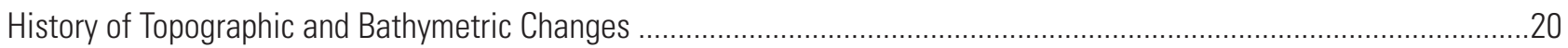

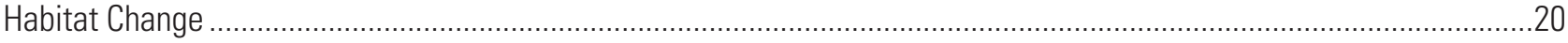

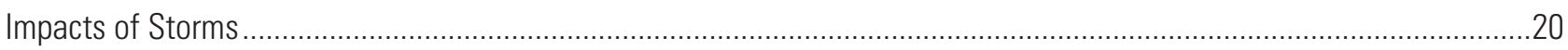

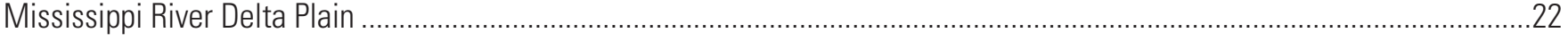

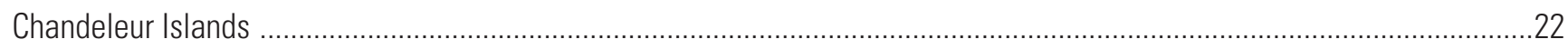

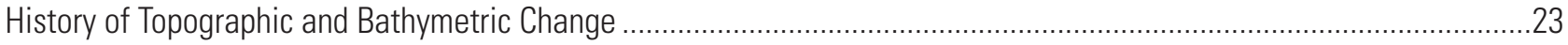

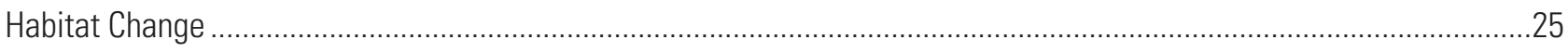

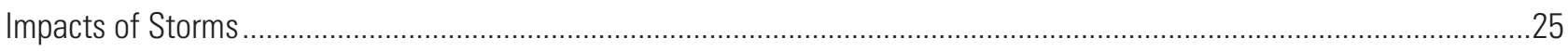

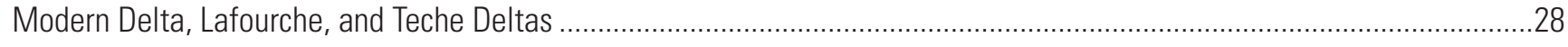

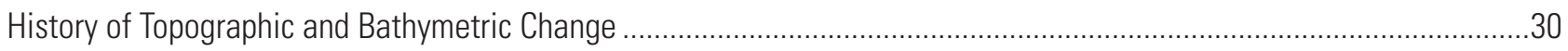

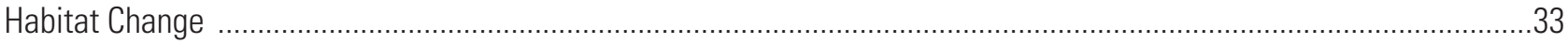

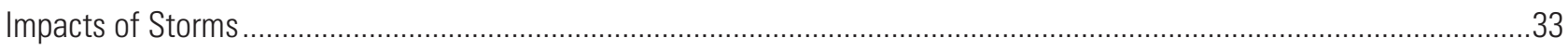

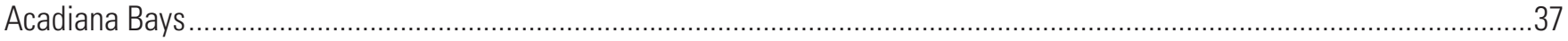

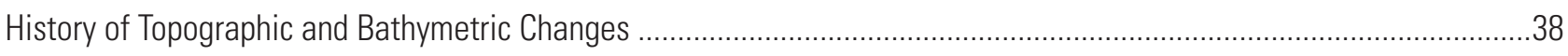

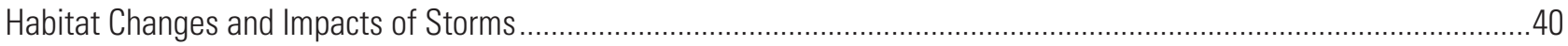

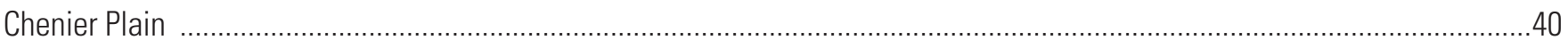

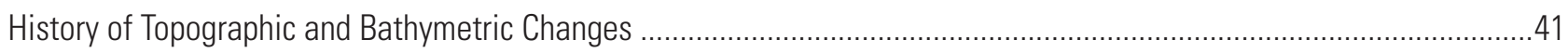

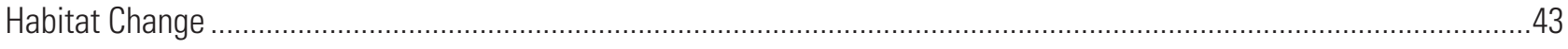

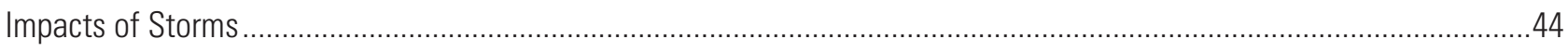

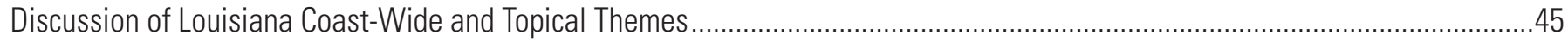


THEME 1: Barrier-Shoreline Evolution in a Regime of Rapid Relative Sea-Level Rise and Interior-Wetland Loss

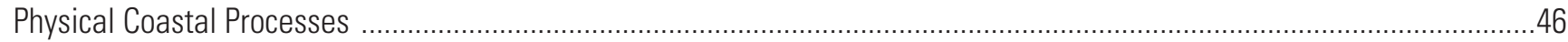

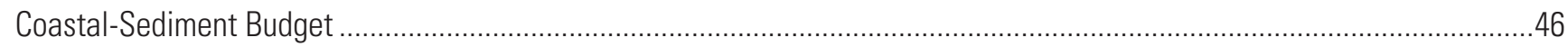

THEME 2: Hurricane Impact to the Chandeleur Islands during the Period 1855 to 2005 and the Likelihood of Island Recovery.47

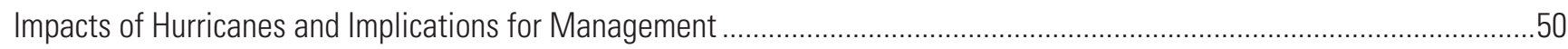

THEME 3: Impact of Tropical Storms on Barrier-Shoreline Elevations and the Response of Island Renourishment to Storms ...54

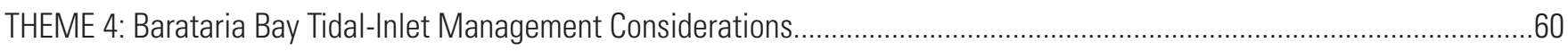

Methods 61

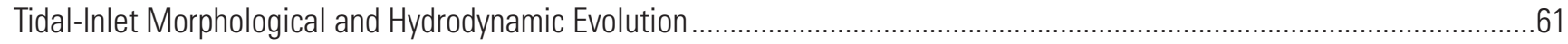

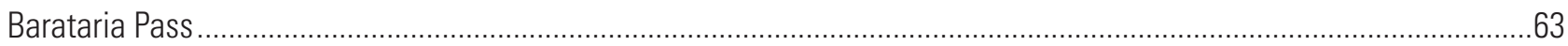

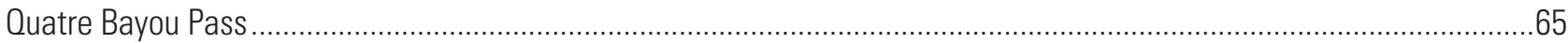

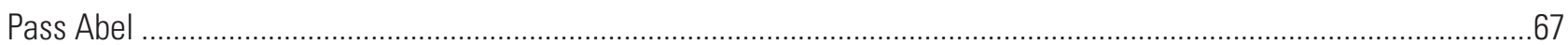

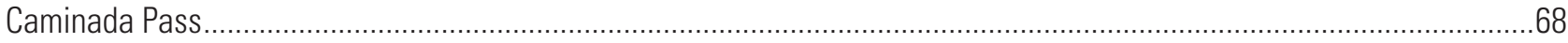

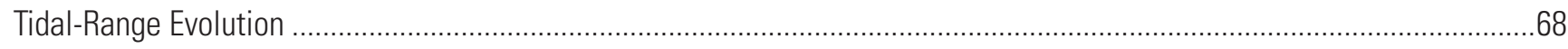

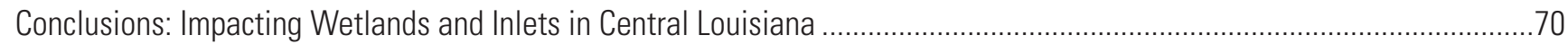

THEME 5: Habitat Changes Related to Long-Term Relative Sea-Level-Driven Erosion and Short-Term Storm-Driven Erosion.....71

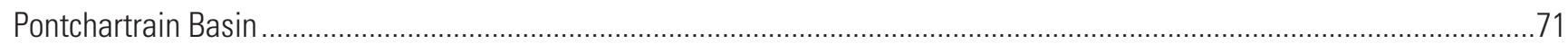

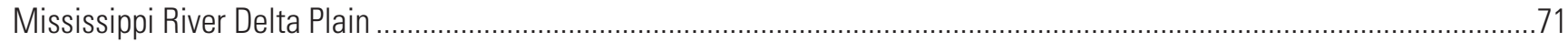

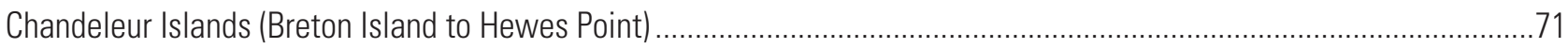

Modern Delta (Chaland Headland, Bay Joe Wise, Shell Island, Scofield, and Sandy Point) .........................................71

Lafourche Delta (Timbalier Island, East Timbalier Island, the Caminada Headland, Grand Isle, Grand Terre Island, and East

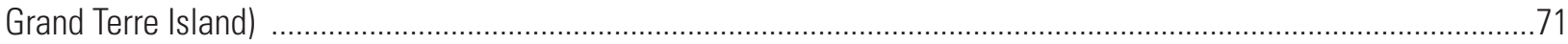

Teche Delta (Isles Dernieres Chain from Raccoon Point to Wine Island Pass) ............................................................72

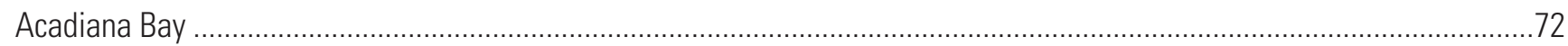

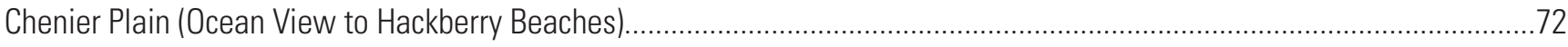

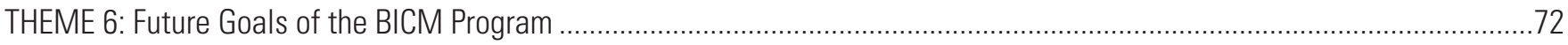

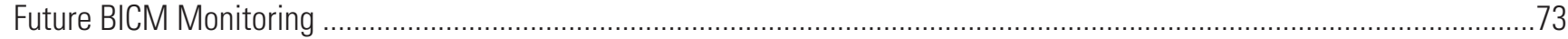

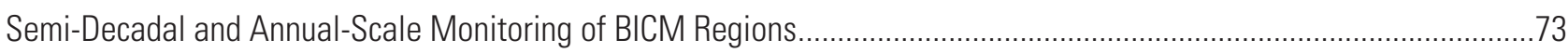

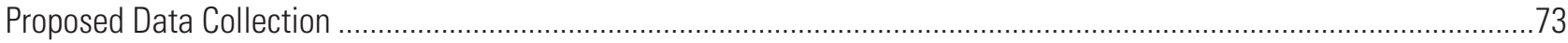

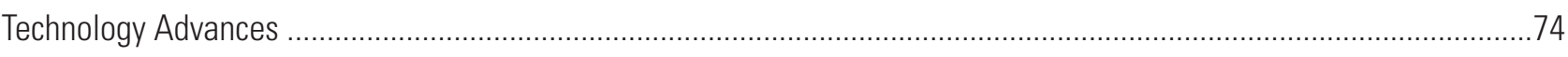

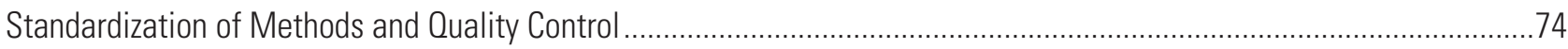

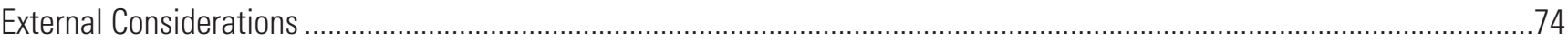

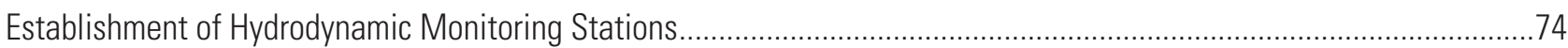

Development of Barrier-Island Value Assessment Model .....................................................................................

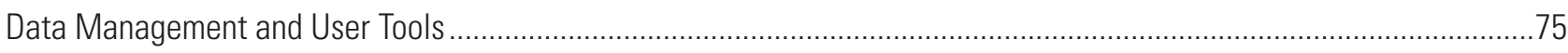

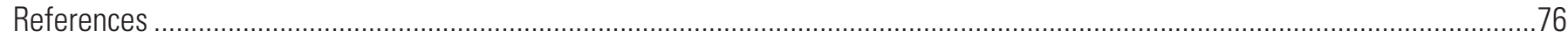




\section{Figures}

1. The original four coastal Louisiana shoreline regions based on geologic and physiographic setting (Pontchartrain Basin, Mississippi River Delta Plain, Acadiana Bays, and Chenier Plain) with the eight regions used in BICM analyses (the Lakes Region; Chandeleur Islands; Modern, Lafourche, and Teche Deltas; Acadiana Bays; and the eastern and western Chenier Plain)

2. Data-coverage map for each BICM task: barrier-shoreline post-storm assessment, historical shoreline changes, bathymetric and historical seafloor change, lidar surveys for the Louisiana coast, habitat mapping and change analysis, and characterization of coastal surface-sediment samples

3. Example of Volume 1 Barrier-Shoreline Post-Storm Assessment aerial time-series photo pair of Trinity Island for 2005 and $2007 . . .9$

4. Location map depicting the 80 different reaches of shoreline designated during the BICM program to analyze shoreline change for coastal Louisiana.

5. Historical shoreline positions for the Isle Dernieres from 1887 to 2005 with change maps for time periods: 1887-1934, 19341996, 1996-2004, and 2004-2005.

6. Seafloor-change maps created by digitizing historical bathymetry and collecting data during the BICM program for the northern Chandeleur Islands.

7. A time-series depiction of lidar data collected for the Chandeleur Islands showing land loss along the island chain over an approximately 5-year period from October 2002, to September 2005-2 days post-Hurricane Katrina, and to June 2007-22 months post-Hurricane Katrina.

8. Habitat-change map (1996 to 2005) for Timbalier Island, Lafourche Delta.

9. Map showing locations and grain sizes of surficial-sediment samples collected for the BICM program along one stretch of the modern Mississippi River Delta.

10. Distribution and chronology of Holocene Mississippi River delta complexes.

11. Map of the Pontchartrain Basin showing the river basins that drain into Lakes Pontchartrain, Maurepas, and Borgne................18

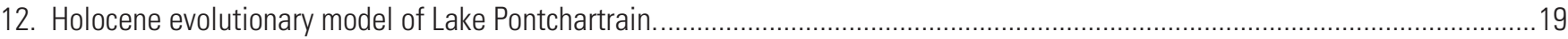

13. Map showing shoreline change around Lake Pontchartrain, Lake Borgne, and Lake Maurepaus between 1855 and 2005. .........21

14. Aerial photos taken of the coastline within the Pontchartrain Lake Basin in 2006 as part of the BICM program.......................21

15. Bathymetric map (2006-2007) using BICM data collected in the nearshore waters around the Breton National Wildlife

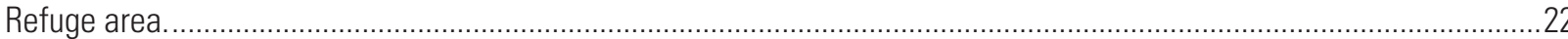

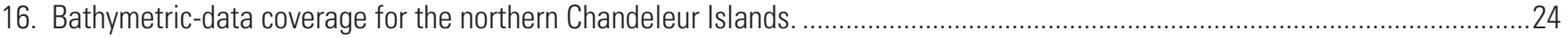

17. Sediment isopach of Hewes Point terminal spit; deposit (purple and red) is approximately $27 \mathrm{~km}^{2}\left(10 \mathrm{mi}^{2}\right), 8 \mathrm{~m}(26.3 \mathrm{ft})$ thick, and is composed of 97 percent well-sorted fine sand.

18A. Habitat-change map of Breton Island (1998 to 2002). .26

18B. Habitat-change map of the Chandeleur Islands (2004 to 2005) — note the large areas of habitat change to water after

19. Cumulative percentage histograms of habitat change in analysis areas during the four analyses time periods...........................28

20. Oblique aerial-photo time series of a portion of the Chandeleur Islands.

21. Bathymetry collected during the BICM project in 2006 along Caminada Headland, Grand Isle, and Grand Terre. Barrier extents are indicated by green with shorelines derived from thematic classifications produced from image datasets and GIS editing. 
22. Seafloor-change map of the Raccoon Point to Sandy Point area from the 1880 s to 2005.

23. Historical (from 1884 to 2005) shoreline-change time series of Timbalier Island, Caminada Headland, and Grand Isle using shoreline data compiled from BICM Volume 2.

24. Habitat-change classification for Whiskey Island, Teche Delta between the years 1996 and 2005 showing that during the passage of Hurricanes Katrina and Rita, significant washover occurred on Whiskey Island, increasing the acreages of beach and intertidal-flat habitat.

25. Cumulative percentage histograms of habitat change in analysis areas during the four analyses time periods........ .35

26. Caminada Headland shoreface seafloor-change map, 2005 to 2006.

27. Example of Volume 1 Barrier-Shoreline Post-Storm Assessment aerial time-series photo pair of Elmers Island for 2005 and 2007.

28. Vibracore transect across Atchafalaya Bay, to the west of the present navigation channel. The cross section reflects the transition from a brackish-marsh environment into estuarine, or bay, and then modern fluvial delta.

29. Shoreline-change map (1800s to 2005) of the Morgan City quadrangle. USGS Quadrangle in the Acadiana Bays region analyzed during BICM project

30. Oblique aerial photos of the Atchafalya Delta, 2006, and Marsh Island, 2005, shorelines taken as part of the BICM program. ...39

31. Historical (1855 to 2005) shoreline-change rates in meters per year along the Chenier Plain coastline.

32. Western Chenier shoreline and 2007 bathymetric map using BICM-program data.

33. Western Chenier historical seafloor-change map from the 1880s to 1920s using digitized H- and T-sheets from the U.S. Coastal and Geodetic Survey and seafloor change methods and uncertainty analysis.

34. Western Chenier historical seafloor-change map from the 1920s to 2007 using digitized H- and T-sheets from the U.S. Coast and Geodetic Survey and seafloor change methods and uncertainty analysis.

35. BICM habitat-change map (1998 to 2002) for Holly Beach along the western Chenier Plain. 43

36. Oblique aerial time-series photo pair of Johnson's Bayou shoreline for the years 2005 and 2006......................................44

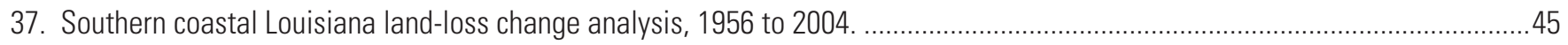

38. Location map showing the Chandeleur Islands relative to other physiographic features. .........................................................47

39. Shoreline-retreat and land-area change for the Chandeleur Islands between 1855 and 2005 ..............................................48

40. View to the south of the seafloor surfaces of the Chandeleur Islands of the 1870s versus those of 2006................................50

41. Maps of the Chandeleur Islands before and after Hurricane Katrina (August 2005) based on lidar data. ..................................51

42. Changes of the shoreline and width of the Chandeleur Islands from lidar surveys before Hurricane Katrina (August 2005), 2

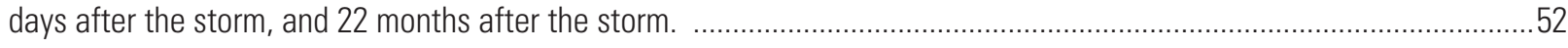

43. Conceptual model demonstrating how a barrier-island management-restoration approach may employ natural physical

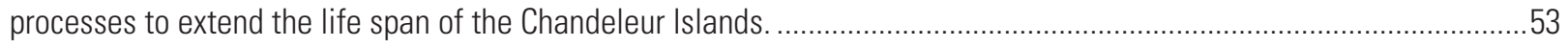

44. Hurricane and tropical storm tracks that impacted the Louisiana coast over the 50-year time period between 1957 and 2008 ...55

45. Erosion of a barrier island is a function of elevation compared to total water run-up, for example, surge+setup+runup on the beach.

46. Peak elevations (Dhigh) determined every $20 \mathrm{~m}(67 \mathrm{ft}$ ) along the length of the Chandeleur Islands using lidar data processed for first return. 
47. Changes to a $2.5-\mathrm{km}(1.6-\mathrm{mi})$ reach of the Chandeleur Islands showing persistent erosion and landward retreat during the 22 months after landfall by Hurricane Katrina (modified from Sallenger and others, 2009).

48. Bare-earth peak elevations (Dhigh), maximum-of-the-maximum storm-surge elevations for different categories ("cat") of hurricanes, and storm surge for Hurricane Katrina computed by using the Sea, Lake, and Overland Surges from Hurricanes (SLOSH) model. (A) 2 days after. (B) 22 months after. (C) Change in Dhigh between 2 days after and 22 months after (Sallenger and others, 2009).

49. Types of erosional and depositional features produced by extreme storms include (A) dune erosion, (B) channel incision, (C) washout, (D) washover terrace, (E) perched fan, (F) sheetwash lineations (Morton and Sallenger, 2003).

50. Hydrodynamic instrument deployment locations and acoustic Doppler current profiler (ADCP) survey tracklines (Howes, 2009).. 60

51. (A) High resolution tidal inlet cross sections from single beam soundings (Howes, 2009) (* denotes transects across the inlets were taken along the same line each, with the exception of Quatre Bayou, where they were offset by 50 meters). (B) Barataria Pass shows an increase in inlet hydraulic radius with increased cross-sectional area compared to the other three passes. It is also the only inlet that did not develop an inlet platform even with increased cross-sectional area (Howes, 2009)

52. Graph showing the relation between peak ebb discharge and tidal range for the four inlets (Barataria Pass, Quatre Bayou, Caminada Pass, and Pass Abel

53. Graph showing inlet cross-sectional area since 1888

54. The morphological evolution of Barataria Pass, including (A) the extension of the inlet channel as defined by the $5 \mathrm{~m}$ contour, (B) the inlet throat defined as greater than $10 \mathrm{~m}$ deep, (C) cross sections across the inlet throat, and (D) the change in hydraulic and dynamic radius (dynamic radius is a measure that weights the depth to the power of $5 / 3$ ); the dynamicradius measure shows the same general trend as hydraulic radius (Howes, 2009)

55. Morphological evolution at Quatre Bayou Pass, including (A) the extension of the inlet channel, (B) the inlet throat defined as greater than $10 \mathrm{~m}(32.8 \mathrm{ft})$ deep, (C) cross sections across the inlet throat, and (D) the change in hydraulic and dynamic radius.

56. Morphological evolution at Pass Abel, including (A) the extension of the inlet channel, (B) there is no panel for $B$ because the inlet throat was defined as greater than $10 \mathrm{~m}$, and this inlet did not achieve that depth, (C) cross sections across the inlet throat, and (D) the change in hydraulic and dynamic radius.

57. Morphologic evolution at Caminada Pass, including (A) the extension of the inlet channel, (B) there is no panel for $B$ because the inlet throat was defined as greater than $10 \mathrm{~m}$, and this inlet did not achieve that depth, (C) cross sections across the inlet throat, and (D) the change in hydraulic and dynamic radius.

58. (A) Three complete cycles of the 18.6-year nodal tidal cycle. (B) The residual tidal signal after the 18.6-year cycle is removed, showing an increase in tidal range over approximately the past 50 years; the rate change increased between 1951 and the early 1970s (Howes, 2009)

59. (A) Relative sea-level rise at Grand Isle, 1947-2006. (B) Hydraulic radius at Barataria Pass (blue points) and the increase in annual tidal range at Grand Isle relative to tidal range in 1951, as shown in 59 (Howes, 2009). 


\section{Tables}

Table 1. Locations and amount of 2006-2010 BICM data collected as numbers of photos, images, mosaics, line-kilometers, minutes of video, and number of samples collected/ analyzed by scientists. 


\section{Conversion Factors}

\begin{tabular}{lll}
\hline \multicolumn{1}{c}{ Multiply } & \multicolumn{1}{c}{ By } & \multicolumn{1}{c}{ To obtain } \\
\hline inch (in.) & \multicolumn{2}{c}{ Length } \\
inch (in.) & 2.54 & centimeter $(\mathrm{cm})$ \\
foot (ft) & 25.4 & millimeter $(\mathrm{mm})$ \\
mile (mi) & 0.3048 & meter $(\mathrm{m})$ \\
mile, nautical (nmi) & 1.609 & kilometer $(\mathrm{km})$ \\
\hline & 1.852 & kilometer $(\mathrm{km})$ \\
\hline acre & \multicolumn{1}{c}{ Area } \\
acre & 0.4047 & hectare (ha) \\
square mile $\left(\mathrm{mi}^{2}\right)$ & 0.004047 & square kilometer $\left(\mathrm{km}^{2}\right)$ \\
square mile $\left(\mathrm{mi}^{2}\right)$ & 259.0 & hectare (ha) \\
& 2.590 & square kilometer $\left(\mathrm{km}^{2}\right)$ \\
\hline
\end{tabular}




\title{
Acknowledgments
}

This report is the cumulative effort of more than 50 contributors who collected and processed data, conducted analyses and interpretations, and wrote data reports. We could not have completed this report without the managerial support and funding from Alyssa Dausman and Jess Weaver of the U.S. Geological Survey Southeast Region and Richard Poore of the U.S. Geological Survey St. Petersburg Coastal and Marine Science Center. We appreciate the invaluable discussions about report approach and structure with Darin Lee, Syed Khalil, and Richard Raynie of the Coastal Restoration and Protection Authority of Louisiana. We thank Nick Howes for leading the effort to rewrite Theme 4, Dallon Weathers (University of New Orleans) for making data and figures available, and also Betsy Boynton's help with U.S. Geological Survey publication layout and compliance. This report was improved considerably by the comments and suggestions of Syed Khalil, Darin Lee, Barbara Lidz, Kay Naugle, and Abby Sallenger.

\section{Primary documents and contributing authors in support of this report}

\section{Volume1: Barrier Shoreline Post-Storm Assessment}

\author{
Part 1: 2005 Post Hurricanes Katrina and Rita Photography \\ Westphal, K.A. \\ Part 2: 2006/2007 Aerial Survey Photography \\ Westphal, K.A. and Penland S. \\ Part 3: 2005-2007 Photo-Pairs \\ Westphal, K.A. \\ Part 4: Historic Photo-Pairs/Time Series \\ Westphal, K.A. \\ Part 5: 2006/2007 Aerial Video Survey \\ Westphal, K.A., Penland S., and Weathers, D.
}

Volume 2: Shoreline Changes and Barrier Island Land Loss 1800's-2005

Appendix A: Tide Gauge Stations, Locations, and Stage Data

Appendix B: NOAA Coastal Survey Maps Used in Historical Analysis

Appendix C: Area Change Graphs, Change Rate Graphs, 11x17 Maps and Data DVD's and CD's

Martinez, L., O'Brien, S., Bethel, M., Penland, S., and Kulp, M.

Volume 3: Bathymetry and Historical Seafloor Change 1869-2007
Part 1: South-Central Louisiana and Northern Chandeleur Islands, Bathymetry Methods and Uncertainty Analysis

Part 2: South Central Louisiana and Northern Chandeleur Islands, Bathymetry Maps 
Part 3: Southern Chandeleur Islands and Western Chenier Beaches, Bathymetry Maps Miner M.D., Kulp M., Flocks J., Twichell D., Penland S., Weathers D., Martinez L., Motti J., DeWitt N., Reynolds B.J., Baldwin W., Danforth B., Worley C., Bergeron E., Ferina N., McCarty P., Brown, M., and Torres J.

Part 4: Historical Seafloor Change Analysis

Miner, M., Weathers, D., Kulp, M., and Rafferty, R.

Volume 4: Louisiana Light Detection and Ranging Data (Lidar)

Part 1: Lidar Systems and Data Processing Techniques

Hansen, M. and Howd, P.

Part 2: Lidar Flight Path Maps

Morgan, K.L.M

Part 3: Accuracy of EAARL Lidar Ground Elevations using a Bare-Earth Algorithm in Marsh and Beach Grasses on the Chandeleur Islands, Louisiana

Doran, K., Sallenger, A.H., Jr., Reynolds B.J., and Wright, C.W.

BICM Lidar Team: Sallenger, A.H., Jr., Wright, C.W., Kristy G., Sullivan, C., Howd, P., Doran, K., Morgan, K.L.M., Reynolds B.J., Hansen, M., and DeWitt, N.

Volume 5: Chenier Plain, South-Central Louisiana, and Chandeleur Islands, Habitat Mapping and Change Analysis 1996 to 2005

Part 1: Methods for Habitat Mapping and Change Analysis 1996 to 2005

Part 2: Habitat, Habitat Change, Land Loss, and Mosaic Maps

Part 3: Habitat Class Tables, Habitat Change Tables, and Final Statistics 1996 to 2005

Part 4: Results and Interpretations of the Habitat Mapping and Change Analysis 1996 to 2005

Fearnley, S., Brien, L., Martinez, L., Miner, M., Kulp, M. and Penland, S.

Volume 6: Parts A and B: Characterization of Louisiana Coastal Zone Sediment Samples: Backbarrier through offshore samples of the Chenier Plain, South Central Barrier Island Systems and Chandeleur Islands

A: Kulp, M., Miner, M., Weathers, D., Motti, J., McCarty, P., Brown, M., Labold, J., and Boudreaux, A., B: Flocks J.G., and Taylor, C.

Theme 4 - Barataria Bay Tidal-Inlet Management Considerations

Howes, N.C., Z.J. Hughes, D.M. FitzGerald, and I.Y. Georgiou 
USGS Science Investigations Report 2009-5252: Sand Resources, Regional Geology, and Coastal Processes of the Chandeleur Islands Coastal System: an Evaluation of the Breton National Wildlife Refuge

Lavoie, D., editor

Contributing Authors (Alphabetical):

Baldwin, W., Bohling, C., Brien, L., Doran, K., Fearnley, S., Flocks, J., Georgiou, I. Y. Guy, K., Howd, P., Kulp, M., Martinez, L., Miner, M., Pendleton, E., Penland, S., Rogers, B., Sallenger, A.H., Jr., Sanford, J., Schindler, J. Twichell, D., Weathers, D., Williams, S.J. and Wright, C.W. 


\title{
Louisiana Barrier Island Comprehensive Monitoring (BICM) Program Summary Report: Data and Analyses 2006 through 2010
}

\author{
By Jack L. Kindinger'1, Noreen A. Buster', James G. Flocks'ㄹ, Julie C. Bernier1', and Mark A. Kulp²
}

\section{Executive Summary}

The Barrier Island Comprehensive Monitoring (BICM) program was implemented under the Louisiana Coastal Area Science and Technology (LCA S\&T) office as a component of the System Wide Assessment and Monitoring (SWAMP) program. The BICM project was developed by the State of Louisiana (Coastal Protection Restoration Authority [CPRA], formerly Department of Natural Resources [DNR]) to complement other Louisiana coastal monitoring programs such as the Coastwide Reference Monitoring System-Wetlands (CRMS-Wetlands) and was a collaborative research effort by CPRA, University of New Orleans (UNO), and the U.S. Geological Survey (USGS). The goal of the BICM program was to provide long-term data on the barrier islands of Louisiana that could be used to plan, design, evaluate, and maintain current and future barrier-island restoration projects. The BICM program used both historical and newly acquired (2006 to 2010) data to assess and monitor changes in the aerial and subaqueous extent of islands, habitat types, sediment texture and geotechnical properties, environmental processes, and vegetation composition. BICM datasets included aerial still and video photography (multiple time series) for shoreline positions, habitat mapping, and land loss; light detection and ranging (lidar) surveys for topographic elevations; single-beam and swath bathymetry; and sediment grab samples. Products produced using BICM data and analyses included (but were not limited to) storm-impact assessments, rate of shoreline and bathymetric change, shoreline-erosion and accretion maps, high-resolution elevation maps, coastal-shoreline and barrier-island habitat-classification maps, and coastal surficial-sediment characterization maps.

Discussions in this report summarize the extensive data-collection efforts and present brief interpretive analyses for four coastal Louisiana geographic regions. In addition, several coastal-wide and topical themes were selected that integrate the data and analyses within a broader coastal context: (1) barrier-shoreline evolution driven by rapid relative sea-level rise (RSLR), (2) hurricane impacts to the Chandeleur Islands and likelihood of island recovery, (3) impact of tropical storms on barrier shorelines, (4) Barataria Bay tidal-inlet management, and (5) habitat changes related to RSLR. The final theme addresses potential future goals of the BICM program, including rotational annual to semi-decadal monitoring, proposed new-data collection, how to incorporate technological advances with previous data-collection and monitoring protocols, and standardizing methods and quality-control assessments for continued coastal monitoring and restoration.

\section{Introduction}

The historical conversion of Louisiana's wetlands, cheniers, and barrier islands to open water has been well documented in numerous studies and anecdotal observations (Williams and others, 1992; List and others, 1997; Morton and others, 2004; Georgiou and others, 2005; Penland and others, 2005; Barras and others, 2008; Blum and Roberts, 2009; Fearnley, Miner, Kulp, FitzGerald, Flocks, and others, 2009; Couvillion and others, 2011; Linscombe and Hartley, 2011). The Barrier Island Comprehensive Monitoring (BICM) program (2006 to 2010) was developed to provide baseline and monitoring data to support coastal-management decisions and adaptive-management planning. The BICM program was initiated under the Louisiana Coastal Area Science and Technology (LCA S\&T) office as a component of the System Wide Assessment and Monitoring (SWAMP) program (USACE, 2004), planned by the Coastal Protection and Restoration 
BICM Program Summary Report: Data and Analyses 2006 through 2010

Authority (CPRA, previously Louisiana Department of Natural Resources, LDNR) and implemented by a collaborative research effort by CPRA, University of New Orleans (UNO), and the U.S. Geological Survey (USGS). The BICM program study area encompassed barrier islands and sandy shorelines extending from the Chandeleur Islands west to the Chenier Plain of Louisiana (fig. 1).

Five main objectives were originally identified:

(1) Determine the elevation, longevity, and conservation mass of the barrier islands;

(2) Determine major habitat types and the distribution and quantity of each habitat on the barrier islands over time;

(3) Determine geotechnical properties of sediments on the barrier islands and surrounding waters to access compatibility of the sediment and the sediment-dispersal pattern to evaluate fill performance;

(4) Relate available data on environmental forces that affect the ecology and morphology of the barrier islands to other BICM datasets; and

(5) Determine species composition and diversity of vegetation within major habitat types on the barrier islands.

As the project evolved, six data-collection tasks were designed to address:

(1) Barrier-shoreline post-storm assessment (aerial videography and photography);

(2) Historical shoreline changes and barrier-island land loss;

(3) Bathymetry and historical seafloor change;

(4) Light detection and ranging (lidar) surveys for the Louisiana coast's sandy shorelines and barrier islands;

(5) Habitat mapping and change analysis; and

(6) Characterization of Louisiana coastal surface-sediment samples.

The methods, data, and results for each of these tasks were published in six data volumes that can be found at ftp://ftp.dnr.state.la.us/BICM and are summarized below. The Louisiana coast is a complex system that encompasses highly variable geomorphic and geologic settings. Regional discussions in this report describe the geologic history and processes that have shaped this coast and provide the relevant scientific context to understand and interpret the BICM data. Finally, data that were collected for the BICM program were incorporated into thematic discussions that focus on current scientific themes, such as understanding the impacts of sea-level rise and large-storm events on the coastal system.

\section{Study Area}

The BICM program area encompasses the mainland shoreline of the southern Louisiana coast with special emphasis on the sandy beaches and barrier islands. For this study, the Louisiana coast was divided into four distinct regions based on geologic and physiographic setting: (1) the Pontchartrain Basin, (2) the Mississippi River Delta Plain, (3) the Acadiana Bays, and (4) the Chenier Plain. As the project developed, BICM further subdivided the coastline into eight regions: the Lakes Region; Chandeleur Islands; Modern, Lafourche, and Teche Deltas; Acadiana Bays; and the eastern and western Chenier Plain (fig. 1).

Not all BICM tasks included data collection across every region. Each task had different priorities and areas of concern. For example, shoreline-change analyses and lidar surveys were conducted along the entire coast, whereas bathymetric surveys focused on the barrier islands and sandy shorelines and were restricted to three primary geographical provinces: (1) parts of the eastern and western Chenier Plain; (2) from the western edge of Raccoon Island of the Isles Dernieres to Sandy Point along the Plaquemines Parish shoreline; and (3) the Chandeleur Islands. Aerial photography was 

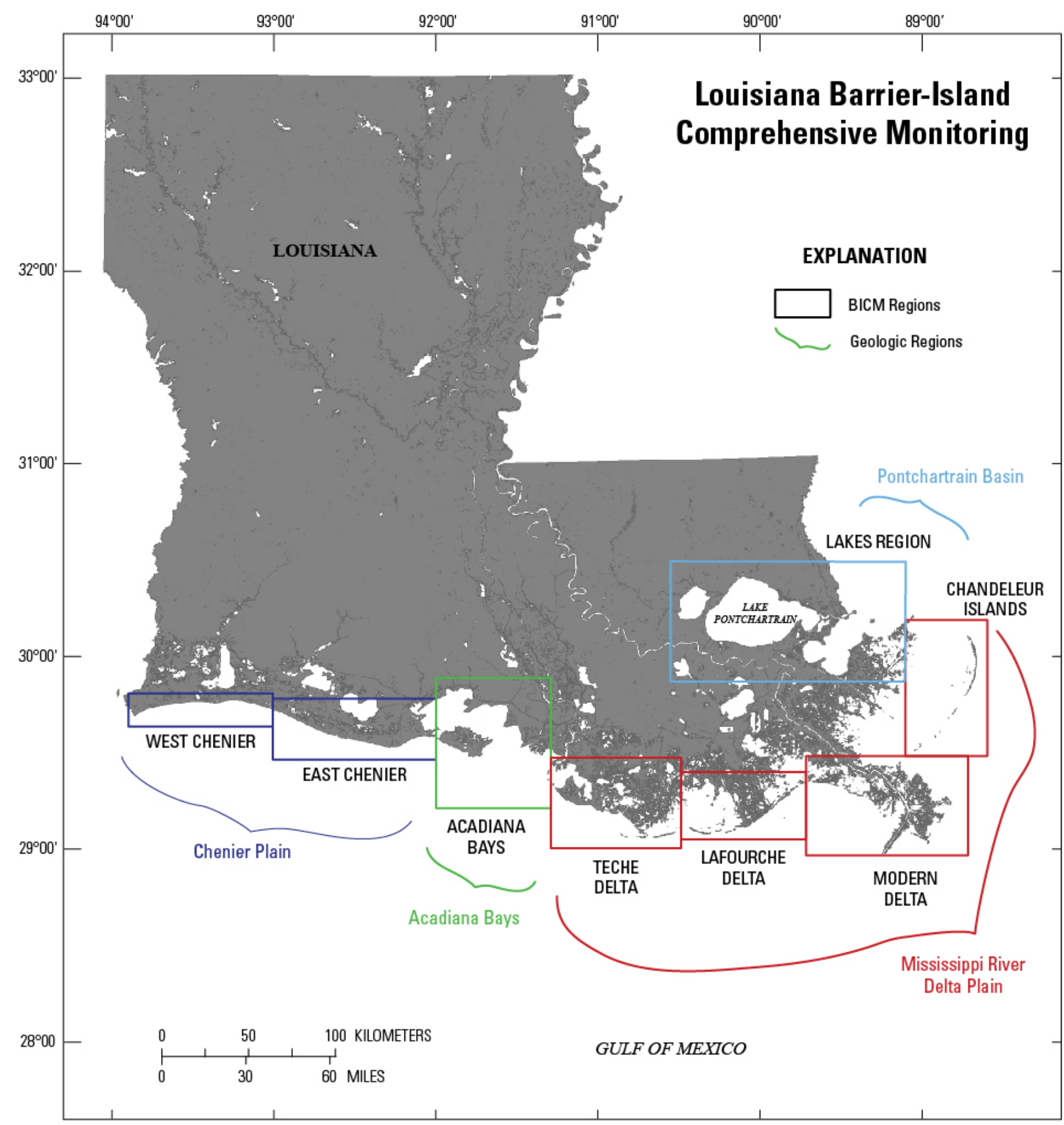

Figure 1. The original four coastal Louisiana shoreline regions based on geologic and physiographic setting (Pontchartrain Basin, Mississippi River Delta Plain, Acadiana Bays, and Chenier Plain) with the eight regions used in BICM analyses (the Lakes Region; Chandeleur Islands; Modern, Lafourche, and Teche Deltas; Acadiana Bays; and the eastern and western Chenier Plain). 
collected to support other tasks (for example, to identify shoreline positions for habitat mapping and land-loss analysis) and overlaps some or all of the geographic areas focused on by other tasks. Data coverage and general products for each of the six tasks and eight BICM regions are provided in figure 2 and table 1.

Although the objectives of BICM were delineated into six tasks, none of them stand alone as single entities. Instead, the tasks are interrelated, and data from one task were commonly incorporated into analyses within other tasks. For example, while the group tasked with collecting and acquiring historical and modern shorelines created their scientific products, the bathymetry group was producing similar products in many of the same areas. Identifying the shoreline location of a barrier island is a result of using the nearshore bathymetry, aerial photography, and lidar topography. These data are also used to map the geomorphology of the area. Islands consist of sandy sediments, and the nearshore sediment texture is a reflection of the source of sediments and the energy of the area. Nearshore surficial sediments were collected as a discrete task within BICM; however, maps depicting sediment properties along with bathymetry and shoreline position provide a basis for interpreting and understanding sediment transport, sediment-source location, sediment depositional sinks, and energy of the environment. Concurrently, another group was tasked with describing habitat classification, habitat change, and land-loss trends. Changes in nearshore bathymetry and barrier-island shape are driven by sediment deposition or erosion caused by nearshore currents and changes in energy, particularly by storms. As a result of these changes, some island habitats can change dramatically while other areas may remain stable over time. Time-series analysis of data collected for all tasks is imperative to monitor these dynamic environments.

The 2006 to $2010 \mathrm{BICM}$ projects primarily focused on the barrier-island environments along the Louisiana coast. The barrier islands extend for more than 150 kilometers (km; 93 miles, mi) from southern Terrebonne Parish east to the western Mississippi River Delta, and north from the eastern side of the delta to the Mississippi Sound. The majority of the data collected for the BICM program focused on these crucial barrier-island systems because these geologic features provide unique habitats and protect fragile estuaries and mainland environments from the full force of tropical storms and hurricanes. To adequately predict island response to storm events, sediment supply, and sea-level change, it is necessary to (1) understand historic shoreline positions and bathymetry; (2) establish baseline topography and bathymetry; and (3) characterize habitats and their distribution.

The geomorphology of Louisiana's barrier islands is a complex arrangement of landscapes produced by fluvial processes and sea-level rise over the past 7,000 years. Currently, mainland and barrier-island configurations are shaped by eustatic sea-level rise, land subsidence, prevailing wave climate, and storm activity. Interactions among these dynamic processes, along with declining historical fluvial deposition, are forcing a redistribution of the antecedent topography to maintain equilibrium with the changing coastal environment. The resulting overall trend is net erosion and shoreline regression; however, variations in landform distribution, textural composition, and land subsidence create areas of localized deposition.

Monitoring barrier-island change requires repetitive surveys of the aerial dimensions of the islands as well as the subaerial nearshore and back-barrier environments. Topographic and bathymetric data provide an easy reference for how the system is changing. Imagery, lidar, and geophysical surveys are the primary tools currently used to gather detailed shoreline position, habitat, and subaerial extent of barrier islands. The results of the BICM program provide data for shoreline and seafloor-change analyses, identify "hotspot" areas that are especially sensitive or require additional research, and link the geologic framework to surficial processes for selected areas.

The Louisiana barrier islands are part of a complex system with many overlapping and interrelated processes. Data for the BICM tasks were collected and compiled with consistent approaches and methodologies. The resulting data are more comparable, consistent, accurate, and complete than previously available barrier-island data that were generated for local projects. BICM databases and survey results provide scientific support for understanding the complex coastal changes that are occurring in coastal Louisiana and provide a baseline dataset for future investigations of the entire Louisiana Coastal Area (LCA) barrier-island system.

\section{Monitoring the Louisiana Coast}

Typically, monitoring and modeling environments and associated physical processes on a regional scale are more complex efforts than on the local scale, primarily because regional studies must consider diverse physical processes that interact at multiple scales. On a regional scale, for example, the benefits of improved habitat in one location may be counteracted by degradation at another location, and the net result could be interpreted as no overall benefit. In addition, regional studies commonly involve monitoring changes in multiple baseline conditions over time or space and typically are very labor intensive. However, regional studies provide a comprehensive assessment of coastal change, whereas local studies typically focus on a single system. When possible, site-specific monitoring and regional-scale information 

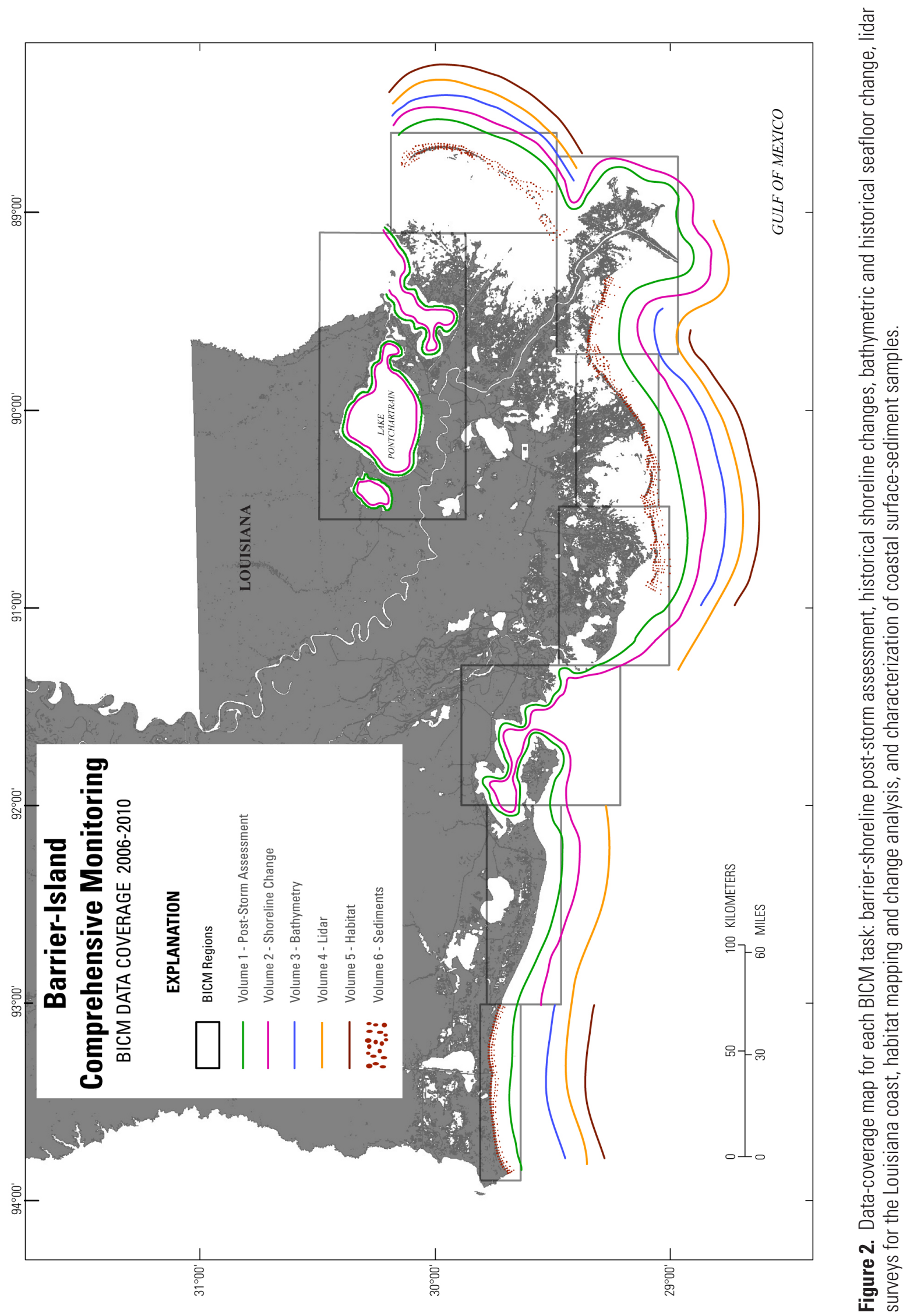


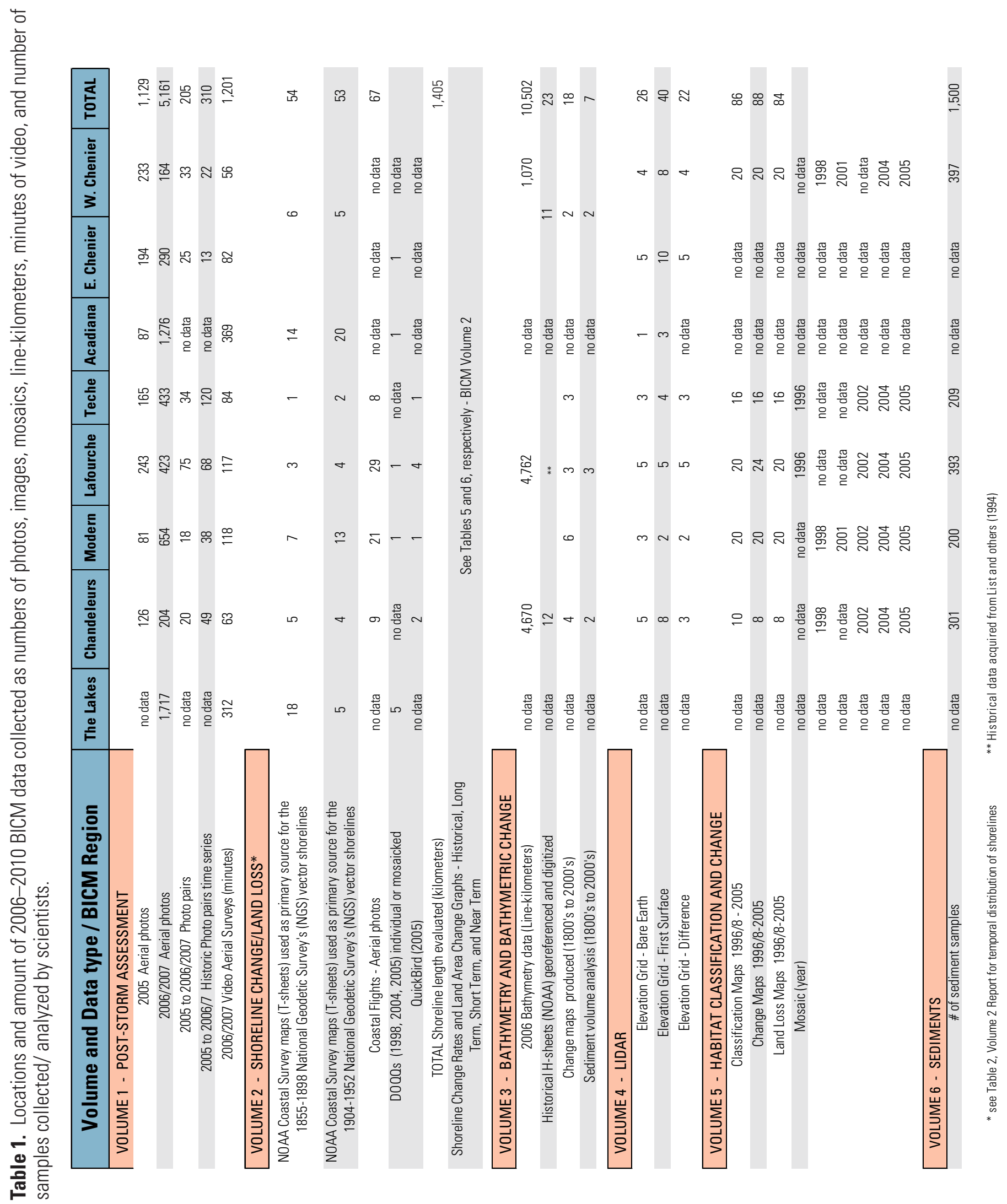


needs should be interrelated. In some cases, regional monitoring efforts may be an extension of ongoing local monitoring projects, but regional-scale monitoring may also involve designs and procedures that are different from site-specific monitoring and may extend beyond the purview of the local project teams. Although regional-scale monitoring efforts may be challenging, the resulting data and analyses enable a more comprehensive understanding of each aspect of the diverse coastal environments and their dependence upon and interactions among each other.

Although the BICM data-collection effort was extensive, the BICM data could also be integrated with data from existing monitoring efforts in coastal Louisiana. For example, the Coastal Wetlands Planning, Protection and Restoration Act (CWPPRA) program has been monitoring restoration and protection projects in coastal Louisiana since 1990 (Steyer and Stewart, 1992; Steyer and others, 1995). The CWPPRA monitoring program incorporates a comprehensive wetlands monitoring and assessment component, the Coastwide Reference Monitoring System (CRMS; Steyer and others, 2003). The establishment of the CRMS network represented a change from local, project-oriented monitoring to regional-scale monitoring and assessment of overall ecosystem health. The proposed BICM program study plan (Troutman and others, 2003) included repeated data-collection efforts along the barrier islands and sandy shorelines every 5 years and was intended to complement CRMS and integrate coastal-shoreline monitoring from numerous restoration efforts. CRMS and BICM provide system-wide performance measures that are evaluated to help determine the cumulative effects of restoration and protection projects in coastal Louisiana, as demonstrated in the Terrebonne Basin Barrier-Shoreline Restoration Project Feasibility-Level Monitoring and Adaptive Management Plan (Louisiana Coastal Area [LCA] Adaptive Management Framework Team, 2010).

\section{Review of Available Data Prior to BICM Implementation}

Several previous studies contributed to our present understanding of the geologic framework and processes in the BICM study area. Williams and others (2012), Flocks, Kulp, and others (2009), Flocks, Twichell, and others (2009), Flocks, Miner, and others (2009), and Kindinger and others (2001) provided a comprehensive review of relevant studies through 2000. Suter and others (1991) conducted a regional nearshore sand-resource inventory from Marsh Island to Sandy Point. The Louisiana Barrier Island Erosion Study, a cooperative study with the USGS and the Louisiana Geological Survey (LGS), investigated the general geologic framework, historical changes, and modern processes affecting the Louisiana barrier islands (Sallenger and Williams, 1989). The final products of the Barrier Island Erosion Study included the publication of a shoreline-change atlas (Williams and others, 1992) and a seafloor-change atlas (List and others, 1994) for the coastline extending from the Isles Dernieres to the modern delta lobe. Williams and others (1992) described the geologic history of the study area and included a detailed series of shoreline maps with accompanying data analysis documenting the evolution of the barrier-island systems since the first shoreline surveys in 1853 . List and others (1994) documented seafloor elevation along the deltaic coast and presented seafloor-erosion and accretion data necessary to understand and describe regional sediment-transport processes along the south-central Louisiana coastline.

With funding from CWPPRA, the State of Louisiana implemented a long-term program constructing multiple local coastal-protection and restoration projects. After a decade of CWPPRA project implementation, Penland and others (2003) assessed five barrier-island restoration projects constructed in Terrebonne Basin along the central Louisiana Gulf Coast. That report provided an extensive review of different restoration methods with respect to environmental benefits and implications for island longevity, as well as logistical challenges encountered during project construction and total construction costs. Penland and others (2003) reported three primary conclusions: (1) the use of dredged material and vegetation to restore barrier-island dunes and back-barrier marsh was the most efficient in terms of effectiveness and cost to manage and mitigate long-term barrier-island erosion; (2) the use of segmented breakwaters and rubble-mound seawalls was less effective and more costly than the use of dredged material and vegetation; and (3) improvements were needed in the final design templates to ensure that the slopes and elevations were correct for back-barrier marsh creation. Many of the findings in Penland and others (2003) have since been incorporated into subsequent CWPPRA and other restoration projects.

Since the early 1980s, the USGS, the LGS, Louisiana State University (LSU), University of New Orleans (UNO), and other State and Federal agencies working in coastal Louisiana have compiled large volumes of data. Some examples include nearshore to offshore geophysical surveys (USGS, LGS, LSU, and UNO), photo mosaics, repeat lidar surveys (USGS and USACE), and the USACE-funded Beneficial Use of Dredged-Material Monitoring Program (2010). Some of these data were incorporated into existing national Geographic Information Systems (GIS) databases such as usSEABED (USGS; http://walrus.wr.usgs.gov/usseabed/) and regional publications such the Environmental Atlas of the Lake Pontchartrain Basin (Penland and others, 2002a). In an effort to facilitate the integration and dissemination of these project-specific data for scientific research, the USGS developed the Louisiana Sedimentary and Environmental Database 
BICM Program Summary Report: Data and Analyses 2006 through 2010

(LASED; http://coastal.er.usgs.gov/lased/), and the Louisiana Department of Natural Resources developed the Strategic Online Natural-Resources Information System (SONRIS).

Historical relative sea-level rise (RSLR) in coastal Louisiana is among the most rapid in the continental United States (Zervas, 2001) and many studies have documented historical land-loss trends and habitat changes in coastal Louisiana (for example, Cahoon and Groat, 1990; Reed, 1995; Barras, 2003; Barras and others, 2008; and Linscombe and Hartley, 2011). But there are very few peer-reviewed habitat-classification studies for coastal Louisiana. The existing studies primarily consist of internal GIS-change analyses conducted for the annual CWPPRA Wetlands Value Assessment process and various state and U.S. Army Corps of Engineers (USACE) restoration-planning documents such as Coast 2050 (LCWCRTF and WCRA, 1998), the LCA (USACE, 2004), and the Louisiana Coastal Master Plan (CPRA, 2007, 2012). The most recent National Wetlands Inventory database for coastal Louisiana is from 2009 (Dahl, 2009) and includes data originally published in Wicker $(1980,1981)$. Various Landsat Thematic Mapper satellite-based land-cover datasets have been used for regional updates, but these generally do not use a common, standardized habitat-classification scheme (for example, Hartley and others, 2000 - GAP, 1993; and Fry and others, 2011 - USGS National Land Cover Database, 2006).

\section{Six BICM Volumes - Data Reports}

The six data-collection tasks under the 2006 to 2010 BICM program were assigned to separate science teams on the basis of area(s) of expertise. In order to meet the objectives outlined in the BICM working plan, the science teams acquired both new and, in some cases, historical data. The data for each BICM task were organized into six data volumes, each of which includes a brief report summarizing the methodology, data, and results. Currently (December 2012), these data volumes can be accessed at:ftp://ftp.dnr.state.la.us/bicm/. Because BICM was largely an extensive data-collection effort (table 1) intended to support long-term coastal monitoring, the data volumes primarily consist of raw data. However, most of the data volumes also include preliminary analyses that establish historical and baseline conditions for future studies, and Volumes 2, 3, and 5 include detailed shoreline, bathymetric, and habitat-change analyses, respectively. In addition, much of the 2006 to 2010 BICM data have been published as part of separate studies, including task-specific peer-reviewed journal articles (for example, Miner, Kulp, Penland, and others, 2009) and a comprehensive analysis of the Breton National Wildlife Refuge (USGS Scientific Investigations Report 2009-5252, Lavoie, 2009). Brief summaries of each of the BICM data volumes follow.

\section{Volume 1: Barrier-Shoreline Post-Storm Assessment}

The Volume 1 aerial video-survey archive includes imagery from 1984 to 2007 (Westphal and others, 2009). The BICM surveys included both still aerial photography and simultaneous video imagery and established a standardized methodology to produce imagery that can be directly compared with imagery from future surveys. The baseline 2005 aerial photography was collected immediately following the landfalls of Hurricanes Katrina and Rita on August 29 and September 24, respectively (Westphal, 2009). As part of the Volume 1 Barrier-Shoreline Post-Storm Assessment, photos from the 2005 and 2006/2007 surveys (Westphal, 2008; Westphal and Penland, 2009) were compared and the resulting photo pairs illustrate recent coastal-landscape change between these time periods (fig. 3). In addition, photographic slide archives for historical surveys conducted between 1984 and 1992 were analyzed for images that overlapped with the recent surveys, and time series encompassing several time periods were created for locations where multiple images were available (Westphal, 2009).

\section{Volume 2: Shoreline Changes and Barrier-Island Land Loss, 1800s to 2005}

Historically, land-loss rates in coastal Louisiana exceeded 100 square kilometers per year $\left(\mathrm{km}^{2} / \mathrm{yr}\right)(37 \mathrm{square}$ miles per year [ $\left.\mathrm{mi}^{2} / \mathrm{yr}\right]$ ) (Dunbar and others, 1992; Barras and others, 2003; National Inventory Report [NIR], 2008). Although land-loss rates have declined since about 1978, recent land-loss rates remain higher than the pre-1950s background rates (Barras and others, 2008; Couvillion and others, 2011; NIR, 2010), resulting in drastic changes to shoreline position, geometry, and configuration. BICM data were used to conduct a comprehensive shoreline-change analysis of the entire coastal shoreline in order to (1) establish a baseline dataset for future restoration efforts; (2) define the character and patterns of historical shoreline change; and (3) quantify the rates of linear shoreline retreat. The effects of the 2005 hurricane season in Louisiana and subsequent development of integrated hurricane-protection and coastalrestoration planning programs made this an appropriate time to collect the baseline data necessary for understanding past 


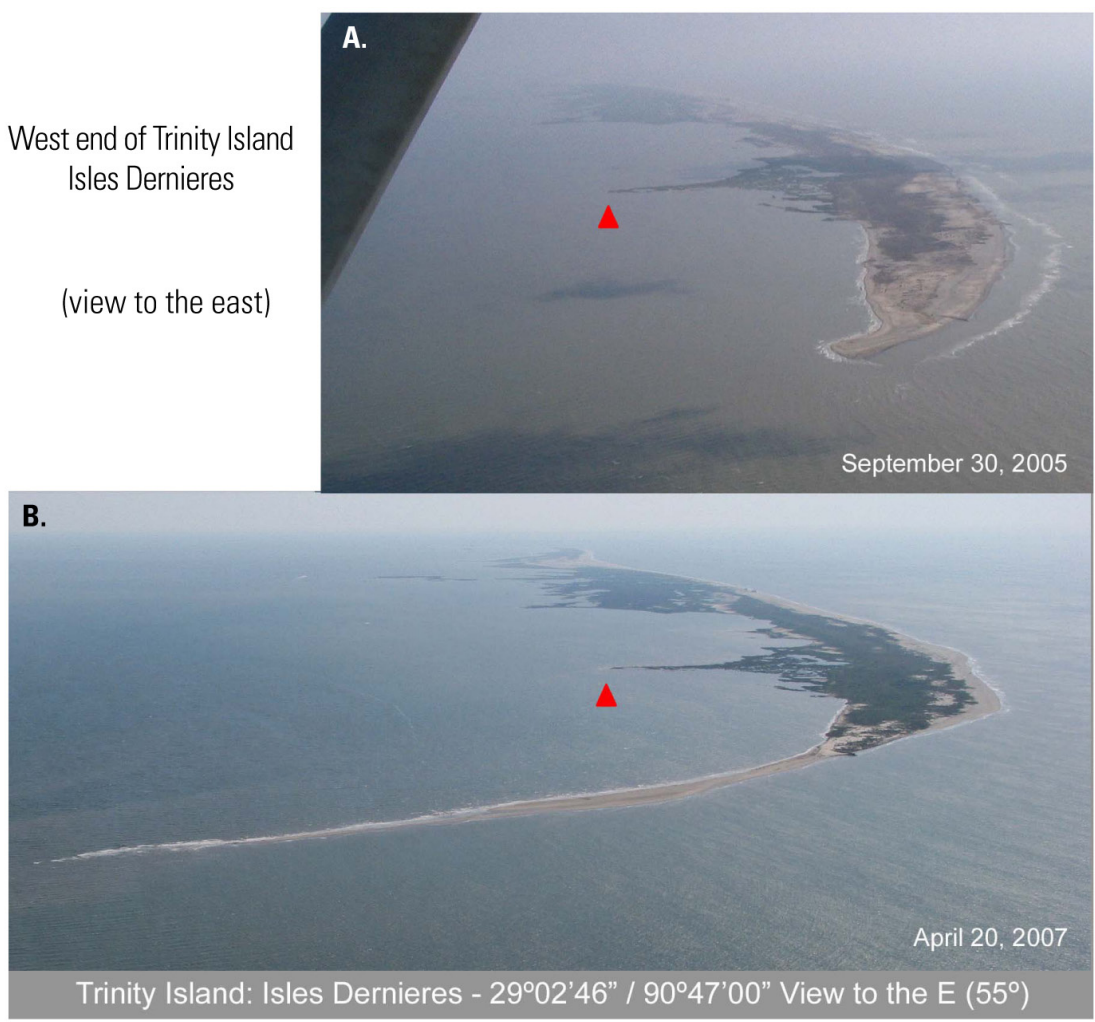

Figure 3. Example of Volume 1 Barrier-Shoreline Post-Storm Assessment aerial time-series photo pair of Trinity Island for 2005 and 2007. Red arrow denotes the same geographic location (BICM Volume 1; Westphal and Penland, 2009).

changes and planning for the future.

In data Volume 2, historical maps, satellite imagery, and aerial photography were integrated to document patterns and rates of shoreline change relative to the high-water line for 80 shoreline reaches over four time periods (figs. 4 and 5): 1855-2005 (historical term), 1920s-2005 (long term), 1996-2005 (short term), and 2004-2005 (near term) (Martinez, O'Brien, and others, 2009a). The average historical and long-term shoreline-change rates were -2.7 and -4.2 meter per year (m/yr) (-8.9 and 13.8 foot per year [ft/yr]), respectively. Between 1996 and 2005, the average short-term shorelinechange rate accelerated to $-8.2 \mathrm{~m} / \mathrm{yr}(-26.9 \mathrm{ft} / \mathrm{yr})$. The average near-term rate of erosion following landfall of Hurricanes Katrina and Rita in 2005 was $-57.8 \mathrm{~m} / \mathrm{yr}(-186.6 \mathrm{ft} / \mathrm{yr})$ (Sallenger and others, 2009). The highest rates of erosion due to the 2005 storm impacts were found along the Isle Dernieres and the Timbalier and Chandeleur Islands, where some shoreline reaches underwent as much as 182 meters (m) (597 feet [ft]) of landward retreat. Shoreline reaches that did not undergo significant shoreline retreat generally were associated with beach nourishment, dune construction, and backbarrier marsh-creation projects.

\section{Volume 3: Bathymetry and Historical Seafloor Change, 1869-2007}

High rates of delta-plain subsidence, ongoing eustatic sea-level rise, and processes such as storms, island segmentation, changes in sediment supply, and human alteration, collectively contribute to shoreline retreat and barrierisland land loss as shoreline sediments are eroded or become inundated by marine waters (Penland and Ramsey, 1990). Although mapping and identifying shoreline changes and the aerial extent of barrier islands is essential to understanding the shoreline and barrier island response to storms, monitoring the subaqueous extent of the islands is also important. A significant component of the BICM program included documenting the historically dynamic morphology within the nearshore, offshore, and back-barrier environments in coastal Louisiana. Data Volume 3 includes (1) compilation of known historic bathymetric datasets from multiple time periods; (2) new bathymetric data collected during the BICM project; and (3) analyses of patterns and rates of seafloor change along selected shorelines. 


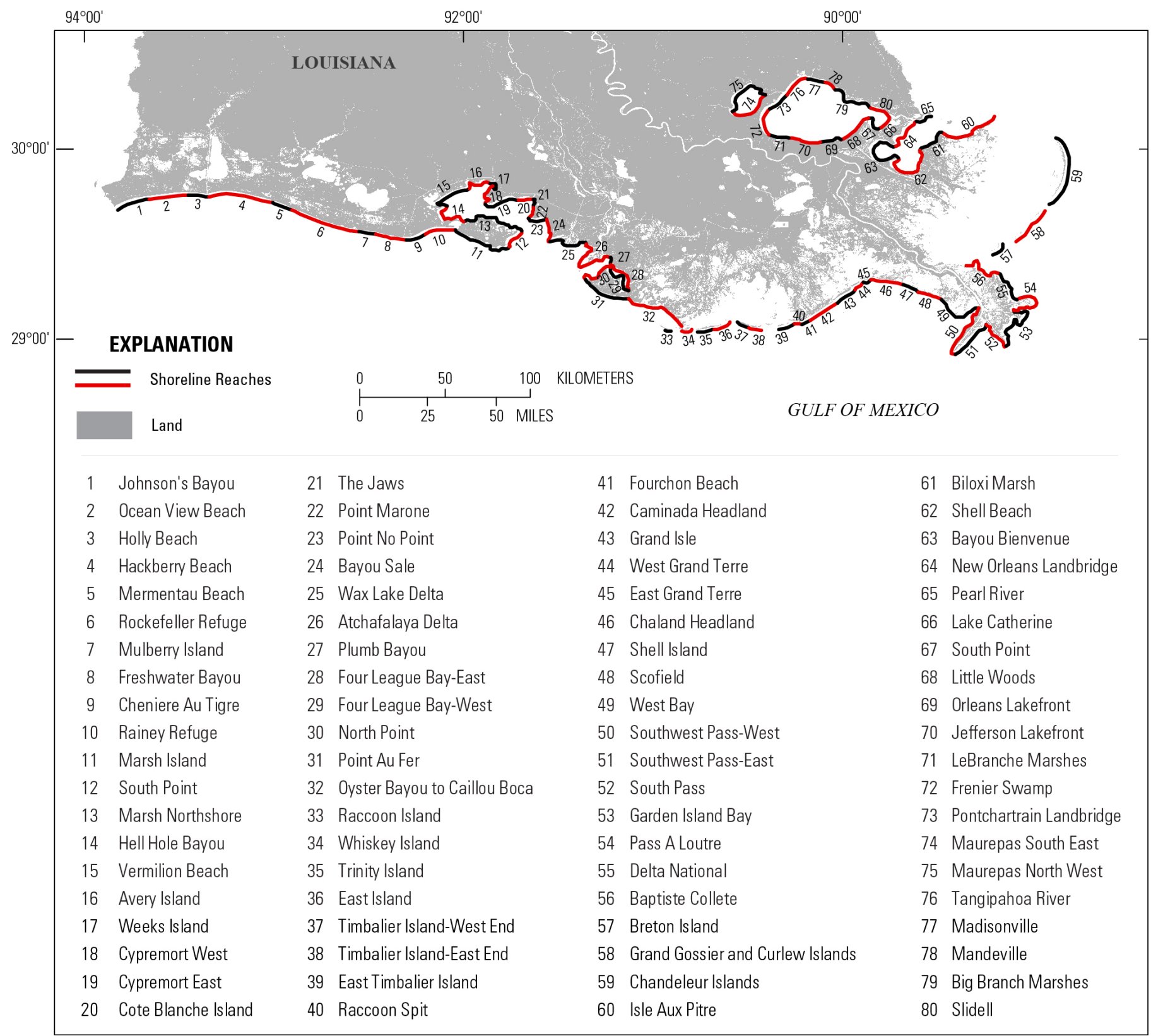

Figure 4. Location map depicting the 80 different reaches of shoreline (numbered on figure) designated during the BICM program to analyze shoreline change for coastal Louisiana. See the Volume 2 data report for maps depicting historical (1855-2005), long term (1920s-2005), short term (1996-2005), and near term (2004-2005) shoreline changes for each of the 80 regions (modified from BICM Volume 2; Martinez, O'Brien, and others, 2009a).

The Chandeleur Islands region provides a good example where historical data were located, georeferenced, digitized, and transformed to a common horizontal and vertical datum for comparison with the recent bathymetric data acquired for BICM (Miner, Kulp, Penland, and others, 2009). From these data, maps were created that depict bathymetric change over approximately 130 years (fig. 6) (Miner, Kulp, Motti, and others, 2009; Miner, Kulp, Penland, and others, 

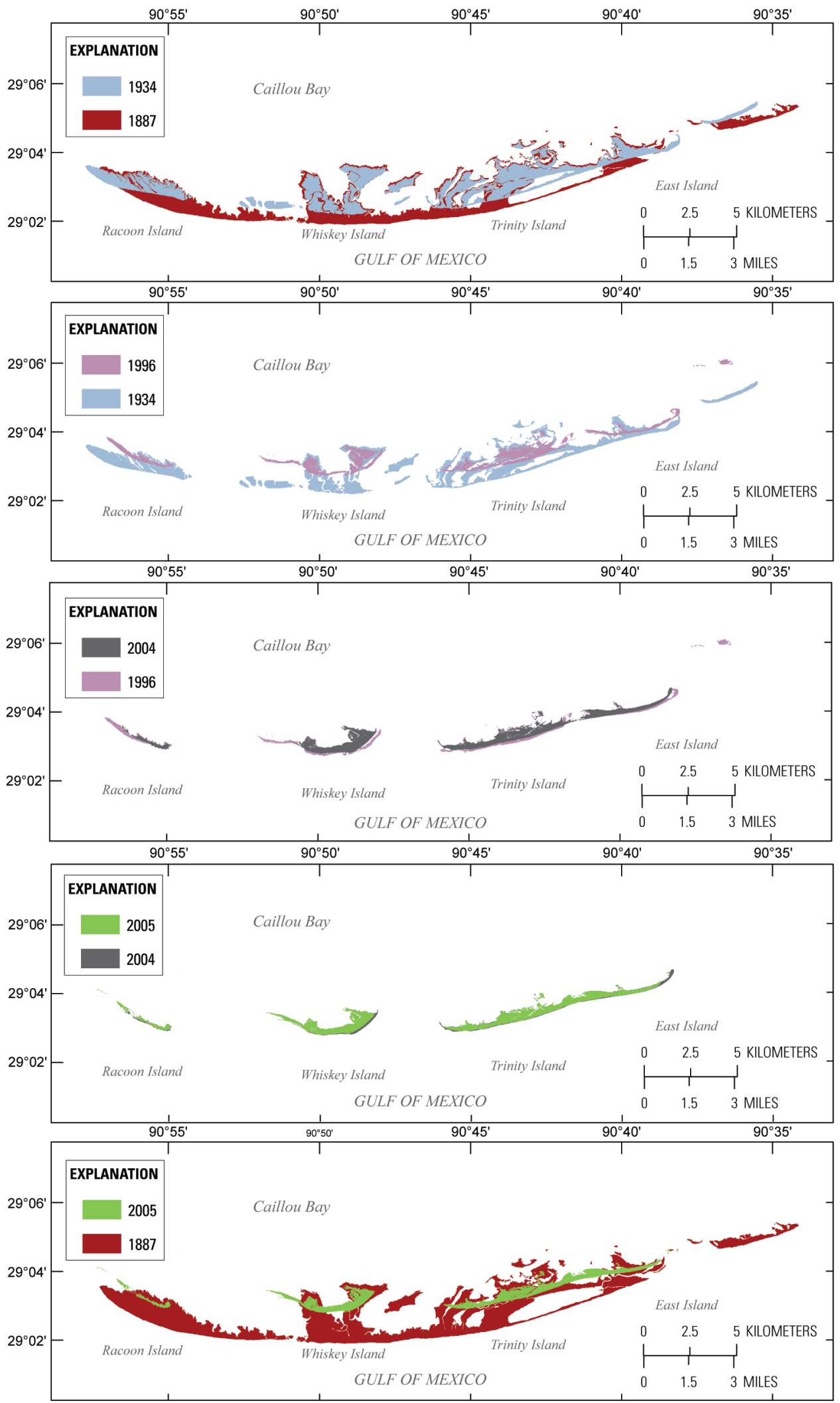

Figure 5. Historical shoreline positions for the Isle Dernieres from 1887 to 2005 with change maps for time periods: 1887-1934, 19341996, 1996-2004, and 2004-2005 (modified from BICM Volume 2; Martinez, O'Brien, and others, 2009a). 
2009; Miner, Kulp, Weathers, Motti, and others, 2009; Miner and others, 2011). Similar datasets were compiled for the Isles Dernieres, Timbalier Islands, and Plaquemines Parish barrier islands and also along the western Chenier Plain beaches. These maps contributed to a comprehensive assessment of the most geologically active portions of the barrier islands. In addition, the most recent surveys conducted by the USGS and UNO will serve as an important baselinebathymetry dataset for future monitoring of the shoreline to measure both storm-induced and long-term coastal change.

\section{Volume 4: Accuracy of EAARL Lidar Ground Elevations Using a Bare-Earth Algorithm in Marsh and Beach Grasses on the Chandeleur Islands, Louisiana}

Topographic surveys of the BICM shorelines were collected using four different airborne lidar systems (Hansen and Howd, 2009; Morgan, 2009). For most of the BICM regions, post-hurricane surveys were flown in September or October 2005 (Chenier Plain, Acadiana Bays, and Chandeleur Islands) using the National Aeronautical and Space Administration (NASA) Experimental Advanced Airborne Lidar (EAARL) system. Post-hurricane data along the Teche, Lafourche, and Modern delta coasts were collected in December 2006 using a Leica ALS50-II lidar system. For each of the regions, the post-hurricane data were compared to data collected in September 2001 (Chandeleur Islands only) or October 2002 using the NASA All Terrain Mapper (ATM) (Hansen and Howd, 2009). Additional surveys were flown over the Chandeleur Islands in October 2005 using the USACE Compact Hydrographic Airborne Rapid Total Survey (CHARTS) lidar system and in March and September 2006, and in June 2007 using EAARL to monitor post-hurricane morphological changes (Doran and others, 2009).

The Chandeleur Islands lost more than 80 percent of their land area during Hurricane Katrina, and many of the islands experienced continued shoreline retreat during the following 2 years (fig. 7). In addition to land-area losses, the decreased dune elevations made the islands increasingly vulnerable to future storm inundation. The USGS, CPRA, and USACE are continuing to monitor changes in shoreline position, land area, and elevation to assess the long-term poststorm response of the Chandeleur Islands.

\section{Volume 5: Chenier Plain, South-Central Louisiana, and Chandeleur Islands Habitat Mapping and Change Analysis 1996 to 2005}

The goal of Volume 5 task was to classify land area by habitat type along five coastal shorelines (the western Chenier Plain; the Teche, Lafourche, and Modern deltas; and the Chandeleur Islands) (figs. 1 and 2) for four discrete time periods (1996 or 1998, 2001 or 2002, 2004, and 2005) and to identify habitat changes that occurred between those time periods (Fearnley, Brien, and others, 2009a). The BICM data sources were color-infrared (CIR), QuickBird satellite and Digital Orthophoto Quarter Quadrangle (DOQQ) imagery for each region and time period. Imagery data were mosaicked, projected to a common datum, and resampled to 2-m (6.6-ft) pixel resolution. Habitat types were classified using the eight categories (water, intertidal, marsh, barrier vegetation, beach, bare land, structure, and riprap) defined by Penland and others (2004). The habitat maps were analyzed to produce habitat- and land-area-change maps for each region (fig. 8) (Fearnley, Brien, and others, 2009b, 2009c). Monthly and annual mean water levels from six USACE tide gages were calculated for the analysis time periods, and differences in mean water level between image-acquisition dates were assessed in the habitat-change interpretations.

Hurricanes Katrina and Rita significantly impacted many coastal habitats within the BICM study areas. In several areas, low-lying habitats were inundated with water and eroded due to flooding and high winds associated with the passage of each storm. This resulted in a decrease in coastal land and habitat areas in 2005. However, some areas also experienced an increase in beach habitat along the coastline as a result of sediment being transported inland with the storm surge. Overall, reductions in the extent of marsh, barrier vegetation, and intertidal habitat occurred due to conversion to beach or open water; these changes can be attributed directly to hurricane impacts (Fearnley, Brien, and others, 2009d; Fearnley, Miner, Kulp, Bohling, Martinez and Penland, 2009; Fearnley, Miner, Kulp, Bohling, and Penland, 2009).

\section{Volume 6: Characterization of Louisiana Coastal Sediment Samples: Back-Barrier through Offshore Samples of the Chenier Plain, South-Central Barrier-Island Systems, and Chandeleur Islands}

Characterization of sediment texture, or grain size, within coastal-zone environments is necessary in order to evaluate relations between sediment-transport patterns, alongshore variability from the shoreline to Depth-of-Closure (DoC), geotechnical properties that influence the development of shoreline nourishment and restoration approaches, and 


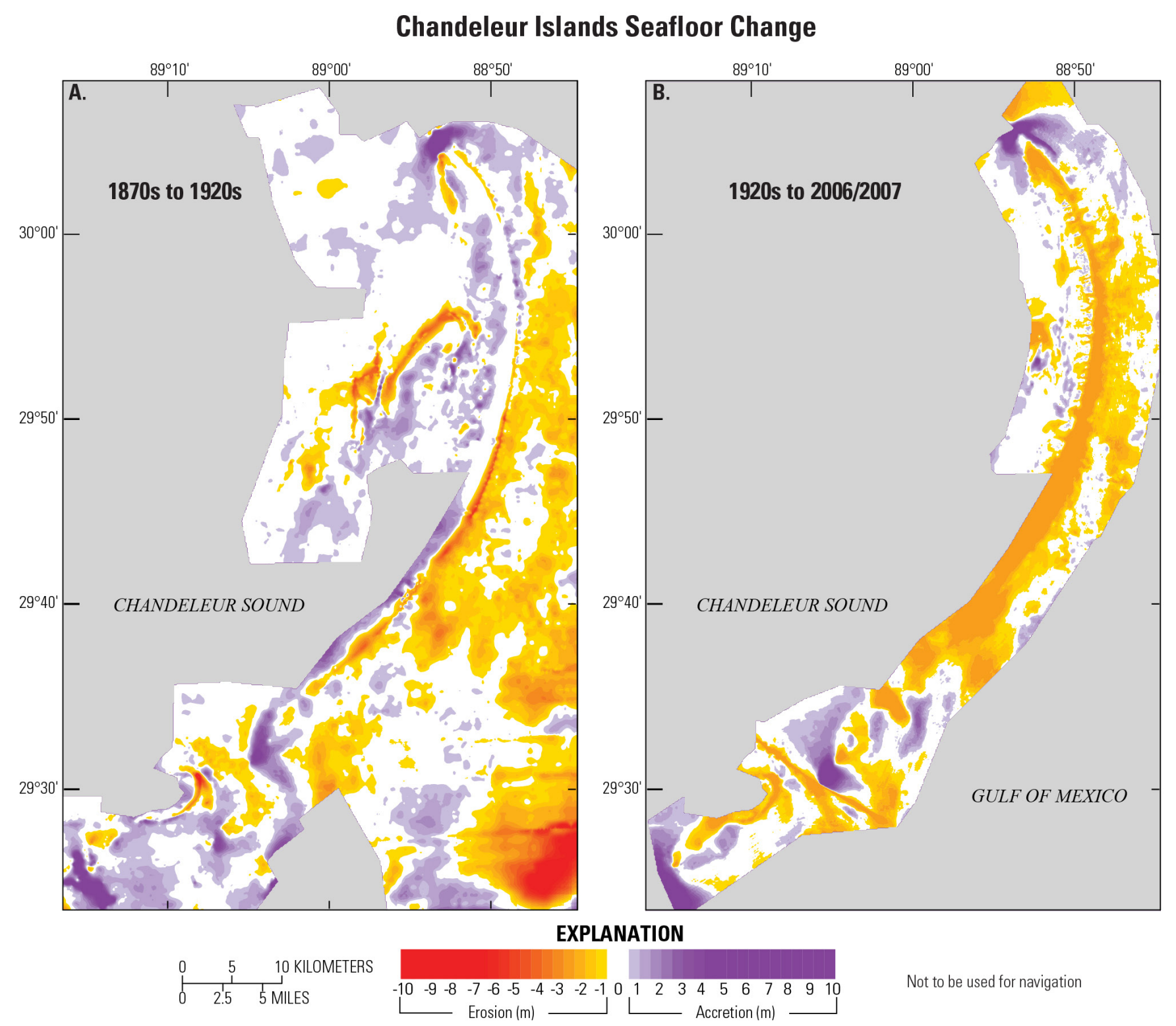

Figure 6. Seafloor-change maps created by digitizing historical bathymetry and collecting data during the BICM program for the northern Chandeleur Islands from (A) the 1870s to the 1920s and from (B) the 1920s to 2006/2007. Warm colors denote erosion, and cool colors show deposition of sediment around the islands (modified from BICM Volume 5; Miner, Kulp, Motti, and others, 2009, Miner and others, and 2011). Abbreviation: $\mathrm{m}$, meter.

to model-anticipated coastal-system response to storm events. Sediment samples were collected during BICM along shore-normal transects across washover platform, back-barrier marsh, dune, beach berm, upper shoreface (mean low water; MLW), middle shoreface, and basal shoreface (seaward to DoC) environments in the western Chenier Plain, Teche, Lafourche, and Modern deltas, and in the Chandeleur Island regions (Kulp and others, 2011a, 2011b). This baseline dataset provides a foundation for restoration monitoring and planning, modeling coastal processes, and developing a better understanding of sediment-dispersal patterns. For example, beach-sediment sampling provided data used to relate fill performance to characteristics of the fill material for beach nourishment and restoration projects. This sampling design also characterized longshore and cross-shore variability in sediment characteristics that will allow assessments of the hydrodynamic zonation of sediments on the islands (fig. 9) and that can be used to help explain habitat distribution and vegetation composition on the islands. 
A.

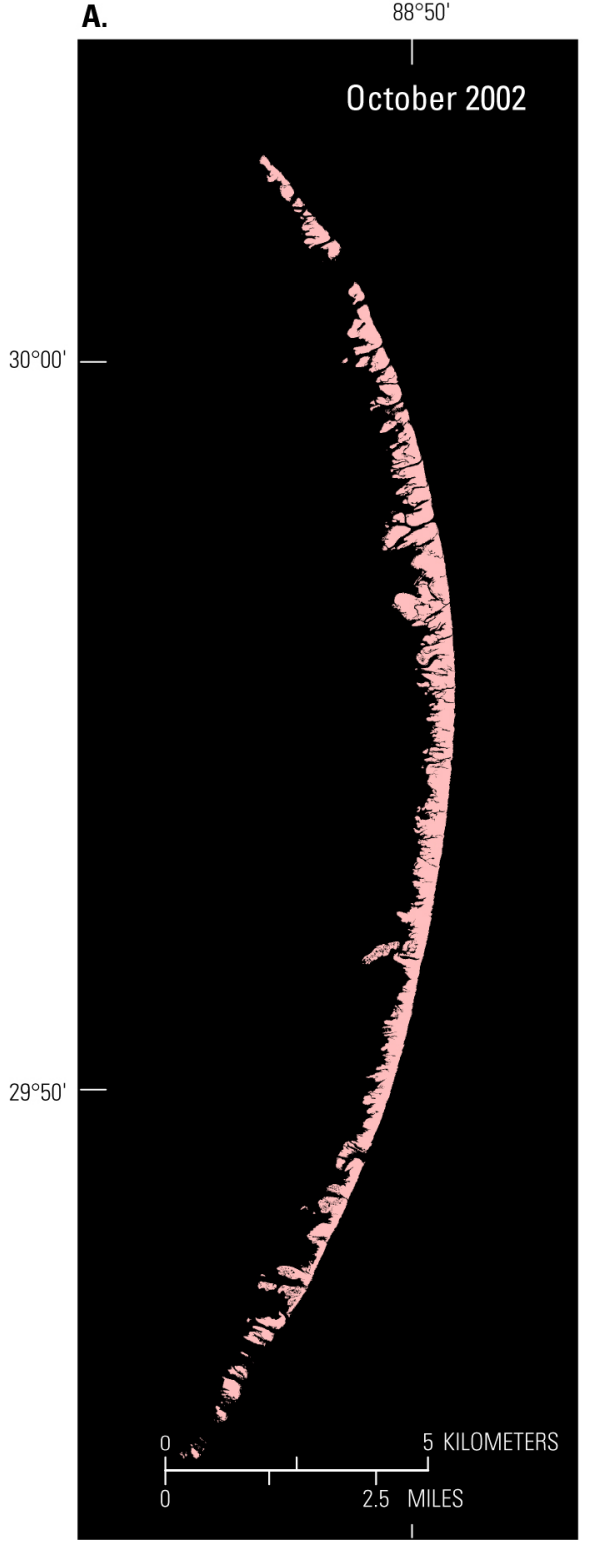

B.

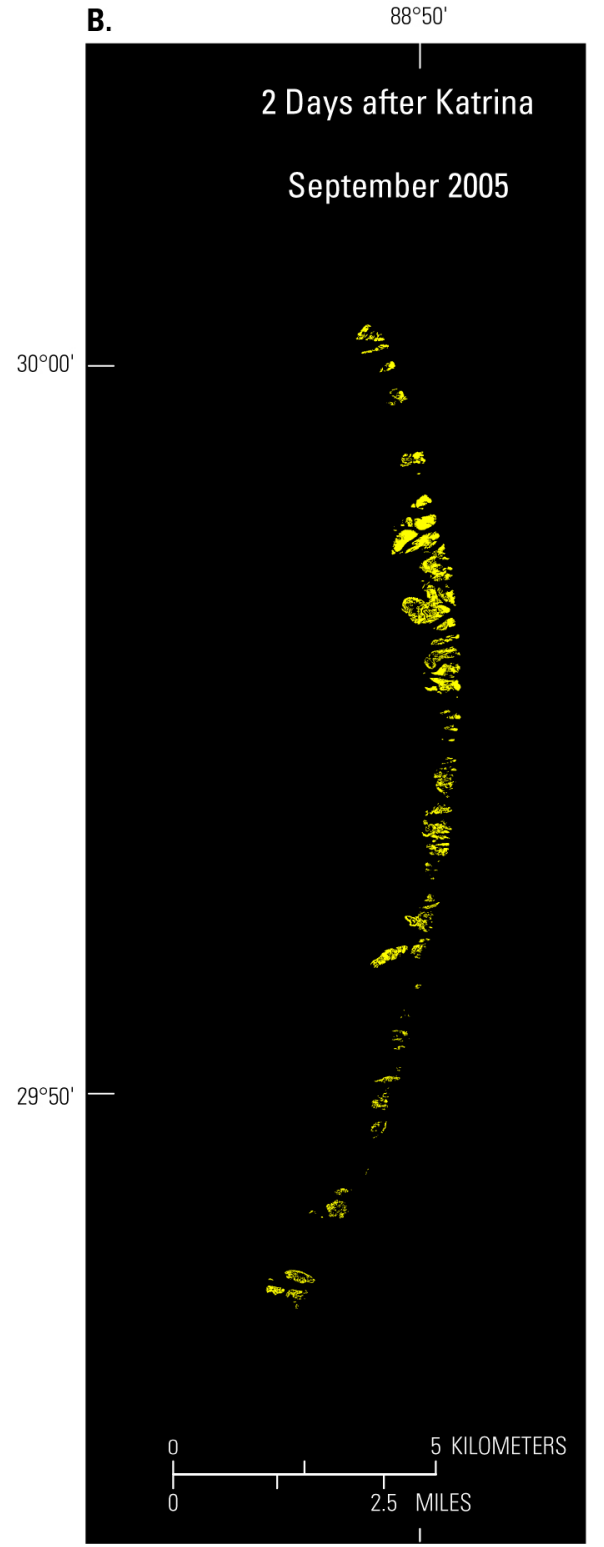

C.

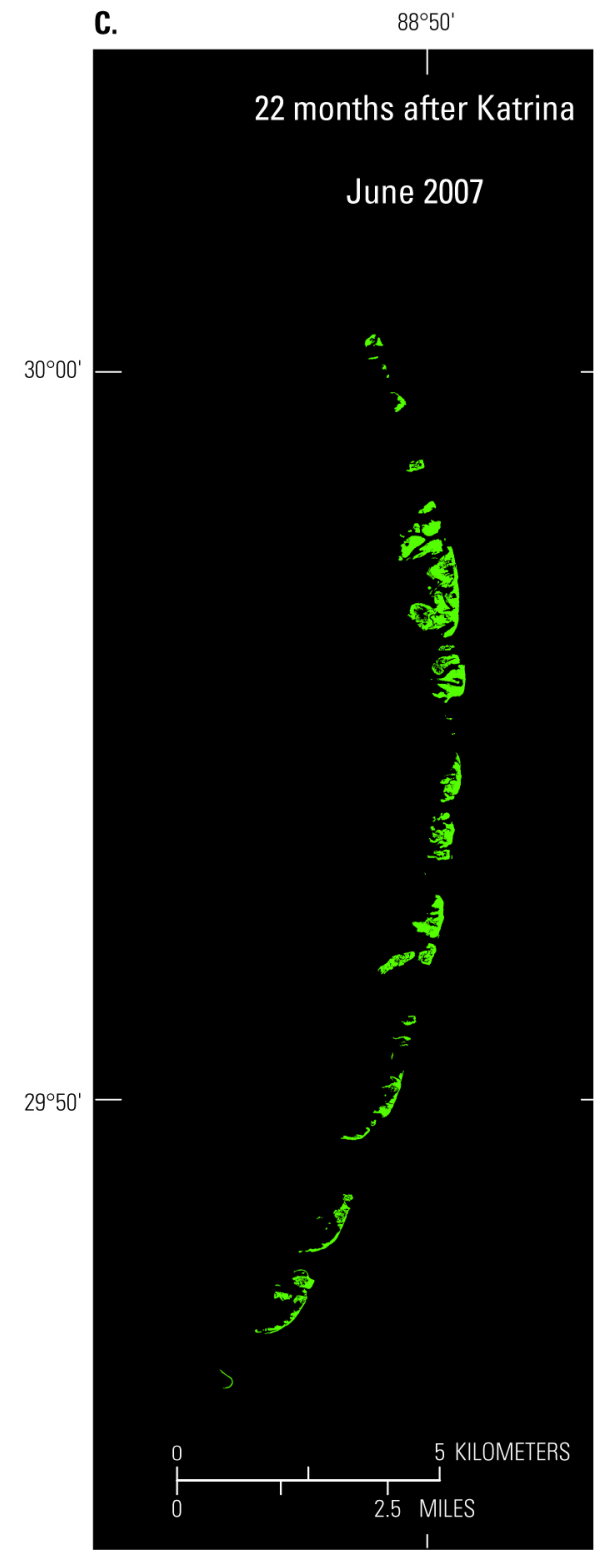

Figure 7. A time-series depiction of lidar data collected for the Chandeleur Islands showing land loss along the island chain over an approximately 5-year period from October 2002 (pink), to September 2005-2 days post-Hurricane Katrina (yellow), and to June 200722 months post-Hurricane Katrina (green) (courtesy, USGS). 


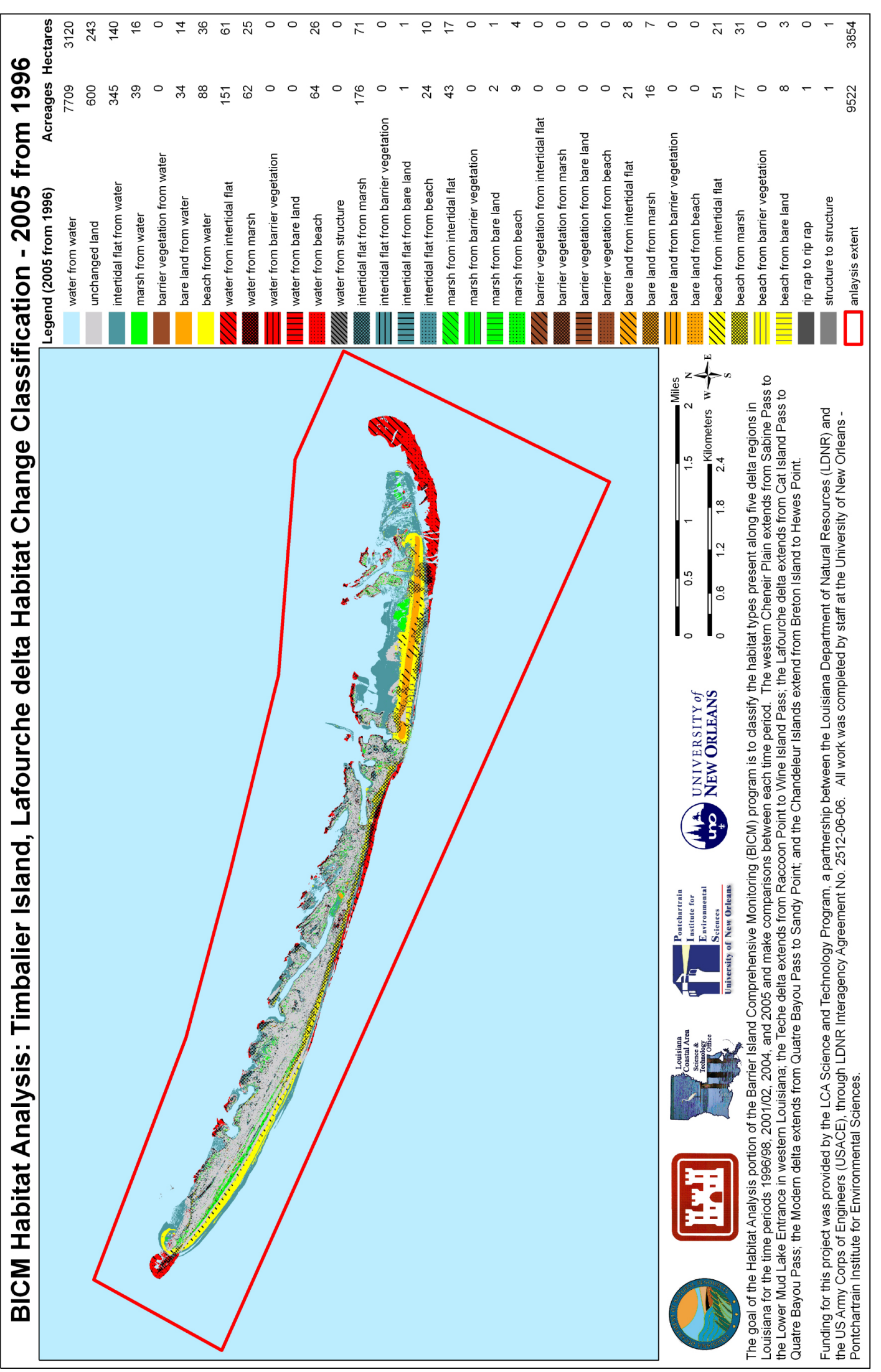

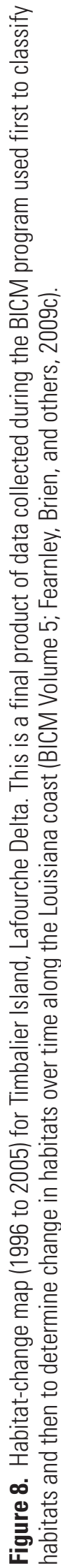


BICM Program Summary Report: Data and Analyses 2006 through 2010

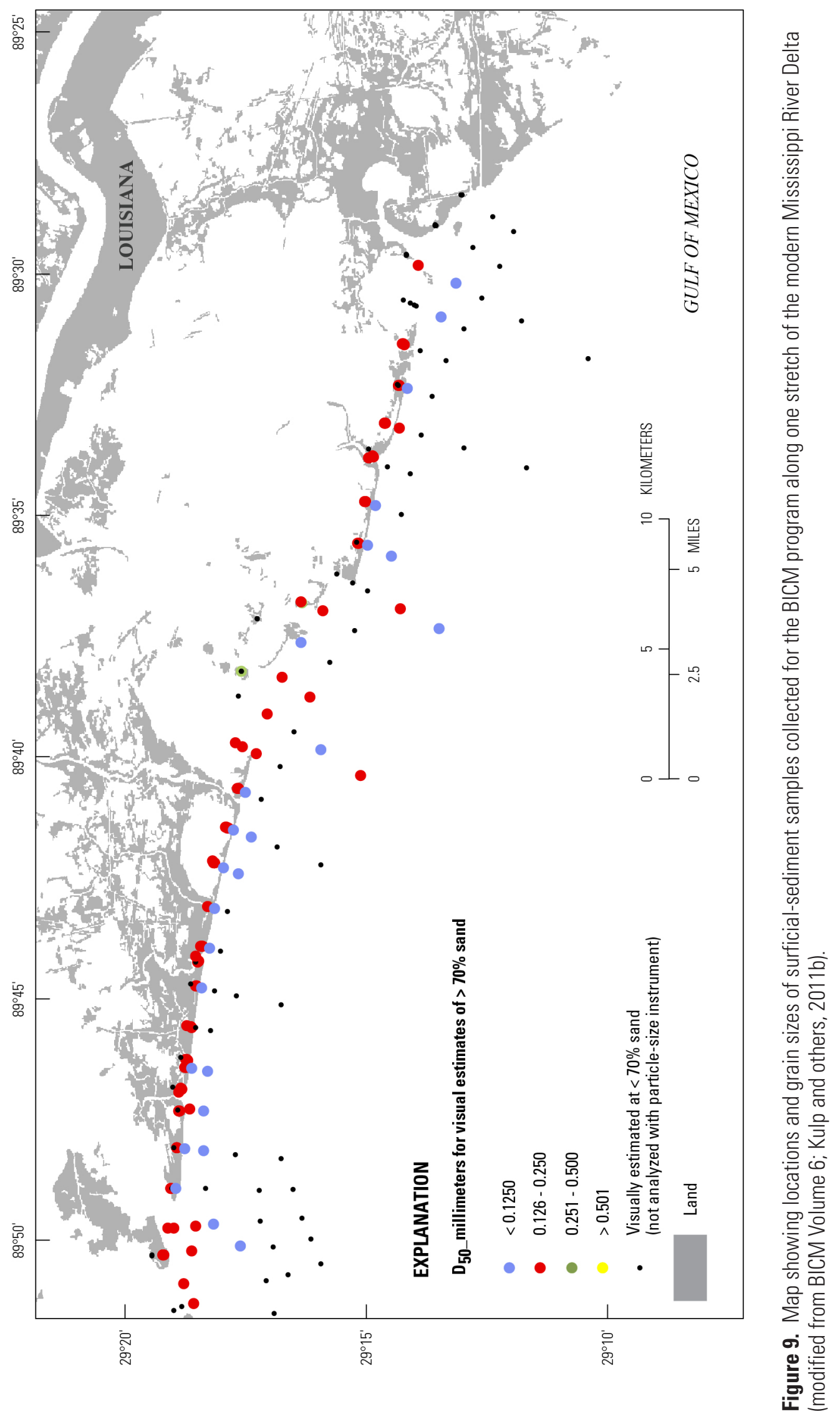




\section{Regional Discussions}

Multiple large datasets were acquired throughout the extent of the Louisiana coast during the 2006 to 2010 BICM program (table 1). The coast encompasses several geologic and physiographic settings and multiple unique habitats. In order to provide the necessary scientific context and background to understand and interpret the BICM data, the eight BICM regions were grouped into four areas: (1) the Pontchartrain Basin, (2) the Mississippi River Delta Plain, (3) the Acadiana Bays, and (4) the Chenier Plain (figs. 1 and 2). Each of the following regional discussions includes a brief description of the geologic setting and BICM results, with a mention of major topographic, bathymetric, habitat, and storm-impact changes that occurred in that region.

The subsurface geologic framework and surface topography of the Louisiana coast reflect a complex history of regional plate-tectonic events and fluvial, deltaic, and marine sedimentary processes affected by numerous largemagnitude sea-level variations (Salvador, 1991; Flocks, Twichell, and others, 2009). Despite the complexity, a long history of in-depth investigations yielded a substantial understanding of the regional geologic evolution and framework and the processes that shape the coast. Kulp and others (2005) provided an excellent review of the geologic history and framework of the north-central Gulf of Mexico basin with a specific emphasis on Holocene processes and geomorphologic features of the Louisiana coast.

The 300-km- (186-mi) wide deltaic plain is the product of continuous sediment accumulation deposited by the Mississippi River and its distributaries within the entrenched Pleistocene alluvial valley during the last 8,000 to 7,000 years as sea level rose to within $-10 \mathrm{~m}(-30 \mathrm{ft})$ of its present position. The delta plain is composed of six major delta complexes (fig. 10) consisting of at least 18 smaller deltaic lobes. Several classic studies (for example, Fisk, 1955, 1961; Kolb and Van Lopik, 1958; Coleman and Gagliano, 1964; Frazier, 1967) focused on the regressive phase of Mississippi Delta sedimentation, during which overlapping, stacked sequences of unconsolidated sands and muddy deltaic sediments were deposited adjacent to the active distributary channel(s). Delta-lobe switching occurred about every 1,000 years as fluvial gradients along the active distributary decreased and the available accommodation space filled (Coleman, 1981; Roberts, 1997). There are relatively few discussions of the corresponding transgressive component of the Mississippi Delta, in particular those of Boyd and Penland (1981) and Boyd and others (1989). Following abandonment of individual delta lobes or delta complexes, dewatering, compaction, and subsidence of the unconsolidated deltaic sediments contributed to regional sea-level rise and submergence of the former deltaic headland. The coarser-grained deltaic sediments were reworked by marine processes to form transgressive coastlines, barrier-island systems, and, ultimately,

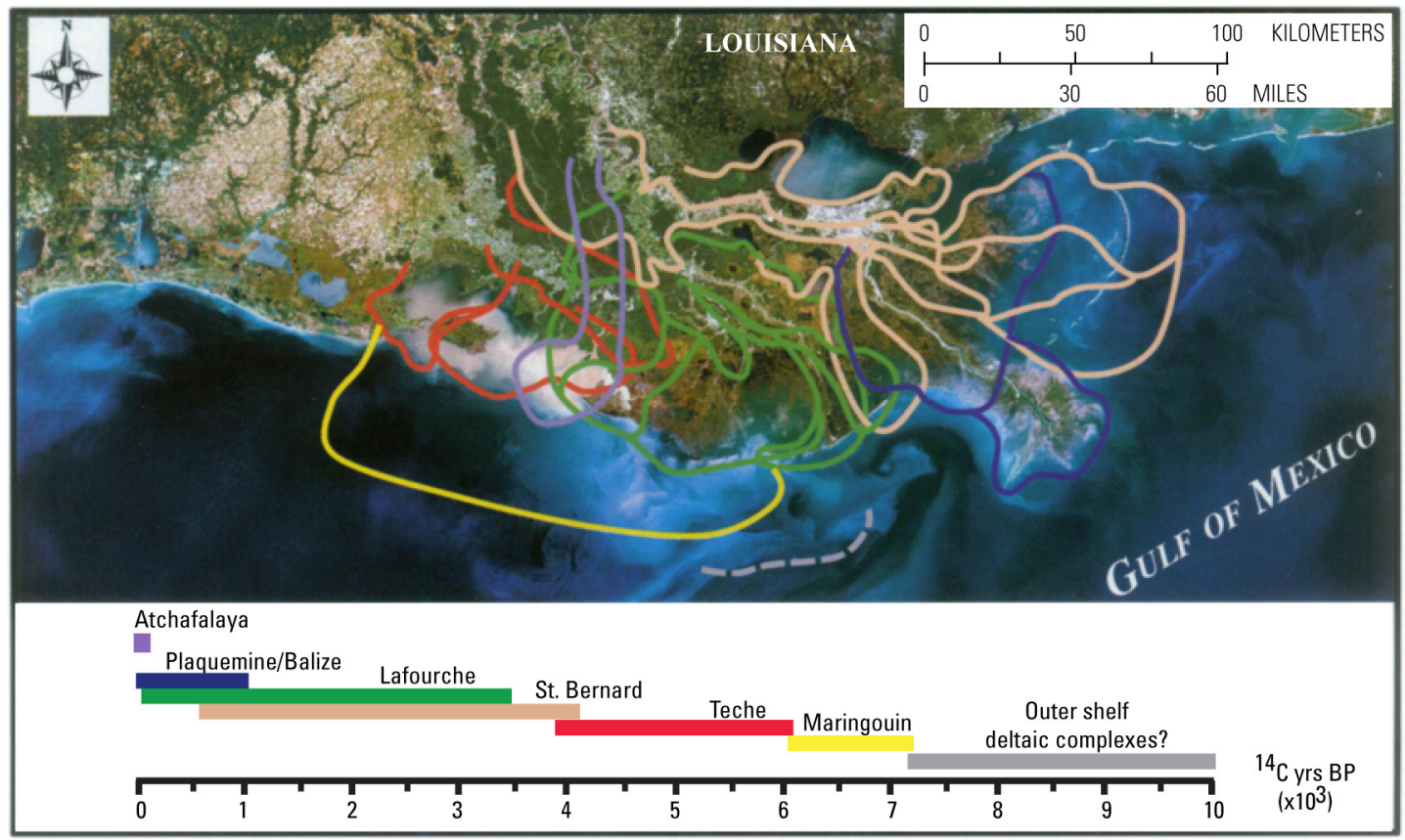

Figure 10. Distribution and chronology of Holocene Mississippi River delta complexes (modified from Kulp and others, 2005). 
submerged sand shoals on the continental shelf, and the finer-grained sediments were concentrated in back-barrier marsh and estuarine environments (van Andel, 1960; van Andel and Poole, 1960; Frazier, 1967; Coleman, 1988; Boyd and Penland, 1988; and Boyd and others, 1989).

In addition to periodic shifts in the course of the Mississippi River, sea-level rise has influenced the development of the delta plain. From a maximum lowstand at approximate depths of -110 to $-150 \mathrm{~m} \mathrm{(}-360$ to $-490 \mathrm{ft})$ at the end of the Pleistocene Epoch (Curray, 1960; Frazier, 1974; Suter and others, 1987), relative sea level rose rapidly ( $>0.02 \mathrm{~m} / \mathrm{yr}$; $>0.065 \mathrm{ft} / \mathrm{yr}$ ) during the early Holocene to within $-10 \mathrm{~m}$ ( $-30 \mathrm{ft}$ ) of present levels by 7,500 years ago (Coleman, 1988; Penland and Boyd, 1981; Penland and others, 1988). Since the middle Holocene, sea level has continued to rise gradually, primarily due to compaction and subsidence of thick $(>100 \mathrm{~m},>300 \mathrm{ft})$ Holocene deltaic sediments.

The geologic history of the Chenier Plain is closely linked to depositional processes in the delta plain. Beginning about 3,000 years ago, alongshore processes began depositing fine-grained deltaic sediments in prograding mudflats along the Chenier Plain coastline. When the Mississippi River deltaic depocenters shifted to the east, sediment supply to the Chenier Plain decreased, and the mud-rich sediments were reworked by coastal processes, which concentrated the coarsergrained sediments into shore-parallel, transgressive, sandy, beach ridges ("cheniers"). The extant topography, consisting of broad mudflats capped by wetland vegetation separated by intervening narrow cheniers, is a result of repeated cycles of deposition and sediment reworking.

\section{Lakes Region - Lake Pontchartrain Basin}

The estuarine ecosystem that includes Lake Pontchartrain is one of the largest in the United States. The lake originated as an embayment open to the Gulf of Mexico and covers an area of 1,632 $\mathrm{km}^{2}\left(630 \mathrm{mi}^{2}\right)$ that rarely exceeds $6 \mathrm{~m}$ (20 ft) of water depth (figs. 1 and 2). The tidal estuaries of Lake Pontchartrain, Lake Maurepas, and Lake Borgne together occupy more than $15,000 \mathrm{~km}^{2}\left(5,792 \mathrm{mi}^{2}\right)$ and represent the drainage terminus of the Pontchartrain Basin watershed (fig. 11). The watershed encompasses approximately $44,000 \mathrm{~km}^{2}\left(16,989 \mathrm{mi}^{2}\right)$ of rolling hills, woodlands, estuaries, and wetlands that support agricultural, coastal, urban, and industrial communities (fig. 1).

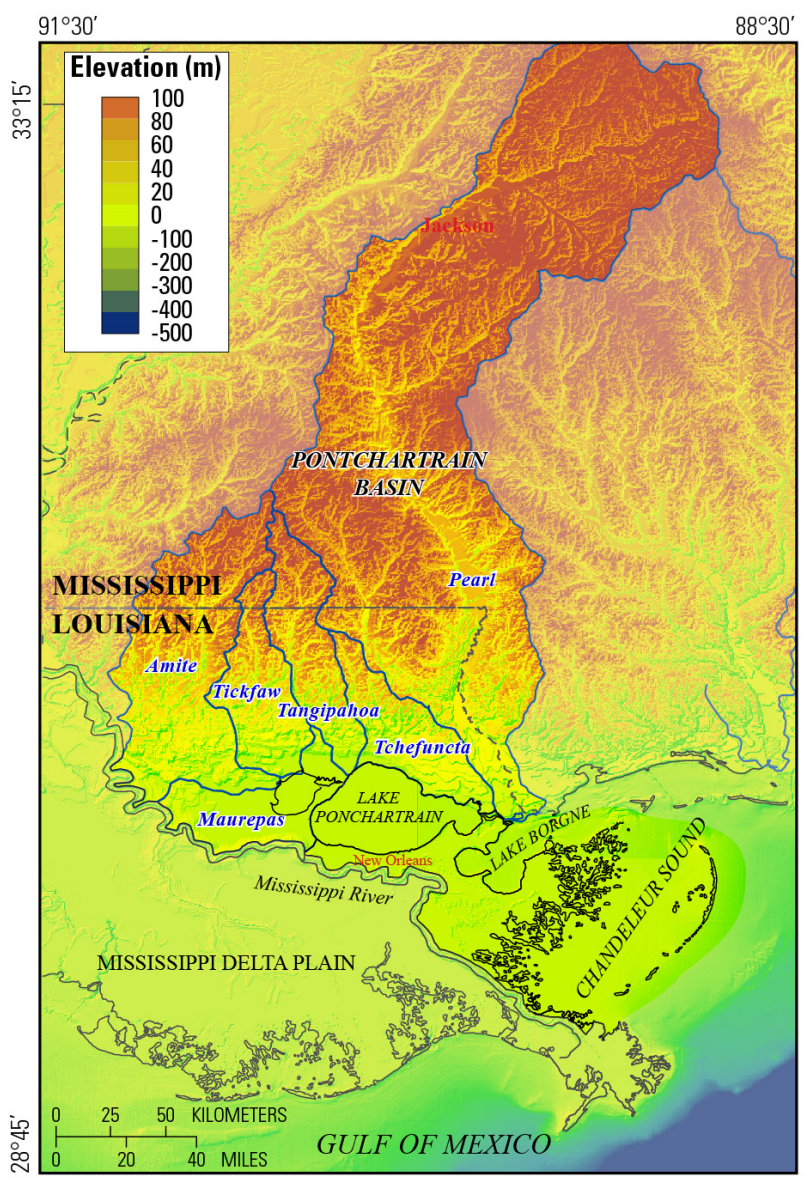

Figure 11. Map of the Pontchartrain Basin showing the river basins that drain into Lakes Pontchartrain, Maurepas, and Borgne (modified from Flocks and others 2009a). 
The areas around Lake Pontchartrain support a population of 2 million, or nearly one-half of the inhabitants in Louisiana (http://coastal.louisiana.gov/index.cfm? $m d=$ pagebuilder\&tmp=home\&pid=112 - accessed Dec. 2012). Over the past two centuries, human activities have significantly controlled and impacted the geography and environmental quality of the lake. Much of the southern shoreline is armored to prevent shoreline erosion, and manmade transportation corridors reduce hydrologic connectivity through the Rigolets and Pass Manchac tidal channels and control tidal interchange with the Gulf of Mexico. Agricultural and stormwater runoff, deforestation, and shell dredging have degraded water quality, reduced habitat, and increased erosion in the surrounding wetlands. By the end of the twentieth century, much of the commercial and recreational value of the lake had been damaged (Penland, Beall, and Kindinger, 2002). Following the Pontchartrain Basin Restoration Act of 2000, a variety of monitoring, research, and restoration activities has led to an enhanced understanding of the ecosystem, and several ecosystem-restoration initiatives and management plans have been implemented (Penland, Beall, Bristch, and Williams, 2002, Penland, Beall, and Kindinger, 2002; Penland, Beall, and Maygarden, 2002; Reed, 2009).

The evolution of the Pontchartrain Basin began 60 million years ago with the formation of the Gulf of Mexico. However, most of the present morphologic features, including Lake Pontchartrain, developed during the last 1,000 years (kyr) (Flocks, Kulp, and others, 2009). A prominent feature of the Pontchartrain Basin is a series of terraces north of the lake that were formed over numerous glacial cycles from the Pliocene through the Pleistocene. These alluvial deposits dip to the south and are overlain south of the lake by the Holocene deposits of the Mississippi River Delta Plain.

During the late Holocene, as rising sea level approached present levels, longshore transport developed a barrierisland system that extends from Mobile Bay to the Pontchartrain embayment. By 4,000 years ago, while the locus of delta building was in west-central Louisiana, the barrier-island systems migrated westward into the area that is now Orleans Parish. This barrier-island system, known as the Pine Island trend, initiated closure of the incipient Lake Pontchartrain

18,000 years ago

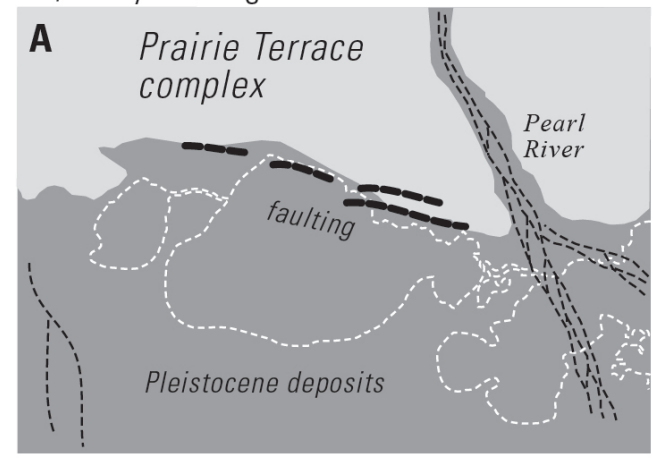

1,000 years ago

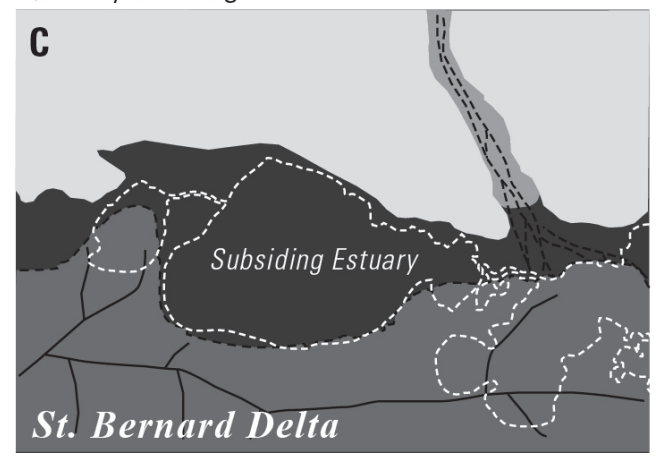

4,000 years ago

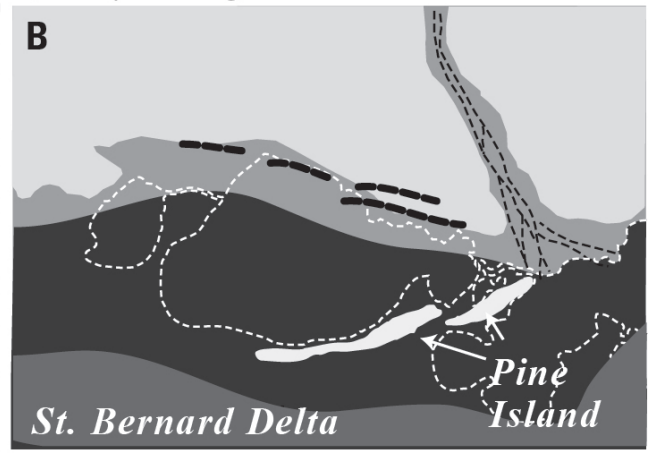

Present

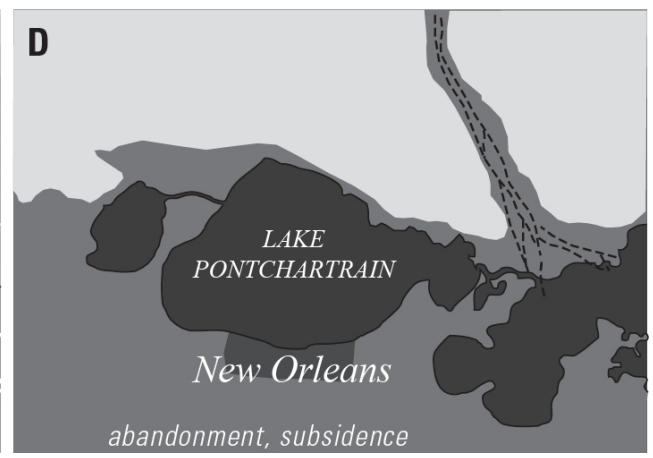

Figure 12. Holocene evolutionary model of Lake Pontchartrain: (A) Sea-level lowstand at the end of the Late Wisconsinan exposed the Prairie Terrace Formation that was incised by rivers extending to the shelf edge. (B) During the Holocene transgression, longshoretransport processes led to the development of the Pine Island barrier trend. This mid-Holocene trend extends from the Pearl River Delta toward the west to the modern subsurface of New Orleans. (C) The Pine Island complex is thought to have ceased development as the St. Bernard delta complex prograded across the Pontchartrain Basin from the west, effectively closing off the estuary from the open Gulf of Mexico and (D) forming the present southern shoreline of Lake Pontchartrain (modified from Flocks, Kulp, and others, 2009). 
BICM Program Summary Report: Data and Analyses 2006 through 2010

from the Gulf of Mexico. Eventually, the Mississippi River avulsed eastward, forming the St. Bernard delta complex across modern Plaquemines Parish, burying the Pine Island trend, and creating the modern morphology of wetlands, lakes, and the Chandeleur Islands (fig. 12). This region is referred to as the Lakes Region because of the system of lakes that developed during this time.

The elevation difference between Lake Pontchartrain and neighboring metropolitan New Orleans creates an extremely vulnerable environment for flooding by tropical storms. New Orleans' elevations average $1.8 \mathrm{~m}(5.9 \mathrm{ft})$ below lake level, necessitating protection by a system of levees, and stormwater from the city is pumped into the lake. In addition, high rates of sea-level rise due to regional subsidence contribute to the ongoing loss of wetlands and barrierislands, which abate storm surge and wave activity during storm events. The extreme vulnerability of New Orleans to storm impact was demonstrated in the aftermath of Hurricane Katrina in 2005. On August 29, the eye wall of Katrina passed along the eastern edge of the lake. The city of New Orleans experienced wind speeds in excess of 160 kilometers per hour (kph) (100 miles per hour [mph]) and a surge of 6-9 m (20-30 ft) (Heitmuller and Perez, 2007). The system of protection levees failed at several locations, and $277 \times 10^{6}$ cubic meters $\left[\mathrm{m}^{3}\right]\left(9,782 \times 10^{6}\right.$ cubic feet $\left.\left[\mathrm{ft}^{3}\right]\right)$ of water from Lake Pontchartrain, Lake Borgne, and the Chandeleur Sound flooded Orleans and St. Bernard Parishes. Four days after the storm, analyses of lidar topography indicated that $150 \mathrm{~km}^{2}\left(60 \mathrm{mi}^{2}\right)$ of the New Orleans area was flooded by $1 \mathrm{~m}$ (3.28 ft) of water and that water was $3 \mathrm{~m}(9.8 \mathrm{ft})$ deep over $25 \mathrm{~km}^{2}\left(9.7 \mathrm{mi}^{2}\right)(\mathrm{Gesch}, 2007)$. The water remained for 2 weeks and mixed with wastewater, petrochemicals, and other waste associated with the industrial corridor. The bulk of this contaminated water was then pumped back into Lake Pontchartrain. Heitmuller and Perez (2007) estimate that 100 to 200 billion liters (22-44 billion gallons) of water were discharged into the lake; their study concludes that most of the waterborne contaminants and microorganisms were flushed out of the lake through the Rigolets and Chef Menteur tidal passes. Elsewhere in the Pontchartrain Basin, saltwater intrusion from the floodwaters damaged floodplain forests and eroded shorelines (Barras, 2007; Faulkner and others, 2007). In wetland areas surrounding the lake, introduction of organic material from the storm surge initiated increased plant growth and elevation, although this increase had dissipated 2 years after the storm (Reed and others, 2009).

Future evolution of the Pontchartrain Basin is dependent on continued geologic change. This change is most dramatically expressed in wetland loss and shoreline erosion as sediment compaction and fault-related subsidence, coupled with RSLR, impact the southern portion of the basin. Increasing open-water areas expose major industrial and metropolitan centers to storm impact. Continued investigation and monitoring of the processes that drive this change are necessary to properly manage the coastal zone and protect the ecosystem and human population.

The BICM program has limited data from the Lakes Region. Data Volume 1 contains video aerial surveys from 2006 and 2007, and an oblique digital-photo survey in 2007. Data Volume 2 has shoreline-change analysis from 1880 to 2005.

History of Topographic and Bathymetric Changes

Rates of shoreline retreat in the Lakes region accelerated along most shoreline reaches since 1855, averaging $-1.5,-2.4$, and $-3.0 \mathrm{~m} / \mathrm{yr}(-5.0,-7.9$, and $-10.0 \mathrm{ft} / \mathrm{yr})$ for the historical (1855-2005), long-term (1904-2005), and short-term (1996-2005) periods, respectively (fig. 13). Following landfall of Hurricane Katrina, near-term (2004-2005) shoreline-change rates in this region increased significantly, averaging $-11.9 \mathrm{~m} / \mathrm{yr}(-39.0 \mathrm{ft} / \mathrm{yr})$ (Martinez, O'Brien, and others, 2009a). No bathymetric or lidar data were collected in the Lakes Region during the BICM project.

\section{Habitat Change}

The BICM project did not collect habitat classification or change data in the Lakes Region. This is an important data gap in the BICM program.

\section{Impacts of Storms}

The elevation difference between Lake Pontchartrain and neighboring metropolitan New Orleans creates an extremely vulnerable environment for impact by tropical storms. Post-Katrina BICM imagery was collected in the Lakes region in 2006 (aerial photography) and 2007 (video aerial surveys) (fig. 14; Westphal and others, 2009). 


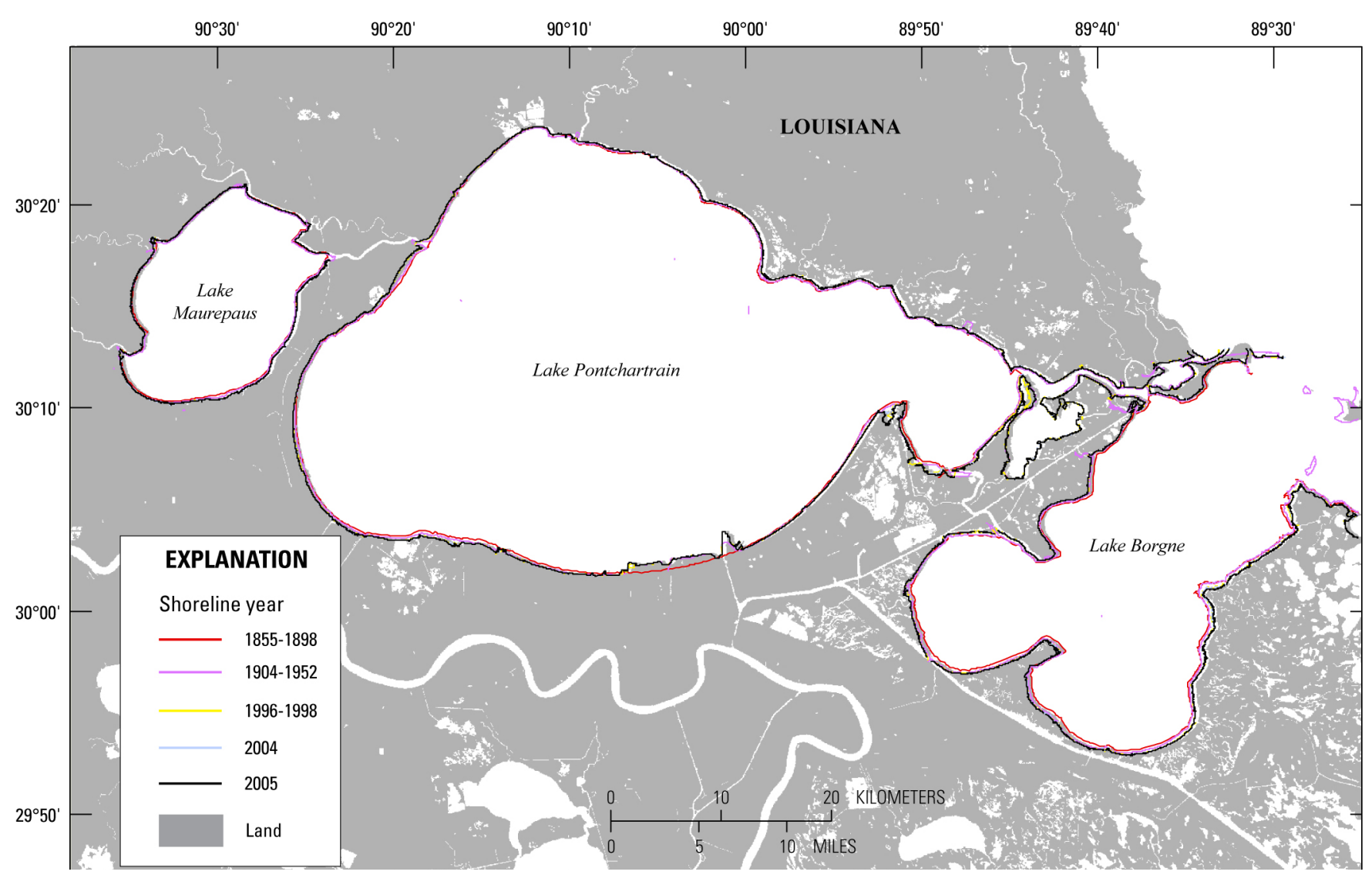

Figure 13. Map showing shoreline change around Lake Pontchartrain, Lake Borgne, and Lake Maurepaus between 1855 and 2005. Data compiled and analyzed for the BICM program, Volume 2 (modified from BICM Volume 2; Martinez, O'Brien, and others, 2009a).

A.

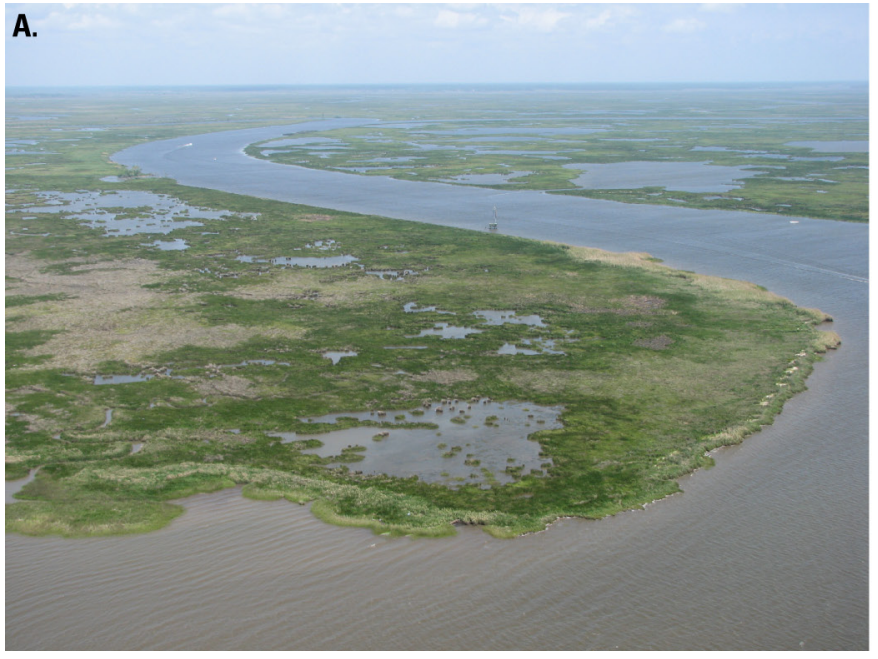

B.

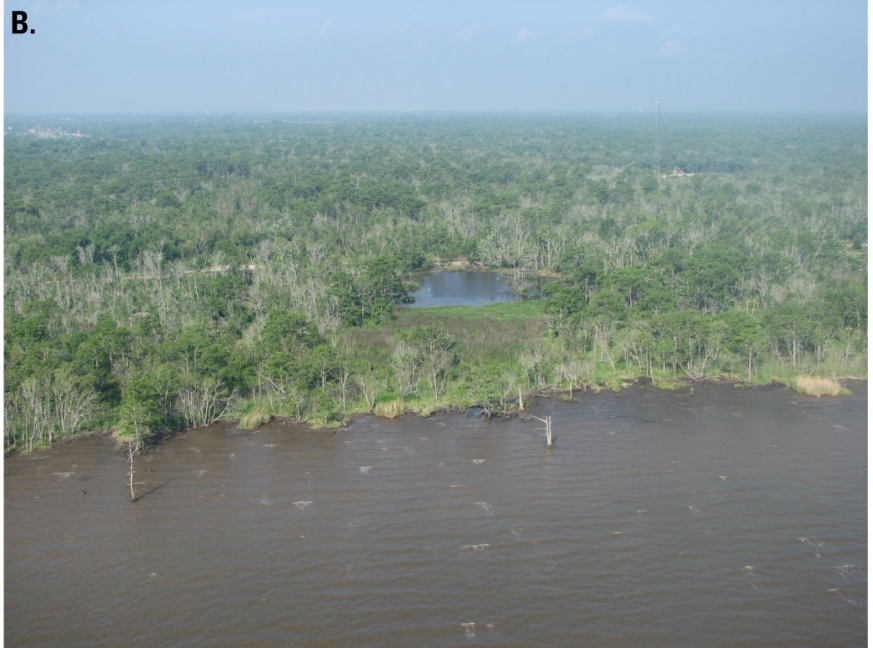

Figure 14. Aerial photos taken of the coastline within the Pontchartrain Lake Basin in 2006 as part of the BICM program: A) East Rigolets and B) Frenier Swamp areas (BICM Volume 1; Westphal and others, 2009). 


\section{Mississippi River Delta Plain}

\section{Chandeleur Islands}

The arcuate, $80-\mathrm{km}$ - (50-mi) long Chandeleur Islands (fig. 1) form the longest barrier-island chain in the northern Gulf of Mexico. The Chandeleur barrier-island system is part of the Breton National Wildlife Refuge, which extends from Hewes Point north of the Chandeleur Islands, along the ephemeral shoals of Curlew and Grand Gosier Islands, to Breton Island in the south (fig. 15). The Chandeleur Islands were formed through the erosion and reworking of the deltaic headland of the abandoned St. Bernard Delta complex (fig. 10) (Suter and others, 1988; Brooks and others, 1995). The

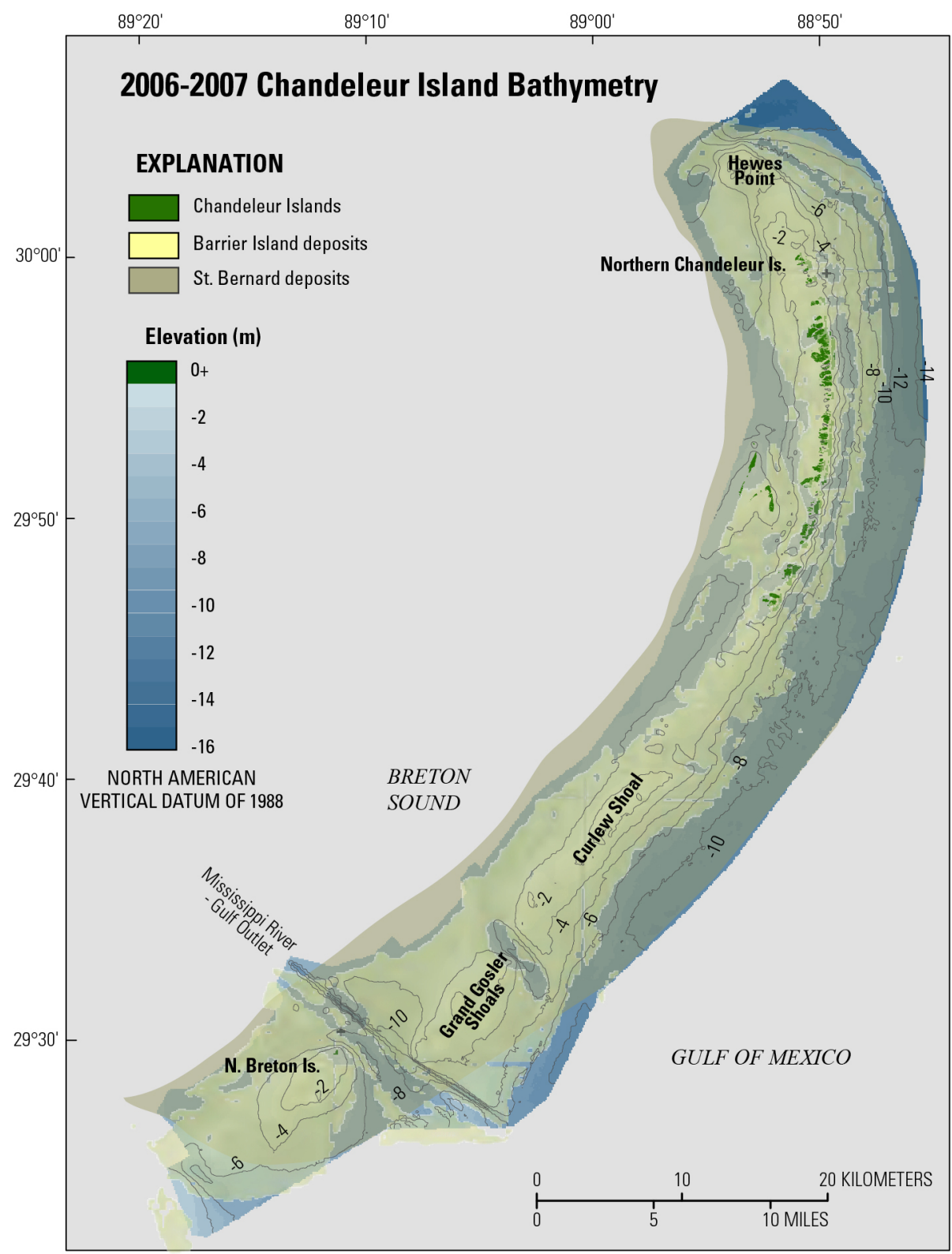

Figure 15. Bathymetric map (2006-2007) using BICM data collected in the nearshore waters around the Breton National Wildlife Refuge area. The Chandeleur Islands (green) arcuate barrier-island chain extends from Hewes Point in the north, along the islands to the ephemeral shoals of Curlew and Grand Gosier, and Breton Island in the south (modified from Flocks, Twichell, and others, 2009; Twichell and others, 2009a). Abbreviation: $m$, meter. 
delta was active from about 3,500 to 1,800 years ago (Törnqvist and others, 1996; Miner, Kulp, Weathers, and Flocks, 2009; Miner, Kulp, Weathers, Motti, and others, 2009; Rogers and Kulp, 2009). After abandonment, waves and currents concentrated the coarser-grained deltaic sediments into the Chandeleur Islands and the offshore St. Bernard Shoals. Compaction and subsidence of the muddy St. Bernard prodelta deposits, which may be greater than $35 \mathrm{~m}(115 \mathrm{ft})$ thick (Twichell and others, 2009a), and relative sea-level rise resulted in erosion and submergence of the back-barrier marsh environments such that the Chandeleur Islands are presently located about $40 \mathrm{~km} \mathrm{(25} \mathrm{mi)} \mathrm{offshore} \mathrm{of} \mathrm{the} \mathrm{Louisiana}$ mainland.

\section{History of Topographic and Bathymetric Change}

Topographic and bathymetric data collected for BICM in 2006 and 2007 were merged into a single topographicbathymetric grid (fig. 15). This dataset was compared against historical survey data from the 1870s and 1920s (fig. 16) to create bathymetric-change maps and to calculate volumes of sediment erosion and deposition around the Chandeleur Islands over the past $\sim 140$ years (fig. 6). The 2006/2007 data also serve as a baseline (post-Hurricane Katrina) for future change analyses.

The northern segment of the Chandeleur Islands (Hewes Point to Curlew Shoal) includes the highest elevations and most extensive subaerial island extents. Between the 1870s and 2006, this segment underwent net shoreface erosion of about $285 \times 10^{6} \mathrm{~m}^{3}\left(373 \times 10^{6} \mathrm{yd}^{3}\right)$. Much of the eroded sediment was deposited in the back-barrier environment (29 percent) through overwash processes or was transported north to Hewes Point (45 percent).

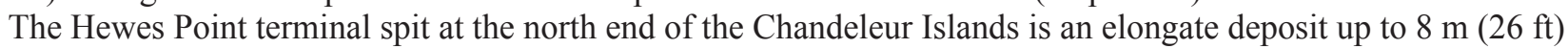
thick (fig. 17) consisting of 97 percent well-sorted, fine-grained sand that formed as the result of littoral transport of sediment into the deeper waters north of the barrier-island platform. A combination of island orientation parallel to the prevailing wave climate, a centralized source of sandy deposits, and terminal accommodation space adjacent to the St. Bernard Delta produced this unique depositional system; the approximately $258 \times 10^{6} \mathrm{~m}^{3}\left(338 \times 10^{6} \mathrm{yd}^{3}\right)$ deposit at Hewes Point is the largest sand body among the Louisiana barrier-island systems. South of Hewes Point, the Chandeleur Islands are composed of small islands separated by inlets. The islands contain dunes and overwash splays that protect back-barrier saltwater marsh and submerged aquatic vegetation. Although this is the longest section of the barrier-island arc, there is significantly less sediment than at Hewes Point because the island platform is only 1.5 to $4.2 \mathrm{~km}$ ( 0.9 to $2.6 \mathrm{mi})$ wide, and the barrier-island deposits are less than $5 \mathrm{~m}(16.4 \mathrm{ft}$ ) thick (Twichell and others, 2009a). Large parts of this section are at or below sea level and contain a veneer of sandy material.

Historically, the central section of the Chandeleur barrier-island system (Curlew and Grand Gosier shoals) underwent the greatest amount of net erosion (Miner, Kulp, FitzGerald, and Georgiou, 2009). More than $405 \times 10^{6} \mathrm{~m}^{3}$ $\left(530 \times 10^{6} \mathrm{yd}^{3}\right)$ of sediment were eroded between the 1870 s and 2007 , of which only 18 percent was deposited in the back-barrier environment. The Curlew and Grand Gosier shoals are the submerged remnants of these formerly emergent barrier islands. The Curlew - Grand Gosier platform is wider (3.7 to $12 \mathrm{~km}, 2.3$ to $7.5 \mathrm{mi}$ ) than, and about as thick as, the platform that underlies the Chandeleur Islands.

Like the shoals, Breton Island at the southern end of the Chandeleur barrier-island system has been severely reduced in size and is predominantly submerged. The Breton Island platform is 5.2 to $7.6 \mathrm{~km}$ (3.2 to $4.7 \mathrm{mi})$ wide and is also less than $5 \mathrm{~m}$ (16.4 ft) thick (Twichell and others, 2009a). Only 7 percent of the $51 \times 10^{6} \mathrm{~m}^{3}\left(68 \times 10^{6} \mathrm{yd}^{3}\right)$ that eroded historically along the shoreface was deposited in the back-barrier environment (Miner, Kulp, FitzGerald, and Georgiou, 2009). Much of the sediment loss at Breton Island can be attributed to updrift sand removal at the Mississippi River to Gulf Outlet (MRGO) shipping channel. Maintenance of the MRGO has moved up to $52 \times 10^{6} \mathrm{~m}^{3}\left(68 \times 10^{6} \mathrm{yd}^{3}\right)$ of sediment to a disposal area seaward of the island platform, depleting sediment from the natural system.

Shoreline- and seafloor-change analyses based on historical hydrographic data (since 1869), shoreline surveys (since 1855), and satellite imagery for the Chandeleur Islands reveal long-term trends of barrier-island shoreface retreat, platform thinning, and, recently, barrier-island disintegration. Volume calculations indicate that sediment was deposited downdrift (northward) and seaward at the Hewes Point terminal spit over the past 125 years. A similar volume of sediment accreted at the extreme southern limits of the island chain. The volume deposited in the back barrier, however, is only half that distributed to the flanks, indicating that the dominant transport mode is alongshore as opposed to cross-shore. The depositional sinks at the flanks of the island arc accreted at rates of more than $1 \times 10^{6} \mathrm{~m}^{3} / \mathrm{yr}\left(1.3 \times 10^{6} \mathrm{yd}^{3} / \mathrm{yr}\right)$ between 1870 and 2007; however, calculations of potential alongshore sediment-transport rates based on 20 years of offshore wave data are two orders of magnitude less than the accretion rates. The sediment sources for these accretionary zones at the flanks include (1) relict deltaic deposits that have eroded from the shoreface since 1870 and (2) nearshore and subaerial barrier-island sand. (For more detailed discussion on volumetric changes, see Theme 2, this report.) 


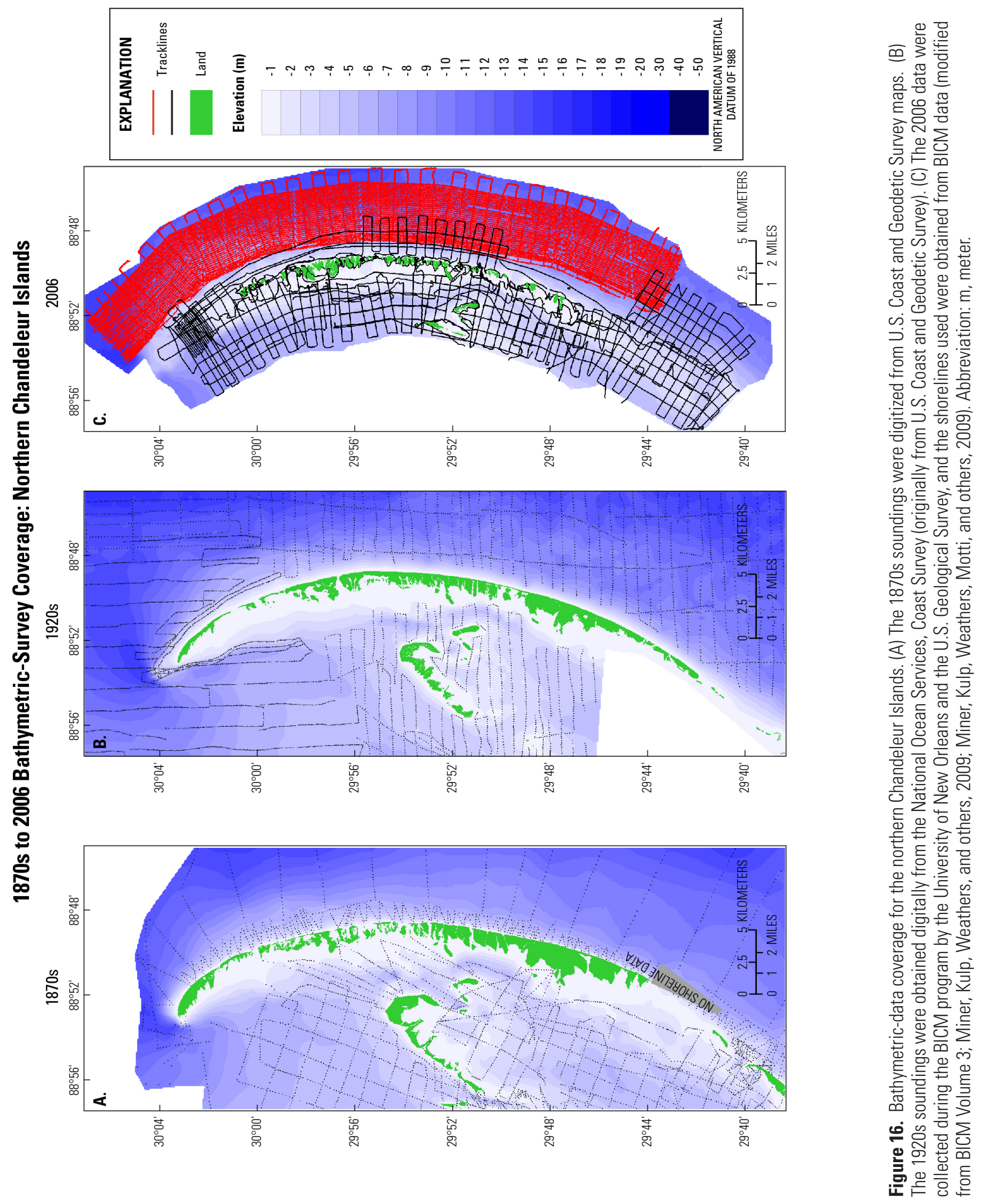




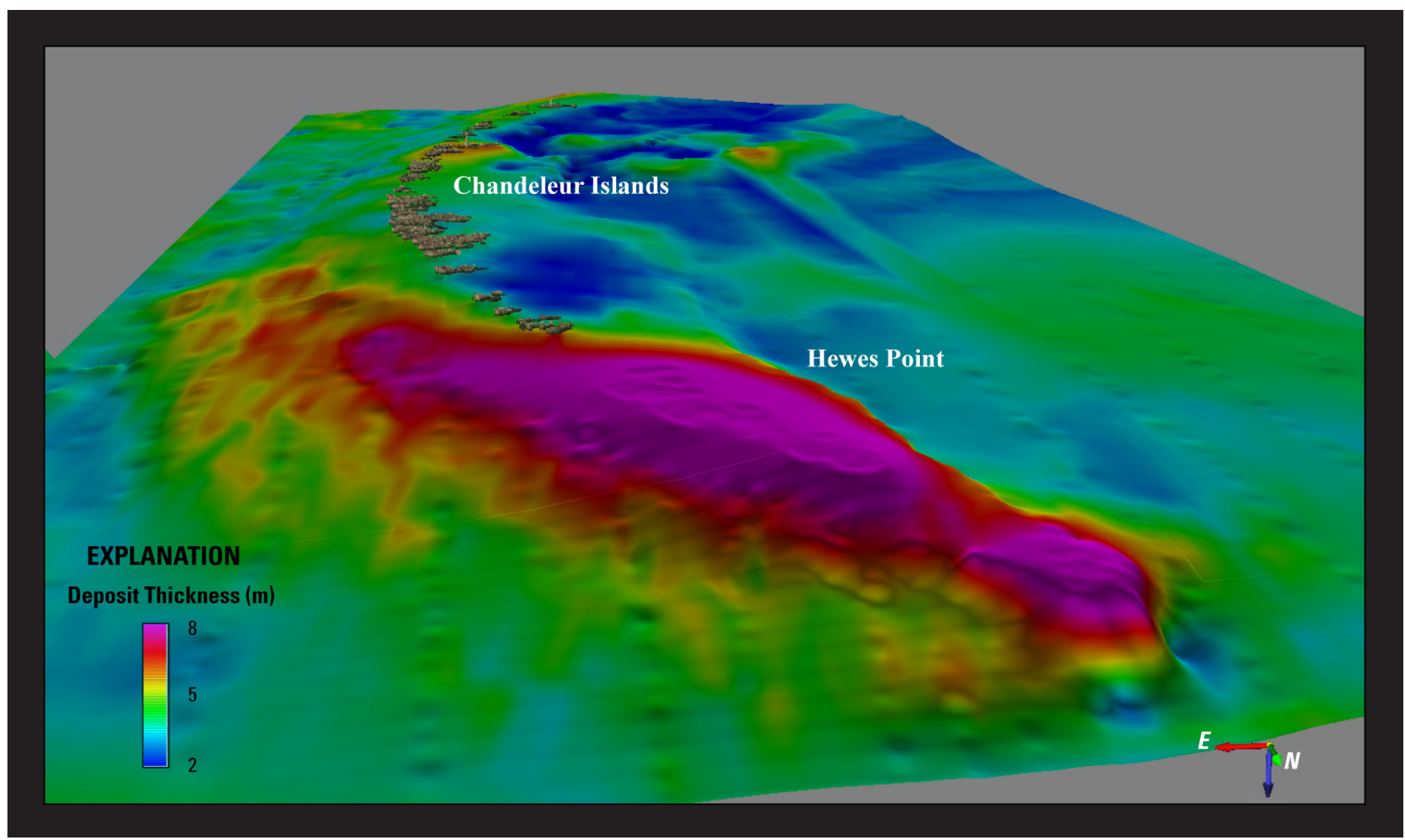

Figure 17. Sediment isopach of Hewes Point terminal spit; deposit (purple and red) is approximately $27 \mathrm{~km}^{2}\left(10 \mathrm{mi}^{2}\right), 8 \mathrm{~m}(26.3 \mathrm{ft})$ thick, and is composed of 97 percent well-sorted fine sand (modified from Flocks and others, 2011). Abbreviation: m, meter.

\section{Habitat Change}

Analysis of BICM habitat data from 1998, 2002, 2004, and 2005 indicated that even prior to Hurricane Katrina, the distribution of habitat types on the Chandeleur Islands varied between analyses, and significant changes occurred following the passage of Hurricane Katrina in 2005. For example, after Hurricanes Isidore and Lili impacted the area in 2002, about half of the land area on Breton Island (figs. 18a and 19) and almost all of Grand Gosier and Curlew Islands were converted to open water (Fearnley, Brien, and others, 2009b). All three islands had recovered slightly by 2004, but all habitat types on Breton, Curlew, and Grand Gosier Islands were converted to open water in 2005 (fig. 19) following the passage of Hurricane Katrina (Fearnley, Brien, and others, 2009d).

Compared with the southern and central islands (Breton to Curlew Islands), the total habitat acreage on the northern Chandeleur Islands was relatively stable from 1998 to 2004 (fig. 19). In 2001, specimens of Spartina alterniflora (smooth cordgrass) were planted on 10 overwash fans on the northern islands as part of the Chandeleur Islands Marsh Restoration Project (PO-27; LCWCRTF, 2004). These plantings and higher island elevations may have helped to mitigate the impacts of Hurricanes Isidore and Lili in this area. Like Breton, Grand Gosier, and Curlew Islands, the northern Chandeleur Islands were significantly impacted by Hurricane Katrina; in the 2005 analysis, all habitat types except some marsh areas were converted to open water (figs. 18b and 19).

\section{Impacts of Storms}

Presently, the Chandeleur Islands are experiencing a very high RSLR ( $>4$ millimeter per year $[\mathrm{mm} / \mathrm{yr}] ;>0.16$ inch per year [in/yr]; Twichell and others, 2009b) and are undergoing extreme subaerial deterioration due to the combined effects of compaction of the underlying St. Bernard prodelta deposits, eustatic sea-level rise, and multiple impacts by tropical storms in the past decade. Recent storm activity has had the most significant impact on the subaerial extent of the Chandeleur Islands, and researchers have documented an increasing inability of this barrier-island chain to recover from storm-induced breaching and dune erosion (fig. 7). Tropical storms can cause rapid land loss, and major events drive 


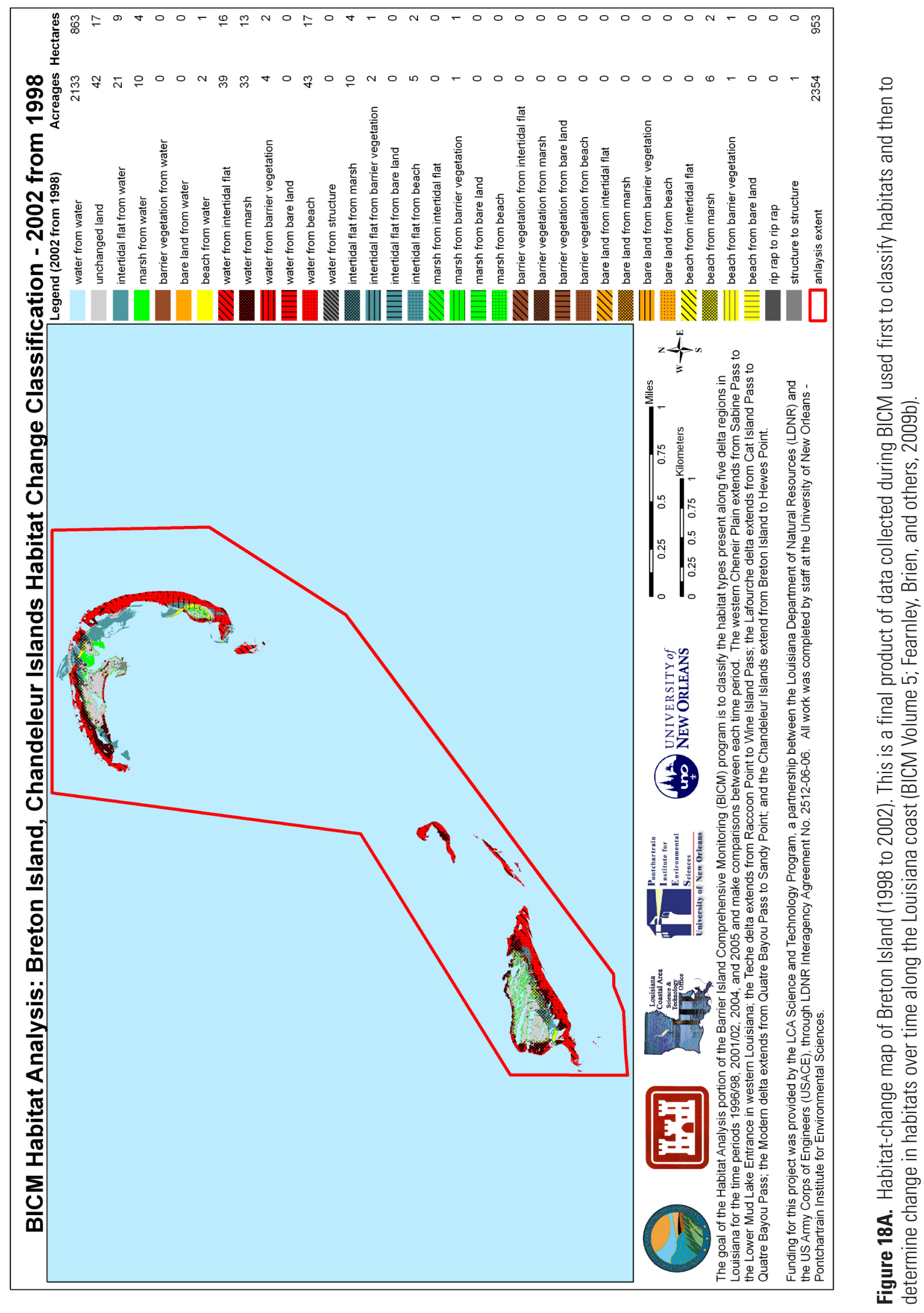




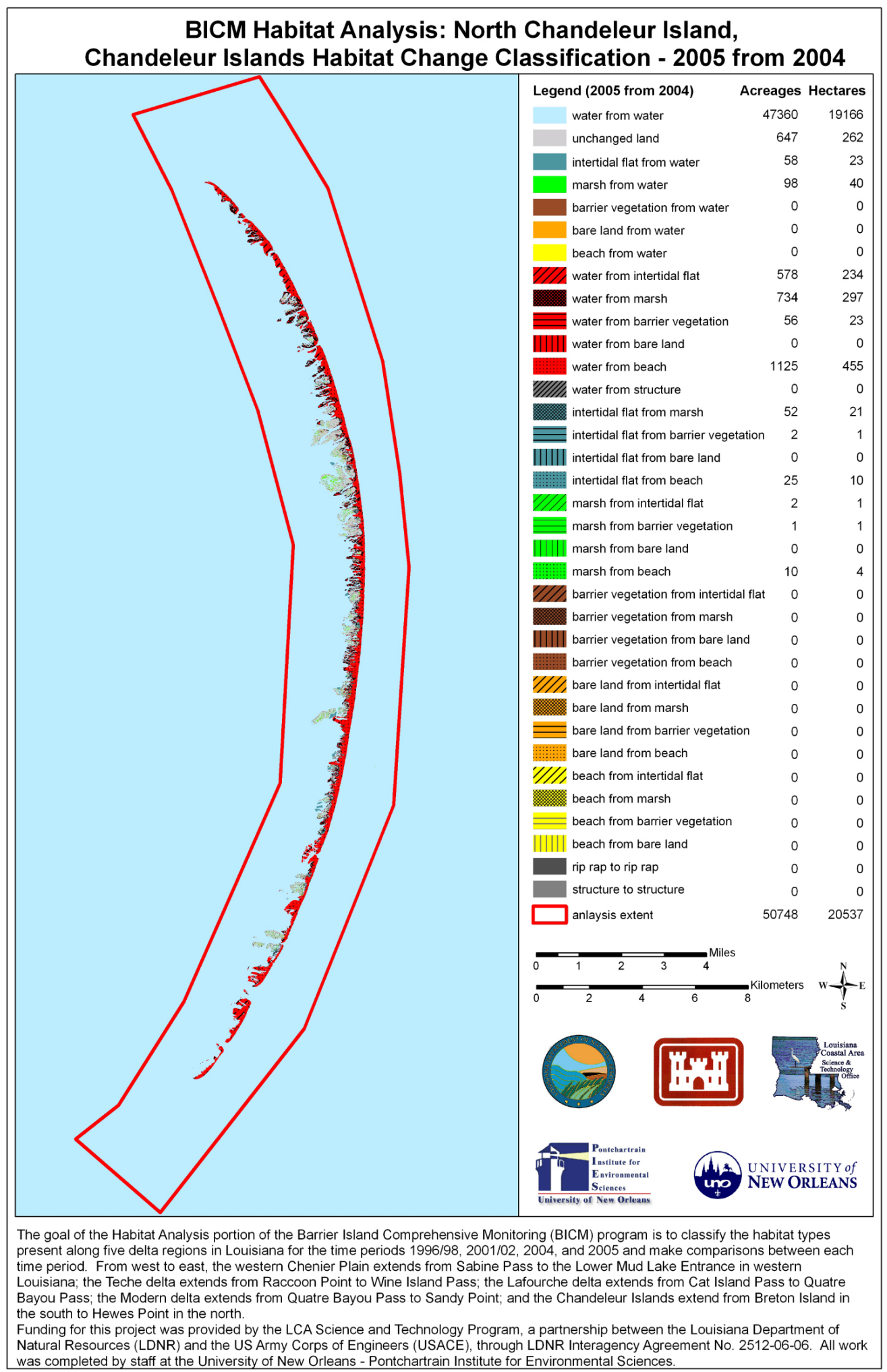

Figure 18B. Habitat-change map of the Chandeleur Islands (2004 to 2005) — note the large areas of habitat change to water after passage of Hurricane Katrina. This is a final product of data collected during BICM used first to classify habitats and then to determine change in habitats over time along the Louisiana coast (BICM Volume 5; Fearnley, Brien, and others, 2009b). 
A.

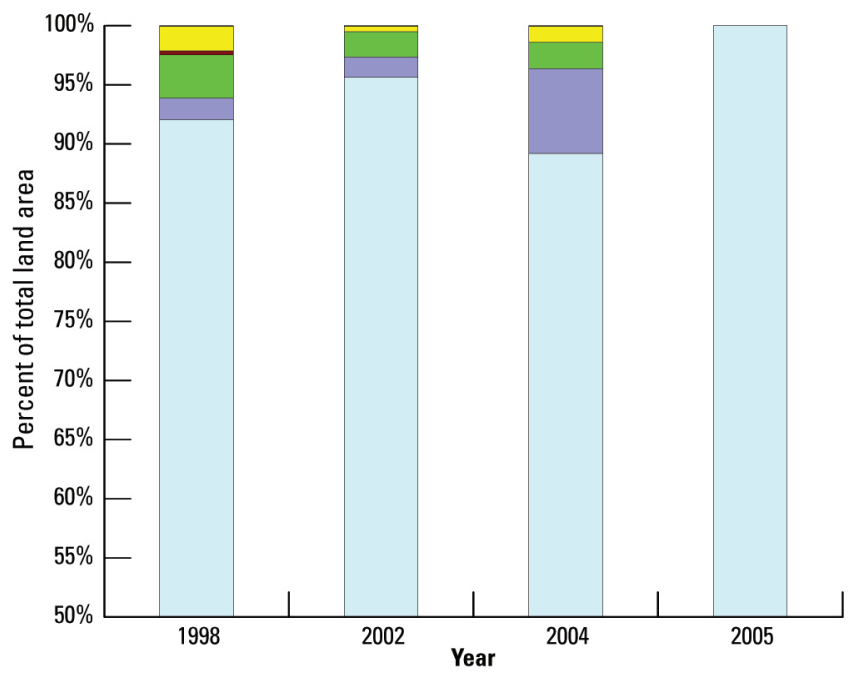

C.

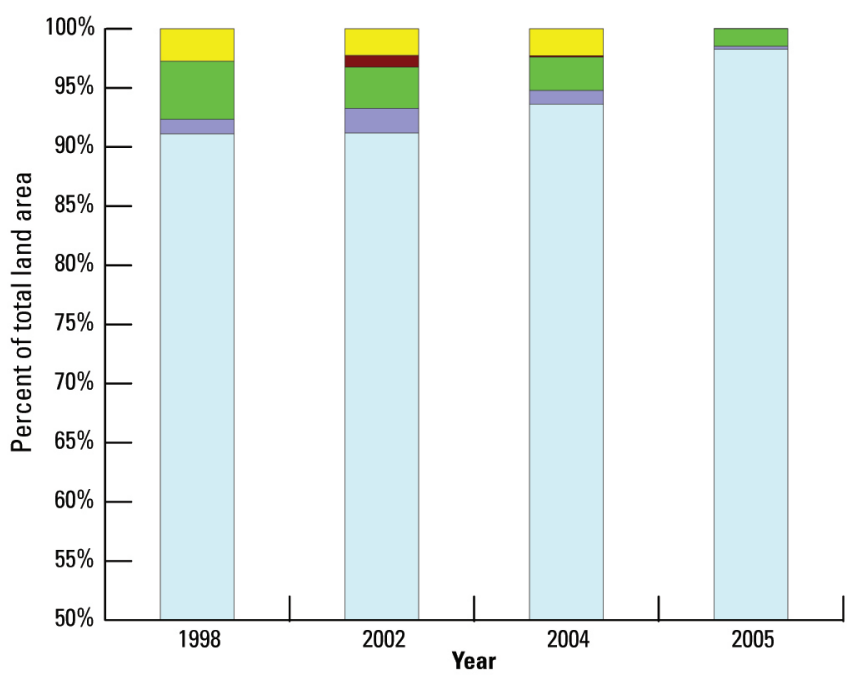

B.

CURLEW AND GRAND GOSSIER ISLANDS

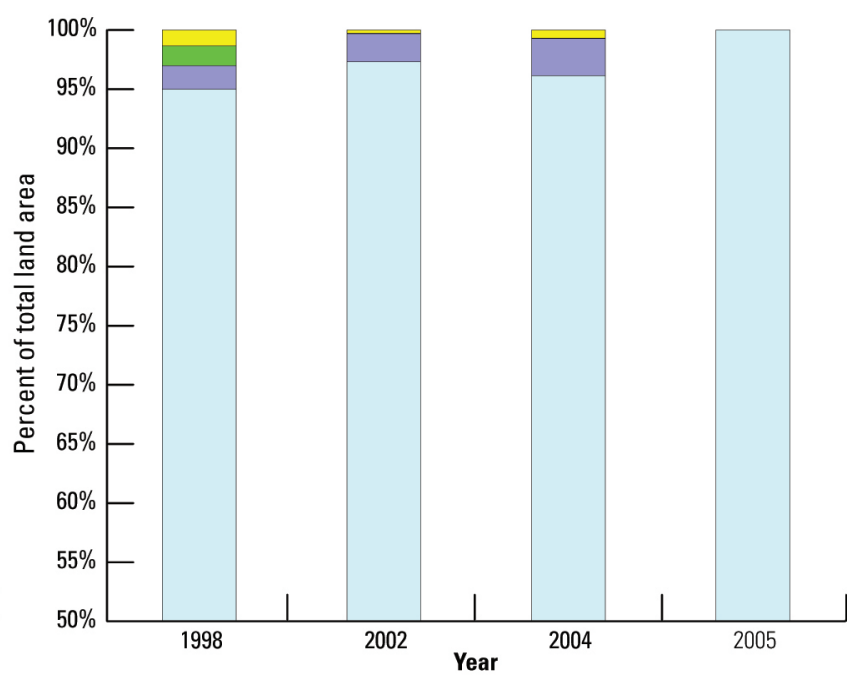

Figure 19. Cumulative percentage histograms of habitat change in analysis areas during the four analyses time periods: (A) Breton Island analysis area totals $9.3 \mathrm{~km}^{2}$ or 2,354 ac. (B) Curlew and Grand Gosier Islands analysis area totals $44.9 \mathrm{~km}^{2}$ or $11,089 \mathrm{ac}$. (C) North Chandeleur Island analysis area totals $205.4 \mathrm{~km}^{2}$ or 50,748 ac. (modified from BICM Volume 5; Fearnley, Brien, and others, 2009d).

long-term shoreline erosion and transgressive submergence of the barrier-island chain. For example, only the vegetated back-barrier-marsh platforms remained emergent following the passage of Hurricane Katrina in 2005. Subsequently, a sandy beach reformed seaward of the marsh platform; however, the shoreline retreated landward by tens of meters, and the total emergent land area was significantly reduced compared with pre-Katrina conditions (fig. 20). The impact of tropical storms on the Chandeleur Islands is discussed in greater detail in Theme 2.

Modern Delta, Lafourche, and Teche Deltas

The Modern Delta BICM study area extends from Quatre Bayou Pass east to Sandy Point in Plaquemines Parish on the west flank of the Mississippi Balize (Birdsfoot) Delta and includes the Chaland Headland, Bay Joe Wise, Shell 
Island, Scofield, and Sandy Point (fig. 1). The Modern Delta, as defined for the BICM study, makes up only a small portion of the Balize Delta and is part of a continuous shoreline extending from Raccoon Point in Terrebonne Parish to Sandy Point; therefore, it will be discussed with the Lafourche and Teche Deltas.

The south-central Louisiana coastline that includes the Teche, Lafourche, and Modern Deltas forms a 165-km (102-mi) stretch of barrier shoreline that extends from Raccoon Point in the west to Sandy Point in the east. The study area consists of a series of barrier islands and two erosional headlands (fig. 1) that extend approximately $10 \mathrm{~km}(6.2 \mathrm{mi})$ seaward of the Gulf shoreline and approximately $2 \mathrm{~km}(1.2 \mathrm{mi})$ landward of the back-barrier shoreline.

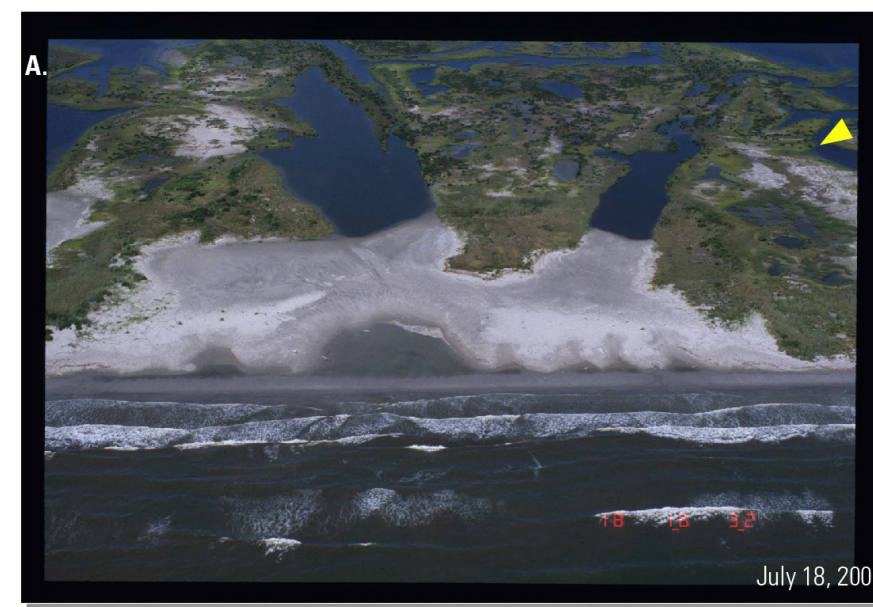

Chandeleur

Islands

2001

(courtesy USGS)

and

$2005 / 2007$

BICM photo pair
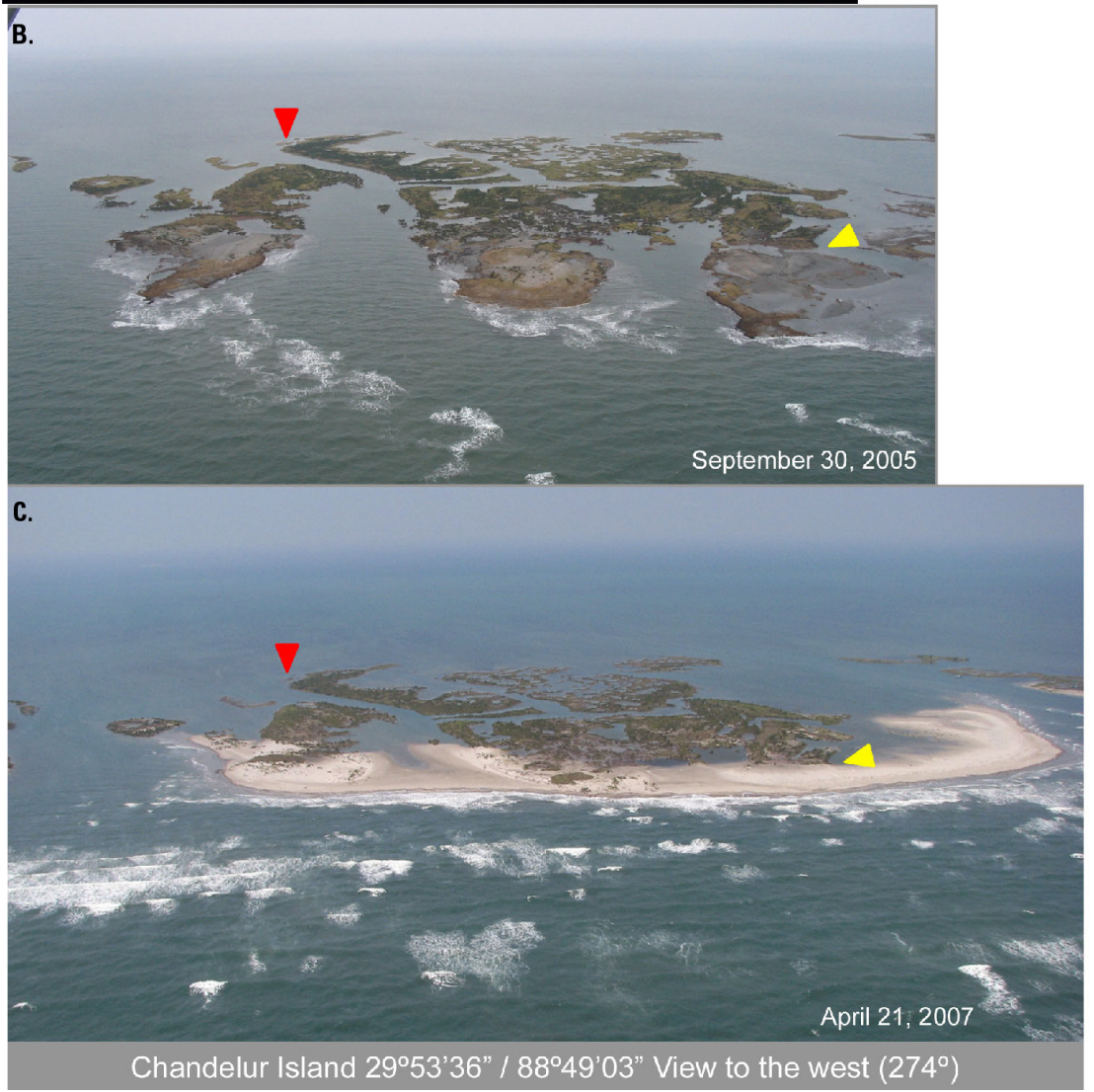

Figure 20. Oblique aerial-photo time series of a portion of the Chandeleur Islands: top photo is from July 18, 2001 (courtesy, USGS), middle photo is one day after Hurricane Katrina, and bottom photo is 22 months after Hurricane Katrina. Arrows denote same geographical location (BICM Volume 1; Westphal and others, 2009). 
The rapidly eroding Caminada Headland is a remnant of the Bayou Lafourche delta lobe that was active from about 1,500 years to 800 years B.P. (before present) (Frazier 1967; Miner, Kulp, Penland, and others, 2009). After abandonment, sediments eroded from the subsiding headland were redistributed, forming the transgressive Timbalier Islands and Grand Isle barrier systems west and east of Bayou Lafourche, respectively (Penland and Boyd, 1985; Penland and others, 1988; Jaffe and others, 1997). West and east of the Timbalier Islands and Grand Isle, the Isles Dernieres and Barataria Bight shorelines formed as the result of earlier deltaic progradation and abandonment cycles associated with the Lafourche (3,500-4000 years B.P.) and St. Bernard (3,500-2,000 years B.P.) delta complexes, respectively (fig. 10; Frazier 1967; Kulp and others, 2005). These shorelines also receive sediment transported downdrift from the eroding Caminada Headland. The Plaquemines shoreline east of the Barataria Bight was constructed by sediment eroded from the modern Balize delta lobe (1,000 years B.P. to present) as well as reworked sediment transported alongshore from the western Chaland Headland (Frazier 1967; Penland and Boyd 1985; Penland and others, 1988; Kulp and others, 2005; Miner, Kulp, FitzGerald, Flocks, and Weathers, 2009).

\section{History of Topographic and Bathymetric Change}

High rates of RSLR ( $\sim .9$ (centimeter per year [cm/yr], $0.35 \mathrm{in} / \mathrm{yr}$ ) coupled with storm-induced current and wave erosion have led to a large deficit in the coastal-sediment budget along the Teche-Lafourche and Plaquemines shorelines, which is forcing barrier-shoreface retreat along the periphery of the Terrebonne and Barataria Basins of the Mississippi River Delta Plain. One of the impacts associated with higher rates of RSLR is the conversion of interior wetlands to open water, leading to increased bay tidal prism. The increase in tidal prism results in degradation of the barrier islands by inlet widening, the formation of new inlets, and sediment sequestration in ebb-tidal deltas. In 2006, BICM sponsored nearshore single-beam bathymetric surveys (fig. 21) from Raccoon Point to Sandy Point. These data were integrated with historical bathymetry from three time periods (1880s, 1930s, and 1980s) to construct a series of digital elevation models that were used to calculate sediment volumetric changes and determine long-term erosional and depositional trends (Miner, Kulp, Penland, and others, 2009). Miner, Kulp, Penland, and others (2009) identified several predominant trends during the 125year period, including (1) shoreface erosion of $\sim 1.6 \times 109 \mathrm{~m}^{3}\left(2.1 \times 109 \mathrm{yd}^{3}\right)$ that forced $\sim 3 \mathrm{~km}(\sim 1.9 \mathrm{mi})$ of shoreface retreat, (2) sediment deposition in coastal bights and enlargement of ebb-tidal deltas, and (3) a combined increase in tidal inlet cross-sectional area from $\sim 41,400$ to $\sim 139,500$ square meters $\left(\mathrm{m}^{2}\right)\left(\sim 45,514\right.$ to $\sim 166,841$ square yards $\left.\left[\mathrm{yd}^{2}\right]\right)$. Despite the observed sedimentation in coastal bights and ebb-tidal deltas, only $\sim 14$ percent of the eroded sediment volume was deposited within the study area. Miner, Kulp, Penland, and others (2009) also analyzed bathymetric and shoreline change datasets separated by shorter time (sub-annual) periods, demonstrating that long-term trends are driven by processes associated with major hurricane impacts, and rates of shoreface erosion are an order of magnitude greater during active hurricane seasons compared to long-term trends.

. The majority ( $\sim 89$ percent) of the total erosion in the study area occurred along the shorefaces of the Isles Dernieres, Caminada Headland, and Plaquemines shorelines. By comparing the volume eroded per unit area of these three shoreface zones, Miner, Kulp, Penland, and others (2009) showed that the Caminada Headland underwent the greatest amount of erosion -3.4 cubic meters per square meter $\left(\mathrm{m}^{3} / \mathrm{m}^{2}\right)\left(4.5\right.$ cubic yards per square yard $\left.\left[\mathrm{yd}^{3} / \mathrm{yd}^{2}\right]\right)$ relative to -2.1 and $-1.7 \mathrm{~m}^{3} / \mathrm{m}^{2}\left(-2.75\right.$ and $\left.-2.2 \mathrm{yd}^{3} / \mathrm{yd}^{2}\right)$ for the Isles Dernieres and Plaquemines shoreface zones, respectively. They measured an approximate maximum vertical erosion of $-10 \mathrm{~m}(32.8 \mathrm{ft})$ along the Caminada Headland, $-5 \mathrm{~m}(16.4 \mathrm{ft})$ along the Isles Dernieres, and $-6(19.7 \mathrm{ft}) \mathrm{m}$ along the Plaquemines shoreline. Erosion was not limited to the nearshore and upper shoreface; rather, a significant portion of the total shoreface erosion occurred along the lower shoreface and extended offshore beyond the limits of the study area (fig. 22).

In addition to shoreface erosion, scour at tidal inlets accounted for $\sim 6$ percent of the total erosion that occurred in the study area between the 1880s and 2006 (Miner, Kulp, Penland, and others, 2009). Processes that contribute to tidal inlet scour include (1) landward migration of inlet throats, (2) lateral inlet channel migration, (3) inlet throat deepening and widening, and (4) barrier breaches that remain open, forming new tidal inlets. For a more detailed discussion of hydrodynamic processes in Barataria Basin, see Theme 4 in this report.

The observed landward scouring and seaward shoaling of tidal inlets along the Teche-Lafourche coasts line resulted in high rates of shoreline and shoreface retreat in the study area (Miner and others, 2007; Miner, Kulp, Motti, and others 2009). The highest rates of inlet landward migration occurred along the Timbalier Islands. Raccoon Pass migrated landward at a rate of $29 \mathrm{~m} / \mathrm{yr}(95 \mathrm{ft} / \mathrm{yr})$ since the 1880s, and Little Pass Timbalier migrated landward at a rate of $44 \mathrm{~m} / \mathrm{yr}$ (144 ft/yr) since the $1930 \mathrm{~s}$.

Lateral inlet migration in the study area was driven by lateral spit accretion as the barrier island migrated across a former inlet location (Miner, Kulp, Motti, and others, 2009). Because of the high rates of shoreline retreat, lateral 


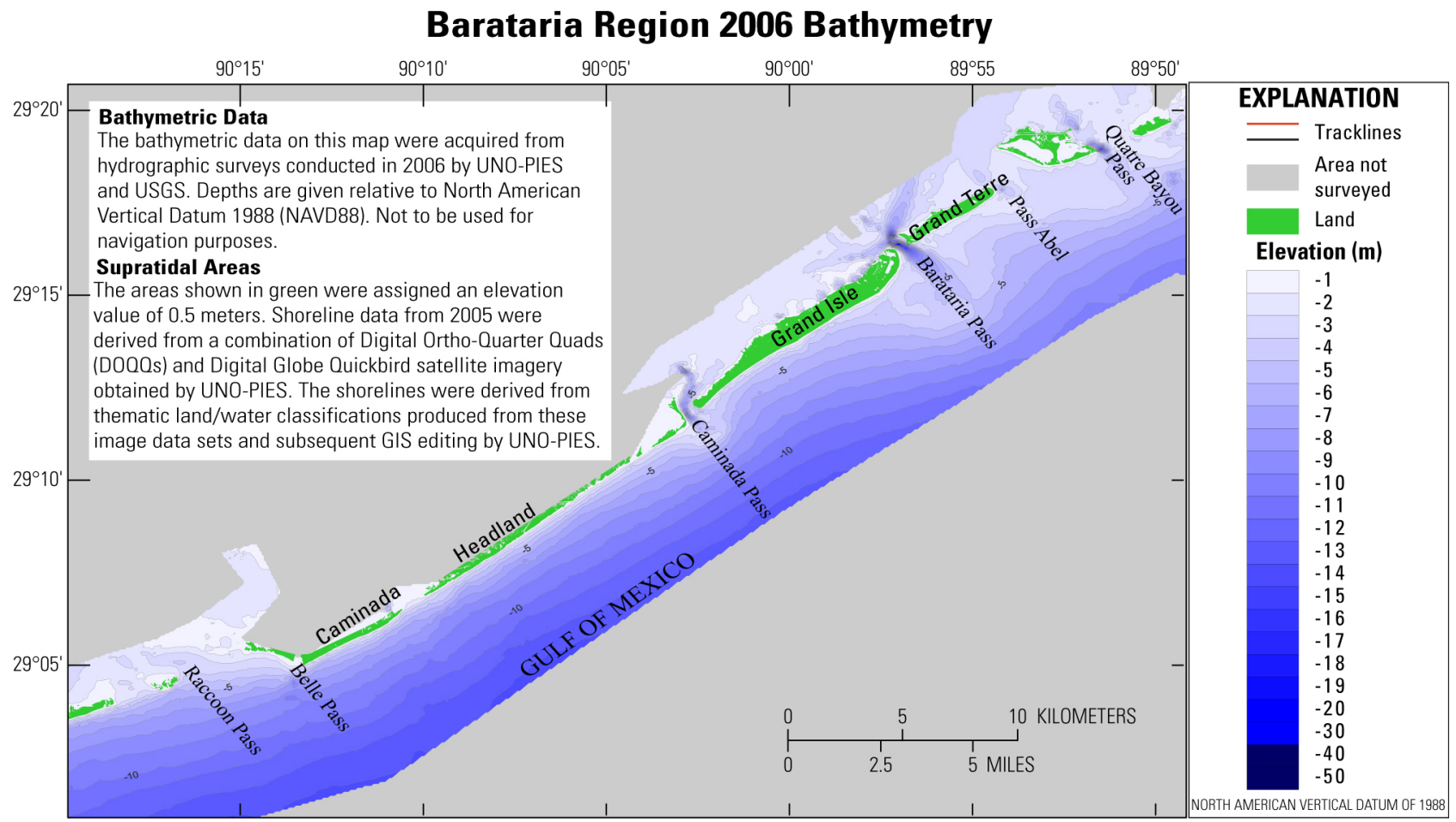

Figure 21. Bathymetry (gray increasing water depth to darker blue) collected during the BICM project in 2006 along Caminada Headland, Grand Isle, and Grand Terre. Barrier extents are indicated by green with shorelines derived from thematic classifications produced from image datasets and GIS editing (modified from BICM Volume 3; Miner, Kulp, Weathers, Motti, and others, 2009). Abbreviation: $\mathrm{m}$, meter.

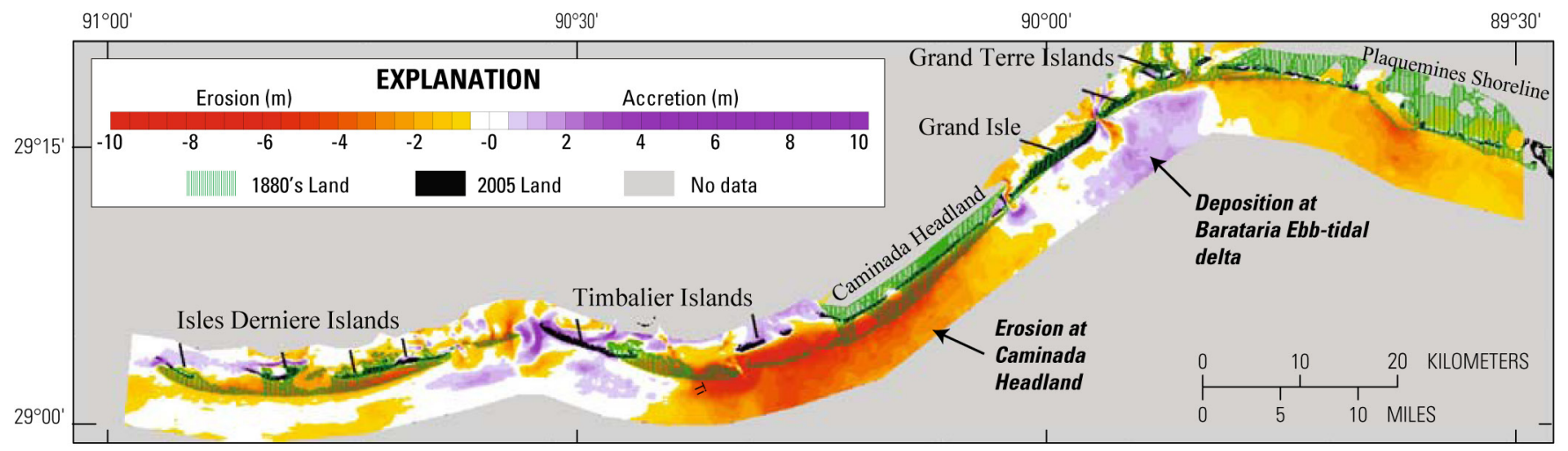

Figure 22. Seafloor-change map of the Raccoon Point to Sandy Point area from the 1880s to 2005. High erosion occurs along the Isles Dernieres, Caminada, and Plaquemines shorelines, with deposition occurring at the tidal passes. The 2005 bathymetry data collected during BICM (BICM Volume 3; Miner, Kulp, Motti, and others, 2009) were compared with 1880s bathymetry from List and others (1994) and with shoreline data analyzed for the BICM program (modified from BICM Volume 2; Martinez, O'Brien, and others, 2009a). Abbreviation: $\mathrm{m}$, meter. 
migration is often accompanied by landward migration. The only tidal inlet where lateral migration dominated the morphologic evolution of the barrier system was at Cat Island Pass, where Timbalier Island has migrated $>8 \mathrm{~km}(5 \mathrm{mi})$ to the west since the 1880s (figs. 22 and 23).

Barras (2006) reported that interior wetland loss in the Barataria and Terrebonne Basins inland of the TecheLafourche shoreline occurred at a rate of $\sim 16 \mathrm{~km}^{2} / \mathrm{yr}\left(6.2 \mathrm{mi}^{2} / \mathrm{yr}\right)$ for the period 1956 to 2004. Several studies have documented increased historical tidal prisms along coastal Louisiana resulting from increased mainland open-water areas. The greater water volumes passing through the tidal inlets during each tidal cycle deepen and enlarge existing inlets and contribute to the formation of additional stable inlets along the barrier shoreline (FitzGerald and others, 2004, 2007; Miner and others, 2007; Howes, 2009). Between the 1880s and 2006, the combined tidal inlet cross-sectional area increased more than threefold in the study area (see Theme 4; Howes, 2009), and the number of tidal inlets have increased from 13 to about 25. During this same time period, the combined barrier island footprint decreased in area from 81 to $25 \mathrm{~km}^{2}(31$ to $10 \mathrm{mi}^{2}$ ) (Martinez, O'Brien, and others, 2009a).

Increasing the tidal prism also increases the efficiency of sediment trapping in ebb-tidal deltas (Walton and Adams, 1976; FitzGerald and others, 2004, 2007; Miner and others, 2007), increasing their sediment volume and extent. Although local ebb-tidal delta progradation is apparent at most inlets, the ebb-tidal deltas at coastal bights are the primary long-term sediment sinks. This is because more sediment was lost due to shoreface erosion at these locations than was deposited at ebb-tidal deltas, causing shoreface retreat at the terminal lobes of the ebb tidal deltas (Miner, Kulp, Motti, and others, 2009).

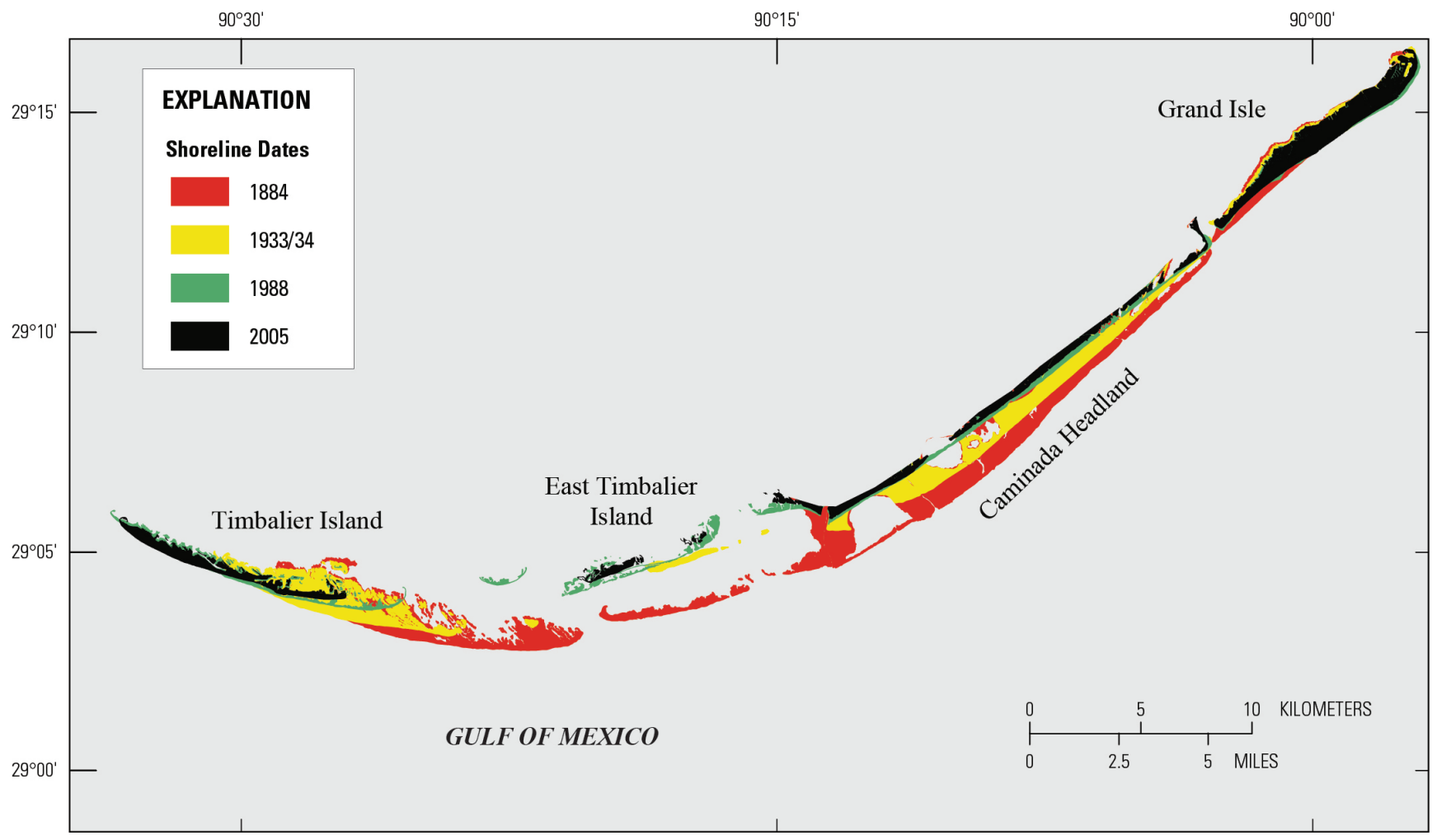

Figure 23. Historical (from 1884 to 2005) shoreline-change time series of Timbalier Island, Caminada Headland, and Grand Isle using shoreline data compiled from BICM Volume 2 (modified from BICM Volume 2; Martinez, O'Brien, and others, 2009a). Note shoreline retreat and land loss of Caminada Headland and westward migration and land loss of Timbalier Island. 
Mississippi River Delta Plain

\section{Habitat Change}

BICM habitat data for 1998, 2001, 2004, 2005 were compared along the Teche, Lafourche, and Modern Delta shorelines. This portion of the Louisiana coast has a long history of being engineered to help maintain its form and structure, and many of the observed habitat changes were directly related to these restoration efforts. The most common construction projects typically place large amounts of dredge material (primarily fine-grained sand) on the shoreface to enhance beach width and elevation. Another common shoreface protection method was used at Raccoon Island, where eight concrete breakwaters were constructed in 1997 along the nearshore and eight more were constructed in 2008-09. Some projects also emplaced fine-grained material on the bayside of islands to provide substrate for back-barrier marsh environments.

Habitat change in response to barrier island restoration varies; the following examples describe some of the changes that occurred post construction and also how hurricanes impacted those habitats. The Whiskey Island Restoration project (TE-27; LCWCRTF, 2002a) was completed in 2002 and showed that although the overall acreages of bare land and intertidal flat habitats increased as a result of dredge material emplacement, there was a slight decrease in marsh habitat acreages as a result of burial. By 2004, plants had begun to colonize the placed material and the acreages of barrier vegetation increased as acreages of bare land decreased. Marsh habitat acreage remained relatively stable, indicating that the placed material was colonized by dune and other non-wetland species rather than marsh grass - a result of the increased elevation of the placed material. Storm surge associated with Hurricanes Katrina and Rita caused significant washover at Whiskey Island, increasing the acreages of beach and intertidal flat habitat (figs. 24 and 25). The extent of marsh habitat at Whiskey Island remained relatively unchanged after the passage of Hurricanes Katrina and Rita.

The 1997 breakwater construction at Raccoon Island (TE-29; LCWCRTF, 2002b) increased the intertidal flat habitat acreage behind the structures by 2004 (fig. 25). Between 1996 (pre-construction of breakwaters) and 2004, marsh plants colonized the newly accumulated intertidal flats, increasing the acreages of marsh habitat. Significant overwash resulting from Hurricanes Katrina and Rita in 2005 deposited sandy sediment on Raccoon Island and increasing the acreages of beach and intertidal flat habitat while decreasing the acreages of marsh habitat for the 2005 analysis period.

Similar restoration projects have been constructed on Trinity and East Islands (Teche Delta) and Timbalier and East Timbalier Islands, Caminada Headland, Grand Isle, and Grand Terre and East Grand Terre Islands (Lafourche Delta). In most cases, dredged material was emplaced to create terraces, dunes, and marsh (LCWCRTF, 2002c, 2002d), resulting in increased acreages of bare land. Following the passage of Hurricanes Katrina and Rita, beach and overwash habitat generally increased at these locations. Planting native flora, such as Spartina patens and Panicum armanum, and placement of sand fencing also helped to create dunes (LCWCRTF, 2002c). Construction of breakwaters along Grand Isle, as well as numerous placements of sand for beach nourishment, has helped to maintain land acreages. The placement of dredge material and vegetative plantings on Grand Terre created 127 acres of land in the eastern portion of the island (LCWCRTF, 2008).

\section{Impacts of Storms}

Using data collected during the BICM program, Miner, Kulp, Motti, and others (2009) and Miner, Kulp, FitzGerald, and Georgiou (2009) analyzed the impact of storms on the Teche, Lafourche, and Modern Delta coastline. The following summarizes these results.

Bathymetric data collected in July 2005 (DeWitt and others, 2007) were compared to the BICM data collected in June 2006 (fig. 26) to assess the impact of storms on the Caminada Headland shoreface and compare long-term sediment transport volumes with short-term sediment transport resulting from extreme storms. In order to assess the impact of three hurricanes that impacted the area in 2005 (Hurricanes Cindy, Katrina, and Rita; Knabb and others, 2005, 2006; Stewart, 2006), the 2006 survey reoccupied the same transects as the 2005 survey. Miner, Kulp, Penland, and others (2009) showed that between 2005 and 2006, the maximum vertical erosion $(\sim 1 \mathrm{~m} ; \sim 3.28 \mathrm{ft})$ occurred in water depths $>8 \mathrm{~m}(26 \mathrm{ft})$ along the lower shoreface (fig. 26). The volume of sediment eroded from the Caminada Headland shoreface and nearshore environments was $8.94 \times 107 \mathrm{~m} 3(11.69 \times 107 \mathrm{yd} 3)$ from a $1.55 \times 108 \mathrm{~m} 2(1.85 \times 108 \mathrm{yd} 2)$ area. The long-term (1880s to 2006) average rate of erosion for the same area was $\sim 2.4 \times 106 \mathrm{~m} 3 / \mathrm{yr}(\sim 3.14 \times 106 \mathrm{yd} 3 / \mathrm{yr})$. Shoreline straightening and equilibrium occurs during post-storm redistribution of sediment from nearby shorelines by littoral transport processes (fig. 27). Redistribution of sediment readily occurs especially when nearby islands have recently been nourished providing an available sediment source. 


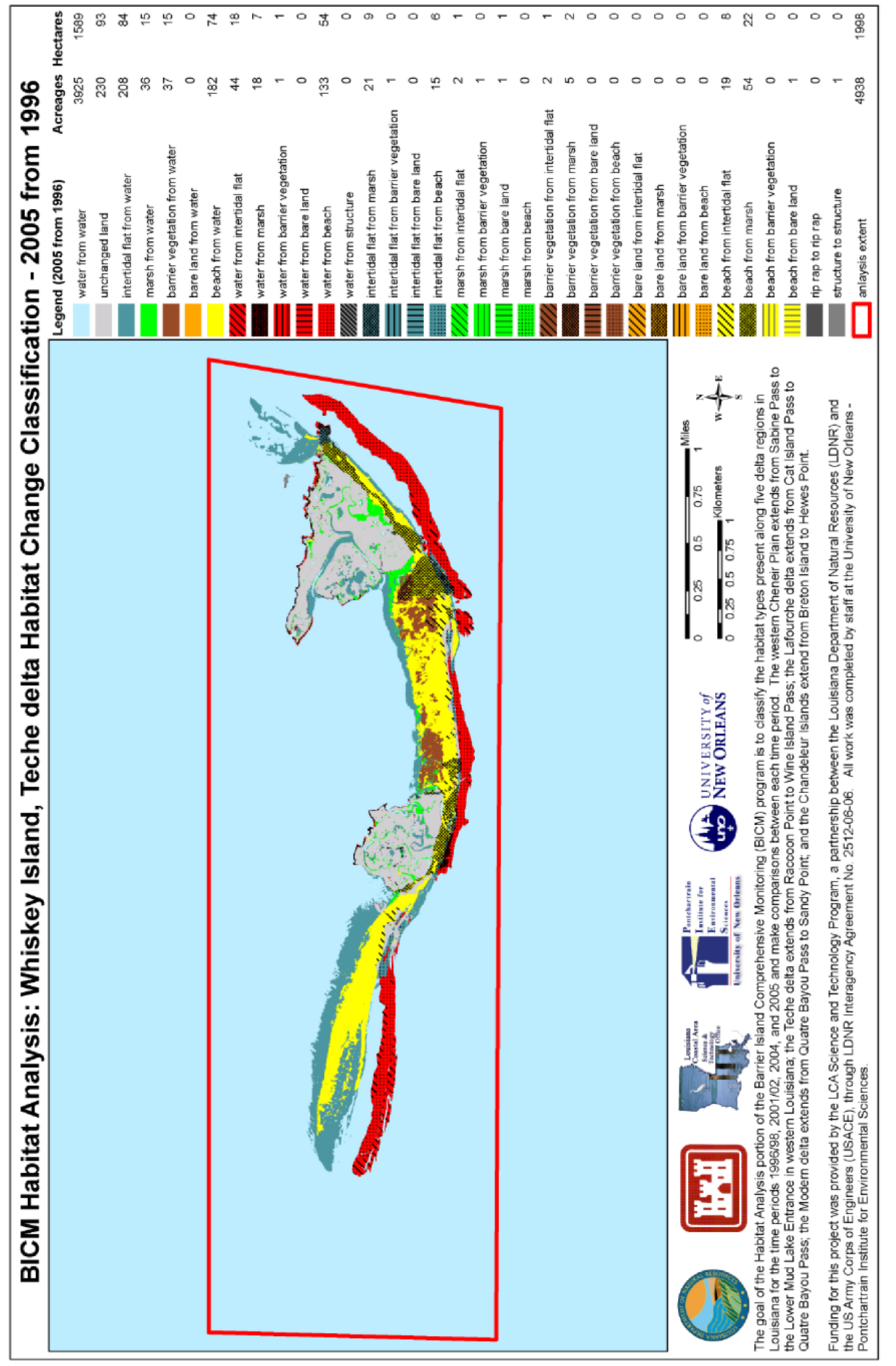

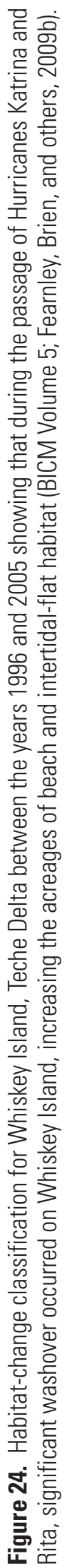



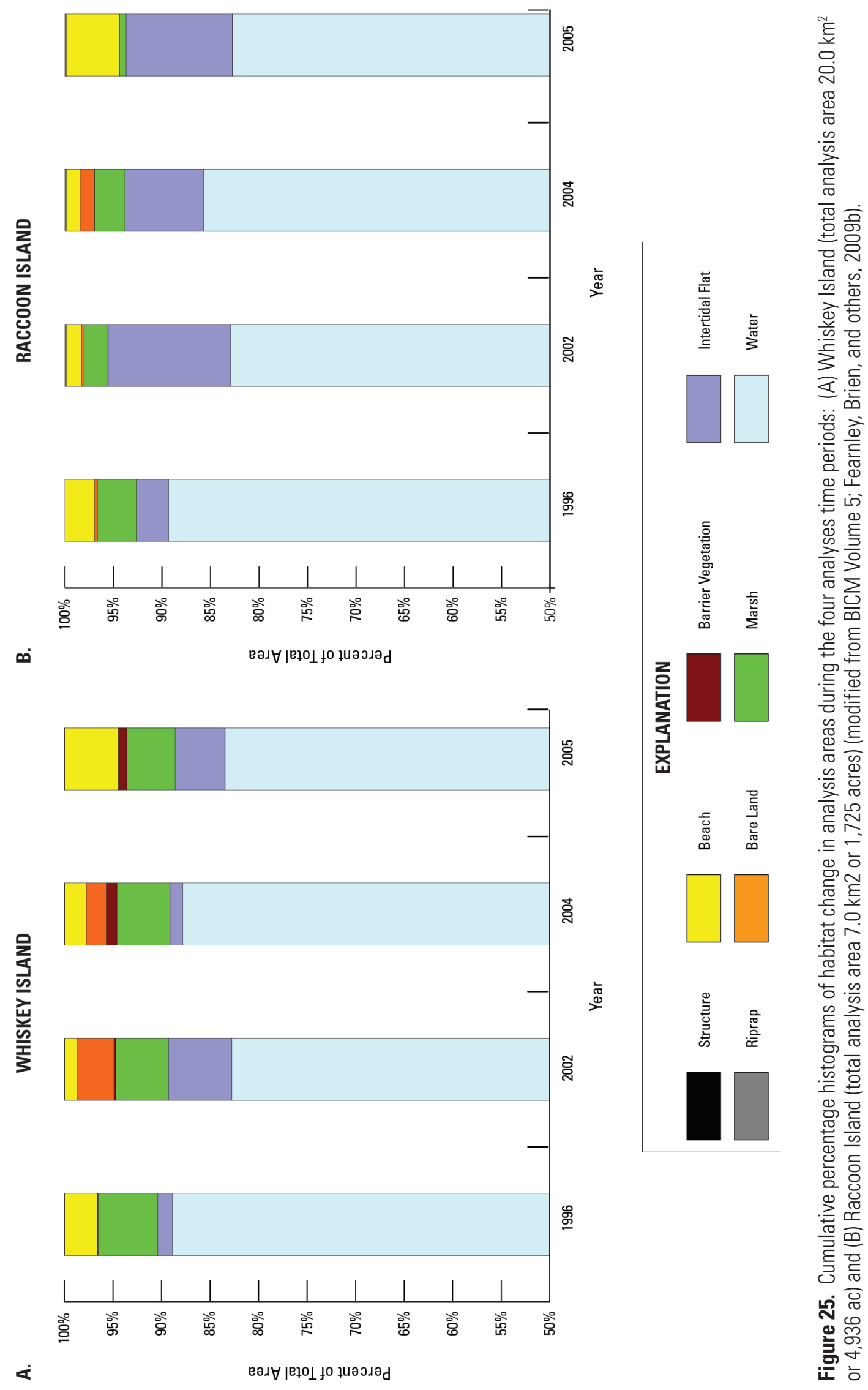

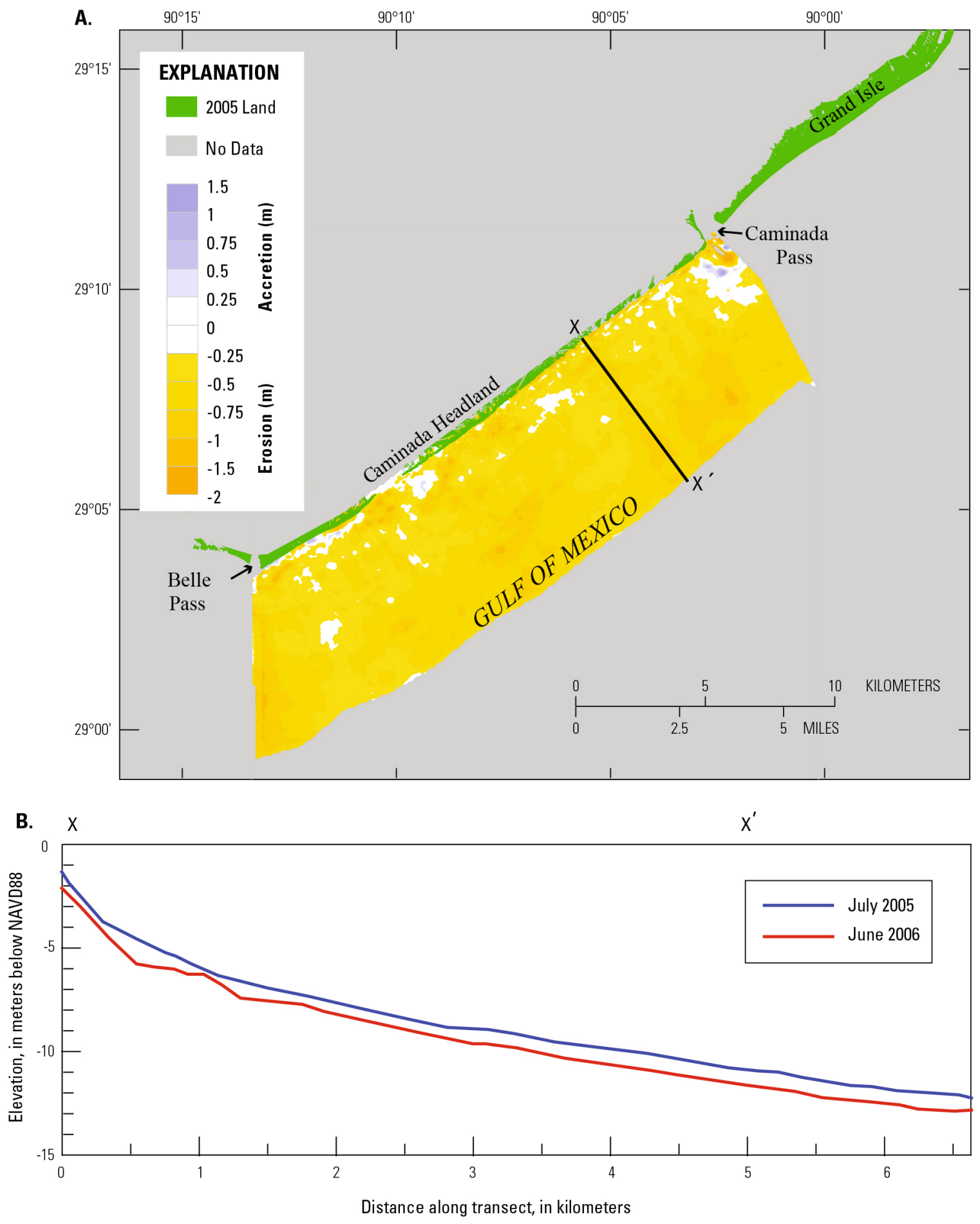

Figure 26. Caminada Headland shoreface seafloor-change map, 2005 to 2006: (A) Short-term bathymetric changes along the shoreface of the Caminada Headland and (B) the $x-x^{\prime}$ shore-normal profile comparison, demonstrating erosion that occurred between July 2005 and June 2006. The two surveys were separated by the 2005 hurricane season, during which Hurricanes Cindy, Katrina, and Rita impacted the study area. The volume of sediment eroded during this single year was almost 40 percent more than the long-term (1880s-2006) average of erosion. The map coordinate system is UTM Zone $15 \mathrm{~N}$ meters. Modified from Miner, Kulp, FitzGerald, Flocks, and Weathers, 2009, and DeWitt and others, 2007. Abbreviation: $\mathrm{m}$, meter. 

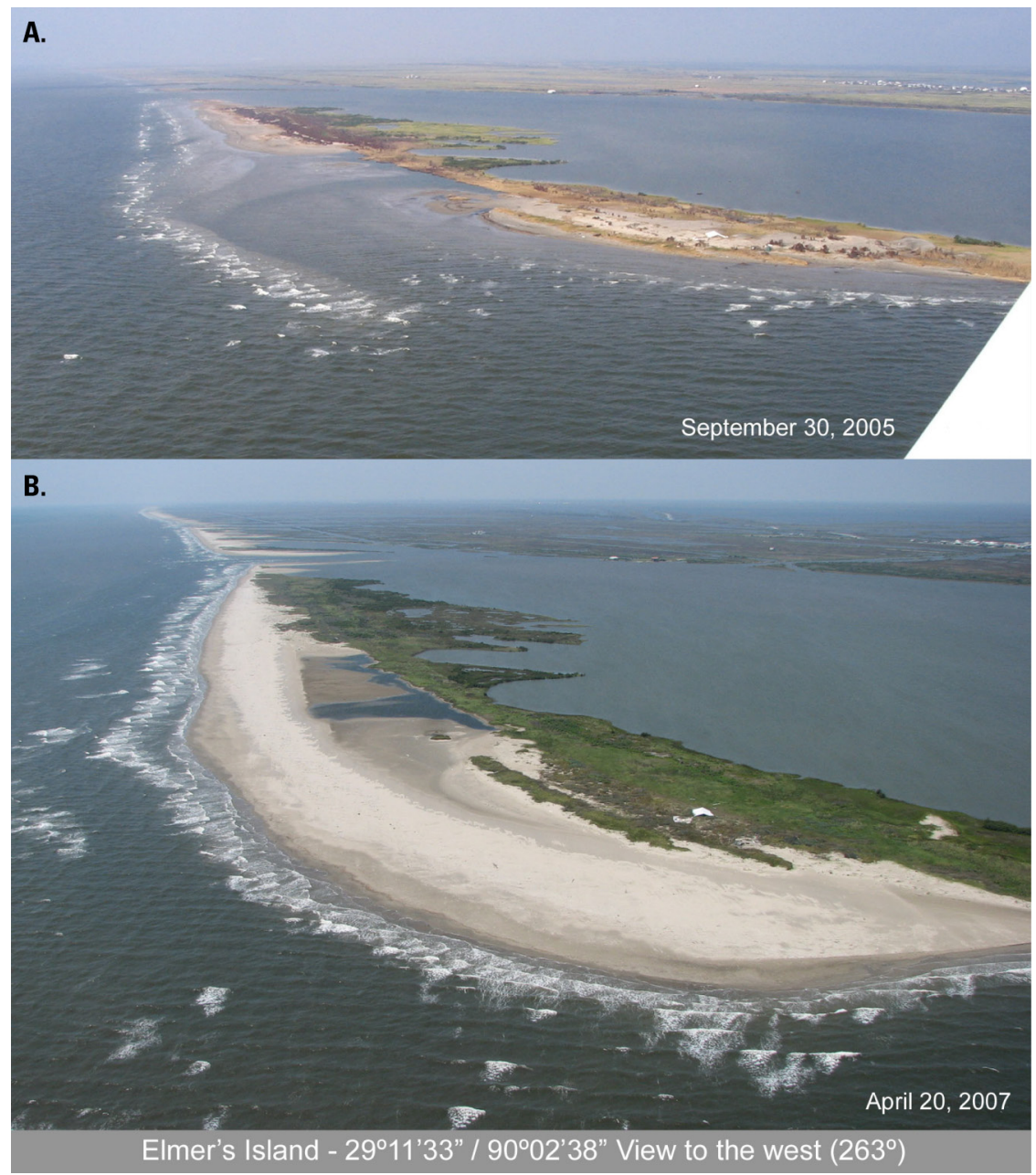

Figure 27. Example of Volume 1 Barrier-Shoreline Post-Storm Assessment aerial time-series photo pair of Elmers Island for 2005 and 2007 (BICM Volume 1; Westphal and Penland, 2009).

\section{Acadiana Bays}

The Acadiana Bays extend from Marsh Island to Point Au Fer Islands and include West Cote Blanche, East Cote Blanche, and Atchafalaya Bays (figs. 1 and 2). These shallow bays and marshes are remnants of the Teche/Maringouin inner-shelf delta complex and include some of the oldest deposits in the BICM study area. The Teche delta complex deposited sediments in this region from about 6,000 to 3,000 years ago, after which flow was directed eastward to the St. Bernard delta complex (Frazier, 1967). Presently, the predominant process is active deposition and delta building associated with the Atchafalaya River, which is generating some of the highest accretion rates (at the Wax Lake and Atchafalaya Deltas) in the Mississippi River Delta Plain. These sediments are mostly laminated muds with coarser-grained material accumulating proximal to the modern deltas.

Compared with the other BICM study areas, the Acadiana Bays region has historically been the focus of far fewer investigations; most of these studies focused on the Atchafalaya and Wax Lake Deltas. As reported by van Heerden and Roberts (1988), in the 1970s, subaerial growth of the bayhead Atchafalaya Delta resulted from sediment infilling of the Atchafalaya River Basin and flood events that delivered an increased sediment load from the basin to the river mouth in Atchafalaya Bay. Since then, flood events and human alterations have contributed to or reduced delta growth (Flocks and others, 2002). Van Heerden and Roberts (1988) described the delta stratigraphy as "old bay" fill and prodelta deposits that coarsen upward into distributary and levee deposits. Roberts and others (1997) described a similar geologic framework from the Wax Lake Delta. 
A stratigraphic cross section across Atchafalaya Bay to the west of the present navigation channel (fig. 28) shows the transition from a brackish-marsh environment into estuarine, or bay, and then modern fluvial delta (Flocks and others, 2002). Calibrated Accelerator Mass Spectrometry (AMS) radiocarbon-age dates from the marsh-peat layers range from 2,470 to 3,310 years BC, which corresponds to the end of active Teche Delta progradation. Averaged subsidence rate across the core transects is approximately $0.094 \mathrm{~cm} / \mathrm{yr}(0.037 \mathrm{in} / \mathrm{yr})$. This is the same average subsidence rate determined by Roberts and others (1994) from a core acquired approximately $19 \mathrm{~km}(12 \mathrm{mi})$ to the northwest (and within the second lobe of the Teche Delta, as defined by Frazier [1967]). Farther offshore, Neill and Allison (2005) measured deposition rates of Atchafalaya River muds at 1-2 cm/yr (0.4-1.79 in/yr). However, they suggested that sediment bypassing farther offshore and erosion by storms will prevent future land accretion in the area, constraining any subaerial extension to the modern Wax Lake and Atchafalaya Deltas.

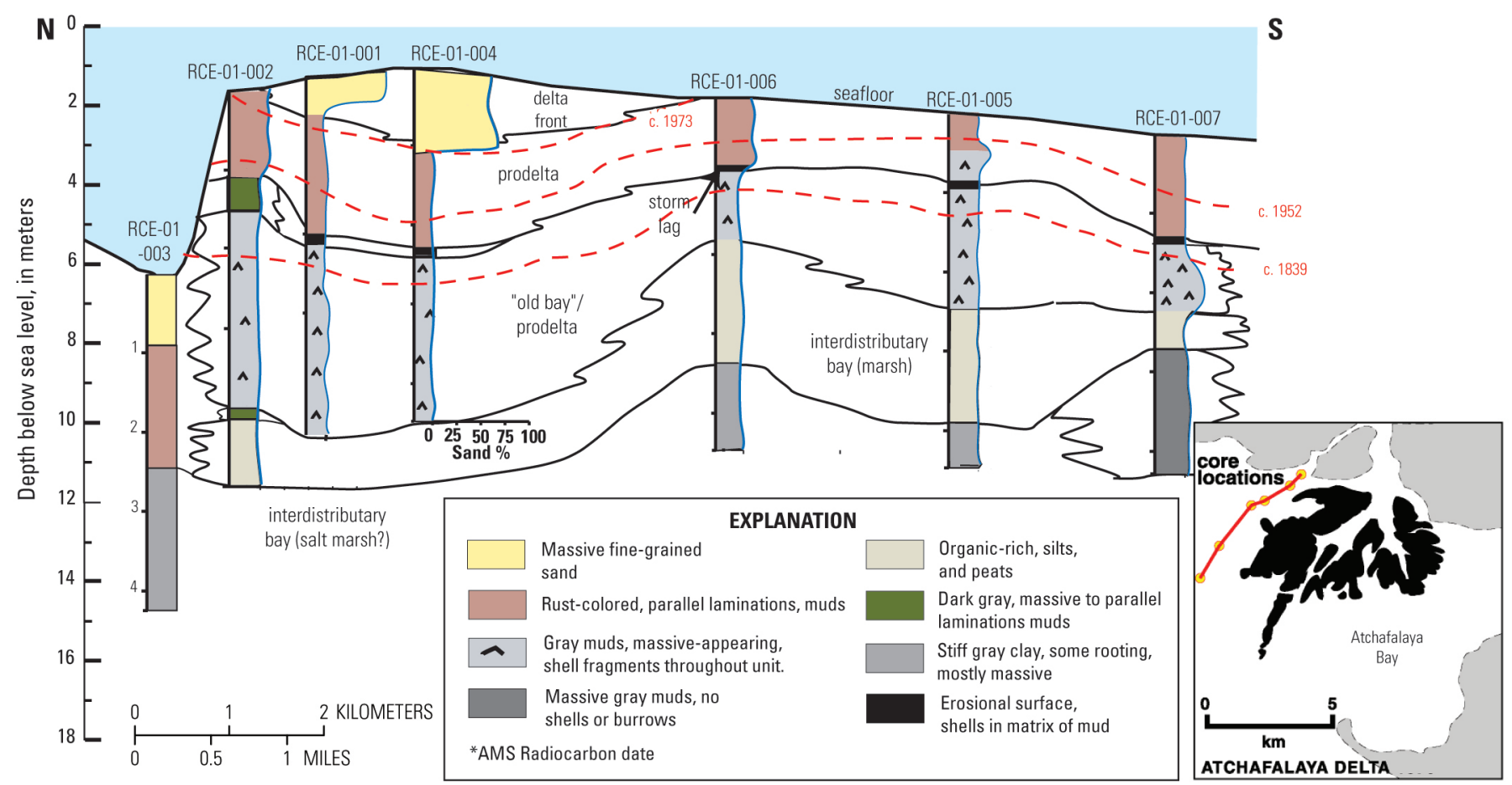

Figure 28. Vibracore transect across Atchafalaya Bay, to the west of the present navigation channel. The cross section reflects the transition from a brackish-marsh environment into estuarine, or bay, and then modern fluvial delta (modified from Flocks and others, 2002). Abbreviation: km, kilometer; AMS, Accelerator Mass Spectrometry.

\section{History of Topographic and Bathymetric Changes}

Shoreline-change trends in the Acadiana Bays region reflect the growth of the Atchafalaya and Wax Lake Deltas over the past century (fig. 29). In general, between the mid-1800s and the mid-1900s, rates of shoreline loss were fairly consistent, averaging about $-3.5 \mathrm{~m} / \mathrm{yr}(-11.5 \mathrm{ft} / \mathrm{yr}$ ) (calculated from Martinez, O'Brien, and others, 2009a). Over the next half century, the bay shoreline reaches continued to retreat even as rapid accretion at the Wax Lake and Atchafalaya Deltas was initiated. Since then, shoreline retreat across the bays has stabilized, and delta growth has continued. Despite delta growth of $>6 \mathrm{~m} / \mathrm{yr}(>20 \mathrm{ft} / \mathrm{yr}$ ) since the mid-1900s, long-term shoreline trends for the Acadiana Bays are negative, ranging from -1.5 to $-8.0 \mathrm{~m} / \mathrm{yr}$ ( -4.9 to $-26.3 \mathrm{ft} / \mathrm{yr})$, with a 119 -year cumulative average of $-3.0 \mathrm{~m} / \mathrm{yr}(-9.8 \mathrm{ft} / \mathrm{yr})$, and an average cumulative retreat of $1.2 \mathrm{~km}(0.75 \mathrm{mi})$. No bathymetric data were collected in the Acadiana Bay region during the BICM project. 


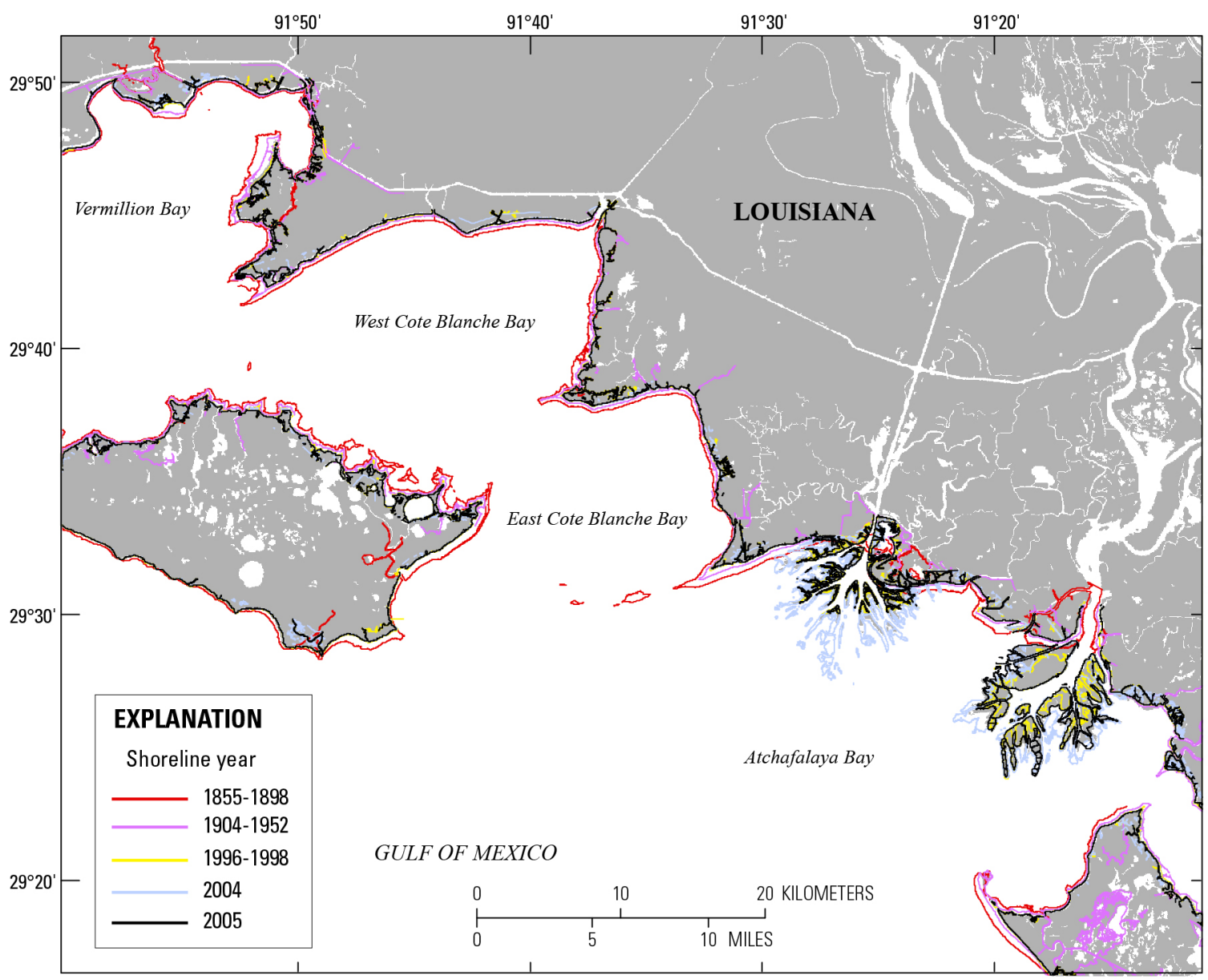

Figure 29. Shoreline-change map (1800s to 2005) of the Morgan City quadrangle. USGS Quadrangle in the Acadiana Bays region analyzed during BICM project (BICM Volume 2; Martinez, O'Brien, and others, 2009a).

A.

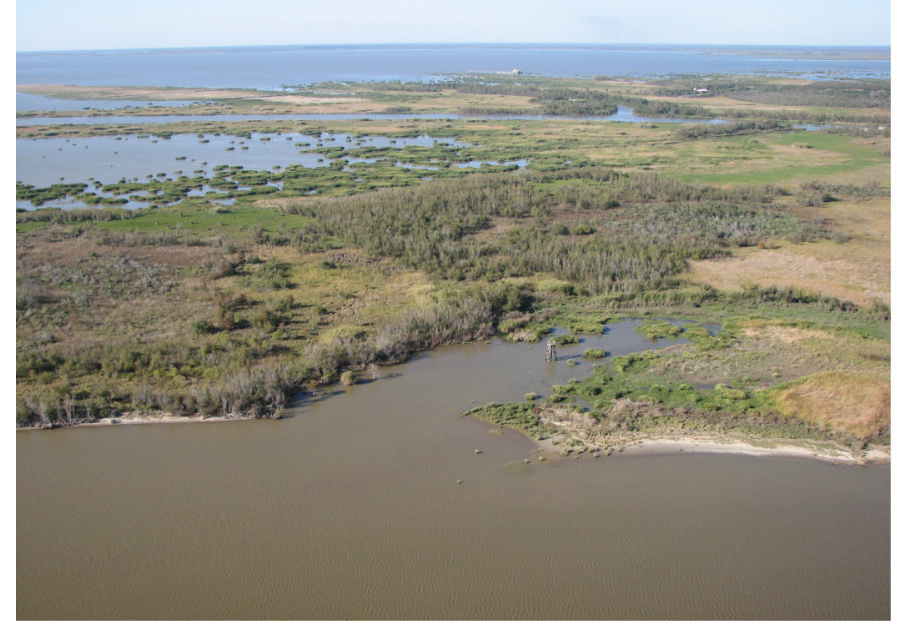

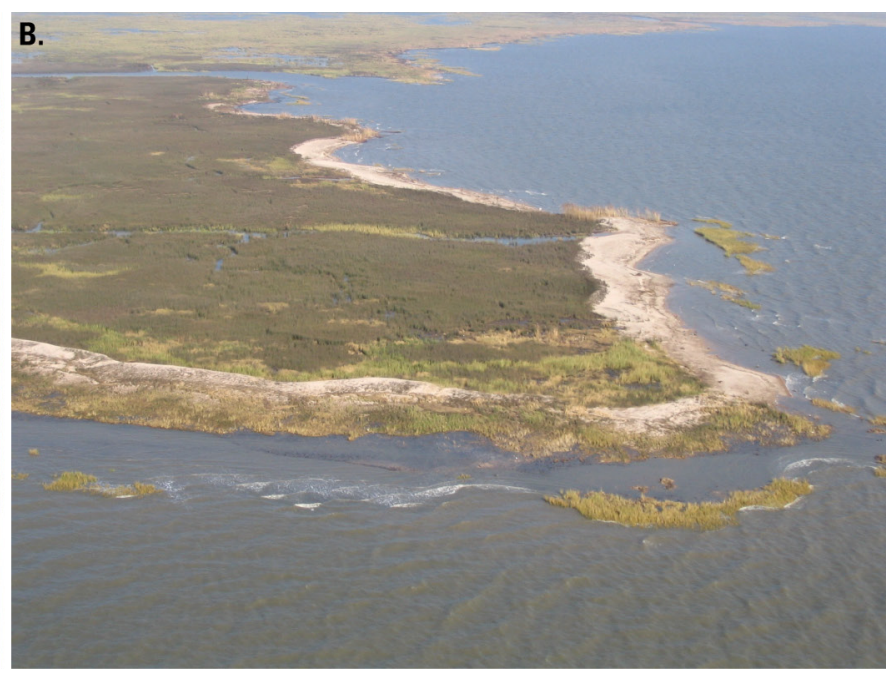

B.

Figure 30. Oblique aerial photos: (A) Atchafalya Delta, 2006, and (B) Marsh Island, 2005, shorelines taken as part of the BICM program (BICM Volume 1; Westphal and Penland, 2009). 


\section{Habitat Changes and Impacts of Storms}

No habitat classification or change data were collected in the Acadiana Bays region during the BICM project. This is an important data gap in the BICM program. In 2005, post-Hurricanes Katrina and Rita photography was acquired as a photo survey of the Marsh Island Gulf shoreline (fig. 30). This photo survey was integrated into the BICM Volume 1 dataset, but no further analysis, historical time-series photography, or post-hurricane photo pairs are available. This is an important data gap in the BICM program.

\section{Chenier Plain}

The Chenier Plain extends from Sabine Pass in the west to Southwest Point on Vermillion Bay in the east. The BICM project further divided the Chenier Plain into the western and eastern Chenier Plain (Sabine Pass to the Lower Mud Lake Outlet and Lower Mud Lake Outlet to Southwest Point, respectively) (figs. 1 and 2). The Sabine, Calcasieu, and Mermentau Rivers transect the Chenier Plain. Four major lakes in the Chenier Plain (Sabine and Calcasieu Lakes in the western Chenier Plain and Grand and White Lakes in the eastern Chenier Plain) formed as bays at the mouths of drowned late Pleistocene incised river valleys as sea level rose during the Holocene. Early studies (Fisk, 1944; Byrne and others, 1959; Gould and McFarlan, 1959) correlated the timing and development of individual ridges and chenier complexes with delta-lobe switching and shifts in the location of the Delta Plain depocenters. Penland and Suter (1989) and McBride and others (2007) further refined these chronologies and described in detail the distribution, geomorphic features, and processes that formed the different cheniers and chenier complexes. Although transgressive processes dominated along the Chenier Plain coastline historically, with the modern Mississippi deltaic depocenter located in the eastern delta plain, Huh and others (2001) and Draut and others (2005) documented renewed mudflat progradation and increased sediment deposition on the inner-continental shelf along the eastern Chenier Plain coastline associated with sediment derived from the Atchafalaya River.

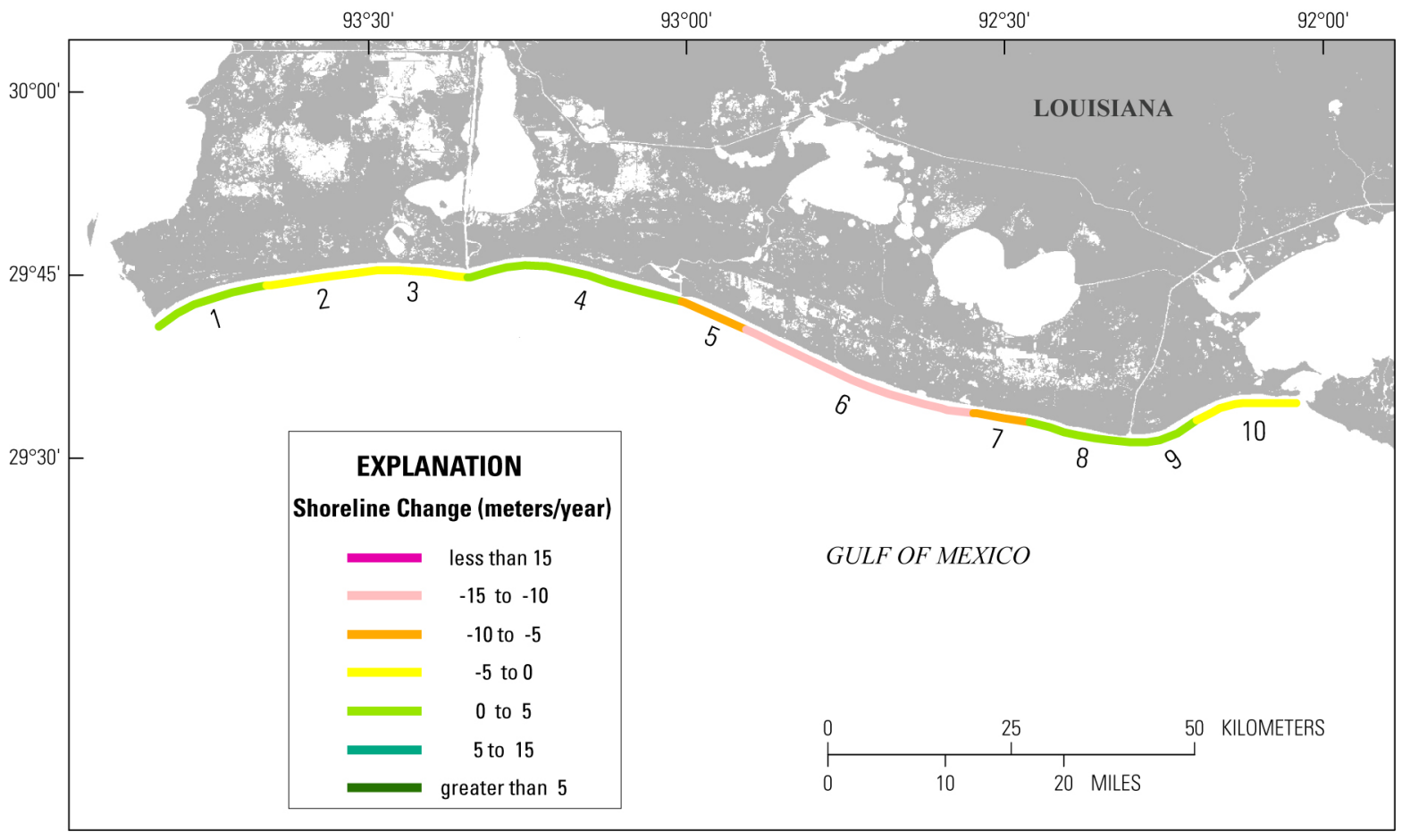

Figure 31. Historical (1855 to 2005) shoreline-change rates in meters per year along the Chenier Plain coastline (BICM Volume 2; Martinez, O'Brien, and others, 2009a). 


\section{History of Topographic and Bathymetric Changes}

BICM and historical bathymetric data were collected only offshore of the western Chenier Plain beaches, whereas lidar surveys and shoreline-change analyses were conducted along the entire length of the Chenier Plain coastline. Historically, the western Chenier Plain shoreline has been relatively stable, with average shoreline-change rates averaging $0.73,-4.49$, and $0.7 \mathrm{~m} / \mathrm{yr}(2.4,-1.6$, and $2.3 \mathrm{ft} / \mathrm{yr})$ for the historical (1855-2005), long-term (1904-2005), and shortterm (1996-2005) periods, respectively (Martinez and others, 2009a). In contrast, the eastern Chenier Plain shorelines experienced rapid retreat of $-4.1,-4.76$, and $-7.3 \mathrm{~m} / \mathrm{yr}(-13.4,-15.6$, and $-23.8 \mathrm{ft} / \mathrm{yr})$ during the same time periods (fig. 31; Martinez, O’Brien, and others, 2009a). In particular, the Mermentau River, Rockefeller Refuge, and Mulberry Island shoreline reaches consistently experienced very high rates of erosion (up to $-15.6 \mathrm{~m} / \mathrm{yr}$ or $-51.0 \mathrm{ft} / \mathrm{yr}$ short-term change along the Rockefeller Refuge shoreline). The Freshwater Bayou shoreline is the only reach in the eastern Chenier Plain where the shoreline prograded (2.6 to $3.2 \mathrm{~m} / \mathrm{yr}$ or 8.6 to $10.4 \mathrm{ft} / \mathrm{yr}$ ) for the historical to short-term analysis periods. This shoreline corresponds to the same area where Huh and others (2001) and Draut and others (2005) documented mudflat progradation and inner-shelf deposition along the eastern Chenier Plain coast. Average near-term shoreline-change rates differed significantly from the historical- to decadal-scale change rates for both the western $(18.2 \mathrm{~m} / \mathrm{yr}$ or $60.0 \mathrm{ft} /$ yr) and eastern $(0.76 \mathrm{~m} / \mathrm{yr}$ or $2.5 \mathrm{ft} / \mathrm{yr})$ Chenier Plain coastlines. Assuming that these changes are indicative of nearly instantaneous redistribution of sediment from the nearshore area by Hurricane Rita, it is unlikely that the near-term trends will persist into the future.

Bathymetric data collected for BICM in 2007 (fig. 32) were compared with historical survey data from the 1880s and 1920s to create bathymetric-change maps and calculate volumes of sediment erosion and deposition along the western Chenier Plain beaches over the past $\sim 130$ years (Miner, Kulp, Weathers, and Flocks, 2009). These maps show significant changes in depositional patterns for the 1880 s to 1920 s relative to the 1920 s to $2007 \mathrm{~s}$ time period (figs. 33 and 34 ). The 2007 dataset also serves as a baseline (post-Hurricane Rita) for future change analyses. Between the 1880s and 1920s, significant volumes of sediment were deposited in the Calcasieu Pass and Sabine Pass ebb-tidal deltas (net deposition $55.4 \times 10^{6}$ and $56.8 \times 10^{6} \mathrm{~m}^{3}$ or $72.5 \times 10^{6}$ and $74.3 \times 10^{6} \mathrm{yd}^{3}$, respectively), and the overall trend for the nearshore areas was essentially no change or sediment deposition (fig. 33). The only areas that showed net sediment erosion during this time were the Calcasieu River inlet and the nearshore extent along the Lower Mud Lake shoreline. In contrast, except for Calcasieu River ebb-tidal delta and localized deposition updrift of the Sabine and Calcasieu Pass jetties, most of the

\section{Western Chenier Beaches 2007 Bathymetry}

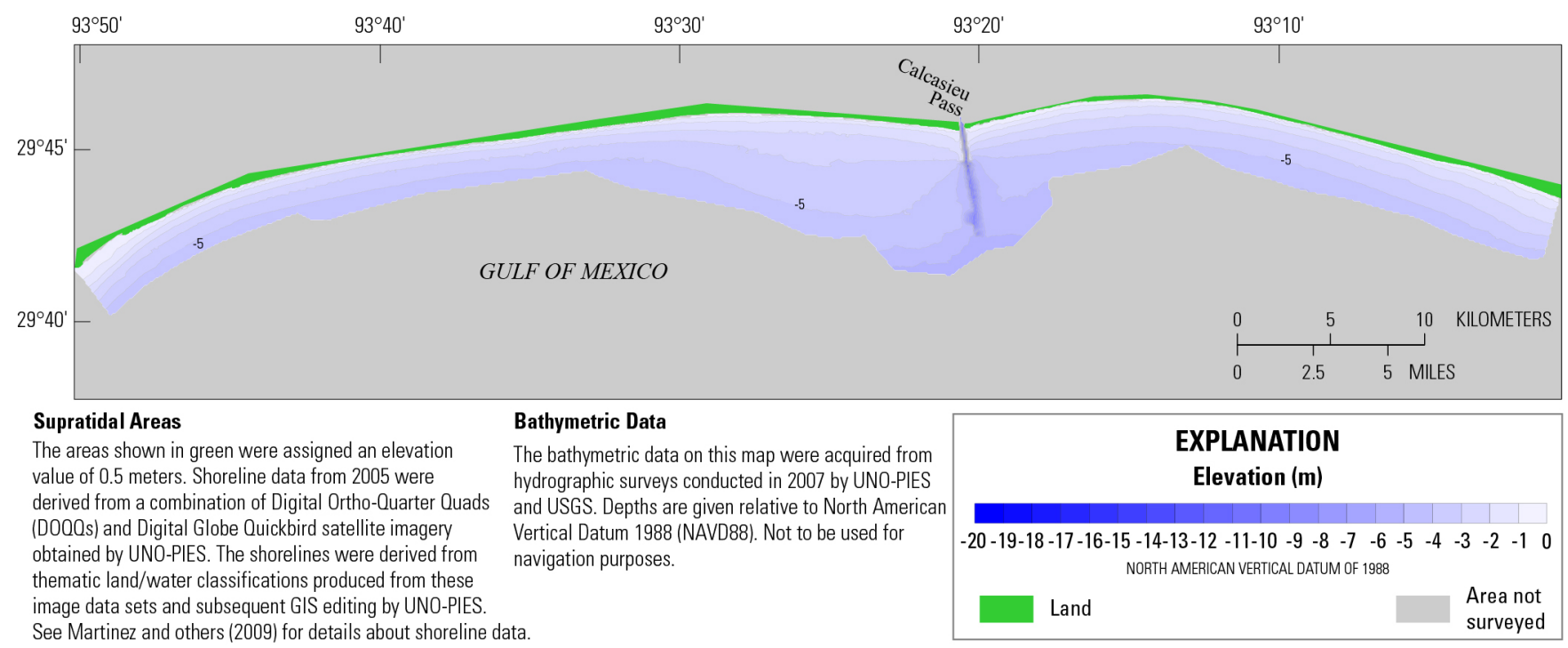

Figure 32. Western Chenier shoreline and 2007 bathymetric map using BICM-program data. Land is indicated by green with shorelines derived from thematic classifications produced from image datasets and GIS editing (BICM Volume 3; from Miner, Kulp, Weathers, and Flocks, 2009). Abbreviation: m, meter. 


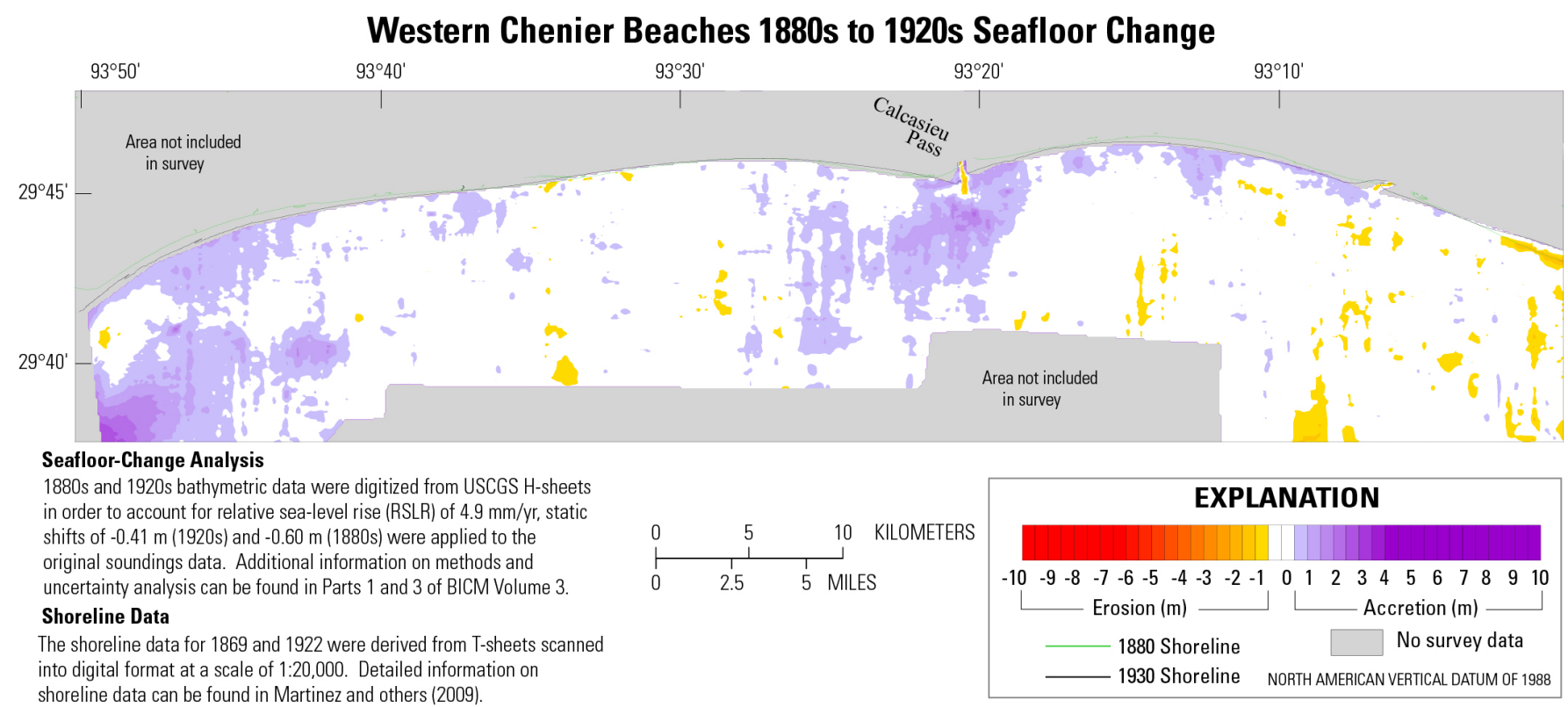

Figure 33. Western Chenier historical seafloor-change map from the 1880s to 1920s using digitized H-and T-sheets from the US Coastal and Geodetic Survey (modified from BICM Volume 2; Martinez, O'Brien, and others, 2009a) and seafloor change methods and uncertainty analysis (BICM Volume 3; Miner, Kulp, Weathers, and Flocks, 2009). Abbreviation: m, meter.

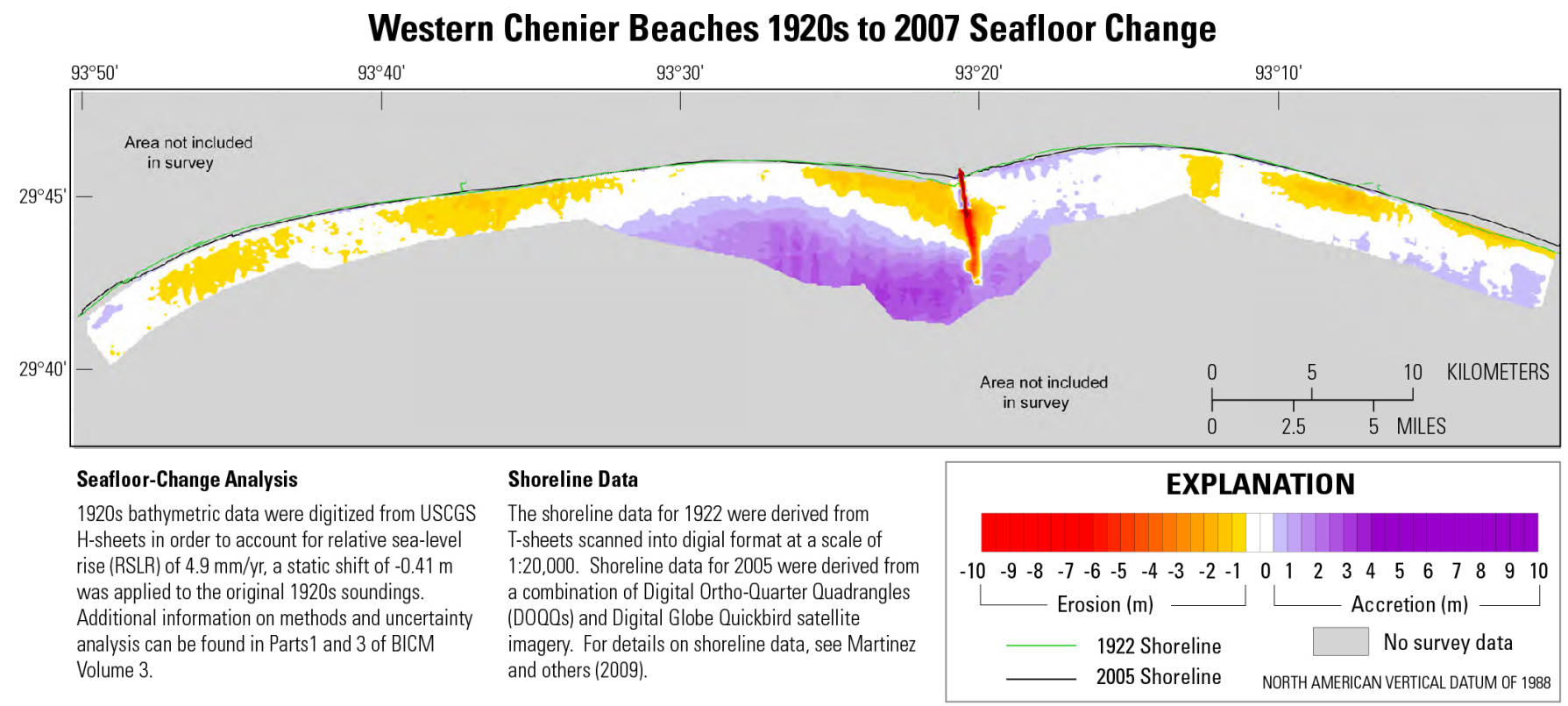

Figure 34. Western Chenier historical seafloor-change map from the 1920s to 2007 using digitized H- and T-sheets from the U.S. Coast and Geodetic Survey (modified from BICM Volume 2; Martinez, O'Brien, and others, 2009a) and seafloor change methods and uncertainty analysis (BICM Volume 3; Miner, Kulp, Weathers, and Flocks, 2009). Abbreviation: m, meter. 
analysis areas along the western Chenier Plain coastline underwent seafloor erosion between the 1920s and 2007 (fig. 34). However, because of the large volume of sediment deposited in the Calcasieu River ebb-tidal delta offshore from Calcasieu Pass (net sediment deposition $130.8 \times 10^{6} \mathrm{~m}^{3} ; 171.1 \times 10^{6} \mathrm{yd}^{3}$ ), the overall 1920s to 2007 change for the entire analysis extent was net sediment accumulation. The change in historical depositional patterns was likely due in large part to dredging and enlargement of the deep-draft Calcasieu Ship Channel, which channeled freshwater flow and sediment discharge to the Gulf of Mexico, bypassing the interior coastal wetlands and the nearshore coastal areas (LCWCRTF, 2002e; McCorquodale and others, 2009; Meselhe and Miller, 2009).

\section{Habitat Change}

BICM habitat classification and change analyses were limited to the western Chenier Plain beaches; no habitat data were collected in the eastern Chenier Plain. Total marsh habitat in the western Chenier Plain remained relatively constant from 1998 to 2005, although there was some variability within the separate analysis areas. Construction of the Holly Beach Sand Management Project (CS-31) was completed in 2003. This CS-31 project restored approximately 300 acres of beach habitat between Holly and Constance Beaches, reestablished the shoreline near its historical position, and protected approximately 8,000 acres of existing intermediate and brackish-marsh wetlands north of the beach (LCWCRTF, 2004). The positive benefit of this project is reflected in the increased beach and marsh acreage in this area between 2001 and 2004. The amount of intertidal flat present in 2001 is significantly less than that in 1998 or 2004 because of the high water at the time that the 2001 imagery was acquired. Scouring and flooding of low-lying areas near the coastline after the passage of Hurricane Rita resulted in lower acreages of marsh habitat in 2005 compared with that in earlier years (fig. 35).

BICM Habitat Change Analysis: Holly Beach, West Chenier Plain Habitat Change Classification - 2005 from 2004

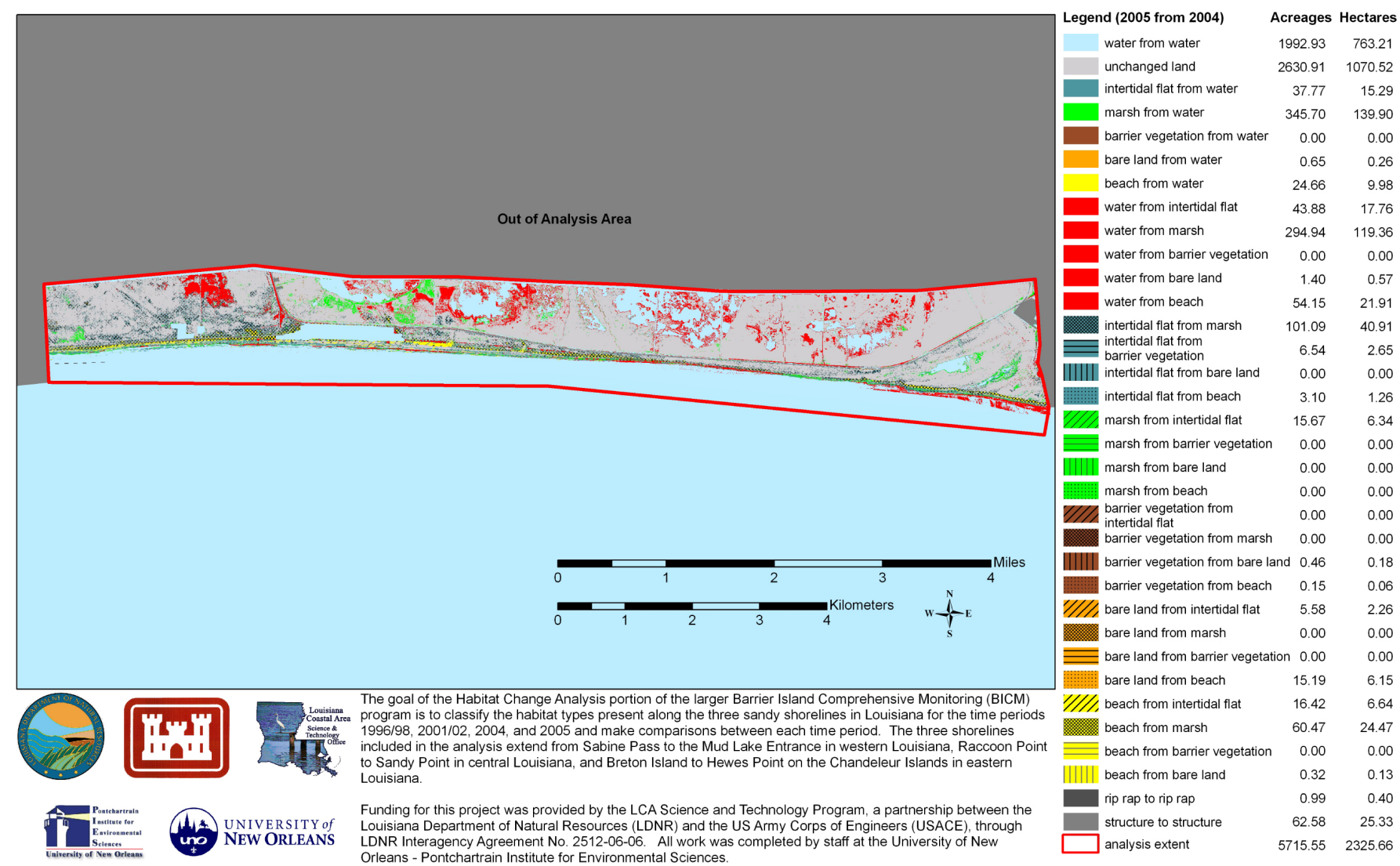

Figure 35. BICM habitat-change map (1998 to 2002) for Holly Beach along the western Chenier Plain. This is a final product of data collected during the BICM project used first to classify habitats and then to determine change in habitats over time along the Louisiana coast (BICM Volume 5; Fearnley and others, 2009b). 
Similarly, beach habitat was reduced in most areas in 2005; however, some localized increases in beach habitat were observed. These increases were the result of sediment being redistributed inland with the storm surge.

\section{Impacts of Storms}

The Chenier Plain was significantly impacted by Hurricane Rita, which made landfall on September 24, 2005, west of Johnson's Bayou in southwestern Louisiana. Post-hurricane photo pairs from 2005 and 2006 and historical timeseries photos compiled for the BICM Volume 1 post-storm assessment documented significant damage along the Chenier Plain coastline as far east as Freshwater Bayou in the eastern Chenier Plain. In many locations, large volumes of sand were deposited inland of the previously existing beach, and extensive areas of low-lying coastal wetlands were flooded by the storm surge (fig. 36).

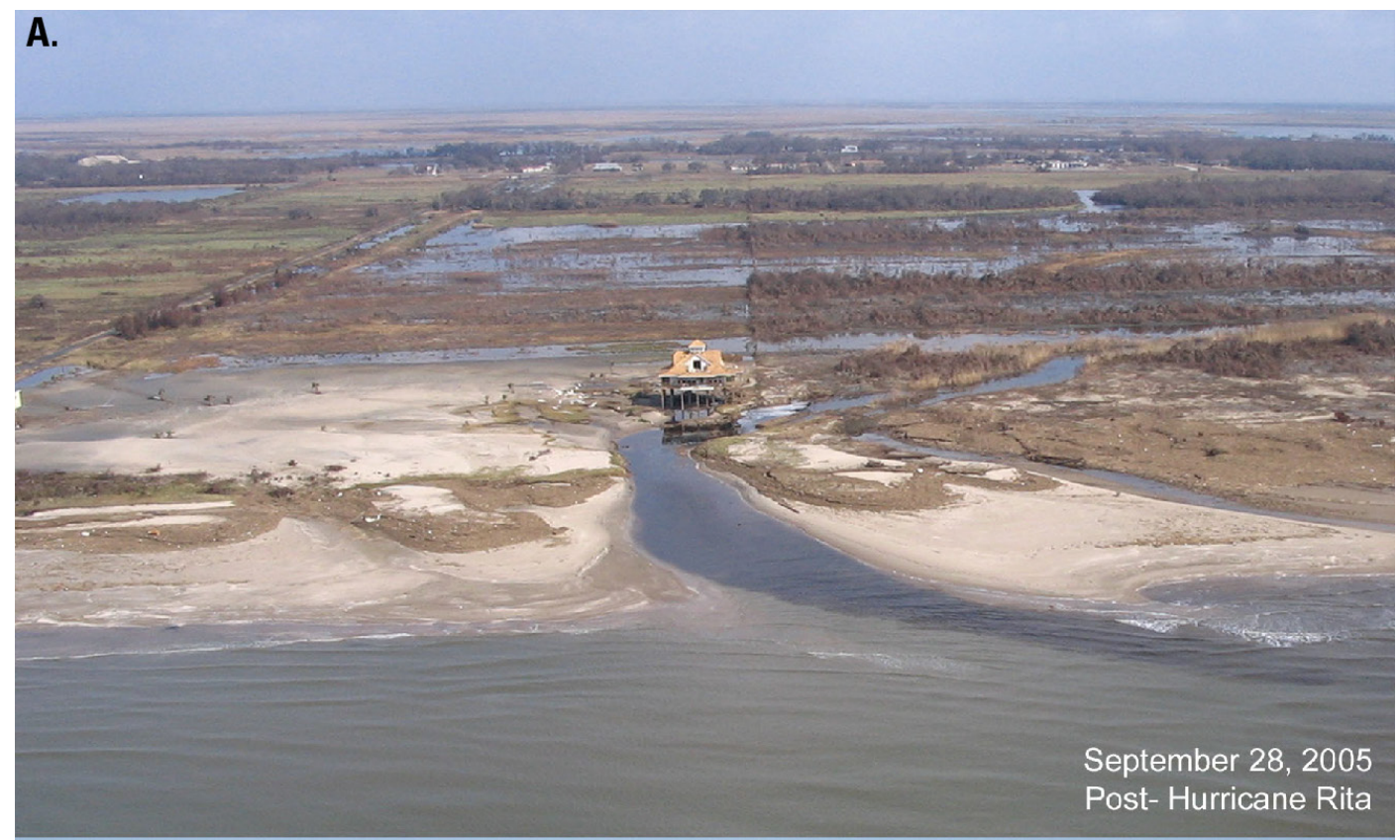

B.

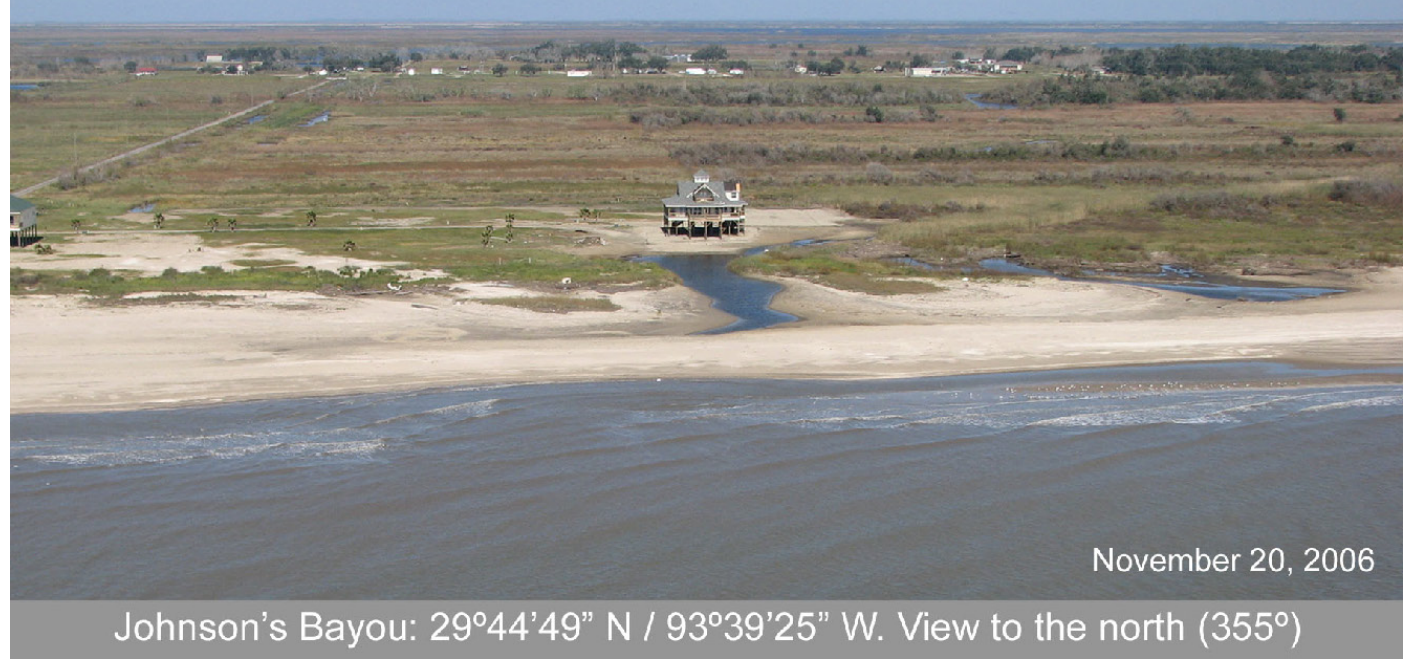

Figure 36. Oblique aerial time-series photo pair of Johnson's Bayou shoreline for the years 2005 and 2006 (BICM Volume 1, Westphal, 2008). House is in the same location. 


\section{Discussion of Louisiana Coast-Wide and Topical Themes}

Data collected during the BICM program were extensive and make up one of the broadest available coastal geophysical datasets for the Gulf of Mexico (GOM). In an attempt to integrate the data collected into meaningful analyses of the Louisiana shoreline, several coastal-wide and topical themes have been selected. The objectives of the thematic discussions are to address coast-wide impacts of relative sea-level change to the Louisiana coastal system, focusing on inlets, extreme storms, and habitats.

\section{THEME 1: Barrier-Shoreline Evolution in a Regime of Rapid Relative Sea-Level Rise and Interior-Wetland Loss}

Rates of RSLR, which are locally in excess of $1 \mathrm{~cm} / \mathrm{yr}(0.39 \mathrm{in} / \mathrm{yr})$, are driving barrier-shoreface retreat along the periphery of the Mississippi River Delta Plain. In addition, historical wetland losses in the delta-plain interior totaled more than 2,300 $\mathrm{km}^{2}\left(888 \mathrm{mi}^{2}\right)$ between 1956 and 2004 (fig. 37). This conversion of interior wetlands to open water increased bay tidal prisms, resulting in degradation of barriers through inlet widening, development of new inlets, and sediment storage in ebb-tidal deltas.

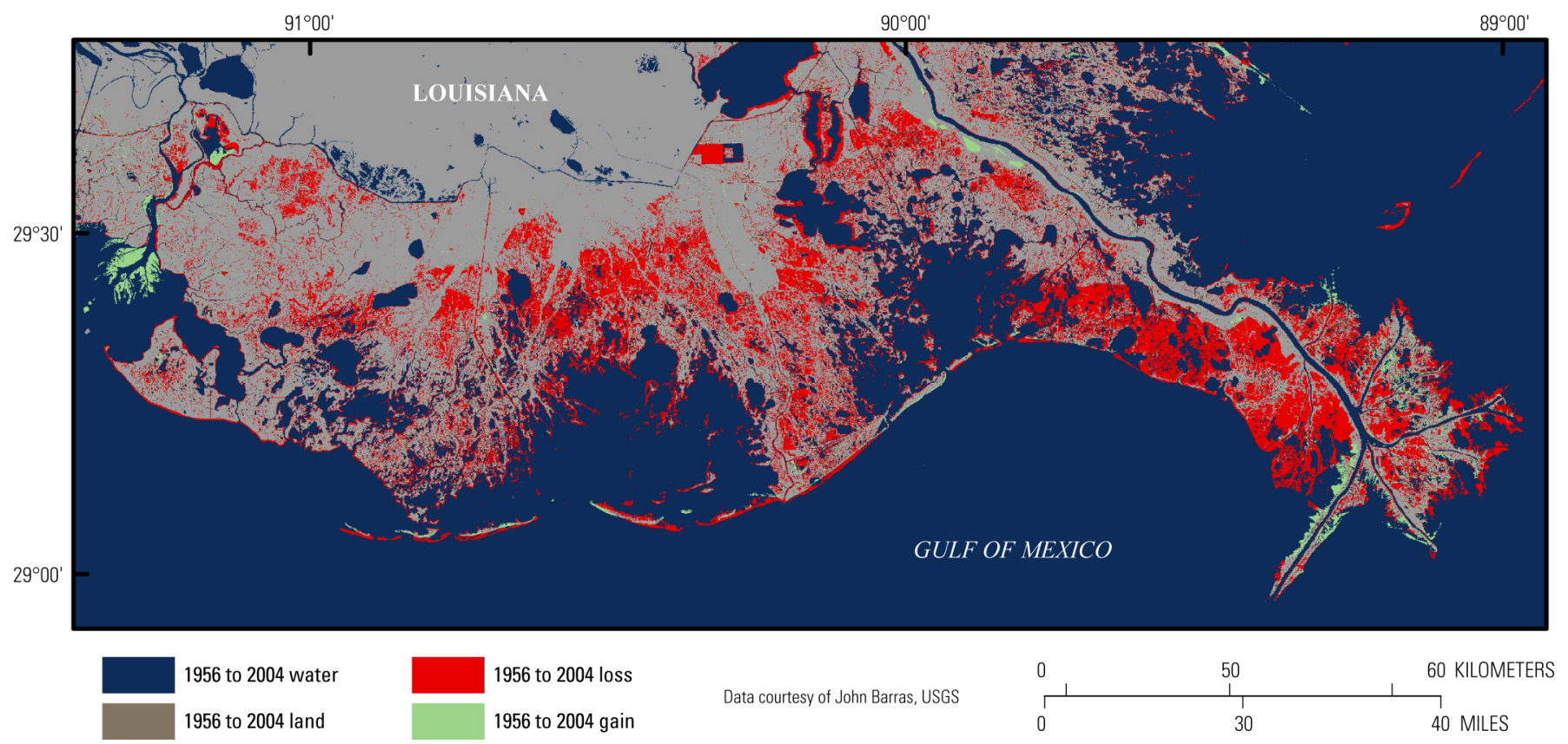

Figure 37. Southern coastal Louisiana land-loss change analysis, 1956 to 2004 (red is conversion of marsh to open water, and green is conversion of open water to marsh or delta). Data from Barras and others (2008) and Morton and others (2010).

Bathymetric surveys completed as part of the BICM effort combined with historical bathymetry from three earlier time periods (dating to the 1880s) provide a series of digital-elevation models (DEMs) from Raccoon Point in Terrebonne Parish to Sandy Point in Plaquemines Parish (fig. 22). These models capture the three-dimensional morphological evolution of this area. As outlined in Miner, Kulp, Penland, and others (2009), these datasets identified three dominant trends during the 125-year period: (1) erosion of $\sim 1.6 \times 10^{9} \mathrm{~m}^{3}\left(\sim 2.1 \times 10^{9} \mathrm{yd}^{3}\right)$ from the shoreface, forcing shoreface retreat, (2) deposition in coastal bights and at ebb-tidal deltas, and (3) an increase in collective tidal-inlet cross-sectional area from $\sim 41,400 \mathrm{~m}^{2}$ to $\sim 139,500 \mathrm{~m}^{2}\left(\sim 445,625\right.$ to $\sim 1,501,565$ square feet [ $\left.\mathrm{ft}^{2}\right]$ ) (refer to the Modern Delta, Lafourche, 
and Teche Deltas, Regional Discussions section in this report for more detail). The rate of increased tidal-inlet crosssectional area is directly proportional to the rate of interior-wetland loss. By comparing data collected between short time frames (years to decades) to long-term trends, Miner, Kulp, Penland, and others (2009) reported that rates of shoreface erosion and landward barrier migration are significantly greater from storm impacts when compared to the long-term trends. Historical shoreline-change analysis also shows that rates of as much as $3 \mathrm{~km} /$ century of barrier-shoreline retreat during the past 125 years are accompanied by erosion of the back-barrier shorelines, indicating that a net loss of sediment from the system coupled with rapid RSLR is causing the barriers to drown in place.

\section{Physical Coastal Processes}

The wave climate affecting the Louisiana coast can be divided into offshore- and nearshore-waves regimes, the latter generated by cold fronts and tropical storms. Deep-water wave data compiled from buoy records over the past 3 decades provide a mean wave-height range of 0.3 to $1.3 \mathrm{~m}(0.98$ to $4.27 \mathrm{ft})$ (Georgiou and others, 2005). Closer to shore, wind direction is generally from the south and southwest during the summer, and from the northeast and south during the winter. Nearshore-wave climate ranges from 0.07 to $0.8 \mathrm{~m}(0.23$ to $2.63 \mathrm{ft})$, with the higher-wave climate dominated by weak storms. Tropical storms, however, can generate wave heights up to $2 \mathrm{~m}(6.56 \mathrm{ft})$. The most drastic shoreline change has been observed following the passage of tropical storms, although the much higher frequency of cold-front passage makes them an important component in nearshore sediment-transport processes (Georgiou and others, 2005).

Relative sea-level rise in coastal Louisiana is driven by subsidence and eustatic sea-level rise. Subsidence rates in Louisiana are 3 to 4 times higher than average rates in the Gulf of Mexico (Penland and Ramsey, 1990). Although subsidence is dominated by compaction of the recently deposited Mississippi River Delta Plain stratigraphy, faulting and fluid extraction also contribute locally, along with glacial isostatic adjustment and lithospheric flexure (Yu and others, 2012). Data acquired from the NOAA tide gage at Grand Isle show a long-term (1947-2006) rate of $0.92 \mathrm{~cm} / \mathrm{yr}(0.36 \mathrm{in} /$ yr), although the rate appears to be slowing in recent years (Miner, Kulp, Penland, and others, 2009). Morton and Bernier (2010) suggest a slowing trend in subsidence rates may be the result of rebalancing of subsurface stresses following the reduction of fluid withdrawal, a trend that may be reflected in the short-term RSLR rate. Natural RSLR and the conversion of wetlands to open water are further exacerbated by anthropogenic alterations. Constraining the Mississippi River with engineered levees reduces the amount of river-borne sediments contributing to land building, and the excavation of access canals for oil and gas extraction increases wave activity, salinity, and tidal volume, resulting in further erosion of the wetlands (FitzGerald and others, 2004; Miner and others, 2007).

\section{Coastal-Sediment Budget}

Results of the BICM bathymetric data compared to historical data (1880s to 2006) show that over the past 125 years, $1.6 \times 10^{9} \mathrm{~m}^{3}\left(2.1 \times 10^{9} \mathrm{yd}^{3}\right)$ of sediment have been removed from the coastal system along the Teche, Lafourche, and Modern Delta shoreline (Miner, Kulp, Motti, and others, 2009). Erosion has not been spatially consistent in this system, with the majority volume per unit area occurring along the Caminada Headland $\left(-3.4 \mathrm{~m}^{3} / \mathrm{m}^{2},-4.5 \mathrm{yd}^{3} / \mathrm{yd}^{2}\right)$ and Isle Dernieres areas $\left(-2.1 \mathrm{~m}^{3} / \mathrm{m}^{2},-2.75 \mathrm{yd}^{3} / \mathrm{yd}^{2}\right)$, mainly from within the lower shoreface (Miner, Kulp, Penland, and others, 2009).

As the shoreface erodes and retreats, the tidal inlets separating the barrier islands migrate landward, hydraulically scouring the seafloor as they advance while infilling and shoaling at their seaward extent. At the same time, interiorwetland loss is occurring at extremely high rates. Between 1956 and 2004, more than 1,600 $\mathrm{km}^{2}\left(618 \mathrm{mi}^{2}\right)$ of wetlands within the Barataria and Terrebonne Basins have been converted to open water (Barras, 2006). As the tidal prism increases, so does flow at the inlets, creating more scour at the inlet throat and more efficient sediment trapping at the ebbtide deltas (FitzGerald and others, 2004, 2007; Miner and others, 2007). The enhanced sediment sink seaward of the inlets sequesters material offshore, removing it from the barrier-island system. Over the 125-year study period, more than $80 \mathrm{x}$ $10^{6} \mathrm{~m}^{3}\left(105 \times 10^{6} \mathrm{yd}^{3}\right)$ of sediment have accumulated offshore from Barataria Pass and adjacent inlets, while $5 \times 10^{6} \mathrm{~m}^{3}$ have been removed from the adjacent Grand Isle inner shelf over the same time period (Miner, Kulp, Penland, and others, 2009). 


\section{THEME 2: Hurricane Impact to the Chandeleur Islands during the Period 1855 to 2005 and the Likelihood of Island Recovery}

The impact of hurricanes on coastal systems has been intensively studied, but only recently have quantitative analyses progressed to strengthen realistic predictive modeling of the impact and likelihood of barrier island recovery following a hurricane. Developing these predictive capabilities requires baseline data and repetitive pre- and post-storm data. The BICM program has progressively provided baseline data for much of the Louisiana coast, but repetitive pre- and post-storm data are lacking in many areas. The Chandeleur Islands have been extensively studied using the comprehensive database collected by BICM along with pre- and post-storm data from Hurricanes Katrina and Rita and several minor storm events. The results from these studies provide a basis for understanding the impact of storms events along other sections of the Louisiana coast. Therefore, the recovery of the Chandeleur Islands as a proxy for coastal Louisiana is described until sufficient pre- and post-storm data are available to develop predictive models for other Louisiana barrier islands and shorelines.

The Chandeleur Islands is an arcuate barrier-island chain, extending $80 \mathrm{~km}(49 \mathrm{mi})$ that extends from Hewes Point north of the Chandeleur Islands, along the ephemeral shoals of Curlew and Grand Gosier Islands, to Breton Island in the south (fig. 38). Similar to other barrier islands of the northern GOM, the Chandeleur Islands are important

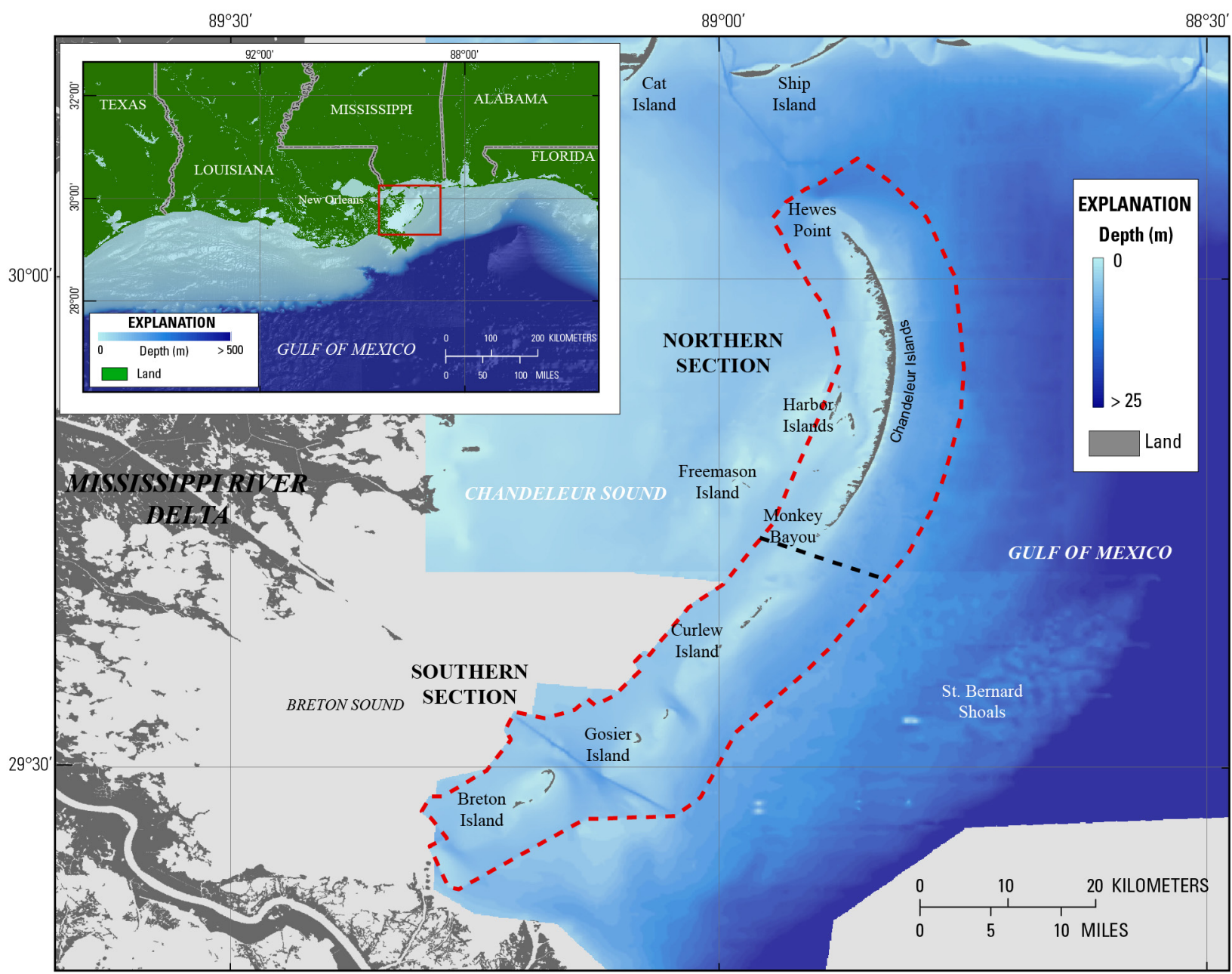

Figure 38. Location map showing the Chandeleur Islands relative to other physiographic features. The Chandeleur Islands shoreline shown is from 2002. The inset bathymetry is from the Coastal Relief Model (Divins and Metzger, 2008). The bathymetry in the larger map is a composite of bathymetry collected during the BICM program and the Coastal Relief Model. Abbreviation: m, meter. 
because they (1) attenuate storm impacts for mainland Louisiana and Mississippi (Stone and Orford, 2004; Stone and others, 2005), (2) regulate estuarine salinity and circulation (Reyes and others, 2005), and (3) provide unique habitat for threatened and endangered species (Poirrier and Handley, 2007; Fearnley, Miner, Kulp, Bohling, Martinez, and Penland, 2009; Fearnley, Miner, Kulp, Bohling, and Penland, 2009). Located approximately $40 \mathrm{~km}$ (25 mi) offshore of the Louisiana mainland wetlands across Breton and Chandeleur Sounds, the islands are inherently susceptible to the effects of tropical storms entering the northern Gulf of Mexico and have been impacted by more than 40 hurricanes since the early 1900 s.

Long-term sediment-transport trends are punctuated by nearly instantaneous restructuring during storm events. This was dramatically demonstrated at the Chandeleur Islands in the wake of Hurricane Katrina (2005), where storm surge inundated the islands and completely removed the subaerial sand, leaving discontinuous marsh islets (Sallenger and others, 2007). Miner, Kulp, Penland, and others (2009) reported that shoreline change related to storm impact significantly exceeds long-term change trends, and Fearnley, Miner, Kulp, Bohling, Martinez, and other, (2009) showed that the Chandeleur Islands lost the same amount of land between 1855 and 1996 as between 1996 and 2005 (fig. 39). The

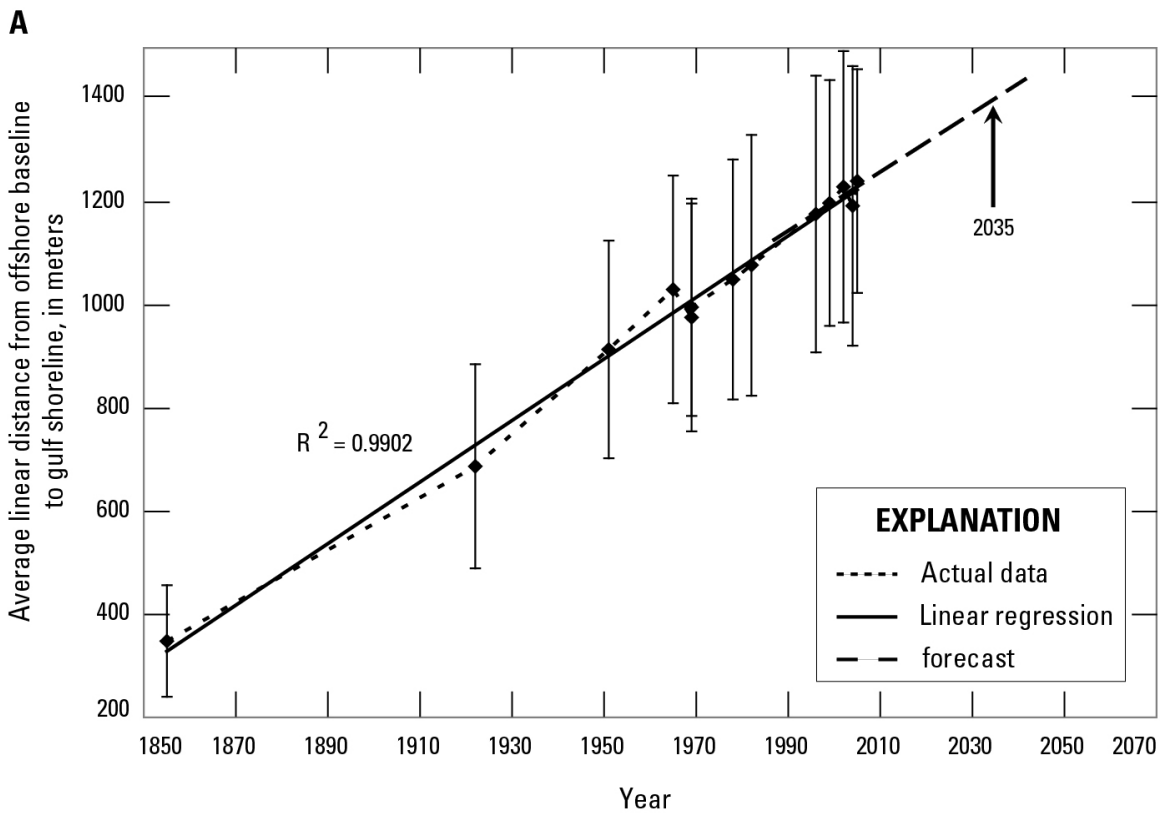

B

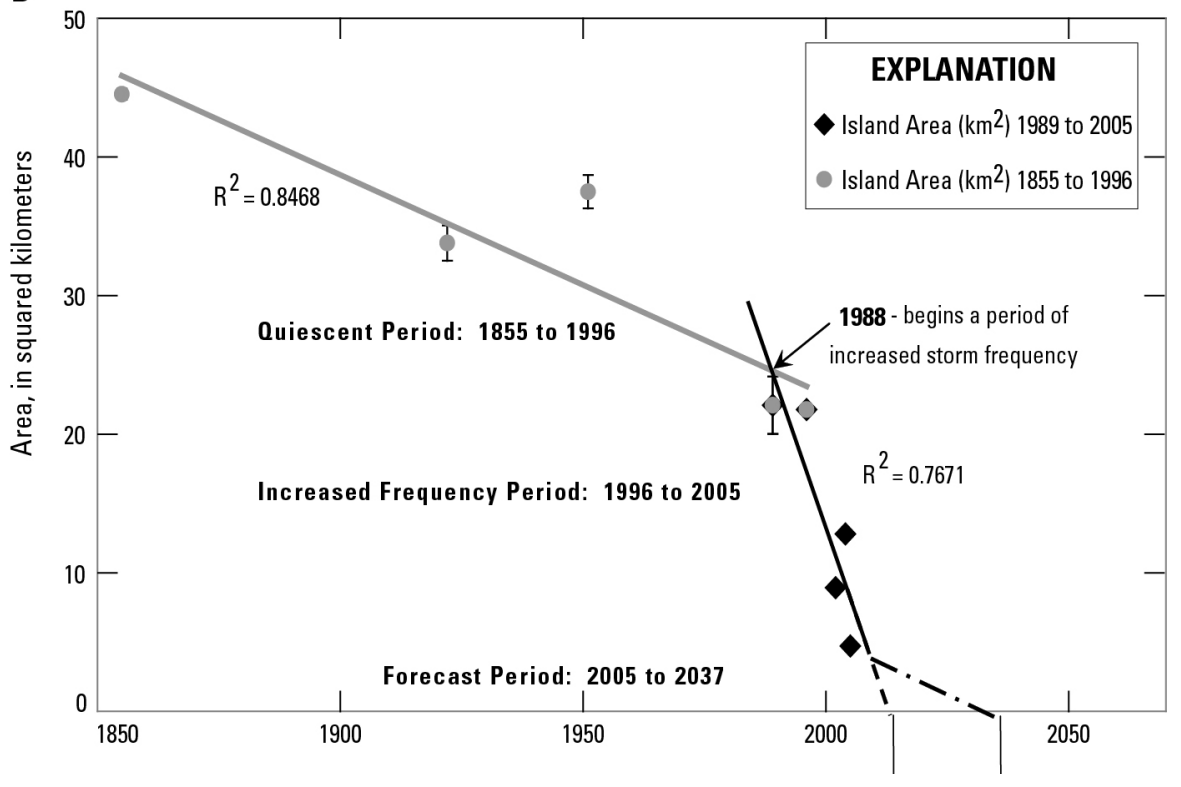

Figure 39. Shoreline-retreat and landarea change for the Chandeleur Islands between 1855 and 2005. (A) Average linear distance from the shoreline (at a given year) to an offshore baseline. In 2035, the shoreline is projected to erode to the bayside position of the islands, and the marsh is expected to disappear. (B) Using the frequencies of storm activity affecting the northern Chandeleur Islands and historical shorelines, land area was plotted for two periods: 1855-1996 (gray line) and 19892005 (black line). These trends show two different trajectories for island survival (from Fearnley, Miner, Kulp, Bohling, and Penland, 2009). Abbreviation: km, kilometer. 
historical (1855 to 1996) loss included changes caused by the passage of Hurricane Camille in 1969, which passed over the Chandeleur Islands as a Category 5 storm. Recently, Hurricanes Ivan (2004) and Katrina (2005) decimated the islands, reducing surface area by an average rate 10 times greater than in the previous century (Fearnley, Miner, Kulp, Bohling, Martinez, and Penland, 2009; Sallenger and others, 2009). Comparing the increased destruction to the Chandeleur Islands caused by Hurricanes Katrina and Ivan relative to Camille, Fearnley, Miner, Kulp, Bohling, Martinez, and Penland (2009) concluded that hurricane frequency and trajectory relative to island curvature and structure are as important as hurricane intensity.

In addition to the historical shoreline data compiled for the BICM project, Fearnley, Miner, Kulp, Bohling, Martinez, and Penland (2009) used historic maps from between 1744 and 1848 to determine the historical position of the Chandeleur Islands. The geomorphic response of the shoreline during the past century was investigated by using maps from five time periods: 1855, 1922, 1989, 2004, and 2005. For a comprehensive documentation of methods, uncertainty analysis, and measurement accuracy, see Fearnley, Miner, Kulp, Bohling, and Penland (2009), McBride and others (1992), Morton and others (2004), and Martinez, Penland, and others (2009b).

Results of historical (1855 to 2005) shoreline-change analyses conducted by Fearnley, Miner, Kulp, Bohling, and Penland (2009) for the Chandeleur Islands are consistent with the conclusions of Miner, Kulp, Penland, and others (2009): storm frequency and extreme storm impacts dominate the long-term evolution of island area and shoreline retreat (fig. 39). Prior to 1996, storm frequency was low, and island area changed at a relatively low rate of $-0.16 \mathrm{~km}^{2} / \mathrm{yr}^{2}$ $\left(-0.062 \mathrm{mi}^{2}\right)$; however, the rate increased to $-1.01 \mathrm{~km}^{2} / \mathrm{yr}\left(-0.39 \mathrm{mi}^{2}\right)$ when the number of storms impacting the shoreline increased between 1996 and 2005. Shoreline-retreat rates also increased from a rate of $-11.4 \mathrm{~m} / \mathrm{yr}(-37.4 \mathrm{ft} / \mathrm{yr})$ between 1922 and 1996 to $-41.9 \mathrm{~m} / \mathrm{yr}(-137.5 \mathrm{ft} / \mathrm{yr})$ between 1982 and 2005. The passage of Hurricane Katrina in 2005 produced an unprecedented erosional impact when compared to pre-storm observations. The shoreline of the northern Chandeleur Islands eroded and moved landward by $-201.5 \mathrm{~m} / \mathrm{yr}(-661.1 \mathrm{ft} / \mathrm{yr})$, compared with an average rate of $-38.4 \mathrm{~m} / \mathrm{yr}(-126$ $\mathrm{ft} / \mathrm{yr}$ ) between 1922 and 2004. Based on their analysis of historical land-area trends (fig. 39), Fearnley, Miner, Kulp, Bohling, and Penland (2009) projected that the Chandeleur Islands could potentially lose all marsh area by 2013 if tropical storms continue to impact the islands at rates observed between 1996 and 2005. However, if storm frequency returns to pre-1996 conditions, the back-barrier marshes may persist through 2037 (Fearnley, Miner, Kulp, Bohling, and Penland, 2009).

Analysis of BICM bathymetric data from the Chandeleur Islands (Miner, Kulp, Weathers, Motti, and others, 2009) identified long-term trends of barrier-shoreface retreat and land loss that are consistent with the long-term shorelinechange analyses presented by Fearnley, Miner, Kulp, Bohling, and Penland (2009). Volume calculations by Miner, Kulp, Weathers, Motti, and others (2009) indicate that about $150 \times 10^{6} \mathrm{~m}^{3}\left(196 \times 10^{6} \mathrm{yd}^{3}\right)$ of sediment have been deposited downdrift (northward) and seaward of the northern terminal spit during the past 125 years (fig. 40). At the southern end of the island chain (south of Breton Island), a similar volume of sediment has accreted (Miner, Kulp, Weathers, and Flocks, 2009). The volume of sediment deposited in the back-barrier environment (via cross-shore transport), however, is only half that distributed by alongshore currents to the flanks. Sediment-accretion rates of the flanking depositional sinks are more than $1.0 \times 10^{6} \mathrm{~m}^{3} \mathrm{yr}^{-1}\left(1.3 \times 10^{6} \mathrm{yd}^{3} \mathrm{yr}^{1}\right)$ between 1870 and 2007 (Miner, Kulp, Weathers, and Flocks, 2009). The sediment sources for the flanking depositional centers include (1) relict deltaic deposits eroded from the shoreface where significant erosion has occurred since 1870 and (2) nearshore and subaerial barrier sand. Miner, Kulp, Weathers, and Flocks (2009) concluded that long-term shoreline erosion and transgressive submergence are primarily associated with major storms and that rapid land loss accompanies these high-energy events. Seasonal nearshore currents transport sand to the flanks of the arc, removing it from the littoral system, and the islands are unable to fully recover from storm impacts. These downdrift sand reservoirs provide a unique, quasi-renewable potential resource for restoring the updrift barrier system if used in a practical coastal management plan.

The impact of Hurricane Katrina on the Chandeleur Islands in 2005 has been well documented. Sallenger and others (2009) studied geomorphic changes to the islands following the storm landfall by using multiple lidar surveys and additional BICM data. A summary of their study follows, and the full publication can be found in Lavoie (2009).

Sallenger and others (2009) found that nearly 2 years after Hurricane Katrina removed 86 percent of the subaerial surface area of the Chandeleur Islands, most of the island chain continued to rapidly erode (fig. 41). The hurricane impact triggered feedback processes that intensified shoreline erosion even under relatively mild, post-storm conditions. These processes were triggered during the hurricane storm surge, which completely submerged the islands. Sallenger (2000) described this "inundation regime," and noted that when such submergence occurs, it can lead to differential water levels in the bay across the island and offshore, forcing currents to erode narrow beaches or inlets, connecting the back-barrier bay with the open ocean. Sallenger and others (2009) showed that during Hurricane Katrina, the Gulf of Mexico-facing shorelines were eroded landward an average of $268 \mathrm{~m}$ (879.3 ft) (fig. 42). Peak dune elevations on the islands decreased 


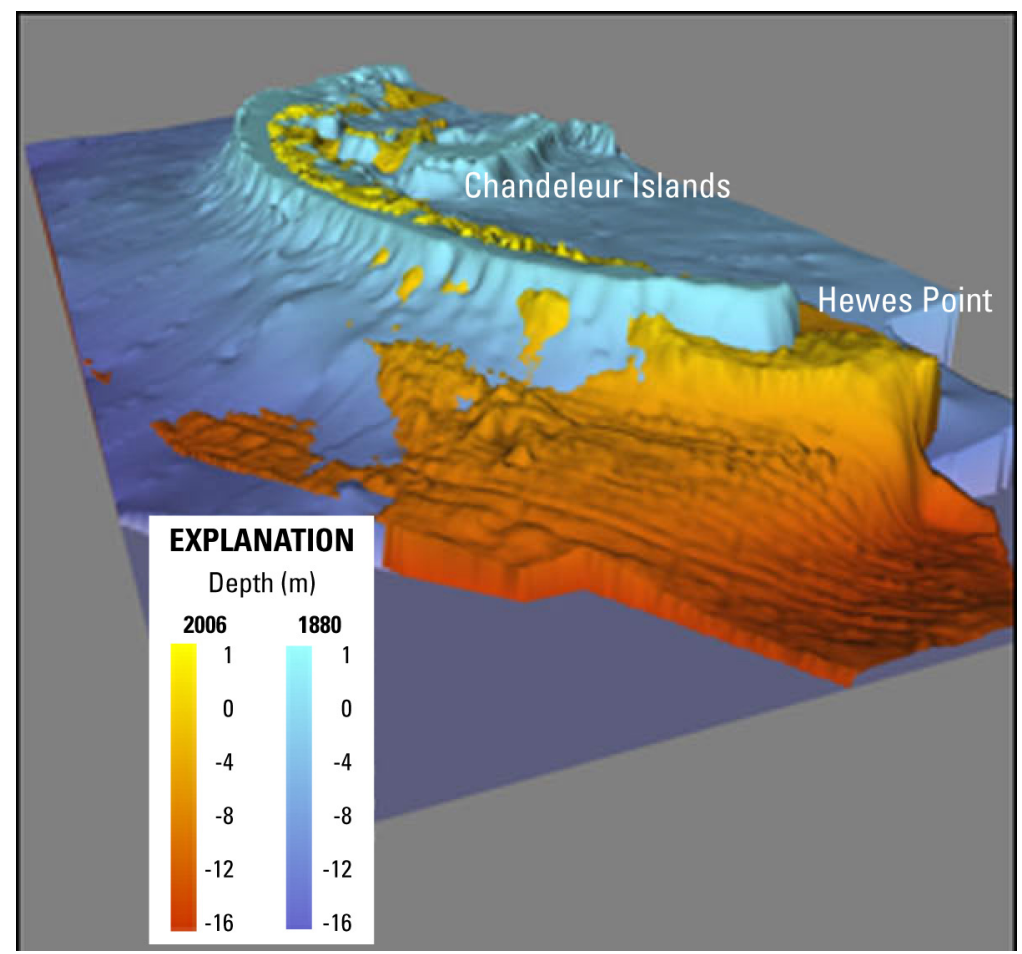

Figure 40. View to the south of the seafloor surfaces of the Chandeleur Islands of the 1870s (blue) versus those of 2006 (orange). Note the large accretionary zone north of Hewes Point (orange in foreground) (modified from summary in Lavoie, 2009). Abbreviation: $\mathrm{m}$, meter.

from $>6 \mathrm{~m}(19.6 \mathrm{ft})$ to $<3 \mathrm{~m}(9.8 \mathrm{ft})$, and sand was removed from the island surface, exposing remnant marsh platforms that were subsequently degraded by relatively small waves. Although some sand had been deposited on the islands by June 2007, elevations had not rebuilt appreciably, and the Chandeleurs remained vulnerable to inundation by weak storms. Limited sand supply and rapid sea-level rise means it is likely that the Chandeleur Islands will continue to experience extreme erosion and will ultimately become completely submerged.

\section{Impacts of Hurricanes and Implications for Management}

Numerous recent studies of the Chandeleur Islands have established that the islands are sand starved. Their original sediment source was fluvial sediments from the St. Bernard delta lobe (Penland and others, 1988). About 2,000 years ago, the Mississippi River shifted course, diverted westward, to the location of the Lafourche delta complex. This natural transgression initiated a new stage of the St. Bernard delta complex, as coastal submergence and wave action started to form the Chandeleur Islands (Penland and others, 1988; Ritchie and Penland, 1988). As waves and currents reworked the delta lobe, sand was concentrating into a headland beach or being deposited in spits that formed to either side of the headland, such as Hewes Point to the north. As natural subsidence continued, the back-barrier marshes were submerged and the headland detached from the mainland, forming the Chandeleur Islands. With continued subsidence and sand starvation, the islands are forecast to become smaller and lower and eventually become a submerged shoal (Penland and others, 1988). Submergence of the islands is accelerated by storm impact, and Sallenger and others (2009) report that the islands response to Hurricane Katrina reveal failure modes that may ultimately contribute to the demise of the Chandeleur Islands. Hurricane Katrina stripped sand from the islands, exposing the muddy marsh platforms to waves and leading to rapid erosion (Sallenger and others, 2009).

The impact of Hurricane Katrina on the Chandeleur Islands was an unprecedented erosional event and highlights the vulnerability of the Chandeleur Islands to major storms. Fearnley, Miner, Kulp, Bohling and other (2009) analyzed measurements available between 1855 and 2005 and showed that the Chandeleur Islands area can be expected to convert to ephemeral barrier island/shoals between 2013 and 2037 (fig. 39). In addition to storm frequency, a key factor governing shoreline response to storm impact is the trajectory of the storm track with respect to the position of the islands. The highest rates of shoreline erosion are caused by storms that pass within $120 \mathrm{~km}$ (75 mi) to the west of the islands; a relatively small amount of shoreline erosion is caused by storms that pass more than $120 \mathrm{~km}$ (more than $75 \mathrm{mi}$ ) to the east.

Curlew and Grand Gosier Islands in the southern part of the barrier-island arc reflect the future of the Chandeleur Islands. Curlew and Grand Gosier Islands have been reduced to submerged shoals as a result of the high storm frequency 


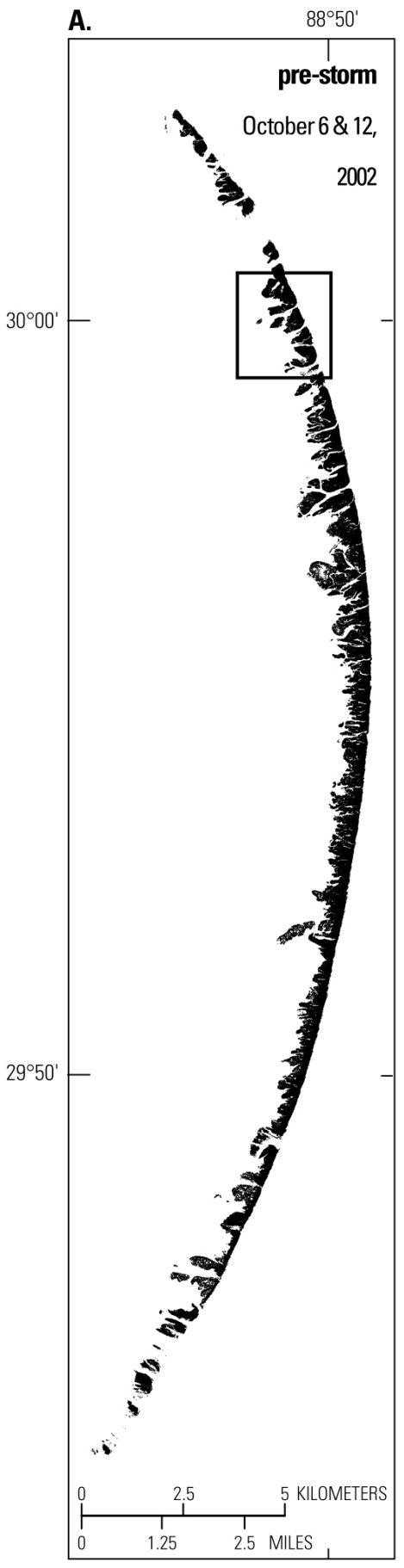

B.

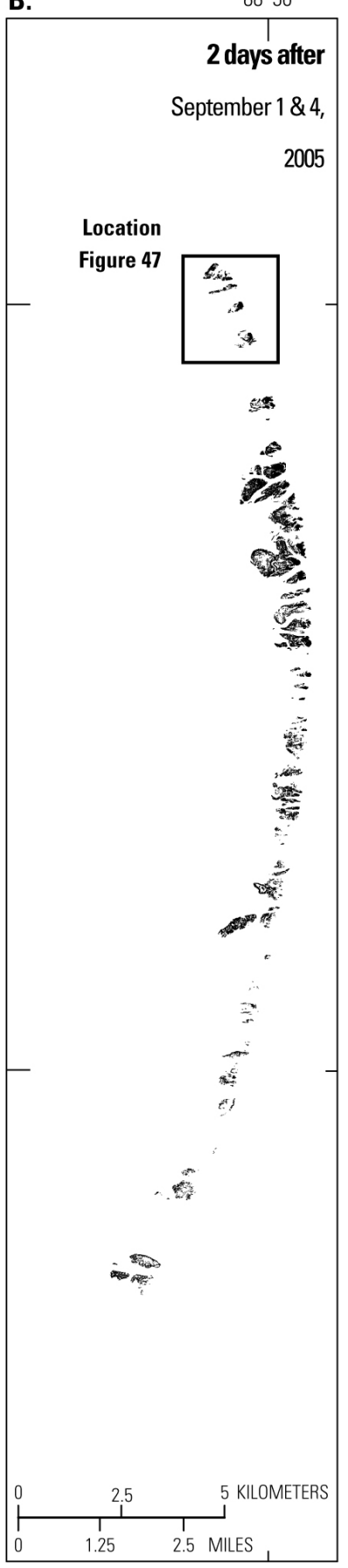

C.

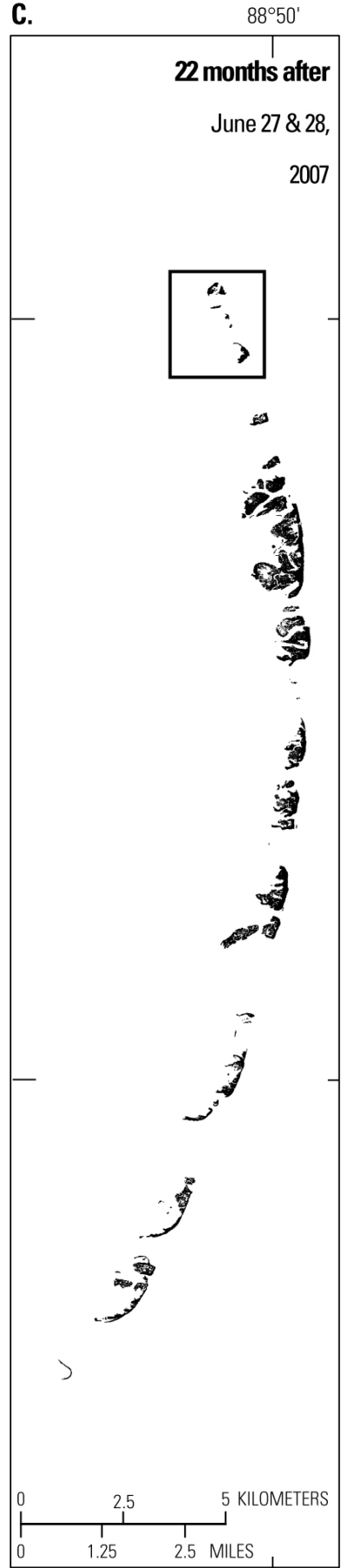

Figure 41. Maps of the Chandeleur Islands before and after Hurricane Katrina (August 2005) based on lidar data. The island areas represent elevations above mean high water (MHW); elevations below MHW are white. (A) Lidar survey from before Hurricane Katrina acquired by using the National Aeronautics and Space Administration (NASA) Airborne Topographic Mapper on October 6 and 12, 2002; referred to in the text as the "pre-storm" survey. (B) Survey within several days of the landfall of Katrina taken by using the NASA Experimental Advanced Airborne Research Lidar (EAARL) from September 1 and 4, 2005; referred to in the text as the survey 2 days after. (C) Survey nearly 2 years after landfall taken by using the NASA EAARL on June 27 and 28, 2007; referred to in the text as the survey 22 months after. 

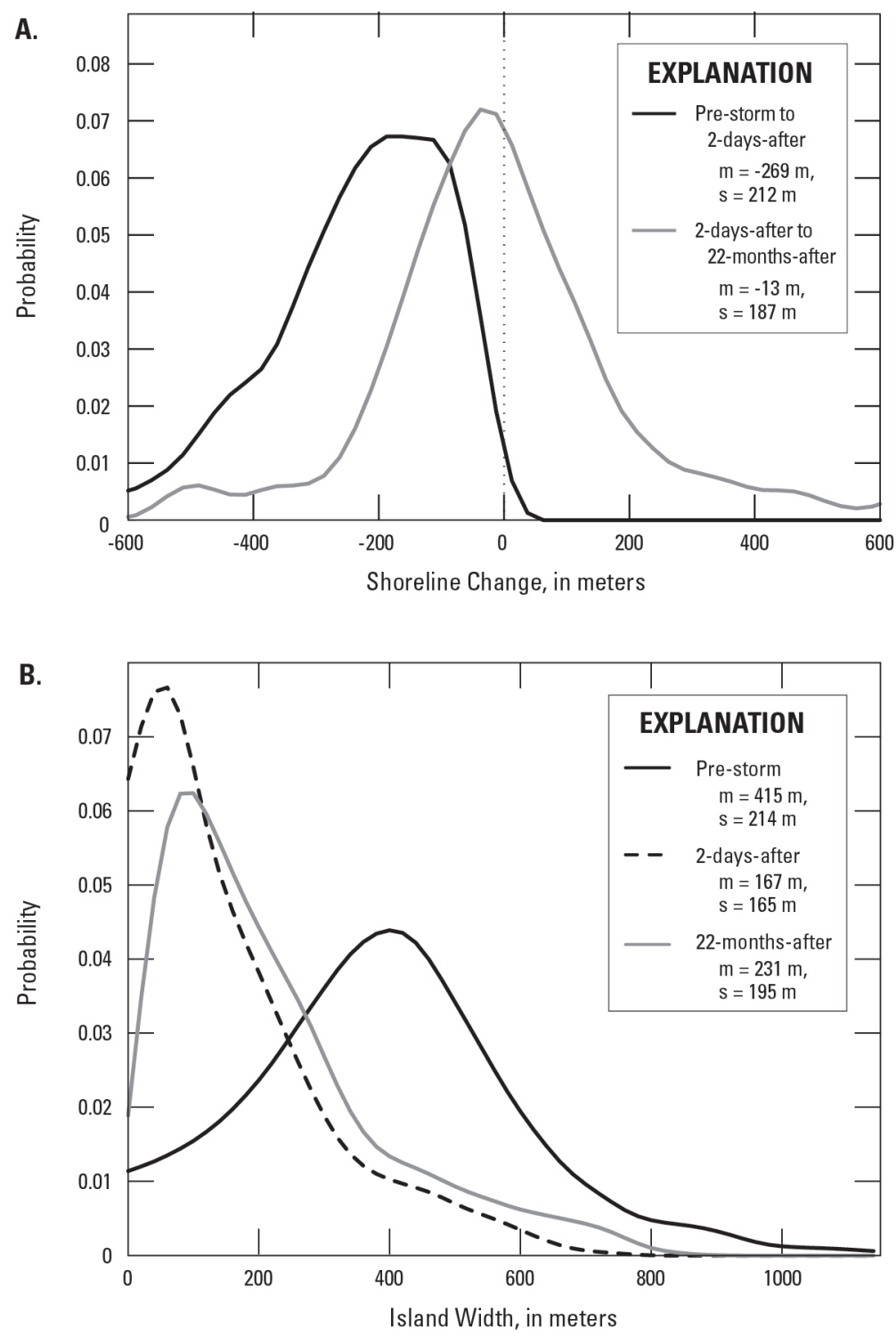

Figure 42. Changes of the shoreline $(A)$ and width (B) of the Chandeleur Islands from lidar surveys before Hurricane Katrina (August 2005), 2 days after the storm, and 22 months after the storm. Abbreviation: $\mathrm{m}$, meter.

and diminished sand supply during the past decade. These ephemeral islands have undergone submergence in the past as a result of storm impacts, including erosion of their marsh platform, and subsequently reemerged during periods of calmer weather. The ephemeral nature of these islands is attributed to the absence of a stabilizing back-barrier marsh (Miner, Kulp, Weathers, and Flocks, 2009). As the northern islands erode and island areas are reduced to only sandy shoreline deposits with little or no back-barrier marsh, they will begin to behave similarly to the southern ephemeral islands.

Miner, Kulp, Weathers, and Flocks (2009) and Lavoie (2009) observed that during the post-storm recovery period, landward transfer of sand is facilitated by (1) landward migration of offshore bars that weld to marsh islets, (2) recurved spit formation at hurricane-cut inlets, (3) eolian processes (dunes, wind tidal flats, and deposition on the marsh surface), and (4) shoal aggradation and landward migration. The dominance of lateral transport over cross-shore transport is important, as sand is being concentrated in thick sediment bodies at the flanks of the island arc (fig. 40, Twichell and others, 2009a). By understanding where the sand is going, how long it takes to get there, and how the islands respond to a rapid introduction of new sediment, more efficient barrier management strategies can be developed. Lavoie (2009) suggested that restoration goals should mimic the natural processes of early stages of barrier island evolution (fig. 43), using natural coastal currents to transport sand laterally to the island flanks from a centralized source. This method would ultimately enhance the islands' ability to naturally build back-barrier marsh, dunes, and a continuous sandy shoreline. Barrier-island sediment nourishment should be executed with the understanding that gulf-side shoreline erosion is inevitable; however, in principle, island area can be maintained and enhanced during retreat with strategic sand placement. 

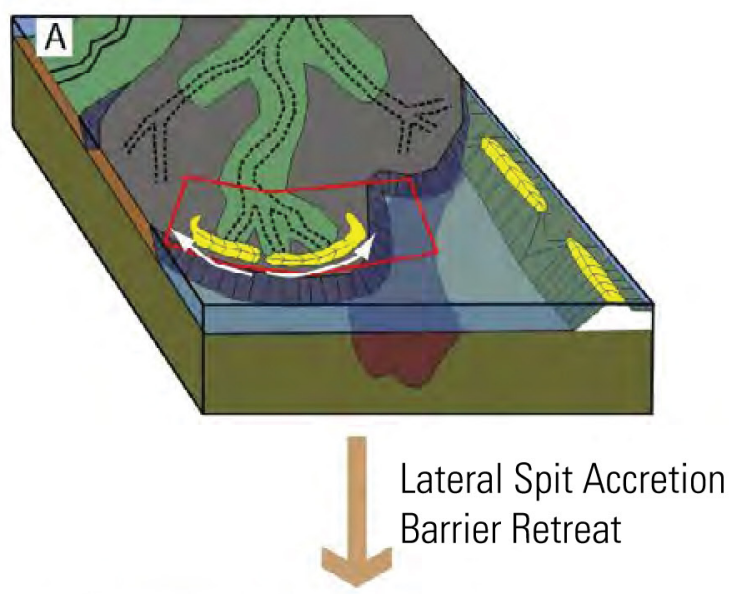

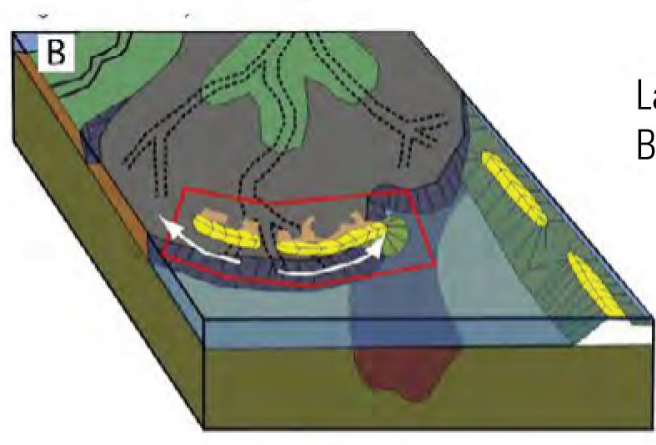

Transgressive

Submergence

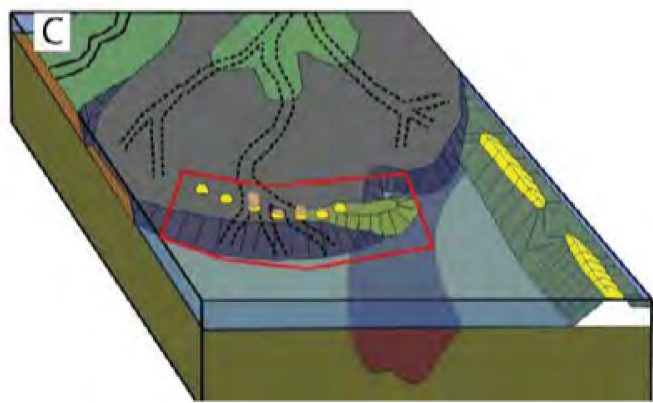

Lateral Spit Accretion Barrier Retreat

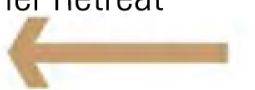

Natural Reworking Backbarrier Marsh Expansion

\section{Restoration}

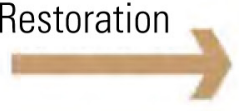

Figure 43. Conceptual model demonstrating how a barrier-island management-restoration approach may employ natural physical processes to extend the life span of the Chandeleur Islands. The model is based on the Twichell and others (2009a) model that was interpreted from geophysical and sedimentological data. (A) Barrier-island formation is the natural result of sediment deposition from an abandoned deltaic headland. (B) Continued wave reworking of the sediment that is sourced from a headland or islands. (C) Sediment is transported alongshore to the flanks of the island system, leading to the eventual removal of sediment from the littoral system and forcing island erosion and submergence. (D) In the case of the Chandeleur Islands, utilizing and placing sediment from the "sediment sink" to the north (Hewes Point - HP) and the offshore sediment source from the St. Bernard Shoals (STB) may reverse the process of transgressive submergence. (E) The strategically and centrally placed sand will be naturally distributed by longshore currents to close inlets, broaden beaches, and increase dune elevations, making sand available for overwash and spit building upon which back-barrier growth of marsh vegetation can occur. Placing this sand updrift of the sand that was lost from the system may effectively reset the clock to stages A-B. 


\section{THEME 3: Impact of Tropical Storms on Barrier-Shoreline Elevations and the Response of Island Renourishment to Storms}

Hurricanes frequently impact coastal Louisiana causing widespread coastal change (fig. 44). Theme 2 discussed the changes that hurricane impacts can cause to barrier island morphology and the possibility of island recovery to prestorm conditions. In this theme the oceanographic and geologic processes that impact a coastal system during the passage of a storm will be discussed. Since oceanographic and geologic processes cannot be discussed completely separate from geomorphology, there is some overlap. As with the previous themes, the Chandeleur Islands, in particular, are used as proxy for the Louisiana coastal system because of the extensive data that are available.

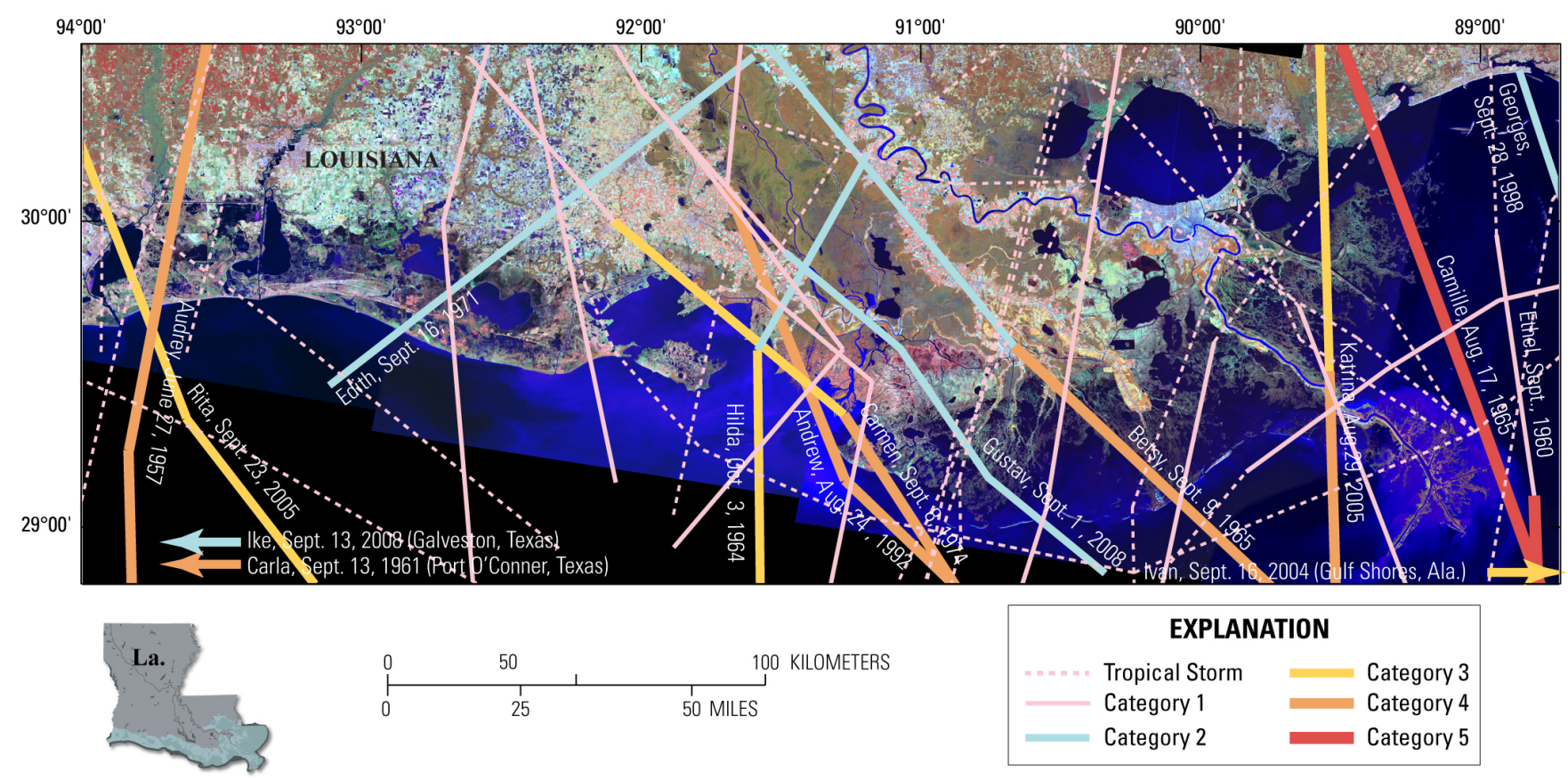

Figure 44. Hurricane and tropical storm tracks that impacted the Louisiana coast over the 50-year time period between 1957 and 2008. Source of storm tracks is the National Oceanic and Atmospheric Administration (2010).

The size, intensity, duration, transit speed, and precipitation of tropical storms are highly variable. These variations drive the physical processes that influence coastal evolution. Factors that produce different responses include (1) the profile across the island and nearshore of a new construction may not be in equilibrium with the natural system and (2) the sediment grain-size of the source is different from the native sediment. Once a constructed barrier island or shoreline with appropriate sediment grain size has matured and reached equilibrium, it responds similarly to a storm as a natural barrier island or shoreline. For this discussion, it is assumed that natural and constructed barrier islands and shorelines respond similarly.

The following discussion summarizes several publications that addressed coastal response to tropical storms, many of which used data from the BICM project. Since the 1980s, several studies have documented the rapid landward migration and degradation of barrier islands and abandoned deltaic-headland shorelines in the Louisiana coastal zone (for example, Penland and others, 1988; Williams and others, 1992). Processes associated with the transgressive phase of the delta cycle (Roberts, 1997; Penland and others, 1988) including high rates of delta-plain subsidence, a paucity of sand, and interior-wetland loss, coupled with climatic factors such as eustatic sea-level rise and frequent large-magnitude storm impacts, collectively contribute to barrier degradation in Louisiana (Penland and Ramsey, 1990; McBride and others, 1992; List and others, 1994, 1997; FitzGerald and others, 2007; Miner, Kulp, FitzGerald, Flocks, and Weathers, 2009; Fearnley, Miner, Kulp, Bohling, and Penland, 2009). Some significant processes are undetectable in the absence of 
a regional-scale investigation covering long time periods (Sallenger and others, 1992; List and Terwindt, 1995). While the manifestation of processes that drive transgression in the delta plain are well studied and monitored at the surface, the seafloor response and the role of seafloor-sediment dynamics in short- and long-term coastal evolution are not as well understood. To more effectively identify the magnitude, rates, and processes of coastal evolution in Louisiana, BICM was designed and implemented as a framework for a coast-wide monitoring effort.

As reported in Theme 1, before implementation of the BICM project in Louisiana, the only available regionally consistent documentation of bathymetry, sediment transport, and seafloor change was presented in List and others (1994). During the two decades that followed that compilation, storm intensity and frequency along the Louisiana coast increased significantly (Fearnley, Miner, Kulp, Bohling, and Penland, 2009). As a result of its geographic location, the Louisiana coast is susceptible to the effects of almost any major storm entering the northern Gulf of Mexico and has been impacted by more than 50 hurricanes since the 1850 s.

The first manifestation of storms typically observed is shoreline erosion. Shoreline erosion is an easily measurable retreat of the shore along the perimeter of a water body that has substantial fetch to storm waves. The Gulf Coast has been impacted by 14 hurricanes over the past decade, and each of these storms caused observable changes to the coast; some stretches recovered naturally within months, whereas other changes persisted for several months or years. Sallenger (2000) used storm wave-run-up elevation and still-water elevation (which includes storm surge, wave setup, and astronomical tide) relative to the peak elevation of the foredune to show that the magnitudes of change can be scaled. Sallenger concluded that as the run-up and still-water elevation increase, thresholds that define regimes of increasing impact magnitude will be crossed. These impact regimes progress from run-up colliding against the dune and eroding it landward, to run-up overwashing the dune, to still-water level completely submerging the beach system (fig. 45; A.H. Sallenger, Jr., oral commun., June, 2012). The greatest coastal changes have been observed following complete submergence, which can occur locally on a barrier island and can scour inlets, as occurred during Hurricanes Camille (1969), Charley (2004), Ivan (2004), and Katrina (2005), or can submerge tens of kilometers of coast, as occurred on the Bolivar Peninsula, Texas, during Ike (2008) and on the Chandeleur Islands during Katrina (2005).

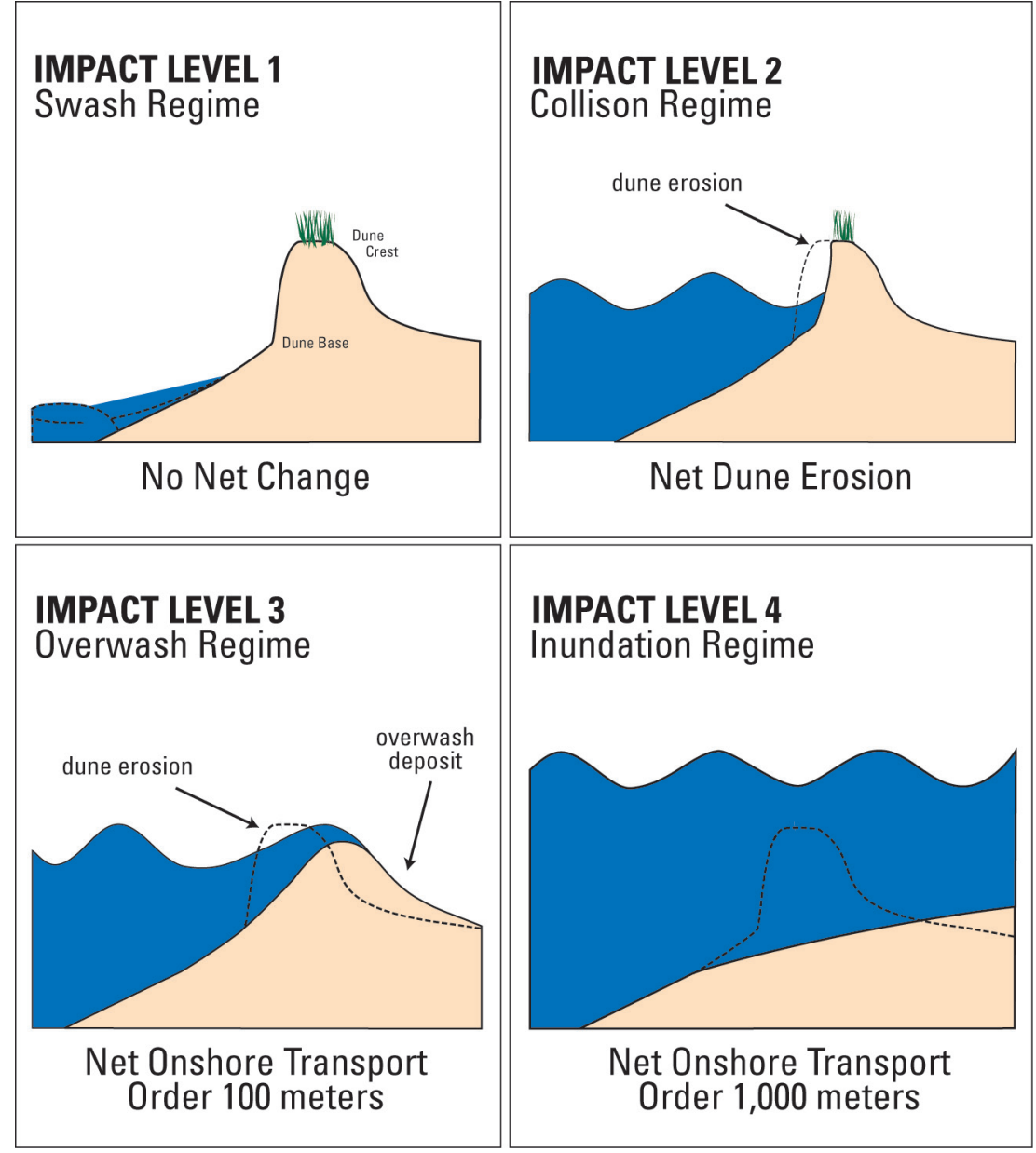

Figure 45. Erosion of a barrier island is a function of elevation compared to total water run-up, for example, surge+setup+runup on the beach (Sallenger, 2000). The inundation regime can submerge tens of kilometers of coast, as occurred on the Bolivar Peninsula, Texas, during Hurricane Ike (2008) and on the Chandeleur Islands during Katrina (2005). 
The most complete analysis of Louisiana barrier-island storm response and recovery to date has been by Sallenger and others (2009), who analyzed the impact of Hurricane Katrina and recovery of the Chandeleur Islands. Katrina was an Impact Level 4 on the Sallenger scale (fig. 45). The Katrina storm surge along the Mississippi coast approached $10 \mathrm{~m}$ (32.8 ft) (Knabb and others, 2005, reported that the highest measured watermark was near Bay St. Louis, Mississippi, at $8.5 \mathrm{~m}, 27.9 \mathrm{ft}$.) Sallenger and others (2009) reported that peak surges along the Chandeleur Islands were smaller, ranging from about $3 \mathrm{~m}(9.8 \mathrm{ft})$ in the south to nearly $4 \mathrm{~m}(13.1 \mathrm{ft})$ in the north. Setup associated with wave breaking on the Gulf

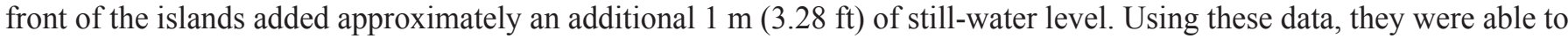
calculate that the storm surge height was sufficient to submerge the southern half of the island chain; in the northern half, peak island dune elevations emerged through the combined surge and setup (fig. 46). The total elevation of wave run-up on the beach, however, was sufficient to overtop pre-storm peak elevations along the entire length of the islands (fig. 46). Therefore, during the early stages of the storm, the entire area of the islands was periodically overwashed by waves, driving sand from beaches and dunes from the Gulf side toward the Chandeleur Sound side.
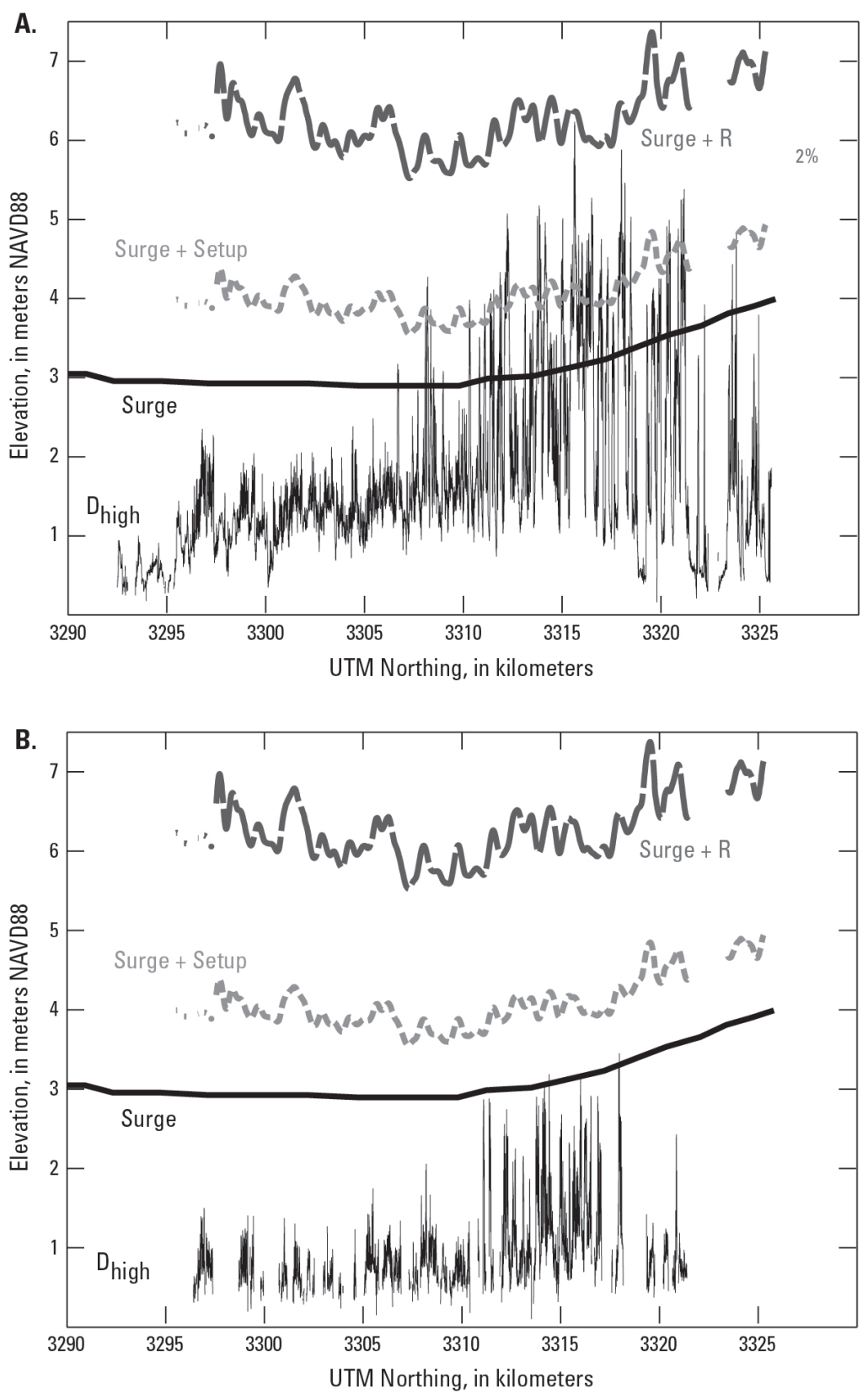

Figure 46. Peak elevations (Dhigh) determined every $20 \mathrm{~m}(67 \mathrm{ft})$ along the length of the Chandeleur Islands using lidar data processed for first return. Only first return is available for the "pre-storm" survey, so even though bare-earth data are available for 2 days after Hurricane Katrina in 2005, the first return is shown here to be comparable with pre-storm data. Also shown are storm-surge elevations along the shore as determined by NOAA using the Sea, Lake, and Overland Surges from Hurricanes (SLOSH) model, surge plus calculated wave setup, and surge plus extreme (2\%) wave run-up. (A) "Pre-storm" (merged 2001 and 2002) Dhigh determined from lidar data acquired with the NASA Airborne Topographic Mapper. (B) Dhigh from 2 days after the storm determined from lidar data acquired with the NASA Experimental Advanced Airborne Research Lidar (from Sallenger and others, 2009). 
During the storm peak, dune elevations were reduced (compare figure 46A with B) because of inundation and overwash. At the peak of the storm, the still-water level was sufficient to completely submerge the islands (Sallenger, 2000; fig. 45, Impact Level 4). Differences in sea level between the Gulf and Sound likely drove currents across the island shoals and contributed to the net transport of beach and dune sand from the islands, exposing the underlying marsh platforms.

In the aftermath of tropical storms, beaches typically recover naturally to some extent. Recovery processes include sand migrating onshore in swash bars and welding onto the beach during the weeks and months after the event (Owens and Frobel, 1977). During the 22 months after Katrina's landfall, repeated lidar surveys showed that the islands did not recover uniformly, instead 56 percent of the Gulf-side shore continued to retreat landward, and the islands progressively retreated landward between successive lidar surveys (fig. 47). At one location, the total retreat was almost $500 \mathrm{~m}$ (1,640 ft) (Sallenger and others, 2009).

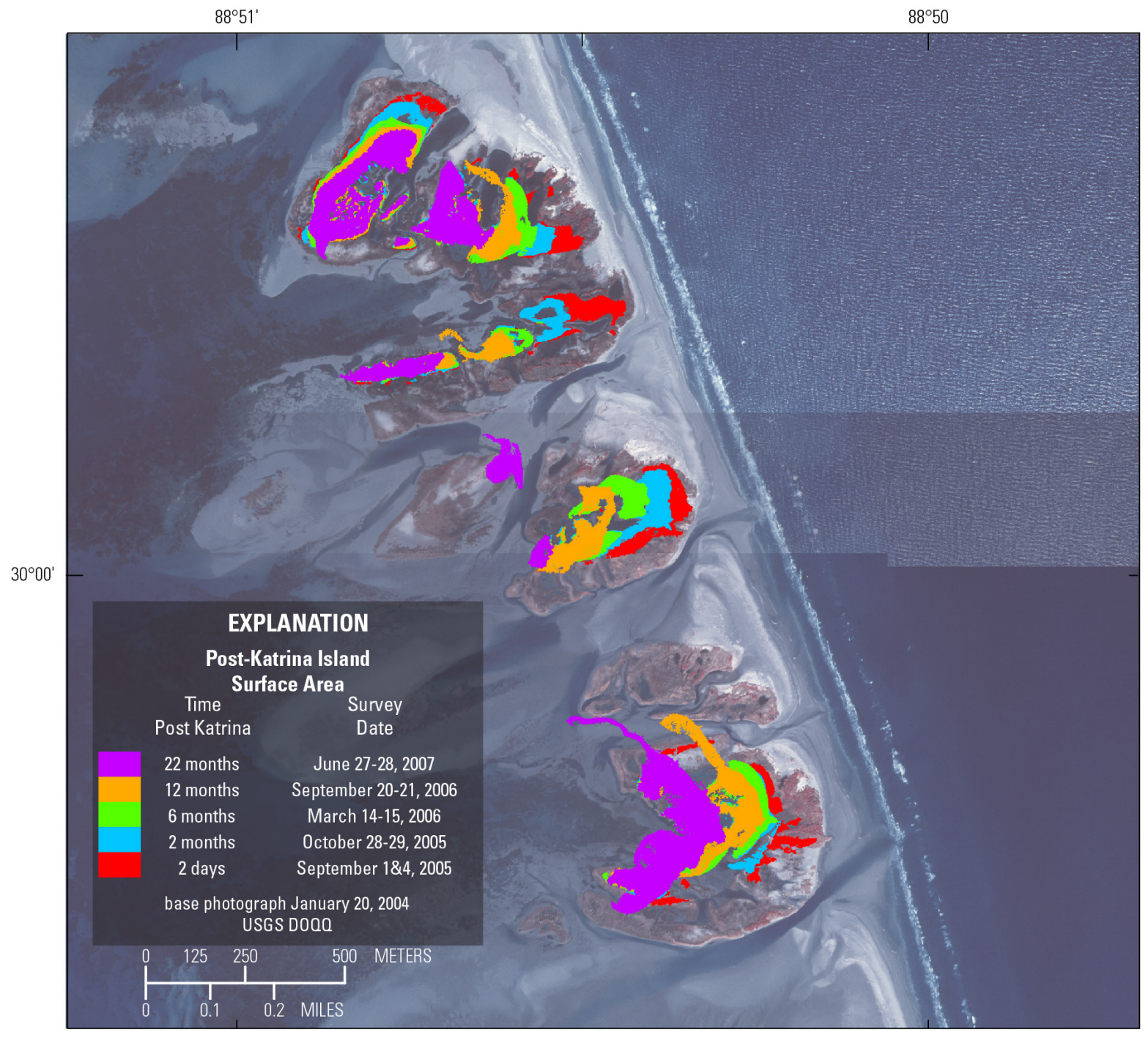

Figure 47. Changes to a 2.5-km (1.6-mi) reach of the Chandeleur Islands showing persistent erosion and landward retreat during the 22 months after landfall by Hurricane Katrina (modified from Sallenger and others, 2009). The base map is a rectified, vertical photograph from before the storm, January 20, 2004. A time series of lidar maps is overlain on the photograph; with more recent surveys overlaid on previous surveys. If no change occurred, only the last survey (purple) would be visible. Erosion is shown between 2 days after (red) and 2 months after (blue). 
The muddy composition of nearshore sediments likely contributed to the continued rapid erosion and retreat following the storm. With the sand stripped from the islands, the muddy-marsh fragments that remained were exposed to the surf of the Gulf of Mexico and were vulnerable to erosion even by the relatively low post-Katrina waves. These marsh fragments contained a low percentage of sand and as the marsh shore eroded landward, the sand was released and made available to form incipient beaches, while the muddy fine sediments in the eroded marsh continued to disperse. Over time, these beaches will provide a veneer of sand that is likely to buffer the marshy shore from continued rapid erosion.

The 44 percent of the Gulf shore that did not continue to erode over the 22 months after the storm showed the development of spits and welded swash bars that advanced the shore seaward. At one location, a beach developed seaward of the shoreline position, prograding the shoreline after the storm as much as $100 \mathrm{~m}(328 \mathrm{ft})$ seaward. Where accretion occurred, the islands widened from an average of $167 \mathrm{~m}$ ( $548 \mathrm{ft}, 2$ days after) to $231 \mathrm{~m}$ ( $758 \mathrm{ft}, 22$ months after). However, the overall mean shoreline change for the islands over the same period was $13 \mathrm{~m}(40.6 \mathrm{ft})$ of erosion.

Bare-earth lidar elevations (vegetation removed) acquired 2 days after and 22 months after the storm measure peak elevations on the islands. Immediately after the storm, island elevations averaged about $1 \mathrm{~m}$ (3.28 ft, fig. 48A); 22 months later, elevations had increased by only $0.3 \mathrm{~m}(0.98 \mathrm{ft}$, fig. 48B and C). Also shown on these plots are the worstcase (maximum-of-the-maximum) storm-surge elevations for Category 1 through Category 3 hurricanes, as well as the surge simulated by NOAA using the Sea, Lake, and Overland Surges from Hurricanes (SLOSH) model and Katrina conditions.

Post-storm island elevations were lowered sufficiently to be vulnerable to complete submergence (inundation regime, Impact Level 4, fig. 45) by a Category 1 hurricane. Nearly 2 years later, island elevations along a portion of the northern Chandeleur Islands had recovered enough to be emergent through a Category 1 surge; with the rest of the islands vulnerable to inundation. The implication is that islands or shorelines that have been stripped of sand, exposing the

A.

2 days Post-Storm Bare Earth Elevations

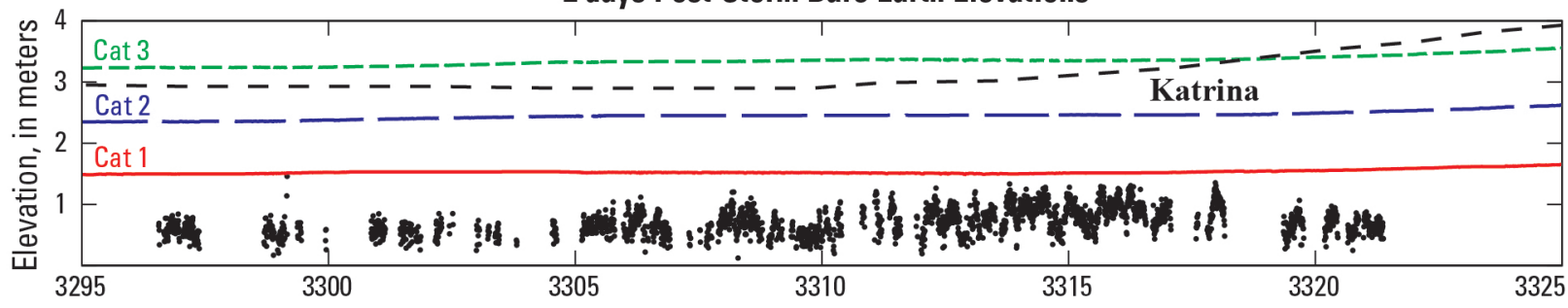

B.

22 months Post-Storm Bare Earth Elevations

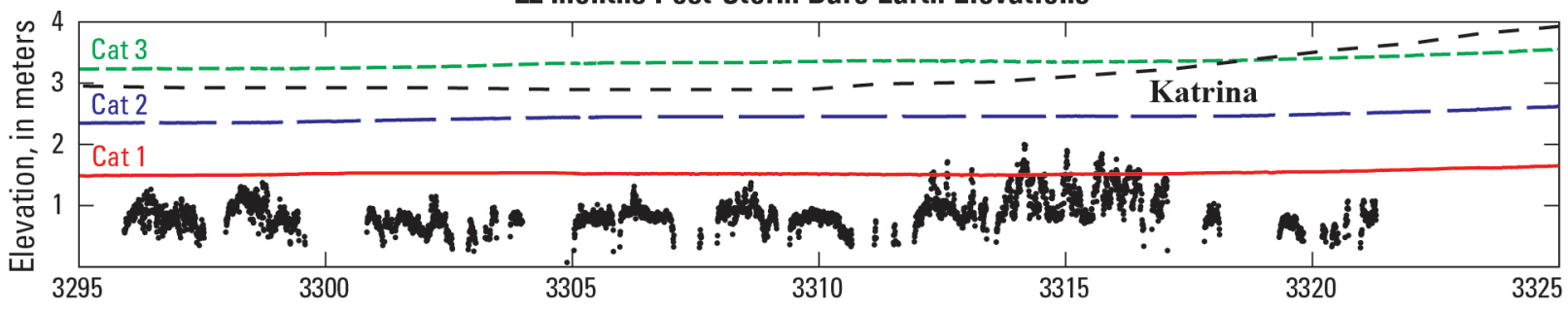

C.

22 months minus 2 days Bare Earth Max Elevations

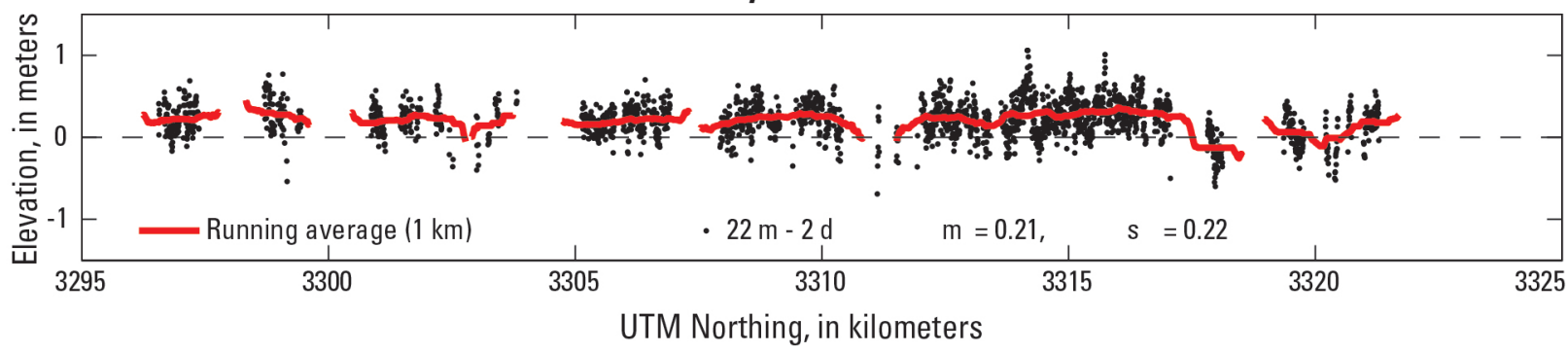

Figure 48. Bare-earth peak elevations (Dhigh), maximum-of-the-maximum storm-surge elevations for different categories ("cat") of hurricanes, and storm surge for Hurricane Katrina computed by using the Sea, Lake, and Overland Surges from Hurricanes (SLOSH) model. (A) 2 days after. (B) 22 months after. (C) Change in Dhigh between 2 days after and 22 months after (Sallenger and others, 2009). 
marsh platform base, are highly vulnerable to inundation from subsequent hurricanes, especially in the short term. This would likely remove all of the emergent sand from the marsh platforms again, exposing the muddy fragments to further degradation. Airborne lidar surveys showed that the inundated Chandeleurs lost 82 percent of their surface area, and their Gulf-front shores eroded landward an average of $\sim 250 \mathrm{~m}$ ( $\sim 820 \mathrm{ft})$. Combined with subsidence of the Mississippi Delta, rapid local RSLR has conditioned the coast for future extreme-storm changes. Should global sea-level rise accelerate in the future as predicted, barrier islands and sandy shorelines worldwide may respond similarly after being inundated during tropical storms.

Besides inundation, extreme storms striking the Gulf Coast region have caused several different morphological responses and have resulted in a large range of washover-penetration distances. Morton and Sallenger (2003) report that post-storm erosional responses included dune scarps, channel incisions, and washouts, whereas depositional responses included perched fans, washover terraces, and sheetwash lineations (fig. 49). The largest of these features are washover penetrations, products of shallow water, confined flow, and high-wind stress, ranging in length from approximately $\sim 100$ to $1,000 \mathrm{~m}$ ( $\sim 328$ to $3,280 \mathrm{ft}$ ) with estimated erosional sediment volumes ranging from $\sim 10$ to $225 \mathrm{~m}^{3} / \mathrm{m}$ ( $\sim 13$ to 294 $\mathrm{yd}^{3} / \mathrm{yd}$ ) of beach. Unusual styles of morphological response (sheetwash lineations and incised channels) and maximum washover-penetration distances are closely correlated. Regional morphological responses and washover-penetration distances are controlled primarily by storm size, intensity, and approach direction. Transport and deposition of washover sediments across barrier islands and into the adjacent lagoon are common processes along the Gulf. These morphologic responses have a potential direct impact to constructed sandy beaches.

The washover process and associated deposits occur along the shores that are overtopped and inundated by waves and storm surge, causing the shoreline to retreat landward. The deposits form washover fans and terraces parallel to the wetland shores of the Gulf of Mexico or to shores of large embayments. Typical widths of washover deposits are 5 to $20 \mathrm{~m}$ ( 16.4 to $65.6 \mathrm{ft})$ along the embayment shores, whereas 20- to $150-\mathrm{m}$ (65.6- to 492-ft) widths have been reported along the Gulf shore for extreme storms (Morgan and others, 1958; Ritchie and Penland, 1988; Nyman and others, 1995; Faulkner and others, 2007). Thick washover deposits can raise the land elevation above the zone of normal inundation. Consequently, an overwashed former wetland near the shoreline can be colonized by non-marsh vegetation and be converted to an upland habitat (Courtemanche and others, 1999). As an example, in 1992, Hurricane Andrew buried marsh areas with overwash sediments; 2 years later, as much as 40 percent of these barren areas had been revegetated (Morton and Barras, 2011).

A. Dune Erosion

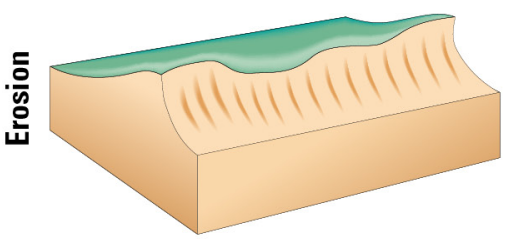

D. Washover Terrace

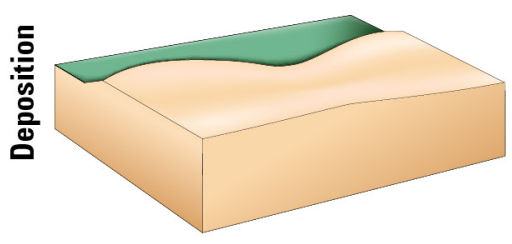

B.Channel Incision

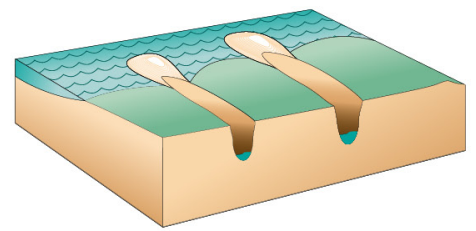

E. Perched Fans

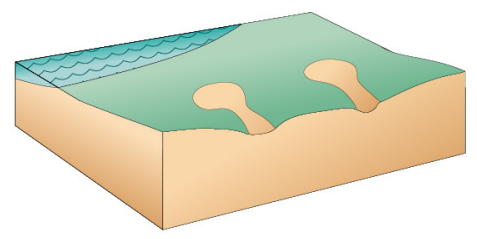

C. Washout

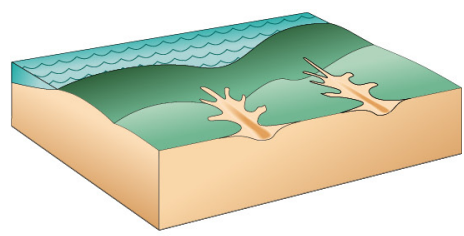

F. Sheetwash Lineations

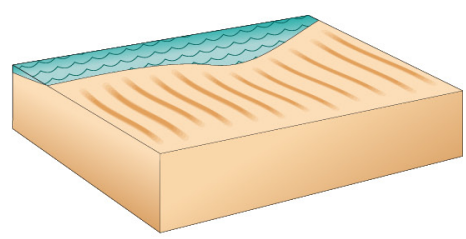

Sand

Vegetation

Water

Figure 49. Types of erosional and depositional features produced by extreme storms include (A) dune erosion, (B) channel incision, (C) washout, (D) washover terrace, (E) perched fan, (F) sheetwash lineations (Morton and Sallenger, 2003). Whereas these six processes can cause shoreline deposition and erosion (Morton and Sallenger, 2003), perhaps the most frequently reported hurricane morphological impacts are the widespread shoreline deposits that result from the inland transport of sand and shell by storm overwash. See Sallenger scale Impact Level 3 (fig. 45). 


\title{
THEME 4: Barataria Bay Tidal-Inlet Management Considerations
}

\author{
Authors: Howes, N.C. ${ }^{*}$, Z.J. Hughes¹, D.M. FitzGerald ${ }^{1}$, I.Y. Georgiou², J.L. Kindinger ${ }^{3}$, N.A. Buster ${ }^{3}$ \\ ${ }^{1}$ Department of Earth and Environment, Boston University, Boston, Massachusetts \\ ${ }^{2}$ Department of Earth and Environmental Sciences, University of New Orleans, New Orleans, Louisiana \\ ${ }^{3}$ St. Petersburg Coastal and Marine Center, USGS, St. Petersburg, Florida \\ * Clastics Research, Shell International Exploration and Production, Houston, Texas
}

Bathymetric data collected during the BICM project were particularly useful in documenting the evolution of tidal-inlet morphology and hydrodynamics, as well as the redistribution of sediment reservoirs that result from the high rate of RSLR. Tidal inlets play an integral role in the response of the Louisiana coast to RSLR, and this study identified previously unrecognized feedback among inlet morphology, back-barrier tidal range, and tidal prism. This will be discussed with a focus on the Barataria Basin barrier island system, beginning with an overview of the morphological and hydrodynamic response of the Barataria Basin to RSLR then focusing specifically on the role of tidal inlets. In Barataria Basin, high rates of RSLR ( 1 cm/yr) caused substantial wetland loss between 1956 and 2004 (more than $775 \mathrm{~km}^{2}$, about $300 \mathrm{mi}^{2}$; Barras, 2006) and a concomitant increase in area of open water within Barataria Bay. The increase in open water within the bay resulted in a larger tidal prism and forced a greater tidal discharge through the inlets. Inlet cross-sectional areas enlarged over time to accommodate the enlarging prism and as inlet area increased, the data indicate that backbarrier tidal range increased and augmented the tidal prism. This feedback between inlet morphology and back-barrier tidal range had not been recognized before and illustrates the dynamic, interconnected nature of the processes associated with Barataria Bay (or any bay) as a whole. These findings have implications for restoration practices and for identifying the importance of constructing land in the lower basin in a proximal location to the tidal inlets. This discussion utilizes BICM data as well as additional historical bathymetric data and hydrodynamic data and summarizes the master's thesis of Howes (2009).

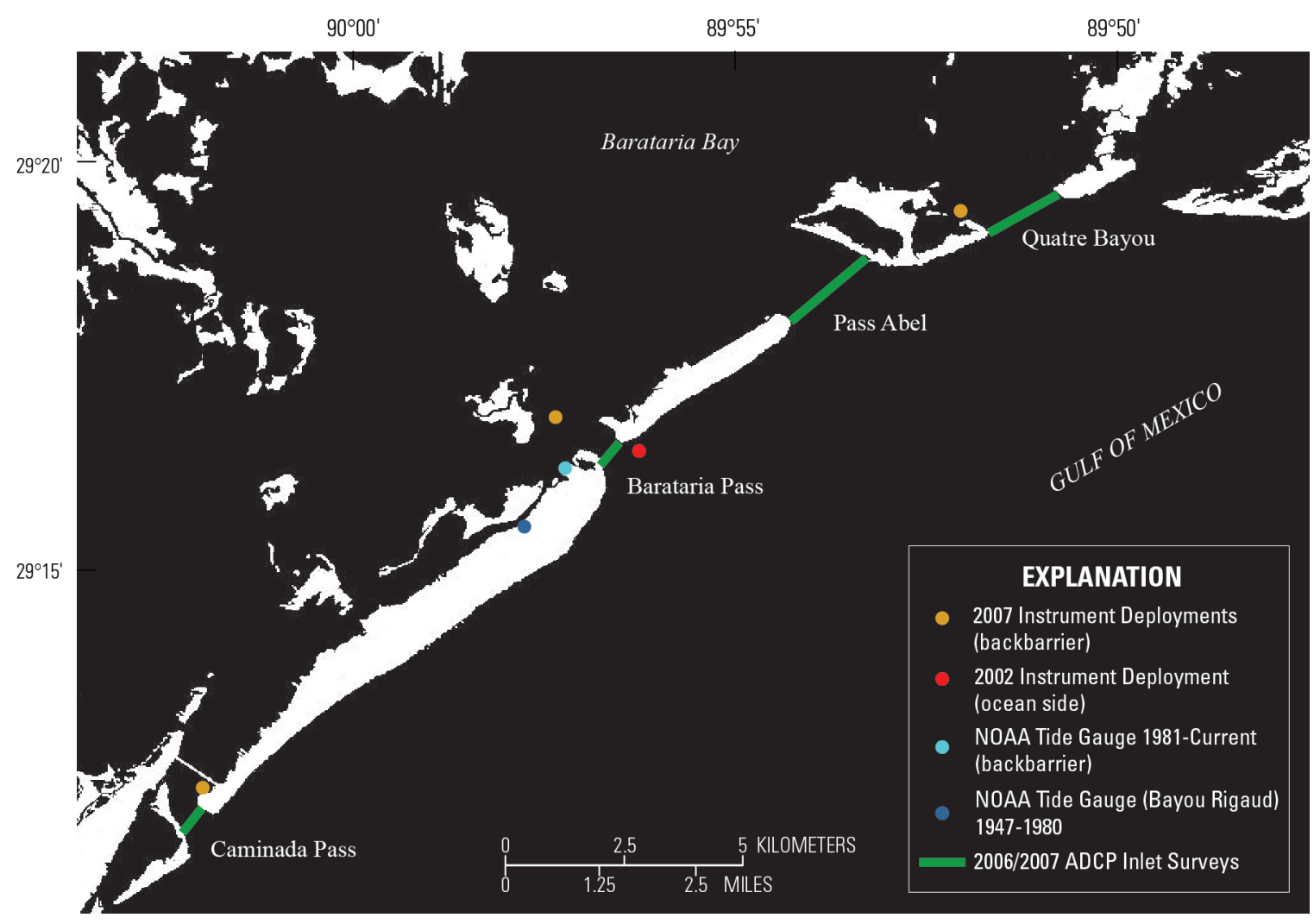

Figure 50. Hydrodynamic instrument deployment locations and acoustic Doppler current profiler (ADCP) survey tracklines (Howes, 2009). 


\section{Methods}

To establish the response of tidal inlet morphology and hydrodynamics to RLSR over the past $\sim 100$ years, modern conditions were measured and compared with past conditions using historical datasets and records. Modern inlet morphology was measured with single-beam bathymetric surveys, which were conducted in 2006 and repeated in 2007, and included the four Barataria Bay inlets (Barataria Pass, Quatre Bayou, Pass Abel, and Caminada Pass) (fig. 50). To establish a comparison with past conditions, a historical record of inlet morphology was obtained from the regional-scale bathymetric changes in Barataria documented in BICM Volume 3 using data from surveys in the 1890s, 1930s, 1980s, and 2006. Because surveys in the 1890s, 1930s, and 1980s spanned multiple years, the midpoint dates were chosen for reference (1888, 1935, and 1988, respectively) (Miner, Kulp, FitzGerald, and Georgiou, 2009). To constrain the modern hydrodynamics, acoustic-doppler current profilers (ADCP) were used to profile the tidal flow/exchange within the inlets, and four current meters were placed landward of the surveyed inlets to measure the tidal water-surface elevation at the time of the surveys. Modern tidal range and the propagation of the tidal wave through Barataria Bay were determined from 11 USGS tide-gage stations located within the back-barrier. Historical data on tidal range were obtained from the Grand Isle tide-gage for the period 1951 to 2006, and additional historical hydrodynamic data were used from a long-term current meter deployment on the Gulf side of Barataria Pass in 2002. Unfortunately, there was no historical record of inlet hydraulics. In order to address this gap, modern field data were used to calibrate a one-dimensional (1-D) hydrodynamic model of inlet hydraulics focused on Barataria Pass. Once the model was calibrated, it was used to hindcast historical inlet hydraulics as well as back-barrier tidal range based on past bathymetric configurations of Barataria Pass obtained from the 1890s, 1930s, 1980, and 2006 surveys.

\section{Tidal-Inlet Morphological and Hydrodynamic Evolution}

The tidal inlet cross sections in Barataria Basin display variable morphologies. However, two distinct categories of inlets were apparent: (1) inlets with a symmetrical cross section, and (2) inlets with a distinctly asymmetrical cross section. Barataria Pass is symmetric in cross section, whereas Quatre Bayou Pass, Pass Abel, and Caminada Pass inlets are each asymmetric with a shallow subaqueous platform along their eastern margin and a thalweg (deepest portion of the inlet) occurring consistently on the western margin (fig. 51a). The asymmetric inlets generally are wider than their symmetric counterpart, and among the asymmetric inlets, the Caminada platform width is significantly less than the platform widths at Pass Abel and Quatre Bayou.

Historically, cross-sectional areas of the Barataria Basin inlets have increased in response to wetland loss and the ensuing larger tidal prism. Between 1888 and 2006, the cumulative inlet area increased by a factor of three, from $6,400 \mathrm{~m}^{2}$ to $20,890 \mathrm{~m}^{2}\left(68,889 \mathrm{ft}^{2}\right.$ to $\left.224,858 \mathrm{ft}^{2}\right)$ (Howes, 2009). However, as the inlet cross-sectional areas increased to accommodate the greater tidal prism, the two categories of inlet symmetries evolved very differently.

The cross-sectional area of Barataria Pass increased primarily by way of deepening of the inlet (fig. 51a). This process can be described by the hydraulic radius, which is defined as the ratio of inlet area to inlet perimeter and is a proxy for the mean flow depth. As the cross-sectional area increased, so did the hydraulic radius, following a linear trend (indicating deepening) (fig. 51b). In contrast, the increase in area of Quatre Bayou, Caminada Pass, and Pass Abel primarily was associated with widening and the erosion of the channel edge, producing a wide shallow platform and an asymmetric inlet. As the cross-sectional areas of these inlets increased, the hydraulic radii (or mean flow depth) remained nearly constant (fig. 51b). This response demonstrates that morphology of Quatre Bayou, Pass Abel, and Caminada evolved along a very different trajectory than that of Barataria Pass. The difference in cross-sectional morphology is significant in terms of inlet hydraulics. If all other variables remain constant, a larger hydraulic radius in a channel results in greater channel efficiency and less energy lost to friction between the water and the sediment bed. Thus increases in channel area at Barataria Pass have resulted in greater inlet efficiency in contrast to the Quatre Bayou, Pass Abel, and Caminada Pass, where inlet areas have increased with the widening platform region, but not with the same increase in inlet efficiency. This effect is apparent in the hydrodynamic data. For a given tide, Barataria Pass is able to convey twice the discharge of Quatre Bayou, despite comparable cross-sectional areas, a fact that can be attributed to the difference in hydraulic radius and efficiency. An increase in hydraulic radius, with other factors being constant, also reduces tidal wave attenuation and results in a larger tidal range in the back-barrier environments (see Tidal-Range Evolution).

In addition to understanding the overall cross-sectional response of the inlet system to wetland loss and larger tidal prisms, it is also important to determine how the tidal discharge and prism are distributed between the inlets. The peak discharge at the inlets varies directly with tidal range, such that the greatest discharge occurs during tropic tides (fig. 52). Tidal discharge is distributed unevenly between the inlets. The discharge at Barataria Pass is more than twice the 

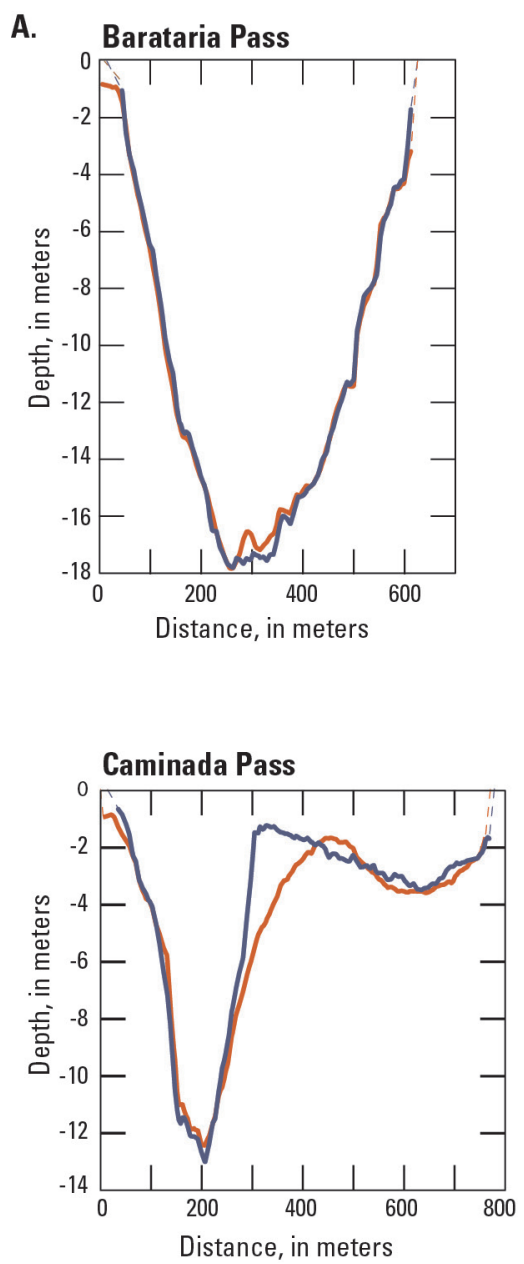
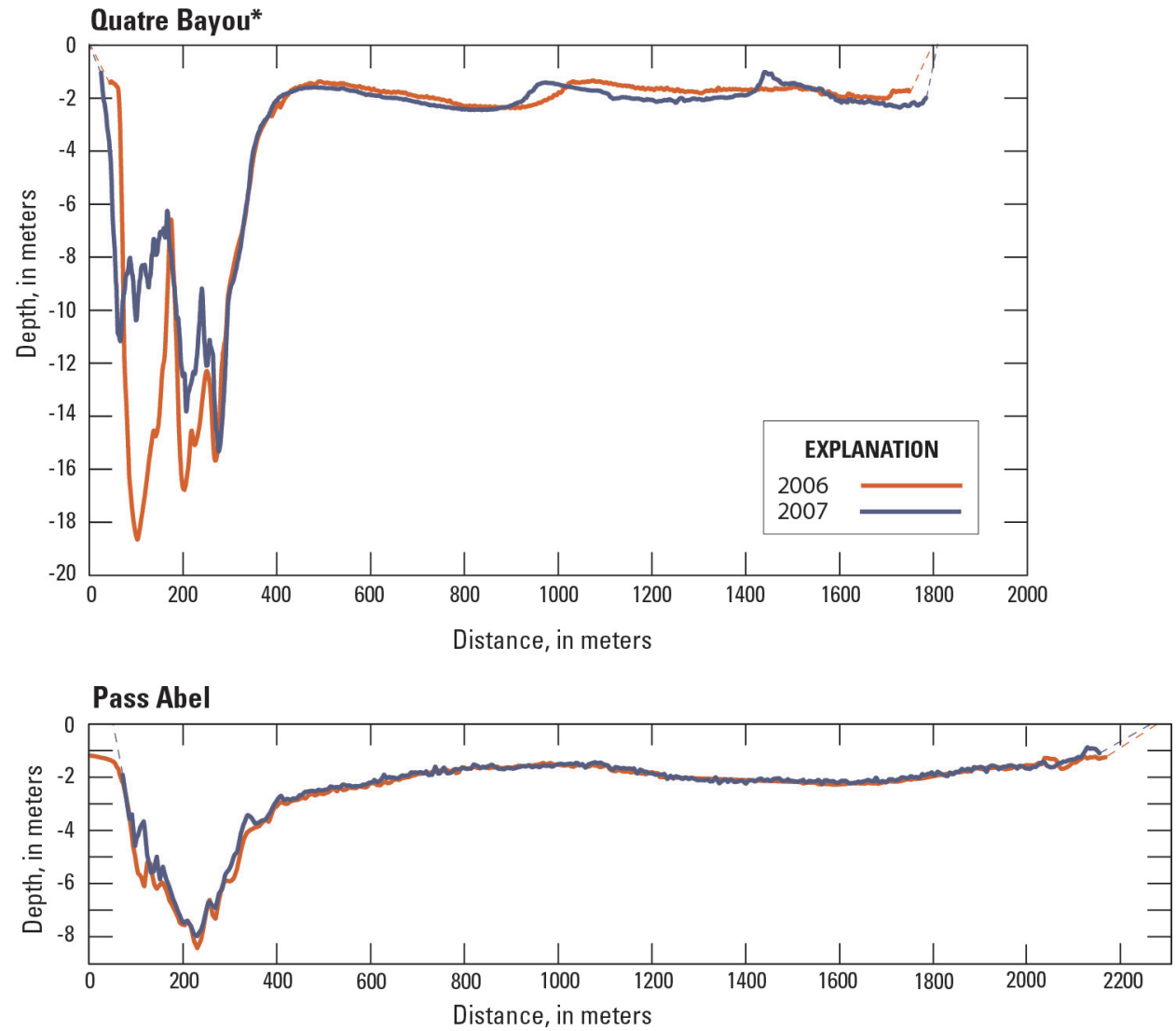

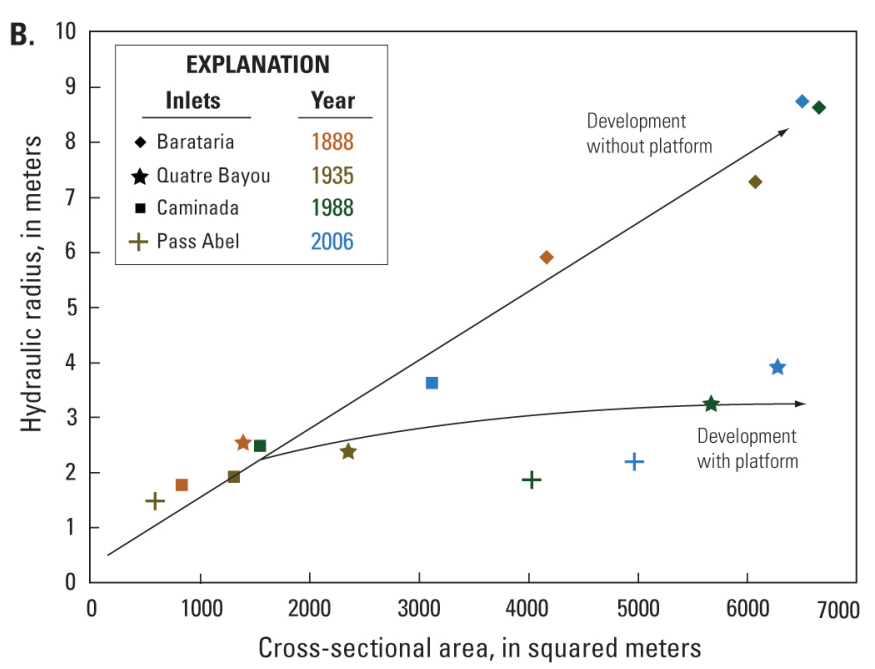

Figure 51. (A) High resolution tidal inlet cross sections from single beam soundings (Howes, 2009) $\left({ }^{*}\right.$ denotes transects across the inlets were taken along the same line each, with the exception of Quatre Bayou, where they were offset by 50 meters). (B) Barataria Pass shows an increase in inlet hydraulic radius with increased cross-sectional area compared to the other three passes. It is also the only inlet that did not develop an inlet platform even with increased cross-sectional area (Howes, 2009). 


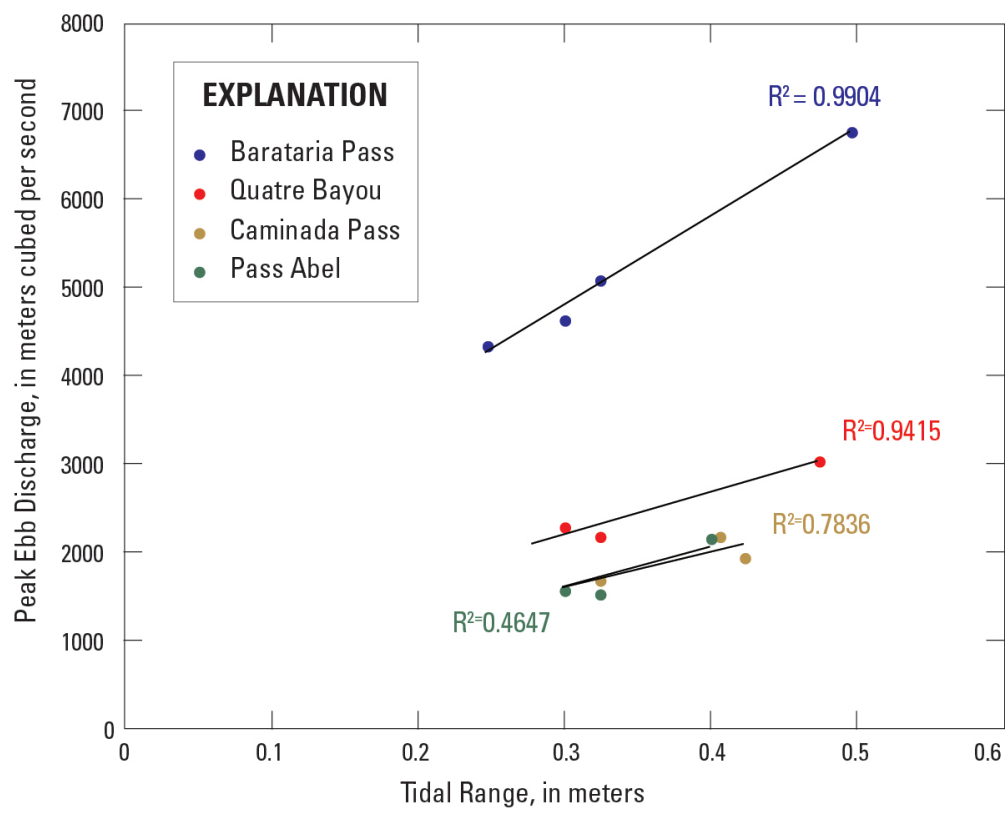

Figure 52. Graph showing the relation between peak ebb discharge and tidal range for the four inlets (Barataria Pass, Quatre Bayou, Caminada Pass, and Pass Abel). The data represent a synthesis of ADCP and BICM data collected in 2002, 2006, and 2009 (Howes, 2009).

magnitude of any other inlet for a given tide. As the tidal range increases over a tropic-equatorial cycle, the peak discharge at Barataria Pass increases at a faster rate than at the other inlets (fig. 52), resulting in its capture of a greater proportion of flow relative to the other inlets during the largest tides. Barataria is clearly the dominant inlet in the system and is thus the focus of the 1-D model. Quatre Bayou has the second largest discharge of the inlets, whereas the discharges at Caminada Pass and Pass Abel are roughly equal in magnitude and are the least significant of the group. In order to calculate tidal prism, discharge was integrated over a single flood or ebb cycle to determine the volume of water (prism) exchanged through the inlets. On the basis of these calculations, Barataria Pass exchanges nearly 50 percent of the bay's tidal prism. These discharge data were used to construct and validate a 1-D model of inlet hydraulics. In general, the model is in close agreement with the field data but with a slight tendency to overpredict discharge. This model is used in a later section to hindcast bay tidal range.

Tidal currents in each of the four inlets exceed 1 meter per second $(\mathrm{m} / \mathrm{s})(3.28$ feet per second $[\mathrm{ft} / \mathrm{s}])$ at peak ebb discharge (Howes, 2009). The greatest currents at Barataria Pass are concentrated along the eastern portion of the inlet (average current velocity exceeds $1.25 \mathrm{~m} / \mathrm{s}, 4.1 \mathrm{ft} / \mathrm{s}$ ). In the other three inlets - Caminada Pass, Pass Abel, and Quatre Bayou-maximum currents are entirely confined to the western thalwegs, and the depth-averaged currents in the channels are generally $\sim 1 \mathrm{~m} / \mathrm{s}(3.28 \mathrm{ft} / \mathrm{s})$, locally exceeding $1.5 \mathrm{~m} / \mathrm{s}$. The shallow platforms in these three inlets account for $\sim 60$ percent of the cross-sectional area, but only 30-35 percent of the total discharge at peak flow. Thus, the majority of the discharge is confined to the inlet thalwegs. The inlets to Barataria Bay are ebb-dominant; thus, sediments eroded from the bay or adjacent to the inlets are redistributed offshore and sequestered in ebb-tidal deltas. The ebb dominance results from the interaction of the diurnal and semi-diurnal tidal constituents (for more information on this process see, van Maren, 2004). The following section describes the morphological response of each inlet in greater detail.

\section{Barataria Pass}

A review of historical bathymetry at Barataria Pass indicated that the inlet channel has not migrated laterally and has occupied the same footprint since at least 1888 (fig. 53) (Howes, 2009). In 1958, a navigational jetty was constructed on the western side of the inlet. The jetty trapped the littoral transport of sediment, causing Grand Isle to prograde seaward while all other regions, such as Grand Terre, retreated. Progradation and erosion of the shoreline resulted in a 15-degree counter-clockwise rotation of the inlet channel between 1888 and 2006 (Howes, 2009). In addition to channel rotation, Barataria Pass has undergone other geomorphic changes: (1) the inlet has lengthened, (2) the cross-sectional area of the inlet throat (defined as the area between the islands) has increased, and (3) the hydraulic radius has increased (Howes, 2009) (fig. 54).

In his analysis of Barataria Pass, Howes (2009) used the 5-m contour to approximate the location of the inlet channel and the 10-m contour to approximate the inlet throat/thalweg (the deepest portion of the inlet) (fig. 54a). The inlet 


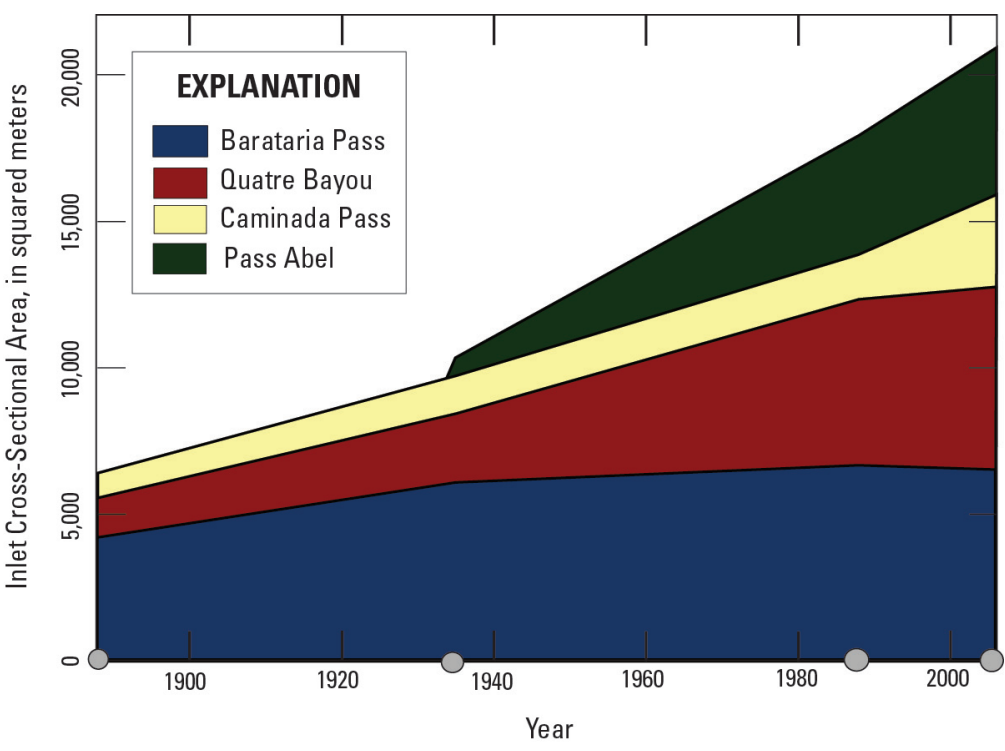

Figure 53. Graph showing inlet cross-sectional area since 1888 . The gray points along the $x$-axis represent the bathymetric-survey dates. The change between the data points is a linear interpolation (Howes, 2009).
A.
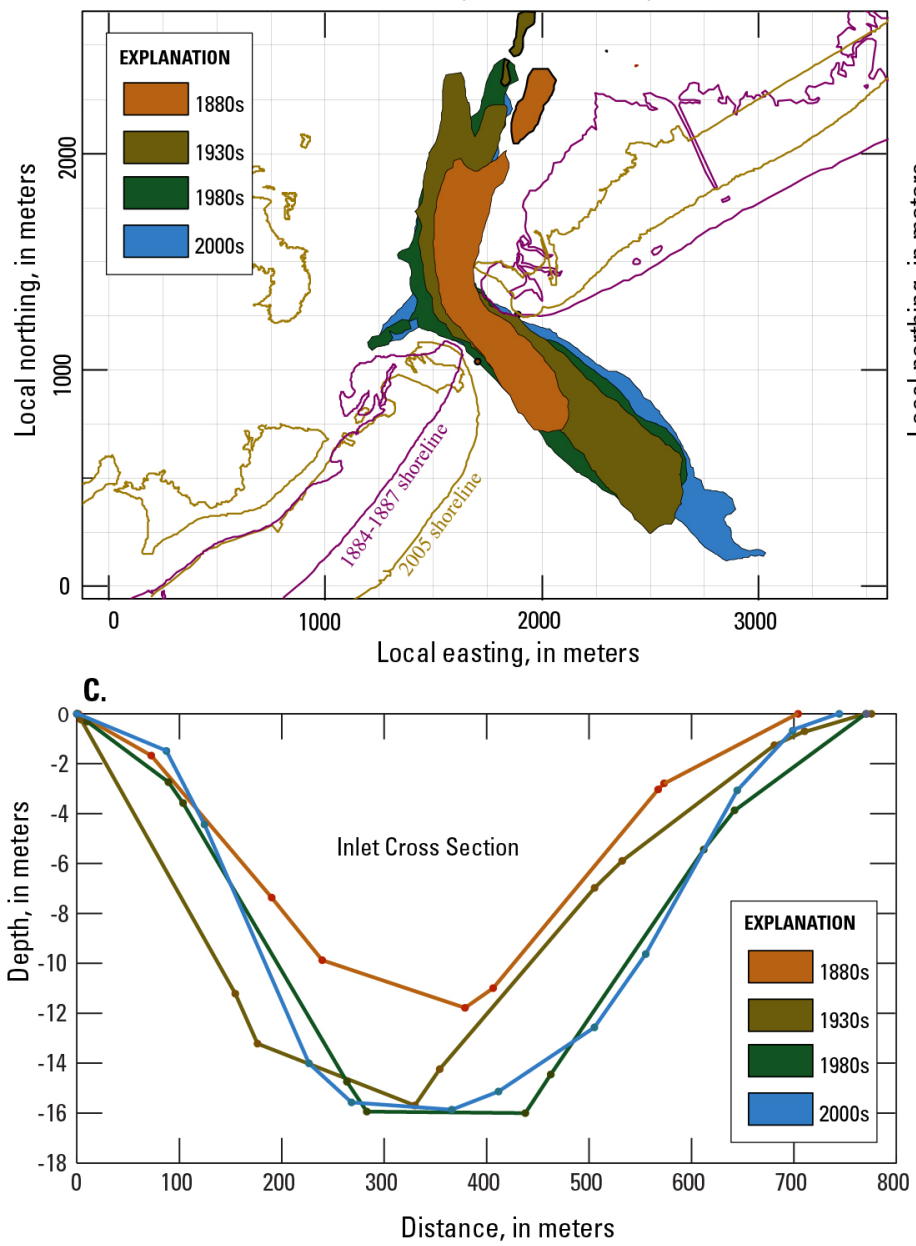

Barataria Pass

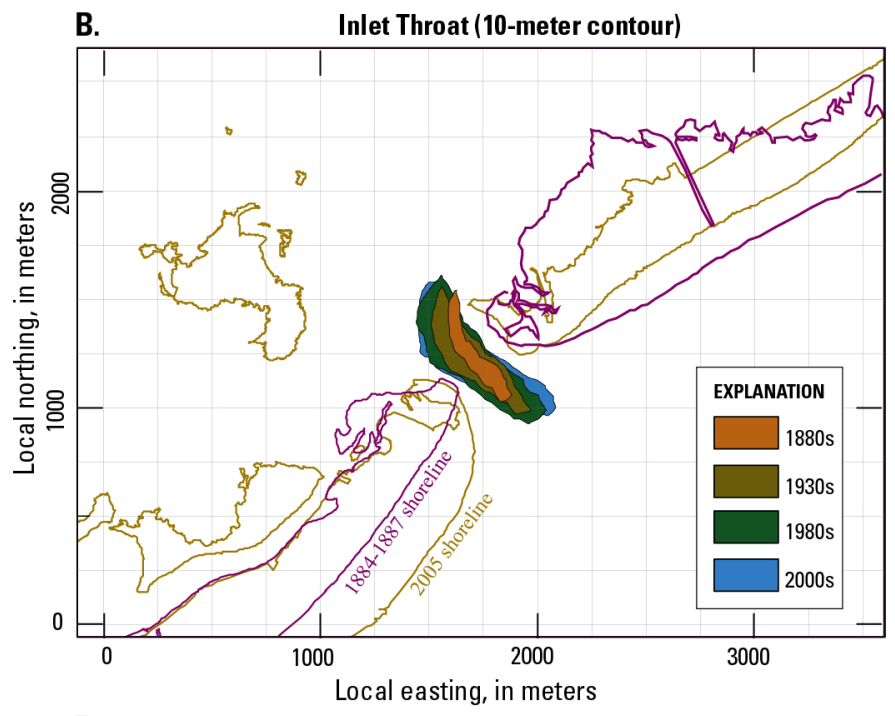

D.

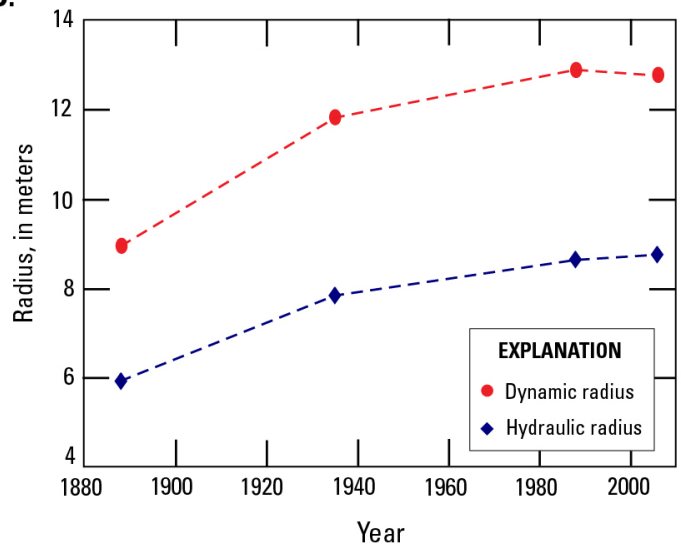

Figure 54. The morphological evolution of Barataria Pass, including $(A)$ the extension of the inlet channel as defined by the $5 \mathrm{~m}$ contour, (B) the inlet throat defined as greater than $10 \mathrm{~m}$ deep, (C) cross sections across the inlet throat, and (D) the change in hydraulic and dynamic radius (dynamic radius is a measure that weights the depth to the power of 5/3); the dynamic-radius measure shows the same general trend as hydraulic radius (Howes, 2009). 
channel extends beyond the barrier islands into the back barrier and seaward onto the ebb-tidal delta. The inlet channel has increased in cross-sectional area in response to tidal-prism changes within Barataria Bay. As the tidal prism increases, a greater volume of flow converges on the inlet channel, and velocities increase at the channel entrance, resulting in erosion and elongation of the channel. The inlet throat occurs in the confined portion between the barrier islands and experiences the highest tidal velocities; the length of the inlet throat has remained more stable than that of the inlet channel (fig. 54b). The greatest rate of change in cross-sectional area of the inlet throat occurred during the period from 1888 to 1935. After 1935, the rates of increase decelerated, and the channel area seemed to stabilize between 1988 and 2006 (fig. 53). Although the cross-sectional area of Barataria Pass stabilized in 1988, the cross-sectional area of the other inlets in the system has continued to increase.

\section{Quatre Bayou Pass}

Quatre Bayou Pass is the second largest tidal conduit within the Barataria system (Howes, 2009) (fig. 52). The inlet throat has significantly deepened over time and has migrated landward as the shoreline retreated historically (Penland and others, 2005; Miner, Kulp, FitzGerald, Flocks, and Weathers, 2009) (fig. 55). The shoreline and the inlet have undergone more than $1 \mathrm{~km}$ of shoreline retreat since 1884 at an average rate of $-11.6 \mathrm{~m} / \mathrm{yr}(-38 \mathrm{ft} / \mathrm{yr})$ (Penland and

\section{Quatre Bayou}
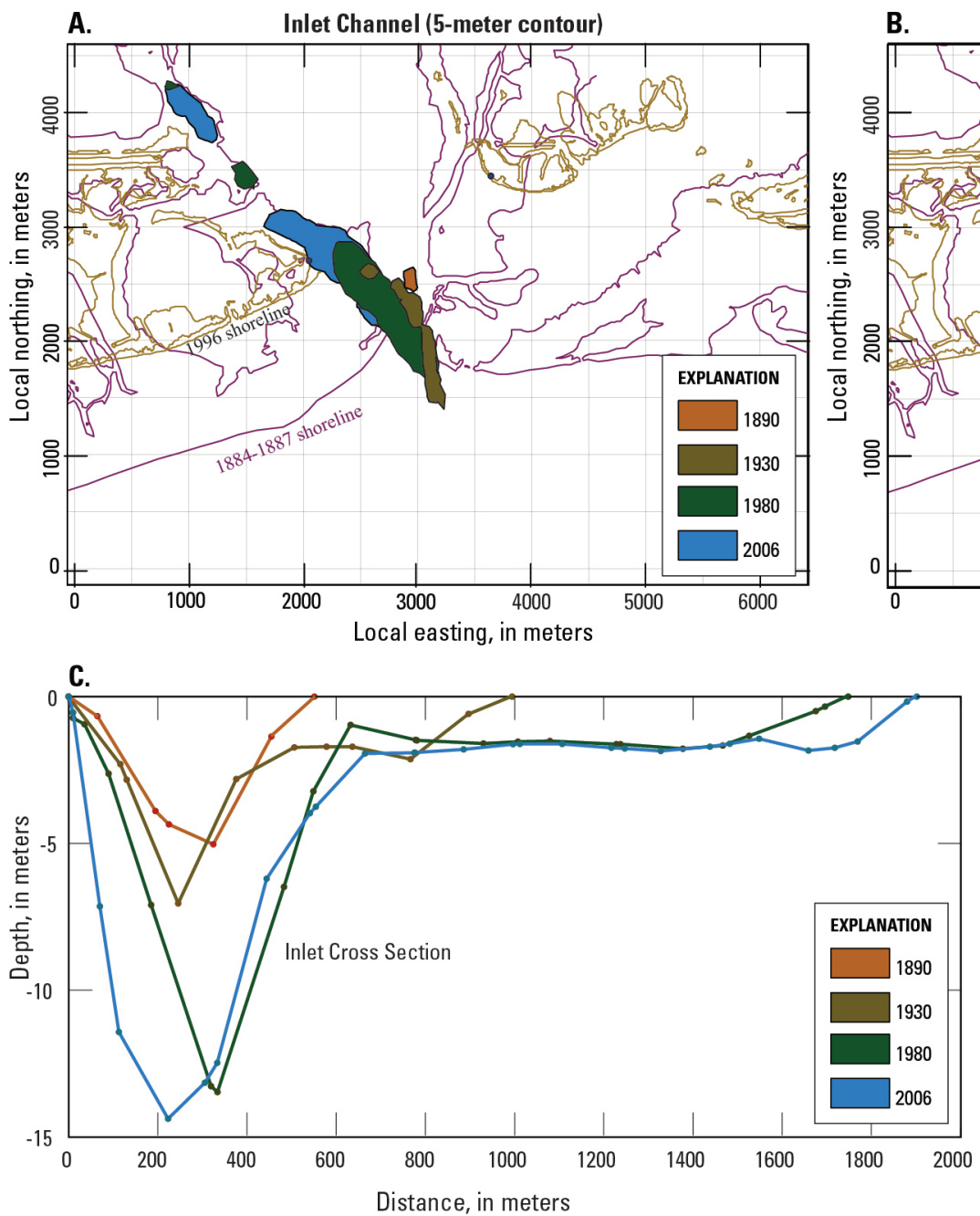

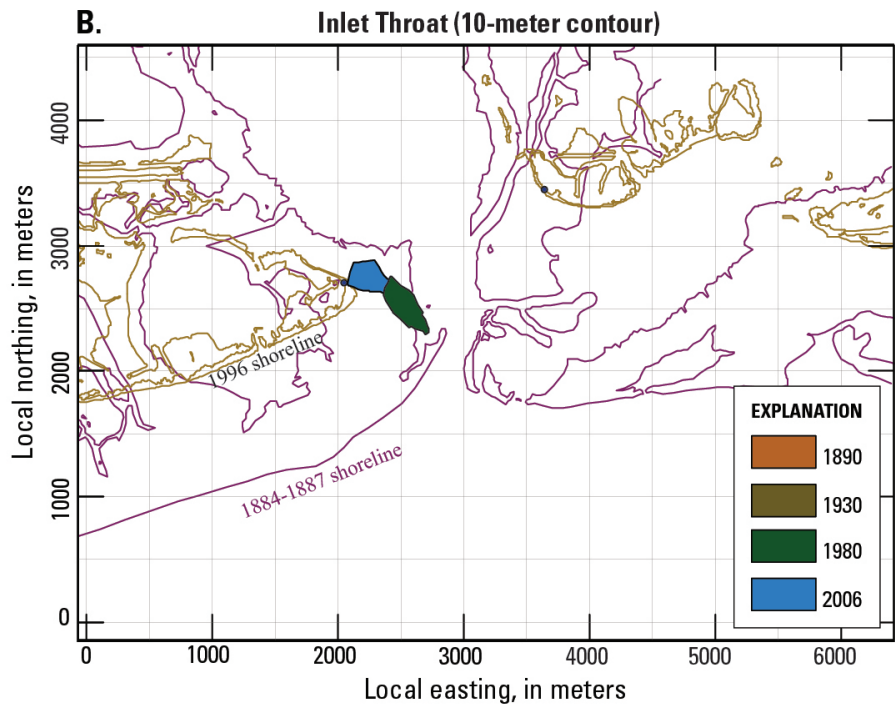

D.

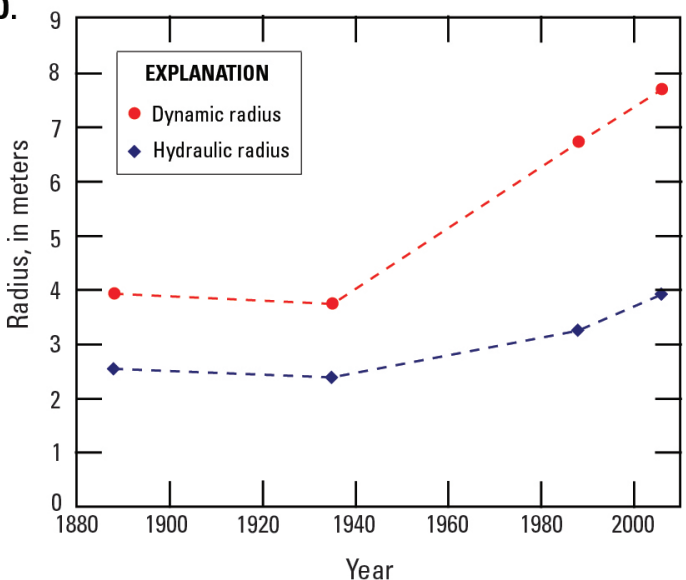

Figure 55. Morphological evolution at Quatre Bayou Pass, including (A) the extension of the inlet channel, (B) the inlet throat defined as greater than $10 \mathrm{~m}(32.8 \mathrm{ft})$ deep, (C) cross sections across the inlet throat, and (D) the change in hydraulic and dynamic radius. 
others, 2005). As the pass migrated landward, it eroded into a complex sedimentary sequence that may consist of a relict distributary channel (Levin, 1995), resulting in an extremely irregular bathymetry within the modern inlet channel. The rates of shoreline retreat are high in the vicinity of Quatre Bayou inlet for two reasons: (1) the inlet lacks a proximal sediment source such as the Caminada headland to the west, and (2) a portion of the longshore drift is trapped in the updrift ebb-tidal delta at Barataria Pass (List and others, 1997).

The 10-m contour within Quatre Bayou did not exist at the time of the 1935 surveys; the contour developed as the inlet deepened between 1935 and 1988 (fig. 55b). Howes (2009) reported that the opening at Quatre Bayou widened since the 1888 survey and that the opening consists of two distinct geomorphic features: (1) a channel thalweg on the west bank, and (2) an extensive shallow shelf on the eastern margin that occupies most of the inlet width (fig. 55c). The majority of the tidal flow (between 65 and 75 percent) is confined within the channel. The shelf has a nearly constant depth over its width, and Howes (2009) suggested that a combination of sediment starvation and wave-current processes eroded a veneer of unconsolidated barrier sediments adjacent to the inlet, leaving the platform morphology. During a sustained ebb flow, tidal currents over this platform are between 0.35 and $0.50 \mathrm{~m} / \mathrm{s}(1.45$ and $1.64 \mathrm{ft} / \mathrm{s})$ with velocities sufficient to cause erosion of sands and abrasion of muds. Georgiou and others (2005) showed that storm waves $(>1-2 \mathrm{~m},>3.28-6.56 \mathrm{ft})$ may also play a role in the erosion of this platform. The increase in hydraulic radius in Quatre Bayou is much more muted than the increase in Barataria Pass when measured over the same time period, since much of the increase in cross-sectional area has been due to the expansion and widening of the shallow subaqueous platform (Howes, 2009).

A.
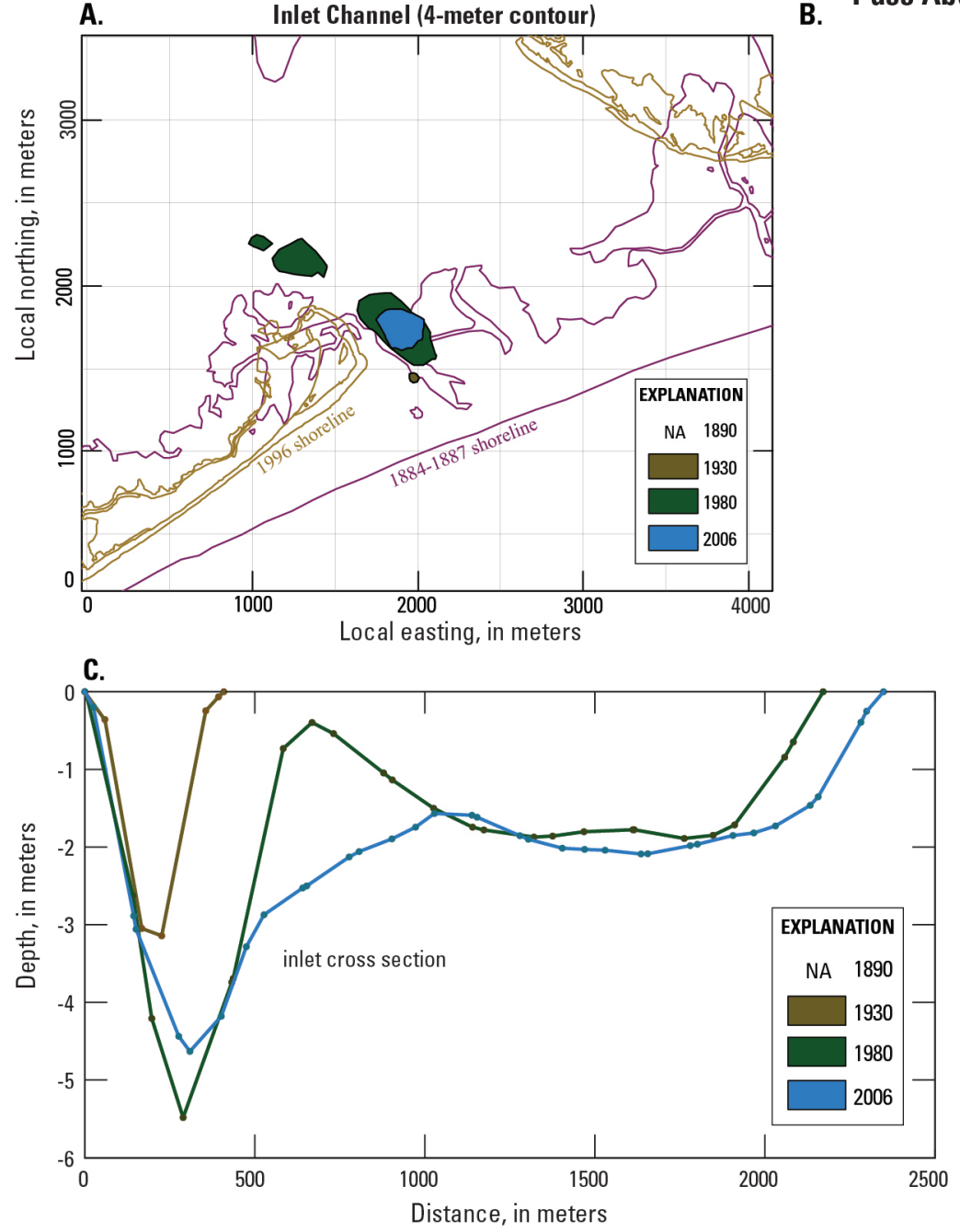

B.

Pass Abel
Inlet Throat (10-meter contour)

NOT AVAILABLE
D.

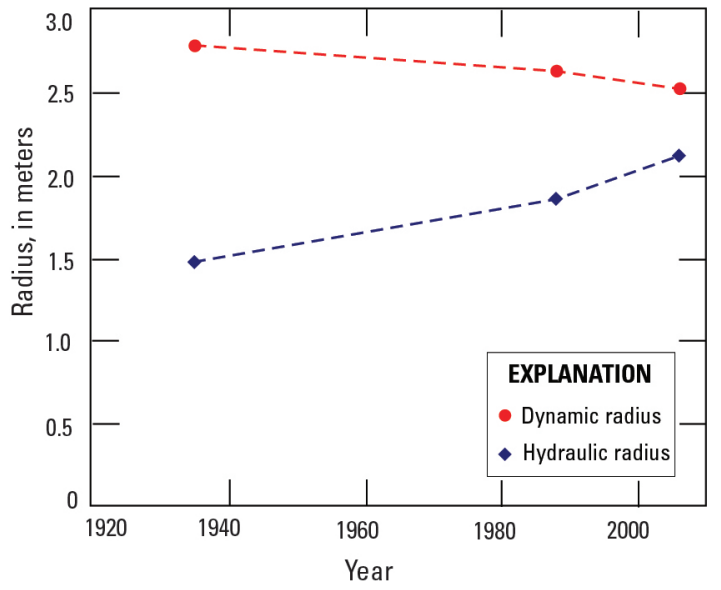

Figure 56. Morphological evolution at Pass Abel, including (A) the extension of the inlet channel, (B) there is no panel for $B$ because the inlet throat was defined as greater than $10 \mathrm{~m}$, and this inlet did not achieve that depth, (C) cross sections across the inlet throat, and (D) the change in hydraulic and dynamic radius. 


\section{Pass Abel}

The morphological evolution of Pass Abel is similar to that of Quatre Bayou. Pass Abel is the widest inlet in the chain (2.2 km, $1.4 \mathrm{mi}$ ) (fig. 56). The thalweg is located along the western margin, abutting a wide subaqueous platform on the eastern side; a morphology that is remarkably similar to that of Quatre Bayou (fig. 55b). Pass Abel formed between the 1888 and 1935 surveys. Shamban (1985) reported that it was present on the 1841 maps, although this initial opening was ephemeral and had apparently closed by 1888 before reopening permanently sometime after that (fig. 56a). FitzGerald and others (2004) hypothesized that the inlet reopened and remained stable in response to the increased bay tidal prism due to ongoing wetland loss. The proximity of Pass Abel to Barataria Pass allows it to capture a portion of Barataria's tidal prism, which likely has contributed to the decreasing rate of change in inlet area at Barataria Pass after 1935 (Howes, 2009).
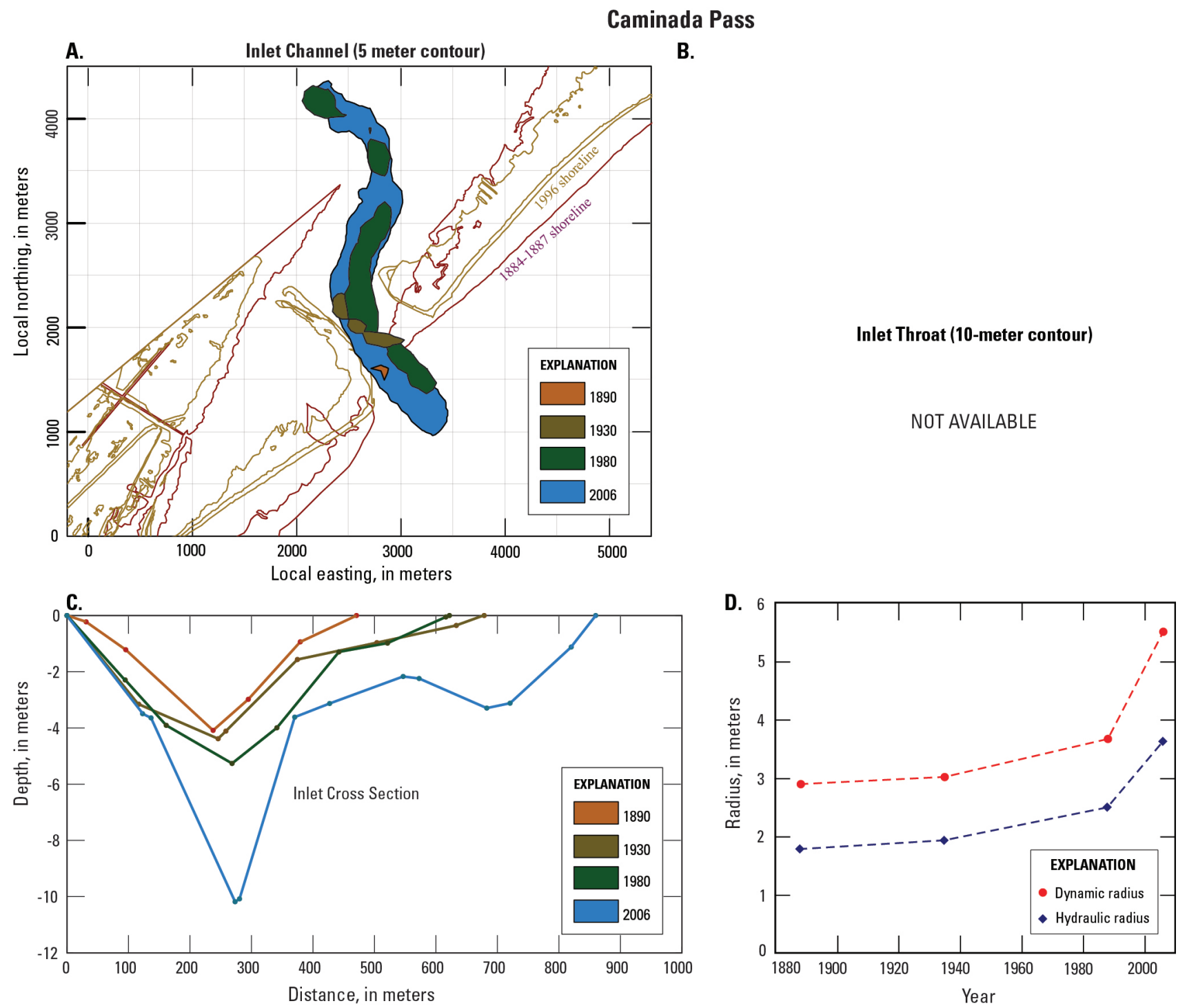

Figure 57. Morphologic evolution at Caminada Pass, including (A) the extension of the inlet channel, (B) there is no panel for $B$ because the inlet throat was defined as greater than $10 \mathrm{~m}$, and this inlet did not achieve that depth, (C) cross sections across the inlet throat, and (D) the change in hydraulic and dynamic radius. 
BICM Program Summary Report: Data and Analyses 2006 through 2010

\section{Caminada Pass}

The channel thalweg at Caminada Pass is also situated on the western margin of the inlet. A shallow platform extends to the eastern margin (fig. 57a and b), where the shore has been stabilized by riprap (Howes, 2009). In this area, the shoreline retreat rate is slower than in other areas of Barataria Basin, primarily due to the close proximity of Caminada Pass to the Caminada Headland, which is the primary sediment source for the shoreline (Howes, 2009). Between 1988 and 2006, the inlet grew substantially in cross-sectional area, channel-platform area, and hydraulic radius (fig. 57c).

Shoaling in Caminada Pass between 2006 and 2007 (Howes, 2009) was apparently a post-storm response to the Hurricane Katrina landfall. During passage of the hurricane, the wind pattern forced water into the basin (which was elevated due to the storm surge) southwest toward Caminada Pass (Resio and Westerink, 2008). Elevated water levels and storm-surge return flows produced ebb currents through the inlet in excess of $3.3 \mathrm{~m} / \mathrm{s}(10.8 \mathrm{ft} / \mathrm{s})$ (Carter, 2008). Howes (2009) suggested that these storm-induced, ebb-dominated tidal currents eroded sand from the channel margins, resulting in a temporary widening of the inlet, and the inlet, cross-sectional area was, thus, out of equilibrium with normal tidal flows. Subsequent shoaling of the inlet restored it to pre-storm configuration (a process captured by the 2006-2007 repeat survey).

\section{Tidal-Range Evolution}

A long-term tide- gage dataset provides a historical record of tidal range in Barataria Bay. The record is a composite of two tide stations: the older Bayou Rigaud station and a modern Grand Isle station. Until 1979, the Bayou Rigaud station (NOAA ID: 8761720) was situated approximately $2.0 \mathrm{~km}$ (1.24 mi) west of Barataria Pass. In 1979, the modern Grand Isle station (876172) was installed in close proximity to Barataria Pass. The timing of station relocation does not correspond to the break in slope in the tide record around 1970; thus, the relocation is not responsible for the
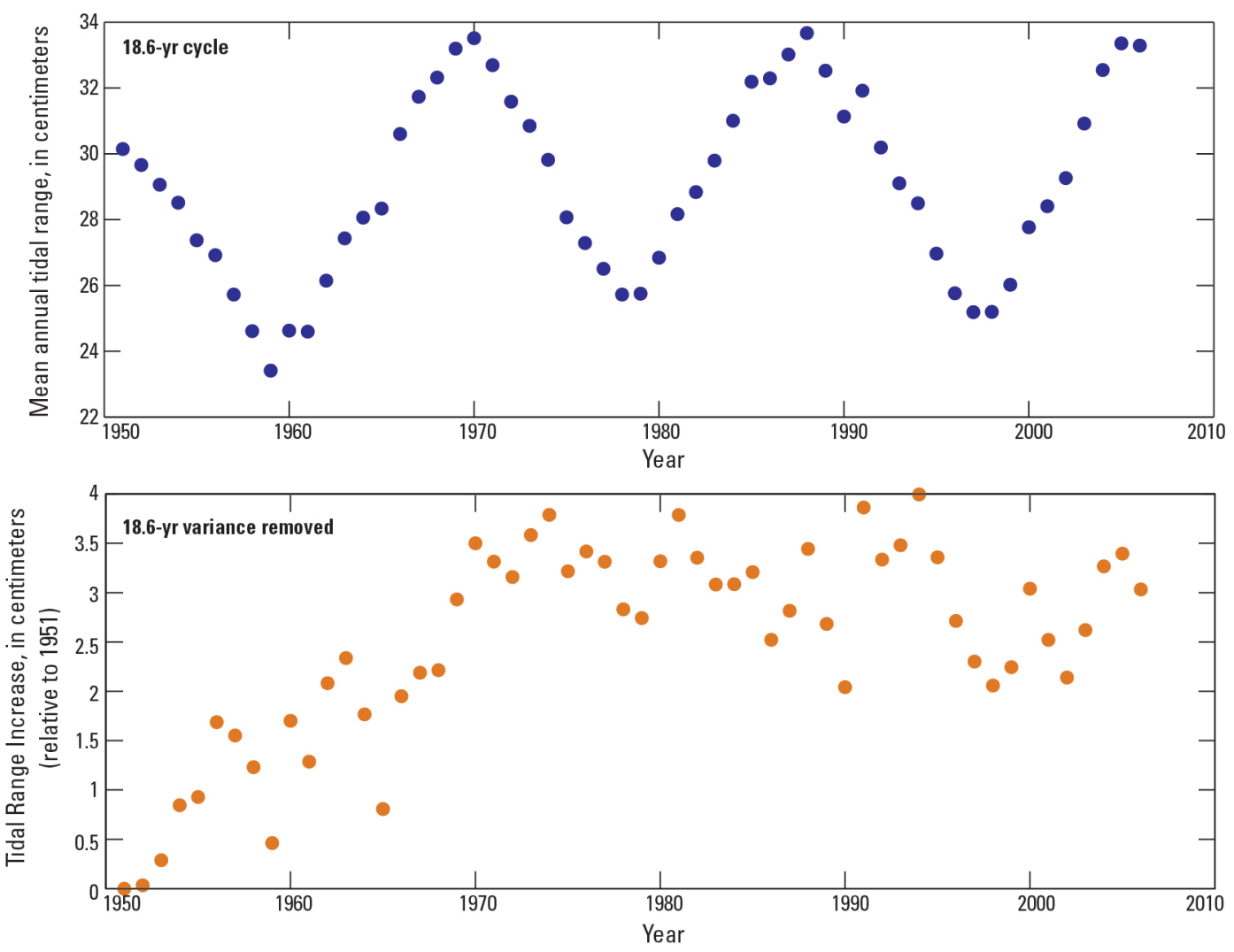

Figure 58. (A) Three complete cycles of the 18.6-year nodal tidal cycle. (B) The residual tidal signal after the 18.6-year cycle is removed, showing an increase in tidal range over approximately the past 50 years; the rate change increased between 1951 and the early 1970s (Howes, 2009). 
observed changes in tidal range (Howes, 2009). The tidal record is clearly dominated by an 18.6-year cycle, but also contains a longer-term increase in tidal range underlying the 18.6-year cycle (fig. 58).

To identify the underlying trend, Howes (2009) applied a fast-Fourier transform to the long-term Grand Isle (1951-2006) tidal record (fig. 58) after removing the variance associated with the 18.6-year cycle signal. This analysis identified an increase in tidal range of $2.5-3.0 \mathrm{~cm}(0.98-1.18 \mathrm{in}$.) over the period of 1951-2006, which is an approximately 10 percent increase from 1951 levels. The analysis showed that the greatest rate of tidal-range increase occurred between 1950 and 1970, which coincided with peak rates of RSLR (fig. 59). After 1970, the tidal range stabilized. Howes (2009) hypothesized that the increase in tidal range is explained by the observed change in inlet hydraulics, in particular the increase in the hydraulic radius of Barataria Pass, which was a result of the larger tidal prism caused by high rates of RSLR and wetland loss. Qualitatively, the overall trends in both the hydraulic radius and tidal range are extremely similar, although data on hydraulic radius are limited to three points (fig. 59). To test this hypothesis, Howes (2009) applied a 1-D hydrodynamic model to hindcast the tidal range in the back-barrier bay immediately behind Barataria Pass. Using historical bathymetry data to determine past channel configuration and cross-sectional areas, he calculated the previous hydraulic radius and past inlet configuration. The model predicts an increase in tidal range stemming from the observed tidal-inlet evolution and establishes a previously unrecognized feedback between the inlet hydraulics and back barrier tidal range in Barataria. The model under-predicts the observed increase in tidal range obtained from the long-term gage record, but it confirms the existence of the process feedback.

The observed increase in tidal range has implications for restoration efforts. Traditionally in Louisiana, interior wetland loss in response to RSLR has been considered the sole mechanism contributing to the increase in tidal prism. However, Howes (2009) identified an internal feedback among back barrier wetland loss, inlet hydraulics, and a subsequent increase in tidal range. The increase in tidal range resulting from inlet alteration augments the initial response associated with wetland loss and may account for as much as 30 percent of the total increase in tidal prism over the period of the dataset. Restoration efforts should consider this effect and focus on maintaining the integrity of the barrier islands
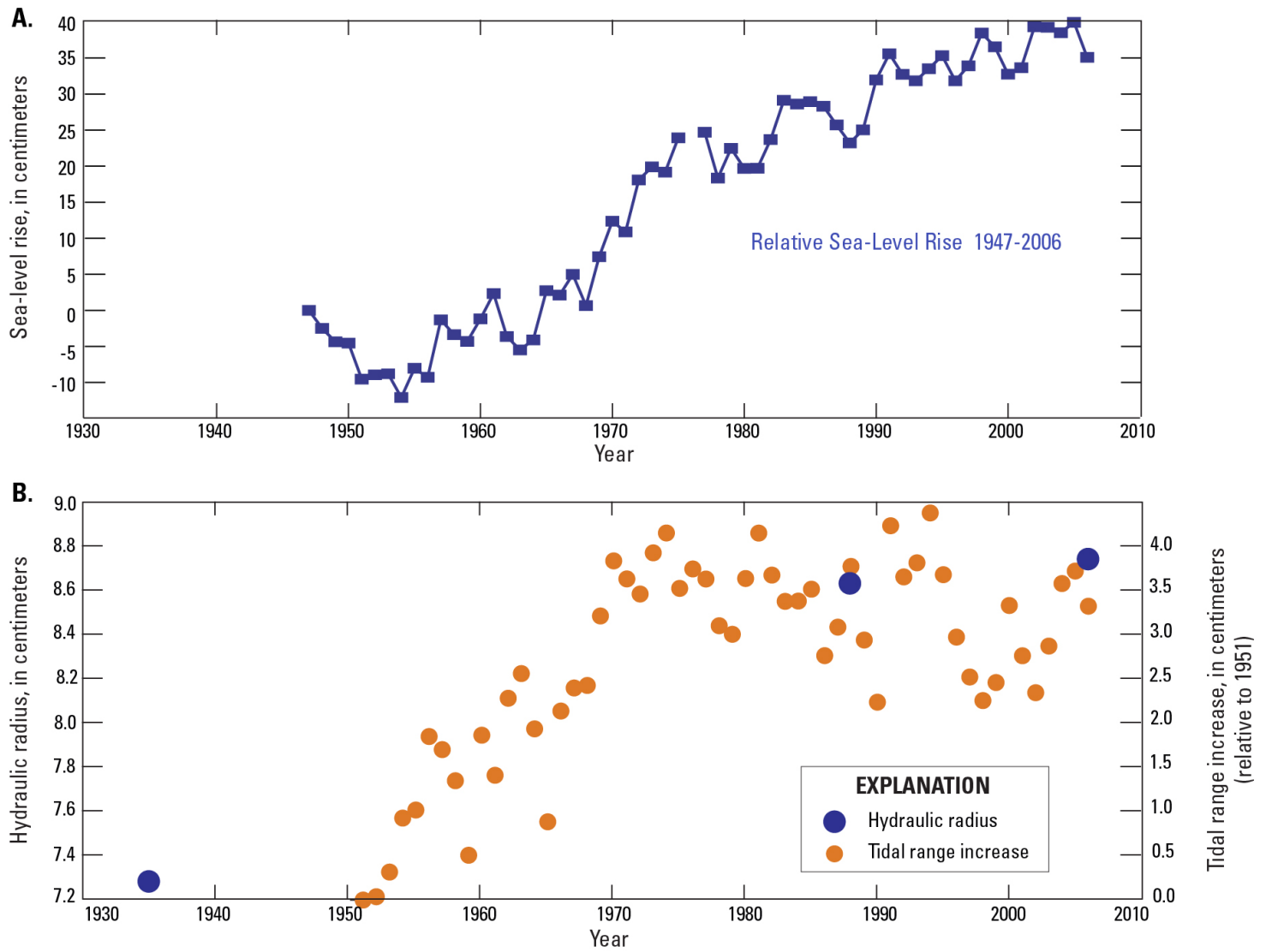

Figure 59. (A) Relative sea-level rise at Grand Isle, 1947-2006. (B) Hydraulic radius at Barataria Pass (blue points) and the increase in annual tidal range at Grand Isle relative to tidal range in 1951, as shown in figure 59 (Howes, 2009). 
and their inlets. The inlets are the effective agents in limiting back-barrier tidal range and thus prism, and as their crosssectional areas increase they become less effective at this process.

Once the tide propagates into Barataria Bay through the inlets, it continues into the basin as a progressive wave. The tide is gradually attenuated the farther it travels from the inlets. On a tropic cycle, the tide range decreases from $0.53 \mathrm{~m}(1.74 \mathrm{ft})$ at Barataria Pass to approximately $0.07 \mathrm{~cm}(0.28 \mathrm{in}$.$) at the Davis Pond diversion \sim 100 \mathrm{~km}(62.2 \mathrm{mi})$ up the basin. It takes approximately 13 hours for the high tide to travel from the inlet to Davis Pond. The style of tidal wave propagation also has implications for restoration and coastal management. Tidal prism is a volume of water and is calculated as a wetted area multiplied by a tidal range. On the basis of this concept, to optimize effectiveness land reclamation efforts should consider focusing on the lower portions of the basin, where the efforts may have a much greater impact in terms of reducing tidal prism on a per-unit-area basis, because the tidal range is greatest here. For example, a unit area of land will reduce tidal prism by $0.53 \mathrm{~m}^{3}\left(18.7 \mathrm{ft}^{3}\right)$ at Barataria Pass as opposed to $0.07 \mathrm{~m}^{3}\left(2.5 \mathrm{ft}^{3}\right)$ at Davis Pond, which is a factor of $\sim 7.5$. This conclusion is in opposition to a recent recommendation of Blum and Roberts (2009) that land be created in the upper portions of the basins. Blum and Roberts (2009) concluded that the modern sediment supply of the Mississippi River is insufficient to sustain the Louisiana deltaic plain in its entirety, especially in the face of accelerated sea-level rise, which is an important and indisputable point. However, the approach and recommendation of those authors are based on a passive sediment mass balance and omit the dynamics processes that govern coastal response and redistribute sediment. These dynamics processes provide restoration efforts some control over morphological change and the inevitable transgression on a decadal-centennial timescale. If the goal of a given restoration effort is to maximize overall restoration effectiveness on the entire basin then focusing on segments where effects of the tidal prism are greatest should be considered. In particular, the recommendation of those authors for land creation in the upper basin omits the central importance of tidal prism on coastal stability and does not consider the feedbacks between inlets and the back barrier that are especially relevant for coastal stability on the longer timescales. In addition, land creation in the upper basin would consist of low-salinity wetlands, which are more susceptible to erosion during the passage of storms than their high-salinity counterparts in the lower basin, as was observed during Hurricane Katrina in Breton Sound (Howes and others, 2010). Stemming the increase in tidal prism should be a central focus of restoration, since it is the only means by which to slow the erosion of inlets and the fragmentation of the barrier coast, which is especially relevant on a decadalcentennial timescale.

\section{Conclusions: Impacting Wetlands and Inlets in Central Louisiana}

The processes affecting Barataria Pass, Quatre Bayou Pass, Pass Abel, and Caminada Pass inlets are not unique to the Barataria Basin. Processes in this basin are an example of the far-reaching effects of RSLR on coastal land loss and the strong interaction and coupling between barrier-island and back-barrier systems. The coastline as a whole is changing, and no morphologic feature, habitat, or process is stable or independent from another. The observations and results presented by Howes (2009) (summarized above), are specific to Barataria Bay but are relevant to future changes along the entire coast. Howes' (2009) primary conclusions follow:

(1) The spatial pattern of wetland loss in the back barrier has a strong bearing on tidal exchange through the inlets and the increase in tidal prism. Wetland loss in the lower basin results in a larger increase in tidal prism per unit area of land lost due to the larger tidal range. As a consequence, restoration efforts directed at land reclamation should focus on the lower basin where they will have the greatest potential to effect tidal prism and stabilize the system on a per unit area basis.

(2) The cumulative cross-sectional area of the Barataria Bay inlets enlarged by $\sim 15,000 \mathrm{~m}^{2}\left(161,459 \mathrm{ft}^{2}\right)$ in response to back-barrier wetland loss and a larger tidal prism between 1890 and 2006. In the current barrier-shoreline configuration, the bay's tidal prism is distributed unevenly in the inlets. Barataria Pass controls nearly half of the tidal exchange between Barataria Bay and the Gulf of Mexico (48 percent), with Quatre Bayou contributing 23 percent, and Caminada Pass and Pass Abel supplying 14-15 percent, respectively.

(3) There are previously unrecognized complex coupling and dynamic feedbacks among back barrier wetland loss, inlet hydraulics, and tidal range. RSLR and the ensuing wetland loss forced significant changes in both the morphology and hydraulics of the tidal inlets, which in turn increased back-barrier tidal range. This coupling feedback compounds the initial back-barrier wetland loss and forms a substantial component of the trends in observed tidal prism, coastal erosion, and sediment redistribution and storage in offshore ebb-tidal deltas. Restoration efforts clearly benefit from a better understanding of these dynamic interactions. This understanding provides a potential to maximize the value of sediment input by focusing effort on key areas of the system, which can limit or reduce the rate of transgression and coastal land loss. 


\section{THEME 5: Habitat Changes Related to Long-Term Relative Sea-Level-Driven Erosion and Short-Term Storm-Driven Erosion}

Habitat change analyses by Fearnley, Brien, and others (2009d) showed that Hurricanes Katrina and Rita had a significant impact on coastal habitats within the BICM study areas. In several areas, low-lying habitats were inundated with water and eroded, resulting in a decrease in coastal habitat. In some areas, an increase in beach habitat was observed along the coastline as a result of sediment being moved inland with the storm surge. Overall, reductions in marsh, barrier vegetation, and intertidal-flat habitat due to the conversion to beach or open water can be attributed directly to hurricane impacts. The following sections describe the results of Fearnley, Brien, and others (2009d) habitat-change analyses for each BICM region based on data from 1996 or 1998, 2001 or 2002, 2004, and 2005; the last two datasets bracket the 2005 hurricane season.

\section{Pontchartrain Basin}

No habitat classification or change data were collected during the BICM project. This is an important data gap in the BICM program.

Mississippi River Delta Plain

\section{Chandeleur Islands (Breton Island to Hewes Point)}

Fearnley, Brien, and others (2009d) reported that the Chandeleur Islands experienced the greatest overall habitat change because of multiple hurricane impacts to the islands. After Hurricanes Isidore and Lili impacted the area in 2002, about half of the land area on Breton Island and almost all of Grand Gosier and Curlew Islands were converted to open water. These islands had recovered slightly by 2004, but all habitat types on Breton, Curlew, and Grand Gosier Islands were converted to open water in 2005 following the passage of Hurricane Katrina. Compared with the southern and central islands (Breton to Curlew Islands), the total habitat acreage on the northern Chandeleur Islands was relatively stable from 1998 to 2004. Higher elevations along the northern islands may have helped to mitigate the impacts of Hurricanes Isidore and Lili in this area. Like Breton, Grand Gosier, and Curlew Islands, however, all habitat types except some marsh areas were converted to open water in 2005.

\section{Modern Delta (Chaland Headland, Bay Joe Wise, Shell Island, Scofield, and Sandy Point)}

The relative acreage of habitats within the Modern Delta remained approximately constant between analyses despite the passage of Hurricanes Katrina and Rita. The acreage of intertidal habitat fluctuated but was likely a result of changes in water-level conditions between time periods and not a response to hurricane effects (Fearnley, Brien, and others, 2009d). In addition, the completion of several restoration projects in this area in 2006 and may have masked the results of the analysis.

Lafourche Delta (Timbalier Island, East Timbalier Island, the Caminada Headland, Grand Isle, Grand Terre Island, and East Grand Terre Island)

At Timbalier, East Timbalier, and Caminada Islands, overwash increased beach habitat, and a net decrease in marsh habitat and a total loss of barrier vegetation occurred on all three islands. Despite hurricane impacts, barrier vegetation and marsh habitat increased between 2004 and 2005, likely as a result of restoration efforts and the implementation of breakwaters. Grand Isle and Grand Terre experienced minimal impacts from the passage of the 2005 hurricanes, and restoration efforts at Grand Terre apparently increased marsh habitat at the expense of barrier vegetation (Fearnley, Brien, and others, 2009d). 
BICM Program Summary Report: Data and Analyses 2006 through 2010

Teche Delta (Isles Dernieres Chain from Raccoon Point to Wine Island Pass)

At Raccoon Island, hurricane overwash decreased marsh habitat and increased the acreage of beach and intertidal habitat. Whiskey Island marsh habitat proved resilient to washover; however, acreage of beach habitat was converted to open water, likely because of shoreline erosion. In addition, intertidal, marsh, and barrier-island vegetation lost significant acreage that was converted to beach. Hurricane impacts at Trinity Island included an increase in the acreage of beach and intertidal-flat habitat, despite the conversion of intertidal habitat to open water, because of habitat change from marsh and barrier-island vegetation to intertidal habitat. Washover increased the acreage of beach habitat at East Island, reducing intertidal-flat, marsh, and barrier-island habitats.

\section{Acadiana Bay}

No habitat classification or change data were collected during the BICM project. This is an important data gap in the BICM program.

\section{Chenier Plain (Ocean View to Hackberry Beaches)}

Total marsh habitat in the western Chenier Plain remained relatively constant from 1998 to 2005. Increased beach and marsh habitat between Holly and Constance Beaches between 2001 and 2004 were likely directly attributable to restoration efforts here. Reduced marsh and beach habitat acreages in 2005 were attributed to the passage of Hurricane Rita (Fearnley, Brien, and others, 2009d).

\section{THEME 6: Future Goals of the BICM Program}

To more effectively identify the magnitude, rates, and processes of shoreline change, a barrier-island comprehensive monitoring program (BICM) was developed as a framework for a coast-wide monitoring effort. A significant component of this effort includes documenting the historically dynamic morphologic evolution of the Louisiana nearshore, shoreline, and back-barrier environments. This aspect of the program is designed to complement other project-specific monitoring programs that are currently underway through the support of agencies such as CPRA and USACE.

In contrast to project-specific monitoring efforts, the BICM project provided more comprehensive, regionwide datasets. The methodologies developed under the BICM project allow efficient and accurate integration of historic and current datasets and provide a baseline that can be used in future assessments. This project provided long-term morphological data for all of Louisiana's barrier islands and mainland shorelines, rather than just those islands and areas that are slated for coastal restoration projects or have had construction previously completed. In addition, BICM specifically provided a larger proportion of unified, long-term datasets that will be available to monitor construction projects, plan and design future barrier-island projects, develop operation and maintenance activities, and assess the range of impacts created by past and future tropical storms. The development of coastal models, such as those quantifying littoral-sediment budgets, and a more advanced understanding of the mechanisms forcing coastal evolution become increasingly feasible with the availability of the BICM datasets. These factors constitute critically important elements of any effort that is aimed at effective coastal restoration, sediment nourishment, or management.

The intent of this theme is to provide guidance for developing a continuation of the BICM program based on results of BICM Phase 1, to outline an ongoing monitoring program, and to develop tools that can be readily applied by the end users. The original BICM program objectives remain unchanged (see Introduction) and are incorporated in the proposed future BICM efforts. Feedback and assessment of the initial phase of the BICM program indicates it has advanced coastal science and provided baseline data that will directly influence coastal management practices. The continuing program can fill in gaps and enhance its value with future monitoring that includes broader aspects of the physical environment. Additionally, the timing of data collections should be staggered to better utilize resources and enhance data collection. 


\section{Future BICM Monitoring}

\section{Semi-Decadal and Annual-Scale Monitoring of BICM Regions}

The initial BICM program established four geologic regions of the Louisiana coastal zone: Pontchartrain Basin, Mississippi River Delta Plain, Acadiana Bays, and the Chenier Plain. These regions would be monitored on a 5-year rotating basis, with measurement of physical parameters such as habitat type, topography and bathymetry, subsidence rates, and shoreline change. Presently, there are data gaps (for example, the Acadiana Bays region has very limited data), and additional efforts need to be focused in these areas to complete the comprehensive dataset. Several options may be considered: (1) revisiting each of the four geologic regions every 5 years on a rotating schedule until evaluation of the data collection determines optimum schedules that efficiently utilize resources and funding; (2) collecting all data for a geologic region simultaneously and rotating on a 5-year basis; or (3) collecting all of one data type in a single year (for example bathymetry or lidar) so that annual remobilization is not necessary. Scheduling data collection following storm impacts and to evaluate restoration and construction projects (such as at Shell Island and Whiskey Island) should also be considered and should be integrated with adaptive-management plans.

On an annual basis, coverage of the barrier shorelines (for example., Raccoon Point to Sandy Point and the Chandeleur Islands) would be targeted to quantify shoreline and seafloor change. These annual geophysical profiles would reoccupy select, evenly spaced, BICM baseline data but at an increased survey trackline spacing. This approach would not provide the coverage necessary to produce a surface model, as provided by the baseline and semidecadal-scale surveys, but would efficiently quantify the nearshore processes that drive barrier-island evolution in Louisiana, including annual storm impact. Reoccupying survey transects allows for direct comparison to quantify short-term trends in shoreface profiles and sediment dynamics. Quantifying these short-term rates and identifying their role in long-term evolution are critical for barrier-island-restoration project design, site selection, identification of sand sources and sinks, life-span predictions, and post-construction monitoring. The annual surveys would also characterize short-term change due to winter cold fronts and tropical storms.

\section{Proposed Data Collection}

The BICM program is a data-collection effort. Data collection and data products could be based on BICM protocols that have been developed through user comments, workshops, and planning meetings. Data collections emphasized here are primarily a continuation of established methods developed during existing BICM studies and suggested modifications. The different types of data collections listed below provide specific individual datasets, but when used in combination, a broader holistic view of the Louisiana coastal system can be developed.

(1) Barrier-Island Habitat Assessment: Oblique aerial photography and video could be used to document shoreline conditions, habitat type, and changes due to impacts from hurricanes and seasonal storms.

(2) Shoreline Change Assessment: Imagery (for example, Digital Orthophoto Quarter Quads (DOQQ's), Color Infrared (CIR) aerial photography or Digital Globe QuickBird satellite imagery) and lidar have been and could be used to monitor Louisiana shoreline-change rates. Assessment of the rates of shoreline change over time should drive planning for future aerial-photography surveys.

(3) Bathymetry: Changes in coastal bathymetry are critical to monitoring the impacts of tropical and seasonal storms, changes in sediment-transport patterns, and impacts of restoration efforts. The success of the initial BICM bathymetric surveys indicates that future surveys could be expanded to include additional innershelf and shoreline areas to provide the same management support to a broader region. Rates of change and impacts of storm events should drive the frequency of surveys. The near-surface geologic framework in these areas could also be characterized to determine the influence of the topography on coastal change.

(4) Topography: Barrier-island and shoreline elevations are critical for monitoring rates of changes in geomorphic features and sediment volumes. Lidar surveys are the most efficient and cost-effective datacollection method for this task. Lidar and bathymetric surveys could be coordinated to share resources, provide accurate integration, and enhance modeling efforts. 
BICM Program Summary Report: Data and Analyses 2006 through 2010

(5) Habitat: Continued habitat-classification analysis is critical to monitoring the impacts of relative sea-level rise, storms, restoration, and coastal-planning activities.

(6) Sediment Characterization: Changes in sediment character are typically an indicator of change in sediment transport and budget. Monitoring the coastal-sediment character in the BICM regions is crucial to evaluating restoration-project performance in addition to changes to unaltered systems.

(7) Subsidence: Monitoring of local subsidence rates will provide local rates of sea-level rise and establish elevation response to construction projects as opposed to natural changes. The need to incorporate local subsidence rates into restoration-project metrics has been identified and integrated into the Louisiana Coastal Master Plan (Beck and others, 2012). It is critical to identify the rate of subsidence in each BICM region and along each shoreline.

\section{Technology Advances}

Because data collection and processing are the primary activities of BICM, using the best and most current technologies should be an important objective. For example, technological advances in topographic and bathymetric data-collection and processing techniques, resolution, equipment, and software could be reviewed and applied to enhance monitoring and coastal-management practices. This would also hold true for all data collected (coastal imagery, lidar, habitat type). However, since the objective of the BICM program is to monitor change over time, baseline protocols and datums need be adhered to so that the datasets remain comparable.

\section{Standardization of Methods and Quality Control}

Standardization of methods would provide guidance and coordination that assures that all data collected under BICM efforts and by project-specific studies are conducted under a uniform set of standards so that they are comparable and complimentary. This would include, but is not limited to, data-collection locations and datums, precision of instrumentation/systems that are used for data collection, methodology/calibration techniques, and uncertainty analysis/ quality control. Data-collection planning, processing, and analysis could be overseen by a single entity to ensure uniformity and consistency with established standards. BICM-type datasets that are collected by other agencies or under project-specific objectives outside of BICM (for example, LCA or CWPPRA coastal-management projects) could be processed and incorporated into the more regional and longer-term monitoring efforts expected of the BICM program. Since the completion of this phase of BICM in 2010, CPRA has developed protocols for geophysical data acquisition that aids consultants to collect data in a uniform manner for inclusion into the Louisiana Sand Resources Database (LASARD) (Syed Khalil, oral commun., 2012).

\section{External Considerations}

The BICM program, as implemented, is primarily a data-collection and synthesis effort to monitor coastal change in specific regions of Louisiana. Several considerations, while not under BICM responsibilities, should be promoted to other projects and partners.

\section{Establishment of Hydrodynamic Monitoring Stations}

Monitoring stations that record wave, current, water level, salinity, temperature, and other such data statistics could be established at key locations including barrier-shoreface and proximal back-barrier environments and at tidal inlets. These data are critical for quantifying and modeling regional processes along the sandy shorelines and can provide information for external projects that in turn can contribute analysis and results to the BICM program. These stations would complement or be incorporated into the existing CRMS-Wetlands stations and future CRMS-Water stations as well as existing stations offshore (Wave-Current-Surge Information System for Coastal Louisiana [WAVCIS] and National Ocean Service [NOS]). 


\section{Development of Barrier-Island Value Assessment Model}

The goal of this task would be to develop an assessment tool that would replace or augment existing models (for example, Wetland Value Assessment [WVA]) presently used to quantify changes in habitat quality and quantity that are predicted as a result of proposed barrier-island-restoration projects. Based on findings in the BICM project and in previous studies along the Louisiana barrier islands, the existing WVA barrier-island and barrier-headland models do not consider some of the most critical barrier-island-system habitats (for example, marine submerged aquatic vegetation, back-barrier platform, barrier shoal, and submerged-spit platforms) and processes. Moreover, existing models put a priority on total area created as a result of the project and do not consider sediment volume or strategic placement of sediment that might provide increased island area in subsequent years post-construction due to natural sediment-transport trends, tidal processes, and aeolian processes. This tool would consider the unique morphodynamics of sandy barrier-island systems (including subsurface stratigraphy) for quantifying projected changes as a result of project construction and projected changes without construction and would allow for development of best practices and management for restoration.

\section{Data Management and User Tools}

A clear data-management system could be established that would allow researchers collecting and processing the data to seamlessly upload materials from offsite portals, archive data at various stages of development, and develop a template-based system to automatically generate end products to identical standards. This system would also be designed so that end users can efficiently obtain the data (temporally and spatially) as required for their specific missions from Webbased portals. This structure would also allow information to be accessed quickly and comprehensively for emergency response to natural and manmade disasters. 
BICM Program Summary Report: Data and Analyses 2006 through 2010

\section{References}

Barras, J.A., 2003, Historical and projected coastal Louisiana land changes: 1978-2050: U.S. Geological Survey OpenFile Report 2003-334, 39 p. (Also available at http://pubs.er.usgs.gov/publication/ofro3334/.)

Barras, J.A., 2006, Land area change in coastal Louisiana after the 2005 hurricanes: A series of three maps: U.S. Geological Survey Open-File Report 2006-1274, 3 p. (Also available at http://pubs.usgs.gov/of/2006/1274/.)

Barras, J., 2007, Land area changes in coastal Louisiana after Hurricanes Katrina and Rita, in Farris, G.S., Smith, G.J., Crane, M.P., Demas, C.R., Robbins, L.L., and Lavoie, D.L., eds., 2007, Science and the storms - the USGS response to the hurricanes of 2005: U.S. Geological Survey Circular 1306, 283 p. (Also available at http://pubs.usgs.gov/ circ/1306/.)

Barras, J.A., Bernier, J.C., and Morton, R.A., 2008, Land area change in coastal Louisiana-A multidecadal perspective (from 1956 to 2006): U.S. Geological Survey Scientific Investigations Map 3019, scale 1:250,000, 14 p. pamphlet. (Also available at $h t t p: / / p u b s . u s g s . g o v / s i m / 3019 /)$.

Barras, J., Beville, S., Britsch, D., Hartley, S., Hawes, S., Johnston, J., Kemp, P., Kinler, Q., Martucci, A., Porthouse, J., Reed, D., Roy, K., Sapkota, S., and Suhayda, J., 2003, Historical and projected coastal Louisiana land changes: 19782050: U.S. Geological Survey Open-File Report 03-334, 39 p. (Revised January 2004).

Beck, H., Bihler, A., Kemm, M., Pardo, S., and Perron, D., 2012, Physical and program options for the inland migration of Louisiana's coastal wetlands in response to relative sea level rise: A report for the Coastal Protection and Restoration Authority of Louisiana, $131 \mathrm{p}$.

Blum, M.D., and Roberts, H.H., 2009, Drowning of the Mississippi Delta due to insufficient sediment supply and global sea-level rise: Nature Geoscience, v. 2, p. 488-491.

Boyd, R., and Penland, S., 1981, Washover of deltaic barriers on the Louisiana coast: Gulf Coast Association of Geological Societies Transactions, v. 31, p. 243-248.

Boyd, R., and Penland, S., 1988, A geomorphologic model for Mississippi Delta evolution: Transactions of the Gulf Coast Association of Geological Societies, v. 38, p. 443-452.

Boyd, R., Suter, J.R., and Penland, S., 1989, Relation of sequence stratigraphy to modern sedimentary environments: Geology, v. 17, p. 926-929.

Brooks, G., Kindinger, J., Penland, S., Williams, S.J., and McBride, R., 1995, East Louisiana continental shelf sediments: A product of delta reworking: Journal of Coastal Research, v. 11, no. 4, p. 1026-1036.

Byrne, J.V., LeRoy, D.O., and Riley, C.M., 1959, The Chenier Plain and its stratigraphy, southwestern Louisiana: Gulf Coast Association of Geological Societies Transactions, v. 9, p. 237-259.

Cahoon, D., and Groat, C., 1990, Study of marsh-management practice in coastal Louisiana: Volume 2: Technical description: Gulf of Mexico Offshore Continental Shelf Region, Louisiana (United States): Final report submitted to U.S. Department of the Interior, Minerals Management Service, New Orleans, Louisiana Cooperative Agreement 14-12-0001-30410, $261 \mathrm{p}$.

Carter, J., 2008, Erosion control and sediment budget analysis: Grand Isle barrier shoreline stabilization study [abs.]: Louisiana Coastal Engineering Conference, Baton Rouge, Louisiana, Program with Abstracts, unpaginated.

Coastal Protection and Restoration Authority of Louisiana (CPRA), 2007, Integrated ecosystem restoration and hurricane protection: Louisiana's Comprehensive Master Plan for a Sustainable Coast: Louisiana Department of Natural Resources, Baton Rouge, Louisiana, 118 p.

Coastal Protection and Restoration Authority of Louisiana (CPRA), 2012, Integrated ecosystem restoration and hurricane protection: Louisiana's Comprehensive Master Plan for a Sustainable Coast: Louisiana Department of Natural Resources, Baton Rouge, Louisiana, 190 p. 
Coleman, J.M., 1981, Deltas, processes of deposition and models for exploration: Burgess, Minneapolis, Minnesota, 124 p.

Coleman, J.M., 1988, Dynamic changes and processes in the Mississippi River Delta: Geological Society of America Bulletin, v. 100, p. 999-1015.

Coleman, J., and Gagliano, S., 1964, Cyclic sedimentation in the Mississippi River deltaic plain: Gulf Coast Association of Geological Societies Transactions, v. 14, p. 67-80.

Courtemanche, R.P., Jr., Hester, M.W., and Mendelssohn, I.A., 1999, Recovery of a Louisiana barrier island marsh plant community following extensive hurricane-induced overwash: Journal of Coastal Research, v. 15, p. 872-883.

Couvillion, B.R., Barras, J.A., Steyer, G.D., Sleavin, W., Fischer, M., Beck, H., Trahan, N., Griffin, B., and Heckman, D., 2011, Land area change in coastal Louisiana from 1932 to 2010: U.S. Geological Survey Scientific Investigations Map 3164, scale 1:265,000, 15 p. (Also available at http://pubs.er.usgs.gov/publication/sim3164/.)

Curray, J.R., 1960, Sediments and history of Holocene transgression, continental shelf, northwest Gulf of Mexico: Recent sediments, northwest Gulf of Mexico, v. 45, no. 4, p. 221-266.

Dahl, T.E., 2009, Status and trends of wetlands in the conterminous United States 2004-2009: U.S. Fish and Wildlife Service, Fisheries and Habitat Conservation, Washington, D.C., 112 p.

DeWitt, N.T., Flocks, J.G., Hansen, M., Kulp, M., and Reynolds, B.J., 2007, Bathymetric survey of the nearshore from Belle Pass to Caminada Pass, Louisiana: Methods and data report: U.S. Geological Survey Data Series 312. (Also available at $h t t p: / / p u b s . e r . u s g s . g o v / p u b l i c a t i o n / d s 312 /$.

Divins, D.L., and Metzger, D., 2008, NGDC Coastal Relief Model, http://www.ngdc.noaa.gov/mgg/coastal/coastal.html.

Doran, K.J., Sallenger, A.H., Reynolds, B.J., and Wright, C.W., 2009, Accuracy of EAARL lidar ground elevations using a bare-earth algorithm in marsh and beach grasses on the Chandeleur Islands, Louisiana: U.S. Geological Survey OpenFile Report 2010-1163, 9 p. (Also available at http://pubs.usgs.gov/of/2010/1163/.)

Draut, A.E., Kineke, G.C., Huh, O.K., Grymes, J.M., III, Westphal, K.A., and Moeller, C.C., 2005, Coastal mudflat accretion under energetic conditions, Louisiana Chenier-Plain coast, USA: Marine Geology, v. 214, p. $27-47$.

Dunbar, J.B., Britsch, L.D., and Kemp, E.B., 1992, Land loss rates: Louisiana coastal plain: Technical Report GL-90-2, Report 3 of a series, U.S. Army Corps of Engineers, Waterways Experiment Station, Vicksburg, Mississippi, 66 p.

Faulkner, S., Barrow, W., Couvillion, B., Conner, W., Randall, L., and Baldwin, M., 2007, Impacts of Hurricane Katrina on floodplain forests of the Pearl River, in Farris, G.S., Smith, G.J., Crane, M.P., Demas, C.R., Robbins, L.L., and Lavoie, D.L., eds., 2007, Science and the storms - the USGS response to the hurricanes of 2005: U.S. Geological Survey Circular 1306, 283 p. (Also available at http://pubs.usgs.gov/circ/1306/.)

Fearnley, S., Brien, L., Martinez, L., Miner, M., Kulp, M., and Penland, S., 2009a, Louisiana barrier-island comprehensive monitoring program (BICM) - Volume 5: Chenier Plain, south-central Louisiana, and Chandeleur Islands, habitat mapping and change analysis 1996 to 2005, Part 1: Methods for habitat mapping and change analysis 1996 to 2005: Prepared for the Louisiana Department of Natural Resources, Coastal Restoration Division by the University of New Orleans, Pontchartrain Institute for Environmental Sciences, New Orleans, Louisiana, 11 p.

Fearnley, S., Brien, L., Martinez, L., Miner, M., Kulp, M., and Penland, S., 2009b, Louisiana barrier-island comprehensive monitoring program (BICM) - Volume 5: Chenier Plain, south-central Louisiana, and Chandeleur Islands, habitat mapping and change analysis 1996 to 2005, Part 2: Habitat, land loss, and mosaic maps: Prepared for the Louisiana Department of Natural Resources, Coastal Restoration Division by the University of New Orleans, Pontchartrain Institute for Environmental Sciences, New Orleans, Louisiana, 296 p.

Fearnley, S., Brien, L., Martinez, L., Miner, M., Kulp, M., and Penland, S., 2009c, Louisiana barrier-island comprehensive monitoring program (BICM) - Volume 5: Chenier Plain, south-central Louisiana, and Chandeleur Islands, habitat mapping and change analysis 1996 to 2005, Part 3: Habitat class tables, habitat change tables, and final statistics 1996 to 2005: Prepared for the Louisiana Department of Natural Resources, Coastal Restoration Division by the University 
BICM Program Summary Report: Data and Analyses 2006 through 2010

of New Orleans, Pontchartrain Institute for Environmental Sciences, New Orleans, Louisiana, 78 p.

Fearnley, S., Brien, L., Martinez, L., Miner, M., Kulp, M., and Penland, S., 2009d, Louisiana barrier-island comprehensive monitoring program (BICM) - Volume 5: Chenier Plain, south-central Louisiana, and Chandeleur Islands, habitat mapping and change analysis 1996 to 2005, Part 4: Results and interpretations of the habitat mapping and change analysis 1996 to 2005: Prepared for the Louisiana Department of Natural Resources, Coastal Restoration Division by the University of New Orleans, Pontchartrain Institute for Environmental Sciences. New Orleans, Louisiana, 28 p.

Fearnley, S., Miner, M., Kulp, M., Bohling, C., Martinez, L., and Penland, S., 2009, Hurricane impact and recovery shoreline change analysis and historical island configuration-1700s to 2005, in Lavoie, D., ed., Sand resources, regional geology, and coastal processes of the Chandeleur Islands coastal system: an evaluation of the Breton National Wildlife Refuge: U.S. Geological Survey Scientific Investigations Report 2009-5252, p. 7-26. (Also available at http://pubs.usgs.gov/sir/2009/5252/.)

Fearnley, S., Miner, M.D., Kulp, M.A., Bohling, C., and Penland, S., 2009, Hurricane impact and recovery shoreline change analysis of the Chandeleur Islands, Louisiana, USA: 1855 to 2005: Geo-Marine Letters, v. 29, no. 6, p. 455-466.

Fisk, H.N., 1944, Geological investigation of the alluvial valley of the lower Mississippi River: U.S. Army Corps of Engineers, Mississippi River Commission, Vicksburg, Mississippi, 78 p.

Fisk, H.N., 1955, Sand facies of the recent Mississippi Delta deposits: Proceedings, 4th World Petroleum Congress, Rome, Italy, Section 1-C, p. 377-398.

Fisk, H.N., 1961, Bar-finger sands of the Mississippi delta, in Geometry of Sandstone Bodies - a Symposium: Proceedings of the Symposium at the 45th Annual Meeting of the American Association of Petroleum Geologists; 1960 April 2528 (Atlantic City, New Jersey): Tulsa, Oklahoma, American Association of Petroleum Geologists, p. 29-52.

FitzGerald, D.M., Kulp, M.A., Huges, Z., Georgiou, I., Miner, M.D., Penland, S., and Howes, N., 2007, Impacts of rising sea level to backbarrier wetlands, tidal inlets, and barrier islands: Barataria Coast, Louisiana, in Proceedings, Coastal Sediments ‘07, American Society of Civil Engineers, New Orleans, Louisiana, p. 1179-1192.

FitzGerald, D.M., Kulp, M.A., Penland, S., Flocks, J., and Kindinger, J., 2004, Morphologic and stratigraphic evolution of muddy ebb-tidal deltas along a subsiding coast: Barataria Bay, Mississippi River Delta: Sedimentology, v. 51, p. $1157-1178$.

Flocks, J., Kindinger, J., Marot, M., and Holmes, C., 2009b, Sediment characterization and dynamics in Lake Pontchartrain: Journal of Coastal Research, Special Issue No. 54, p. 113-126.

Flocks, J.G., Kindinger, J.L., and Swarzenski, P.W., 2002, Sediment-hosted contaminants and distribution patterns in the Mississippi and Atchafalaya River Deltas: Gulf Coast Association of Geological Societies Transactions, v. 52, p. $277-290$.

Flocks, J., Kulp, M., Smith, J., and Williams, S.J., 2009, Review of the geologic history of the Pontchartrain Basin, northern Gulf of Mexico: Journal of Coastal Research, Special Issue No. 54, p. 12-22.

Flocks, J., Miner, M., Twichell, D., Lavoie, D., and Kindinger, J., 2009, Evolution and preservation potential of fluvial and transgressive deposits on the Louisiana inner shelf: Understanding depositional processes to support coastal management: Geo-Marine Letters, v. 29, p. 359-378.

Flocks, J., Miselis, J., Plant, N., and Sallenger, A., 2011, The northern Chandeleur Islands and the emergency oil spill mitigation sand berm: A proxy for shoreline response to largescale revitalization projects? [abs.]: Basics of the Basin Symposium, Hammond, Louisiana, 4 p.

Flocks, J., Twichell, D., Sanford, J., Pendleton, E., and Baldwin, W., 2009, Sediment sampling analysis to define quality of sand resources, in Lavoie, D., ed., Sand resources, regional geology, and coastal processes of the Chandeleur Islands coastal system - An evaluation of the Breton National Wildlife Refuge: U.S. Geological Survey Scientific Investigations Report 2009-5252, p. 197-245. (Also available at http://pubs.usgs.gov/sir/2009/5252/.) 
Frazier, D.E., 1967, Recent deltaic deposits of the Mississippi River: Their development and chronology: Gulf Coast Association of Geological Societies Transactions, v. 17, p. 287-315.

Frazier, D.E., 1974, Depositional episodes: Their relationship to the Quaternary stratigraphic framework in the northwestern portion of the Gulf Basin: Bureau of Economic Geology, Circular 74-1, 28 p.

Fry, J., Xian, G., Jin, S., Dewitz, J., Homer, C., Yang, L., Barnes, C., Herold, N., and Wickham, J., 2011, Completion of the 2006 national land cover database for the conterminous United States: Photogrammetric Engineering and Remote Sensing, v. 77, no. 9, p. 858-864.

Georgiou, I.Y., FitzGerald, D.M., and Stone, G.W., 2005, The impact of physical processes along the Louisiana coast: Journal of Coastal Research, Special Issue No. 44, p. 72-89.

Gesch, D., 2007, Topography-based analysis of Hurricane Katrina inundation of New Orleans, in Farris, G.S., Smith, G.J., Crane, M.P., Demas, C.R., Robbins, L.L., and Lavoie, D.L., eds., 2007, Science and the storms- the USGS response to the hurricanes of 2005: U.S. Geological Survey Circular 1306, 283 p. (Also available at http://pubs.usgs.gov/ circ/1306/.)

Gould, H.R., and McFarlan, E., Jr., 1959, Geologic history of the Chenier Plain, southwestern Louisiana: Gulf Coast Association of Geological Societies Transactions, v. 9, p. 261-272.

Hansen, M., and Howd, P., 2009, Louisiana barrier-island comprehensive monitoring program (BICM) - Volume 4: Louisiana light detection and ranging data (lidar) Part 1: Lidar systems and data processing techniques: Prepared for the Louisiana Department of Natural Resources, Coastal Restoration Division by the University of New Orleans, Pontchartrain Institute for Environmental Sciences, New Orleans, Louisiana, 22 p.

Hartley, S., Pace, R., III, Johnston, J.B., Swan, M., O’Neil, C., Handley, L., and Smith, L., 2000, A GAP analysis of Louisiana (1993): U.S. Geological Survey National Wetlands Research Center, Lafayette, Louisiana, 588 p. (Also available at http://sabdata.cr.usgs.gov/sabnet/priv/net_pub_products/DOC/2000-02-0139.pdf.)

Heitmuller, P., and Perez, B., 2007, Environmental impact of Hurricane Katrina on Lake Pontchartrain, in Farris, G.S., Smith, G.J., Crane, M.P., Demas, C.R., Robbins, L.L., and Lavoie, D.L., eds., 2007, Science and the storms - the USGS response to the hurricanes of 2005: U.S. Geological Survey Circular 1306, 283 p. (Also available at http://pubs. usgs.gov/circ/1306/.)

Howes, N.C., 2009, The impact of wetland loss on inlet morphology and tidal range within Barataria Bay, Louisiana: Boston University, Boston, Massachusetts, M.S. thesis, 95 p.

Howes, N.C., FitzGerald, D.M., Hughes, Z.J., Georgiou, I.Y., Kulp, M.A., Miner, M.D., Smith, J.M., and Barras, J.A., 2010, Hurricane-induced failure of low salinity wetlands: Proceedings of the National Academy of Sciences, v. 107, no. 32, p. $14014-14019$.

Huh, O.K., Walker, N.D., and Moeller, C., 2001, Sedimentation along the eastern Chenier Plain coast: Downdrift impact of a delta complex shift: Journal of Coastal Research, v. 17, p. 72-81.

Jaffe, B.E., List, J.H., and Sallenger, A.H., Jr., 1997, Massive sediment bypassing on the lower shoreface of a wide tidal inlet - Cat Island Pass, Louisiana: Marine Geology, v. 136, p. 131-149.

Kindinger, J., Penland, S., Flocks, J., Kulp, M., and Britsch, D., 2001, Sand resources, regional geology, and coastal processes for the restoration of the Barataria barrier shoreline: U.S. Geological Survey Open-File Report 2001-384, 70 p. (Also available at $h t t p: / / p u b s . e r . u s g s . g o v / p u b l i c a t i o n / o f r 01384$.

Knabb, R., Rhome, J., and Brown, D., 2005, Tropical cyclone report: Hurricane Katrina 23-30 August, 2005: National Hurricane Center, Miami, Florida, 43 p. (Also available at http://www.nhc.noaa.gov/pdf/TCR-AL122005_Katrina.pdf.)

Kolb, C.R., and Van Lopik, J.R., 1958, Geology of the Mississippi River deltaic plain, southeastern Louisiana: Vicksburg, Mississippi: U.S. Army Corp of Engineers, Waterways Experimental Station, Technical Report 3-483, 120 p.

Kulp, M.A., FitzGerald, D.M., and Penland, S., 2005, Sand-rich lithosomes of the Holocene Mississippi River delta plain, 
BICM Program Summary Report: Data and Analyses 2006 through 2010

in Liviu, G., and Bhattacharya, J.P., eds., River deltas: Concepts, models, and examples: Society for Sedimentary Geology (SEPM), Special Publication 83, p. 279-293.

Kulp, M.A., Miner, M., Weathers, D., Motti, J., McCarty, P., Brown, M., Labold, J., Boudreaux, A., Flocks, J.G., and Taylor, C., 2011a, Louisiana barrier-island comprehensive monitoring program (BICM) - Volume 6, Part A: Characterization of Louisiana Coastal Zone sediment samples: Backbarrier through offshore samples of the Chenier Plain, south central barrier island systems and Chandeleur Islands: Prepared for the Louisiana Department of Natural Resources, Coastal Restoration Division by the University of New Orleans, Pontchartrain Institute for Environmental Sciences, New Orleans, Louisiana, 11 p.

Kulp, M.A., Miner, M., Weathers, D., Motti, J., McCarty, P.P., Brown, M., Labold, J., Boudreaux, A., Flocks, J.G., and Taylor, C., 2011b, Louisiana barrier-island comprehensive monitoring program (BICM) - Volume 6, Part B: Characterization of Louisiana Coastal Zone sediment samples: Backbarrier through offshore samples of the Chenier Plain, south-central barrier island systems and Chandeleur Islands: Prepared for the Louisiana Department of Natural Resources, Coastal Restoration Division by the University of New Orleans, Pontchartrain Institute for Environmental Sciences, New Orleans, Louisiana, 39 p.

Lavoie, D., ed., 2009, Sand resources, regional geology, and coastal processes of the Chandeleur Islands coastal systemAn evaluation of the Breton National Wildlife Refuge: U.S. Geological Survey Scientific Investigations Report 2009$5252,180 \mathrm{p}$.

Levin, D.R., 1995, Occupation of a relict distributary system by a new tidal inlet, Quatre Bayou Pass, Louisiana, in Flemming, B.W., and Bartholoma, A., eds., Tidal signatures in modern and ancient sediments: International Association of Sedimentologists Special Publication 24, p. 71-84.

Linscombe, R.G., and Hartley, S.B., 2011, Analysis of change in marsh types of coastal Louisiana, 1978-2001: U.S. Geological Survey Open-File Report 2010-1282, 52 p. (Also available at http://pubs.usgs.gov/of/2010/1282/.)

List, J.H., Jaffe, B.E., Sallenger, A.H., and Hansen, M.E., 1997, Bathymetric comparisons adjacent to the Louisiana barrier islands: Processes of large-scale change: Journal of Coastal Research, v. 13, no. 3, p. 670-685.

List, J.H., Jaffe, B.E., Sallenger, A.H., Williams, S.J., McBride, R.A., and Penland, S., 1994, Louisiana barrier island erosion study: Atlas of seafloor changes from 1878 to 1989: U.S. Geological Survey and Louisiana State University, Miscellaneous Investigations Series I-2150-A, 81 p.

List, J.H., and Terwindt, J.H.J., 1995, Large-scale coastal behavior, in List, J.H., and Terwindt, J.H.J., eds., Large-scale coastal behavior: Marine Geology, v. 126, issues 1-4, 331 p.

Louisiana Coastal Area [LCA] Adaptive-Management Framework Team, 2010, LCA Program: Terrebonne Basin Barrier Shoreline Project Feasibility-Level Monitoring and Adaptive Management Plan: Final plan to U.S. Army Corps of Engineers and Louisiana Office of Coastal Protection and Restoration, New Orleans, Louisiana, 42 p.

Louisiana Coastal Wetlands Conservation and Restoration Task Force (LCWCRTF), 2002a, Whiskey Island restoration (TE-27): Louisiana Department of Natural Resources, Baton Rouge, Louisiana, 2 p. (Also available at http://lacoast. gov/reports/gpfs/TE-27.pdf.)

Louisiana Coastal Wetlands Conservation and Restoration Task Force (LCWCRTF), 2002b, Raccoon Island breakwaters demonstration (TE-29): Louisiana Department of Natural Resources, Baton Rouge, Louisiana, 2 p. (Also available at http://lacoast.gov/reports/gpfs/TE-29.pdf.)

Louisiana Coastal Wetlands Conservation and Restoration Task Force (LCWCRTF), 2002c, East Timbalier Island sediment restoration, Phase 1 (TE-25): Louisiana Department of Natural Resources, Baton Rouge, Louisiana, 2 p. (Also available at $h t t p: / / l a c o a s t . g o v /$ reports/gpfs/TE-25.pdf.)

Louisiana Coastal Wetlands Conservation and Restoration Task Force (LCWCRTF), 2002d, East Timbalier Island sediment restoration, Phase 2 (TE-30): Louisiana Department of Natural Resources, Baton Rouge, Louisiana, 2 p. 
(Also available at $h t t p: / / l a c o a s t . g o v / r e p o r t s / g p f s / T E-30 . p d f$.

Louisiana Coastal Wetlands Conservation and Restoration Task Force, 2002e, Hydrologic investigation of the Louisiana Chenier Plain: Louisiana Department of Natural Resources, Coastal Restoration Division, Baton Rouge, Louisiana, 135 p., plus appendices.

Louisiana Coastal Wetlands Conservation and Restoration Task Force (LCWCRTF), 2004, Holly Beach sand management (CS-31): Louisiana Department of Natural Resources, Baton Rouge, Louisiana, 2 p. (Also available at http://lacoast. gov/reports/gpfs/CS-31.pdf.)

Louisiana Coastal Wetlands Conservation and Restoration Task Force (LCWCRTF), 2007, New Cut dune and marsh restoration (TE-37): Louisiana Department of Natural Resources, Baton Rouge, Louisiana, 2 p. (Also available at http://lacoast.gov/reports/gpfs/TE-37.pdf.)

Louisiana Coastal Wetlands Conservation and Restoration Task Force (LCWCRTF), 2008, Vegetative plantings of a dredged material disposal site on Grand Terre Island (BA-28): Louisiana Department of Natural Resources, Baton Rouge, Louisiana, 2 p. (Also available at $h t t p: / / l a c o a s t . g o v / r e p o r t s / g p f s / B A-28 . p d f$.)

Louisiana Coastal Wetlands Conservation and Restoration Task Force (LCWCRTF), and Wetlands Conservation and Restoration Authority (WCRA), 1998, Coast 2050: Toward a sustainable coastal Louisiana: Louisiana Department of Natural Resources, Baton Rouge, Louisiana, 161 p., plus appendices.

Martinez, L., O’Brien, S., Bethel, M., Penland, S., and Kulp, M., 2009, Louisiana barrier-island comprehensive monitoring program (BICM), Volume 2: Shoreline changes and barrier-island land loss 1880s to 2005: Prepared for the Louisiana Department of Natural Resources, Coastal Restoration Division by the University of New Orleans, Pontchartrain Institute for Environmental Sciences, New Orleans, Louisiana, 32 p.

Martinez, L., Penland, S., Fearnley, S., O’Brien, S., Bethel, M., and Guarisco, P., 2009, Louisiana barrier-island comprehensive monitoring program (BICM) - Task 3: Shoreline change analysis 1800s to 2005: Pontchartrain Institute for Environmental Sciences, Technical Report No. 001-2008, University of New Orleans, New Orleans, Louisiana, $27 \mathrm{p}$.

McBride, R.A., Penland, S., Hiland, M.W., Williams, S.J., Westphal, K.A., Jaffe, B.E., and Sallenger, A.H., Jr., 1992, Analysis of barrier shoreline change in Louisiana from 1853 to 1989, in Williams, S.J., Penland, S., and Sallenger, A.H., eds., Louisiana barrier island erosion study, Atlas of shoreline changes in Louisiana from 1853 to 1989: U.S. Geological Survey and Louisiana State University, Miscellaneous Investigations Series I-2150-A, p. 36-97.

McBride, R.A., Taylor, M.J., and Byrnes, M.R., 2007, Coastal morphodynamics and Chenier-Plain evolution in southwestern Louisiana, USA: A geomorphic model. Geomorphology, v. 88, p. 367-422.

McCorquodale, J.A., Roblin, R., Georgiou, I., and Haralampides, K., 2009, Salinity, nutrient, and sediment dynamics in the Pontchartrain Estuary: Journal of Coastal Research, Special Issue No. 54, p. 113-126.

Meselhe, E., and Miller, R., 2009, Hydrologic modeling and budget analysis of the southwestern Louisiana Chenier Plain, Part I: Regional model: Final report to the Louisiana Coastal Area Science and Technology Program Office, State of Louisiana Interagency Agreement 2503-06-16, 219 p. (Also available at http://el.erdc.usace.army.mil/lcast/pdfs/ Chenier\%20Plain\%20-\%20Report\%20I.pdf.)

Miner, M.D., FitzGerald, D.M., and Kulp, M.A., 2007, 1880 to 2005 Morphologic evolution of a transgressive tidal inlet, Little Pass Timbalier, Louisiana, in Proceedings, Coastal Sediments '07, American Society of Civil Engineers, New Orleans, Louisiana, p. 1165-1178.

Miner, M.D., Kulp, M.A., FitzGerald, D.M., Flocks, J.G., and Weathers, H.D., 2009, Delta lobe degradation and hurricane impacts governing large-scale coastal behavior, south-central Louisiana, USA: Geo-Marine Letters, v. 29, p. 441-453.

Miner, M.D., Kulp, M.A., FitzGerald, D.M., and Georgiou, I.Y., 2009, Hurricane-associated ebb-tidal delta sediment dynamics: Geology, v. 37, no. 9, p. 851-854. 
BICM Program Summary Report: Data and Analyses 2006 through 2010

Miner, M., Kulp, M.A., Motti, J., Weathers, D., McCarty, P., Brown, M., Torres, J., Martinez, L., Flocks, J., Dewitt, N., Ferina, N., Reynolds, B.J., Twichell, D., Baldwin, W., Danforth, B., Worley, C., and Bergeron, E., 2009, Louisiana barrier-island comprehensive monitoring program (BICM) - Volume 3: Bathymetry and historical seafloor change 1869-2007, Part 2: South central Louisiana and northern Chandeleur Islands, bathymetry maps: Prepared for the Louisiana Department of Natural Resources, Coastal Restoration Division by the University of New Orleans, Pontchartrain Institute for Environmental Sciences, New Orleans, Louisiana, 27 p.

Miner, M., Kulp, M.A., Penland, S., Weathers, D., Motti, J., McCarty, P., Brown, M., Martinez, L., Torres, J., Flocks, J., Dewitt, N., Ferina, N., Reynolds, B.J., Twichell, D., Baldwin, W., Danforth, B., Worley, C., and Bergeron, E., 2009, Louisiana barrier-island comprehensive monitoring program (BICM) - Volume 3: Bathymetry and historical seafloor change 1869-2007, Part 1: Bathymetry methods and error analysis: Prepared for the Louisiana Department of Natural Resources, Coastal Restoration Division by the University of New Orleans, Pontchartrain Institute for Environmental Sciences, New Orleans, Louisiana, 45 p.

Miner, M.D., Kulp, M., Weathers, H.D., and Flocks, J., 2009, Historical (1869-2007) seafloor evolution and sediment dynamics along the Chandeleur Islands, in Lavoie, D., ed., Sand resources, regional geology, and coastal processes of the Chandeleur Islands coastal system - An evaluation of the Breton National Wildlife Refuge: U.S. Geological Survey Scientific Investigations Report 2009-5252, p. 47-74. (Also available at http://pubs.usgs.gov/sir/2009/5252/.)

Miner, M., Kulp, M.A., Weathers, D., Motti, J., McCarty, P., Brown, M., Torres, J., Martinez, L., Flocks, J., Dewitt, N., Ferina, N., Reynolds, B.J., Twichell, D., Baldwin, W., Danforth, B., Worley, C., and Bergeron, E., 2009, Louisiana barrier-island comprehensive monitoring program (BICM) - Volume 3: Bathymetry and historical seafloor change 1869-2007, Part 3: Southern Chandeleur Islands and western Chenier beaches, bathymetry maps: Prepared for the Louisiana Department of Natural Resources, Coastal Restoration Division by the University of New Orleans, Pontchartrain Institute for Environmental Sciences, New Orleans, Louisiana, 16 p.

Miner, M., Weathers, D., Kulp, M.A., and Rafferty, R., 2011, Louisiana barrier-island comprehensive monitoring program (BICM) - Volume 3: Bathymetry and historical seafloor change 1869-2007, Part 4: Historical seafloor change analysis: Prepared for the Louisiana Department of Natural Resources, Coastal Restoration Division by the University of New Orleans, Pontchartrain Institute for Environmental Sciences, New Orleans, Louisiana, 36 p.

Morgan, J.P., Nichols, L.G., and Wright, M., 1958, Morphological effects of Hurricane Audrey on the Louisiana coast: Louisiana State University Coastal Studies Institute, Technical Report, Baton Rouge, no. 10, 53 p.

Morgan, K.L.M., 2009, Louisiana barrier-island comprehensive monitoring program (BICM) - Volume 4: Louisiana light detection and ranging data (lidar), Part 2: Lidar flight path maps: Prepared for the Louisiana Department of Natural Resources, Coastal Restoration Division by the University of New Orleans, Pontchartrain Institute for Environmental Sciences, New Orleans, Louisiana, 32 p.

Morton, R.A., and Barras, J.A., 2011, Hurricane impacts on coastal wetlands: A half-century record of storm-generated features from southern Louisiana: Journal of Coastal Research, v. 27, no. 6A, p. 27-43.

Morton, R.A., and Bernier, J., 2010, Recent subsidence-rate reductions in the Mississippi Delta and their geological implications: Journal of Coastal Research, v. 26, p. 555-561.

Morton, R., Bernier, J., Kelso, K., and Barras, J., 2010, Quantifying large-scale historical formation of accommodation in the Mississippi Delta: Earth Surface Processes and Landforms v. 35, no. 14, p. 1625-1641.

Morton, R., Miller, T., and Moore, L., 2004, National assessment of shoreline change: Part 1: Historical shoreline changes and associated coastal land loss along the U.S. Gulf of Mexico: U.S. Department of the Interior, U.S. Geological Survey Open-File Report 2004-1043, 42 p. (Also available at http://pubs.usgs.gov/of/2004/1043/.)

Morton, R.A., and Sallenger, A.H., Jr., 2003, Morphological impacts of extreme storms on sandy beaches and barriers: Journal of Coastal Research, v. 1, no. 3, p. 560-573.

National Inventory Report (NIR), 2008, Inventory of U.S. greenhouse gas emissions and sinks: 1990-2006: U.S. 
Environmental Protection Agency, EPA 430-R-08-005, Washington, D.C., 360 p. (Also available at http://www.epa. gov/climatechange/ghgemissions/usinventoryreport/archive.html.)

National Inventory Report (NIR), 2010, Inventory of U.S. greenhouse gas emissions and sinks: 1990-2008: U.S. Environmental Protection Agency, EPA 430-R-10-006, Washington, D.C., 376 p. (Also available at http://www.epa. gov/climatechange/ghgemissions/usinventoryreport/archive.html.)

National Oceanic and Atmospheric Administration, 2010, Historical hurricane tracks: Accessed December 3, 2012, at http://www.csc.noaa.gov/hurricanes/\#.

Neill, C.F., and Allison, M.A., 2005, Subaqueous deltaic formation on the Atchafalaya shelf, Louisiana: Marine Geology, v. 214, p. 411-430.

Nyman, J.A., Crozier, C.R., and Delaune, R.D., 1995, Roles and patterns of hurricane sedimentation in an estuarine marsh landscape: Estuarine, Coastal and Shelf Science, v. 40, p. 665-679.

Owens, E., and Frobel, D.H., 1977, Ridge and runnel systems in the Magdelan Islands, Quebec: Journal of Sedimentary Petrology, v. 47, no. 1, p. 191-198.

Penland, S., Beall, A., Britsch, D., and Williams, S.J., 2002, Environmental issues-Coastal land loss, in Penland, S., Beall, A., and Kindinger, J., eds., Environmental atlas of the Lake Pontchartrain Basin: U.S. Geological Survey OpenFile Report 02-206, available online only at http://pubs.usgs.gov/of/2002/of02-206/index.html.

Penland, S., Beall, A., and Kindinger, J., 2002, eds., Environmental atlas of the Lake Pontchartrain Basin: U.S. Geological Survey Open-File Report 02-206, available online only at http://pubs.usgs.gov/of/2002/of02-206/index.html.

Penland, S., Beall, A., and Maygarden, D., 2002, Environmental status and trends of the Lake Pontchartrain Basin, in Penland, S., Beall, A., and Kindinger, J., eds., Environmental atlas of the Lake Pontchartrain Basin: U.S. Geological Survey Open-File Report 02-206, available online only at http://pubs.usgs.gov/of/2002/of02-206/index.html.

Penland, S., and Boyd, R., 1981, Shoreline changes on the Louisiana coast: Oceans, v. 91, p. 209-219.

Penland, S., and Boyd, R., 1985, Transgressive depositional environments of the Mississippi River delta plain: A guide to the barrier islands, shoals, and beaches in Louisiana: Louisiana State Geological Survey Guidebook Series, No. 3, Baton Rouge, Louisiana, Louisiana Geological Survey, 233 p.

Penland, S., Boyd, R., and Suter, J.R., 1988, Transgressive depositional systems of the Mississippi Delta plain: A model for barrier shoreline and shelf sand development: Journal of Sedimentary Research, v. 58, no. 6, p. 932-949.

Penland, S., Connor, P.F., Beall, A., Fearnley, S., and Williams, S.J., 2005, Changes in Louisiana's shoreline: 1855-2002: Journal of Coastal Research, Special Issue No. 44, p. 7-39.

Penland, S., Connor, P.F., Cretini, F., and Wesphal, K.A., 2003, CWPPRA Adaptive Management: Assessment of five barrier island restoration projects in Louisiana: Report Submitted to Louisiana Department of Natural Resources, Office of Coastal Restoration and Management, Baton Rouge, Louisiana, 96 p.

Penland, S., Connor, P., Cretini, F., and Westphal, K., 2004, CWPPRA Adaptive Management: Assessment of five barrier island restoration projects in Louisiana: Pontchartrain Institute for Environmental Sciences, University of New Orleans, New Orleans, Louisiana, 15 p.

Penland, S., and Ramsey, K.E., 1990, Relative sea-level rise in Louisiana and the Gulf of Mexico: 1908-1988: Journal of Coastal Research, v. 6, no. 2, p. 323-342.

Penland, S., and Suter, J.R., 1989, Geomorphology of the Mississippi River Chenier Plain: Marine Geology, v. 90, p. 231-258.

Poirrier, M.A., and Handley, L.R., 2007, Chandeleur Islands, in Handley, L, Altsman, D., and DeMay, R., eds., Seagrass status and trends in the northern Gulf of Mexico-1940-2002: U.S. Geological Survey Scientific Investigations 
BICM Program Summary Report: Data and Analyses 2006 through 2010

Report, 2006-5287, p. 62-71.

Reed, D., 2009, Planning for the future of the Pontchartrain coast: Journal of Coastal Research, Special Issue No. 54, p. 198-205.

Reed, D., Commagere, A., and Hester, M., 2009, Marsh elevation response to Hurricanes Katrina and Rita and the effect of altered nutrient regimes: Journal of Coastal Research, Special Issue No. 54, p. 166-173.

Reed, D.J., 1995, Status and trends of hydrologic modification, reduction in sediment availability and habitat loss/ modification in the Barataria-Terrebonne estuarine system, 752 p. (Also available at http://www.btnep.org/Libraries/ Reports/Status_and_Trends_of_Hydrologic_Modification_Reduction_in_Sediment_Availability_and_Habitat_Loss_ and_Modification.sflb.ashx.)

Resio, D.T., and Westerink, J.J., 2008, Modeling the physics of storm surges: Physics Today, v. 61, no. 9, p. 33-38.

Reyes, E., Georgiou, I., Reed, D., and McCorquodale, A., 2005, Using models to evaluate the effects of barrier islands on estuarine hydrodynamics and habitats: A numerical experiment: Journal of Coastal Research, Special Issue No. 44, p. $176-185$.

Ritchie, W., and Penland, S., 1988, Rapid dune changes associated with overwash processes on the deltaic coast of south Louisiana: Marine Geology, v. 81, p. 97-122.

Roberts, H.H., 1997, Dynamic changes of the Holocene Mississippi River delta plain: The delta cycle: Journal of Coastal Research, v. 13, no. 3, p. 605-627.

Roberts, H.H., Bailey, A., and Kuecher, G.J., 1994, Subsidence in the Mississippi River Delta-Important influences of valley filling by cyclic deposition, primary consolidation phenomena, and early diagenesis: Gulf Coast Association of Geological Societies Transactions, v. 44, p. 619-629.

Roberts, H.H., Walker, N., Cunningham, R., Kemp, G.P., and S. Majersky, 1997, Evolution of sedimentary architecture and surface morphology: Atchafalaya and Wax Lake Deltas, Louisiana (1973-1994): Gulf Coast Association of Geological Societies Transactions, v. 67, p. 477-484.

Rogers, B., and Kulp, M.A., 2009, Late Holocene chronology, origin, and evolution of the St. Bernard Shoals, northern Gulf of Mexico, USA: Geo-Marine Letters, v. 29, no. 6, p. 379-394.

Sallenger, A.H., Jr., 2000, Storm impact scale for barrier islands: Journal of Coastal Research, v. 16, no. 3, p. 890-895.

Sallenger, A.H., Jr., List, J.H., Jaffe, B.E., Penland S., and Williams, S.J., 1992, Regional coastal erosion research and beach preservation, in New directions in beach management: Proceedings, 5th Annual National Conference on Beach Preservation Technology, St. Petersburg Hilton \& Towers, St. Petersburg, Florida, p. 115-134.

Sallenger, A.H., Jr., and Williams, S.J., 1989, U.S. Geological Survey studies of Louisiana barrier island erosion and wetland loss: An interim report of status and results: U.S. Geological Survey Open-File Report 89-0372, 16 p.

Sallenger, A.H., Jr., Wright, C.W., Howd, P., Doran, K., and Guy, K., 2009, Extreme coastal changes on the Chandeleur Islands, Louisiana, during and after Hurricane Katrina, in Lavoie, D., ed., Sand resources, regional geology, and coastal processes of the Chandeleur Islands coastal system-An evaluation of the Breton National Wildlife Refuge: U.S. Geological Survey Scientific Investigations Report 2009-5252, p. 27-36. (Also available at http://pubs.usgs.gov/ sir/2009/5252/.)

Sallenger, A.S., Wright, C.W., and Lillycrop, J., 2007, Coastal change impacts during Hurricane Katrina<an overview, in Kraus, N.C., and Rosati, J.D., eds., Coastal sediments '07: Reston, Virginia, America Society of Civil Engineers, p. $888-896$.

Salvador, A., 1991, Origin and development of the Gulf of Mexico Basin, in Salvador, A., ed., The Gulf of Mexico Basin: Geological Society of America, The Geology of North America, v. J., Boulder, Colorado, p. 389-444. 
Shamban, A.J., 1985, Historical evolution, morphology, and processes of Barataria Pass, Louisiana: Louisiana State University, Baton Rouge, Louisiana, M.S. thesis, 320 p.

Stewart, S.R., 2006, Tropical cyclone report Hurricane Cindy 3-7 July 2005: National Hurricane Center, Miami, Florida, 21 p. (Also available at http://www.nhc.noaa.gov/pdf/TCR-AL032005_Cindy.pdf.)

Steyer, G.D., Raynie, R.C., Stellar, D.L., Fuller, D., and Swenson, E., 1995, Quality management plan for coastal wetlands planning, protection, and restoration act monitoring program: Open-File Series No. 95-01, Louisiana Department of Natural Resources, Coastal Restoration Division, Baton Rouge, Louisiana, 97 p.

Steyer, G.D., Sasser, C.E., Visser, J.M., Swenson, E.M., Nyman, J.A., and Raynie, R.C., 2003, A proposed coast-wide reference monitoring system for evaluating wetland restoration trajectories in Louisiana: Environmental Monitoring and Assessment, v. 81, p. 107-117.

Steyer, G.D., and Stewart, R.E., Jr., 1992, Monitoring program for coastal wetlands planning, protection, and restoration act projects: U.S. Fish and Wildlife Service, National Wetlands Research Center Open-File Report 93-01, 85 p.

Stone, G., and Orford, J., 2004, Storms and their significance in coastal morpho-sedimentary dynamics: Marine Geology, v. 210 , no. $1-4$, p. $1-362$.

Stone, G.W., Zhang, X., and Sheremet, A., 2005, The role of barrier islands, muddy shelf, and reefs in mitigating the wave field along coastal Louisiana: Journal of Coastal Research, Special Issue No. 44, p. 40-55.

Suter, J.R., Berryhill, H.L., Jr., and Penland, S., 1987, Late Quaternary sea-level fluctuations and depositional sequences, southwest Louisiana continental shelf, in Nummedal, D., Pilkey, O.H., and Howard, J.D., eds., Sea-level fluctuation and coastal evolution: Society of Economic Paleontologists and Mineralogists, Special Publication 41, Tulsa, Oklahoma, p. 199-219.

Suter, J., Penland, S., and Ramsey, K., 1991, Nearshore sand resources of the Mississippi River delta plain: Marsh Island to Sandy Point, Louisiana: Louisiana Geological Survey Coastal, Baton Rouge, Louisiana Geology Technical Report No. 8,130 p.

Suter, J., Penland, S., Williams, S., and Kindinger, J., 1988, Stratigraphic evolution of Chandeleur Islands, Louisiana: Gulf Coast Association of Geological Societies Transactions, v. 72, no. 9, p. 1124-1125.

Törnqvist, T.E., Kidder, T.R., Autin, W.J., van der Borg, K., de Jong, A.F.M., Klerks, C.J.W., Snijders, E.M.A., Storms, J.E.A.,van Dam, R.L., Wiemann, M.C., 1996, A revised chronology for Mississippi River subdeltas, Science, v. 273, no. 5282, p. 1693-1696.

Troutman, J.P., Lee, D.M., Khalil, S.M., Carter, B.S., Gray, K.S., and Reynolds, L.A., 2003, Draft barrier-island comprehensive monitoring program (BICM): Louisiana Department of Natural Resources Coastal Restoration Division Biological Monitoring Section, New Orleans, Louisiana, 12 p.

Twichell, D., Pendleton, E., Baldwin, W., and Flocks, J., 2009a, Geologic mapping of distribution and volume of potential resources, in Lavoie, D., ed., Sand resources, regional geology, and coastal processes of the Chandeleur Islands coastal system-An evaluation of the Breton National Wildlife Refuge: U.S. Geological Survey Scientific Investigations Report 2009-5252, p. 150-196. (Also available at http://pubs.usgs.gov/sir/2009/5252/.)

Twichell, D., Pendleton, E., Baldwin, W., and Flocks, J., 2009b, Subsurface control on seafloor erosional processes offshore of the Chandeleur Islands, Louisiana: Geo-Marine Letters, v. 29, p. 348-358.

U.S. Army Corps of Engineers (USACE), 2004, Louisiana Coastal Area (LCA): Louisiana Ecosystem Restoration Study, Final Report, New Orleans, Louisiana, 344 p.

U.S. Army Corps of Engineers (USACE), 2010, Louisiana Coastal Area (LCA), Louisiana beneficial use of dredged material program: Final Programmatic Study Report and Environmental Impact Statement, New Orleans, Louisiana, $192 \mathrm{p}$. 
BICM Program Summary Report: Data and Analyses 2006 through 2010

van Andel, T.H., 1960, Sources and dispersion of Holocene sediments, northern Gulf of Mexico, in Shepard, F.P., Phleger, F.B., and van Andel, T.H., eds., Recent sediments, northwestern Gulf of Mexico: American Petroleum Institute, Tulsa, Oklahoma, Project 51, 394 p.

van Andel, T.H., and Poole, D.M., 1960, Sources of recent sediments in the northern Gulf of Mexico: Journal of Sedimentary Petrology, v. 30, p. 910-922.

van Heerden, I.L., and Roberts, H.H., 1988, Facies development of Atchafalaya Delta, Louisiana: A modern bayhead delta: American Association of Petroleum Geologists Bulletin, v. 72, p. 439-453.

van Maren, D.S., Hoekstra, P., and Hoitink, A.J.F., 2004, Tidal flow asymmetry in the diurnal regime: bed-load transport and morphologic changes around the Red River Delta: Ocean Dynamics, v. 54, p. 424-434.

Walton, T.L., and Adams, W.D., 1976, Capacity of inlet outer bars to store sand: American Society of Civil Engineers, Proceedings, 15th Coastal Engineering Conference, Honolulu, Hawaii, p. 1919-1937.

Westphal, K.A., 2008, Louisiana barrier-island comprehensive monitoring program (BICM) - Volume 1: Barrier shoreline post-storm assessment, Part 3: 2005-2007 photo pairs: Prepared for the Louisiana Department of Natural Resources, Coastal Restoration Division by the University of New Orleans, Pontchartrain Institute for Environmental Sciences, New Orleans, Louisiana, 27 p.

Westphal, K.A., 2009, Louisiana barrier-island comprehensive monitoring program (BICM) - Volume 1: Barrier shoreline post-storm assessment, Part 1: 2005 Post Hurricanes Katrina and Rita photography: Prepared for the Louisiana Department of Natural Resources, Coastal Restoration Division by the University of New Orleans, Pontchartrain Institute for Environmental Sciences, New Orleans, Louisiana, 59 p.

Westphal, K.A., and Penland, S., 2009, Louisiana barrier-island comprehensive monitoring program (BICM) - Volume 1: Barrier shoreline post-storm assessment, Part 2: 2006/2007 aerial survey photography: Prepared for the Louisiana Department of Natural Resources, Coastal Restoration Division by the University of New Orleans, Pontchartrain Institute for Environmental Sciences, New Orleans, Louisiana, 229 p.

Westphal, K.A., Penland, S., Weathers, D., and Paulsell, R., 2009, Louisiana barrier-island comprehensive monitoring program (BICM) - Volume 1: Barrier-shoreline post-storm assessment: Part 5: 2006/2007 aerial video survey: Prepared for the Louisiana Department of Natural Resources, Coastal Restoration Division by the University of New Orleans, Pontchartrain Institute for Environmental Sciences, New Orleans, Louisiana, 35 p.

Wicker, K.M., 1980, Mississippi deltaic plain region ecological characterization: A habitat mapping study: A user's guide to the habitat maps: Final report by the U.S. Fish and Wildlife Service for the U.S. Department of the Interior, Bureau of Land Management Gulf of Mexico OCS Office, New Orleans, Louisiana, FWS/OBS-79/07, Contract no. 14-120001-29085, $76 \mathrm{p}$.

Wicker, K.M., 1981, Chenier plain region ecological characterization: A habitat mapping study: A user's guide to the habitat maps: Louisiana Department of Natural Resources, Baton Rouge, Louisiana, 122 p.

Williams, J.S., Flocks, J., Jenkins, C., Khalil, S., and Moya, J., 2012, Offshore sediment character and sand resource assessment of the northern Gulf of Mexico, Florida to Texas: Journal of Coastal Research, v. 60, p. 30-44.

Williams, S., Penland, S., and Sallenger, A., Jr., eds., 1992, Appendix A: Louisiana’s Hurricane history, in Louisiana barrier-island erosion study: Atlas of shoreline changes in Louisiana from 1853 to 1989: U.S. Geological Survey Miscellaneous Investigations Series I-2150-A, 98 p.

Yu, S., Törnqvist, T.E., and Hu, P., 2012, Quantifying Holocene lithospheric subsidence rates underneath the Mississippi Delta: Earth and Planetary Science Letters, v. 331, p. 21-30.

Zervas, C., 2001, Sea level variations of the United States 1854-1999: National Oceanic and Atmospheric Administration (NOAA) National Ocean Service, NOAA technical report NOS CO-OPS 36, Silver Spring, Maryland, 80 p. 